\title{
Green Public Procurement
}

\section{Legal Instruments for Promoting Environmental} Interests in the United States and European Union

\author{
Jason J. Czarnezki
}

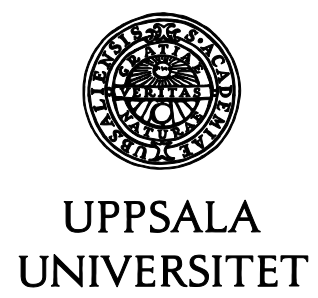


Dissertation presented at Uppsala University to be publicly examined in Lewinsalen, Östra Ågatan 19, Uppsala, Friday, 13 December 2019 at 10:15 for the degree of Doctor of Laws. The examination will be conducted in English. Faculty examiner: Associate Professor Katerina Mitkidis (Department of Law, Aarhus University, Denmark).

\begin{abstract}
J. Czarnezki, J. 2019. Green Public Procurement. Legal Instruments for Promoting Environmental Interests in the United States and European Union. 187 pp. Uppsala: Uppsala University. ISBN 978-91-506-2789-3.

While public environmental law, regulation and governance have paved the traditional road towards environmental and natural resource protection, the pathway has been expanded to include a broader orbit of interest areas and regulatory tools in an effort to achieve sustainability. Through the lens of comparative law and policy, this thesis evaluates one such expansion of environmental law - attempts to further environmental interests through public procurement in the European Union (EU) and United States (U.S.).

Green public procurement (GPP) means that when public institutions are procuring goods and services they take into account environmental costs and benefits along a product's life cycle, with the goal of contributing to sustainable consumption and production. A product's life cycle includes the extraction of raw materials used to make the good, production and manufacturing, packaging, distribution, use, and disposal. Environmental externalities arise during a product's life cycle that current purchase prices simply do not reflect.

The aim of this thesis is to consider the space, implementation, and value of environmental requirements in public procurement, and evaluate to what extent environmental law and GPP can influence legal norms and policies promoting internal market harmonization and free market competition in the U.S. and EU. Put more succinctly, the aim is to determine the size and scope of the space for GPP in the U.S. and EU.
\end{abstract}

Keywords: environmental law, procurement law, green public procurement, sustainable public procurement, eco-labels, life-cycle costing, comparative law, Public Sector Directive 2014/24/EU, neoliberal regulation, sustainability, private environmental governance, public procurement, market participant exception, commerce clause, dormant commerce clause

Jason J. Czarnezki, Department of Law, Box 512, Uppsala University, SE-75120 Uppsala, Sweden.

(C) Jason J. Czarnezki 2019

ISBN 978-91-506-2789-3

urn:nbn:se:uu:diva-393820 (http://urn.kb.se/resolve?urn=urn:nbn:se:uu:diva-393820) 


\section{Contents}

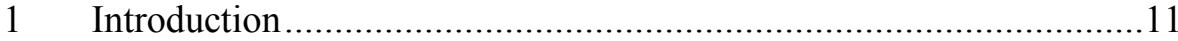

1.1 Aim and Research Questions ................................................11

1.2 Green Public Procurement as Neoliberal Regulation .................14

1.3 Roadmap and Organizational Structure ....................................15

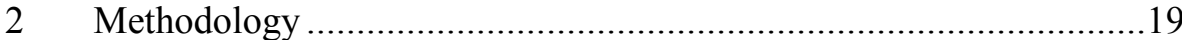

2.1 Introduction to Methods Used and Points of Comparison .........19

2.2 The Comparative Law Approach and Global

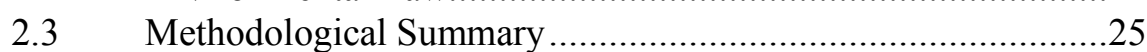

3 What is Green Public Procurement? ...............................................27

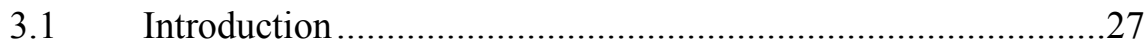

3.2 Environmental Regulatory Approaches ..................................27

3.3 Defining Green Public Procurement............................................33

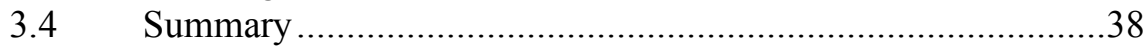

4 Comparing the U.S. and EU Legal Systems ……..............................40

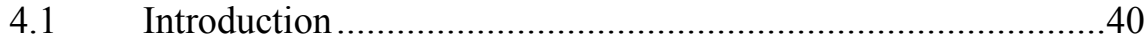

4.2 Legal and Governmental Structures ........................................40

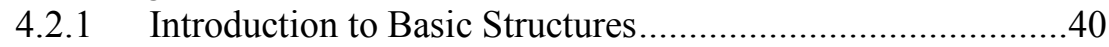

4.2.2 Government Structure of the U.S.........................................4

4.2.3 Government Structure of the EU............................................44

4.3 The Legal Basis for Public Procurement Law .............................51

4.4 The Tender Process......................................................................54

4.4.1 Procurement Roles in the U.S and EU ...............................54

4.4.2 Tender Processes in the U.S..............................................54

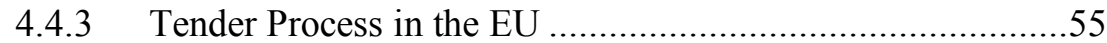

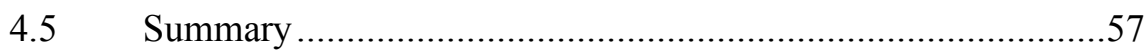

5 The Economic Power of Green Public Procurement ............................59

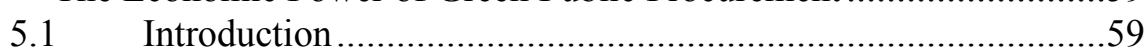

5.2 The Economic Power of U.S. Public Procurement.....................59

5.3 The Economic Power of EU Public Procurement .......................61

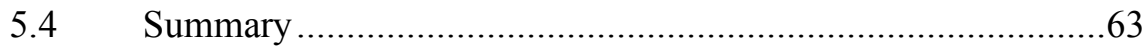


6 The U.S. Market Participant Exception, Public Procurement \& The

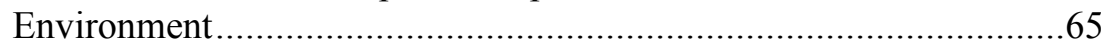

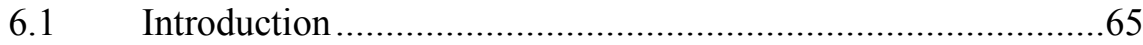

6.2 What is the Market Participant Exception? ...............................67

6.2.1 Introduction to Legal Basis for Market Participant

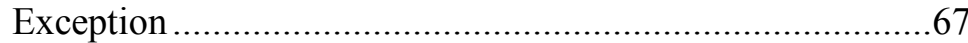

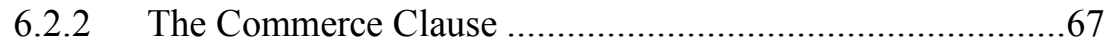

6.2.3 The Dormant Commerce Clause ..........................................69

6.2.4 The Market Participant Exception..........................................73

6.3 The Environment, Food \& the Market Participant Exception....76

6.4 Generally Applicable Environmental Standards and

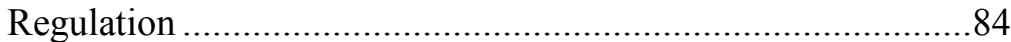

6.5 Preemption Doctrine: An Additional Factor When States

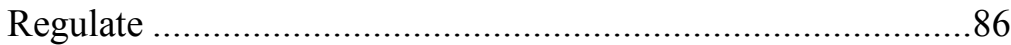

6.6 Green Public Procurement by the U.S. Federal Government.....88

6.7 Green Public Procurement by American States.........................95

6.7.1 Framework Categories for U.S. Green Public Procurement ..95

6.7.2 Environmentally Preferable Products and Life-Cycle

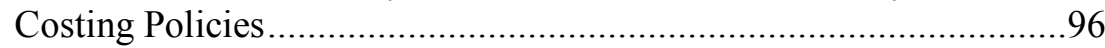

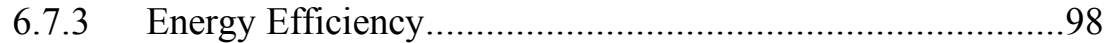

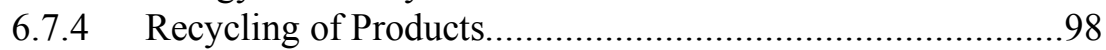

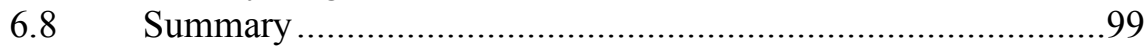

7 EU Public Procurement and Environmental Interests........................100

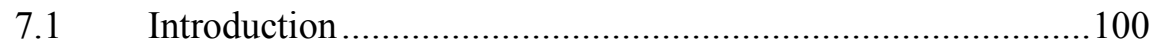

7.2 EU Public Procurement Law ..................................................100

7.2.1 Framework for EU Procurement Law Analysis..................100

7.2.2 CJEU Case Law Builds the Foundation for the 2014 Public Procurement Reform ......................................................101

7.2.3 EU Public Procurement Law Prior to the 2014 Public Procurement Reform .....................................................106

7.2.4 Comparing EU and U.S. Law as it Relates to the Market Participant Exception and Environmental Considerations in Public Procurement .........................................................116

7.3 The 2014 Public Sector Directive and Green Public

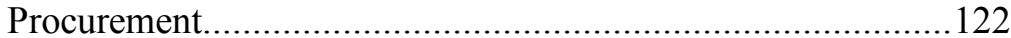

7.3.1 Public Procurement Reform of 2014 .................................122

7.3.2 The Details of the 2014 Public Sector Directive..................123

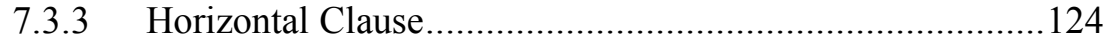

7.3.4 Linked to the of Subject of the Contract Requirement........125

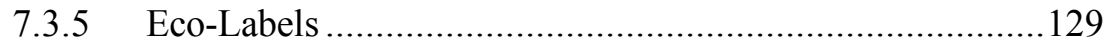

7.3.6 Life-Cycle Costing ...........................................................131

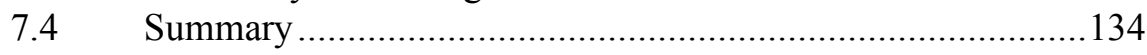


8 Green Public Procurement Implementation in the EU with Sweden

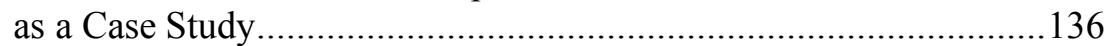

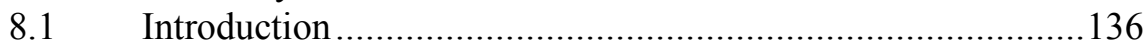

8.2 Implementation of the 2014 Public Sector Directive................137

8.2.1 General Implementation Challenges .................................137

8.2.2 National Implementation in Sweden ..................................138

8.3 The Role of the Swedish National Procurement Agency..........141

8.4 The Role of the EU in Standardizing Implementation..............143

8.5 The Challenges of Local Green Public Procurement

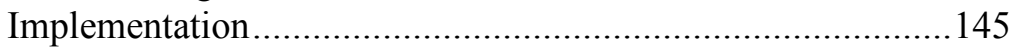

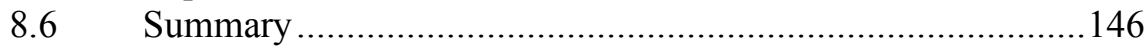

9 The Future of Green Procurement: Life-Cycle Costing and Eco-

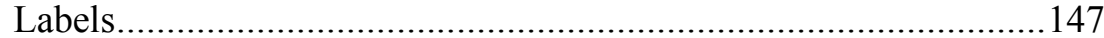

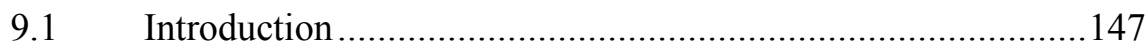

9.2 Life-Cycle Costing and Impact Valuation .............................150

9.2.1 Life-Cycle Costing and the 2014 Public Sector Directive...150

9.2.2 What is Life-Cycle Costing?............................................151

9.2.3 Life-Cycle Costing Methodologies .....................................154

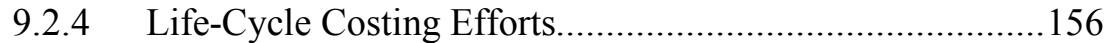

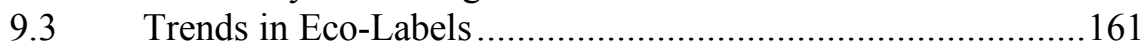

9.3.1 Introduction to Eco-Labels and Procurement .......................161

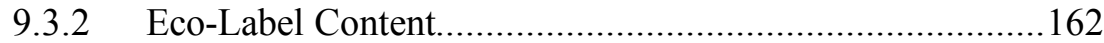

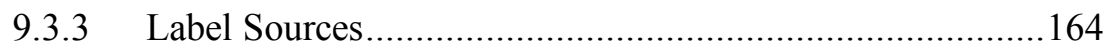

9.3.4 Integrating Life-Cycle Costing into Eco-Label Criteria .......166

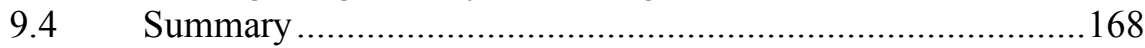

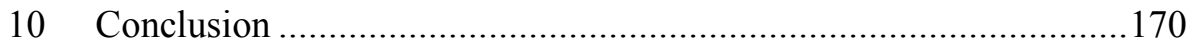

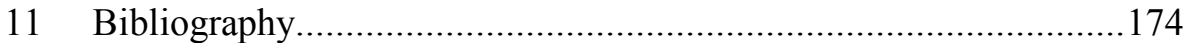

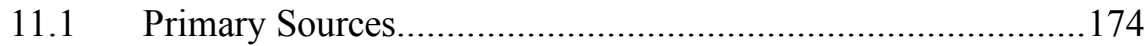

11.2 Secondary Sources (in alphabetical order).............................180 



\section{Sammanfattning på svenska}

Lagstiftning samt annan reglering och styrning inom miljöområdet banade den traditionella vägen för skyddet av miljön och naturresurserna. Parallellt med detta har det också skett en utveckling av andra regleringsinstrument och intresseområden i syfte att uppnå hållbarhet. Denna avhandling undersöker en sådan utvidgning genom att anamma ett komparativt perspektiv på miljörätt och policy - närmare bestämt hur miljöintressen kan främjas i offentlig upphandling inom Europeiska unionen (EU) och i USA.

Grön offentlig upphandling (eng. green public procurement, GPP) innebär att offentliga institutioner tar hänsyn till miljöpåverkan längs en varas eller tjänsts livscykel vid upphandling. Det görs för att bidra till hållbar konsumtion och produktion. En varas eller tjänsts livscykel innefattar utvinning av råvaror, produktion, förpackning, distribution, användning och bortskaffande. Olika externa miljöeffekter uppstår alltså under livscykeln, men de reflekteras inte alltid i produktens eller tjänstens pris.

Syftet med avhandlingen är att undersöka utrymmet för och införandet av miljökrav i offentlig upphandling samt det miljömässiga värdet av att sådana krav ställs. Därutöver diskuteras i vilken utsträckning miljölagstiftning och GPP kan påverka de juridiska normer och den policy som syftar till att främja harmonisering av den inre marknaden och den fria konkurrensen i USA och EU. Sammanfattningsvis är syftet således att fastställa vilket utrymme som GPP ges i USA och EU, dels på central nivå (federal-/EU-nivå), dels på statlig nivå (delstatsnivå i USA/medlemsstatsnivå inom EU). 


\section{Acknowledgments}

I wish to especially thank my dissertation supervisors Jan Darpö (Uppsala Universitet) and Roberto Caranta (University of Turin) - without their efforts this project would not have been possible - as well as Gabriel Michanek, who first introduced me to the Uppsala University Faculty of Law. I also wish to thank my current and former colleagues at Uppsala University, Maria Bergström, Maria Cicilaki, Nathalie Elenius, Yaffa Epstein, Maria Forsberg, Agnes Hellner, Henrik Josefsson, Annika Nilsson, Mosa Sayed, Emily Stein, and Charlotta Zetterberg; my colleagues and students at Pace University, Melanie DuPuis, Kat Fiedler, Rosemarie Hebner, Deborah Heller, Laura Jensen, Sarah Main, Anthony Mazza, Colin Myers, Sara O'Shea, and Margot Pollans, as well as Sarah Light, Carrie Scrufari and the many others who provided feedback and assistance on drafts of this thesis. I sincerely appreciate the many helpful comments received at faculty workshops at Pace and seminars at Uppsala, as well as presentations at Oxford University, University of Oslo, University of Ghent, Vermont Law School, University of Turin, University of Copenhagen, Stockholm University, and Swedish Institute for European Policy Studies.

I appreciate the helpful information provided by individuals at the Swedish Environmental Protection Agency, the Swedish National Agency for Public Procurement, SKL Kommentus, and universities throughout Europe, including Marta Andhov, Margareta Bergh, Carol Cravero, Annika Kleen, Steven Lord, Stefan Lund, Peter Nohrstedt, Sven-Olof Ryding, Dagne Sabockis, Heini-Marja Suvilehto, and especially Jörgen Hettne, who served as a thoughtful, thorough and excellent disscusant at my end seminar. I wish to thank the Uppsala Forum on Democracy, Peace, and Justice, Uppsala University Faculty of Law, and Elisabeth Haub School of Law at Pace University.

Finally, I thank my Swedish families, the Thorens, the Lunds, and the Ulmestigs and my family - my spouse Andrea Voyer, my daughters Hazel and Lauretta, and our tiny dogs Zelda Jane and Daisy. 


\section{List of Abbreviations}

carbon dioxide $\left(\mathrm{CO}_{2}\right)$

Comprehensive Procurement Guideline (CPG)

Court of Justice of the European Union (CJEU)

environmental life-cycle costing (E-LCC)

environmental product declarations (EPDs)

environmentally preferable purchasing (EPP)

Executive Order (EO)

European Parliament (EP)

European Union (EU)

Federal Acquisition Regulation (FAR)

Federal Courts Improvement Act of 1982 (FCIA)

General Administrative Services (GSA)

Government Accountability Office (GAO)

green public procurement (GPP)

gross domestic product (GDP)

International Reference Life Cycle Data System (ILCD)

Life cycle assessment (LCA)

life-cycle costing (LCC)

linked to the subject matter of the contract (LtSC)

Material Input Per Service Unit (MIPS)

most economically advantageous tender (MEAT)

New Jersey (NJ)

New Jersey Army National Guard (NJARNG)

New Jersey Department of Military and Veterans Affairs (DMAVA)

nitrous oxide $\left(\mathrm{NO}_{\mathrm{x}}\right)$

non-methane hydrocarbons (NMHC)

Official Journal of the European Union (OJEU)

prior information notice (PIN)

Procurement of Innovation (PPI)

Product Environmental Footprint (PEF)

Radio-Frequency Identification (RFID)

SKLKommentusInköpscentral (SKI)

small and medium sized enterprises (SMEs)

sustainable public procurement (SPP)

Swedish Environmental Management Council (SEMCO)

Swedish National Agency for Public Procurement (SvNPA) 
Tenders Electronic Daily (TED)

Treaty on European Union (TEU)

Treaty on the Functioning of the European Union (TFEU)

United Nations Office for Project Services (UNOPS)

United States of America (U.S.)

United States Department of Agriculture (USDA)

United States Environmental Protection Agency (EPA) 


\section{Introduction}

\subsection{Aim and Research Questions}

While public environmental law, regulation and governance have paved the traditional road towards environmental and natural resource protection, the pathway has been expanded to include a broader orbit of interest areas and regulatory tools in an effort to achieve sustainability. Through the lens of comparative law and policy, this thesis evaluates one such expansion of environmental law-attempts to further environmental interests through public procurement in the European Union (EU) and United States (U.S.).

Green public procurement (GPP) means that when public institutions are procuring goods and services, they take into account environmental costs and benefits along a product's life cycle, with the goal of contributing to sustainable consumption and production. ${ }^{1}$ A product's life cycle includes the extraction of raw materials used to make the good, production and manufacturing, packaging, distribution, use, and disposal. Externalities arise during a product's life cycle that current purchase prices simply do not reflect. Purchase prices fail to incorporate indirect supply chain costs such as environmental externalities. Hence, life-cycle costing (LCC), in its fullest form, attempts to measure and monetize these externalities.

GPP, which can employ LCC tools, attempts to serve as an effective environmental regulatory tool and alternative form of environmental governance beyond the traditional public law model. GPP enables public institutions to create both public and private markets for more environmentally friendly goods, creating a model for environmental progress that bridges the gap between traditional environmental $\mathrm{law}^{2}$ and private environmental governance. ${ }^{3}$ GPP and the tools it employs offer a unique model within the now prevalent

\footnotetext{
${ }^{1}$ Hans Christian Bugge \& Christina Voigt, Sustainable Development in International and National Law (Europa Law Publishing 2008) 425.

${ }^{2}$ Richard J Lazarus, The Making of Environmental Law (Chicago 2004); James Salzman, 'Teaching Policy Instrument Choice in Environmental Law: The Five P's' (2013) 23 Duke Environmental L and Policy Forum 363.

${ }^{3}$ Michael P Vandenbergh, 'Private Environmental Governance' (2013) 99 Cornell L Rev 129; Sarah E Light and Eric W Orts, 'Parallels in Public and Private Environmental Governance' (2015) 5 Michigan J of Environmental and Administrative L 1; Michael P Vandenbergh and Jonathan M Gilligan, Beyond Politics: The Private Governance Response to Climate Change (Cambridge University Press 2017).
} 
"neoliberal" approach to environmental regulation. This neoliberal approach uses public regulation to influence, primarily voluntarily, consumer behavior and corporate actions in the market and has begun to overshadow the traditional and formal role of public environmental law in demanding behavioral change. ${ }^{4}$

In the U.S., American states can engage in GPP by taking advantage of the "market participant exception" to the U.S. Constitution's Commerce Clause which permits public institutions to make purchasing decisions and prefer product characteristics as if they were individual consumers. The federal government, through executive action, and states and municipalities, through both executive action and legislation, have also begun to promote more sustainable purchasing. In the EU, Public Sector Directive 2014/24/EU, part of the EU procurement reforms of 2014, empowers public contracting authorities to engage in green procurement by including eco-label criteria in public tender offers and by taking into account life-cycle costs.

The aim of this thesis is to consider the space, implementation, and value of environmental requirements in public procurement, and evaluate to what extent environmental law and green public procurement can influence legal norms and policies promoting internal market harmonization and free market competition in the U.S. and EU. Put more succinctly, the aim is to determine the size and scope of the space for GPP in the U.S. and EU. The problem this thesis addresses is figuring out the contours of this space and how to successfully exist in this space. The research questions below are formulated to achieve this aim.

Thus, this thesis engages two specific research questions in evaluating GPP; the first related to comparative law and the second related to policy implementation. The first question asks whether there is space for GPP, and the second asks, if so, how can the space be employed.

1. What can be learned about the space for GPP from comparing the U.S. and EU legal frameworks and implementation rules, specifically considering the American market participant exception to the Commerce Clause and the 2014 EU Public Sector Directive? In asking this question, perhaps one can determine how, and under what conditions, procurement can best be used to achieve greater sustainability and ecological innovation in markets and supply chains, while also promoting the interests of free competition, innovation, and trade harmonization in internal markets. What is the legal space available to achieve such a balance?

\footnotetext{
${ }^{4}$ Jason J Czarnezki and Katherine Fiedler, 'The Neoliberal Turn in Environmental Regulation' (2016) 2016 Utah L Rev 1.
} 
2. What tools are employed when engaged in GPP? This question addresses the challenges in developing life-cycle costing methodologies and the role of eco-labels and their accompanying criteria, as well as the challenge of ensuring fair competition in the internal market, in an effort to determine whether and how green procurement can be effectively used to promote environmental interests while creating new innovative markets. In other words, what are the best tools and methods available to engage in GPP if there is the legal space?

Understanding the U.S. legal system may be helpful to improving the European Union's GPP program by suggesting opportunities for creativity and flexibility in implementation by the EU Member States. In turn, the EU GPP program, its potentially forthcoming life-cycle costing methodology, and the common eco-label and environmental technical criteria it uses, may serve as models for U.S., as well as global, implementation of GPP.

Important information on how to successfully implement green procurement can be learned by observing the experiences of the EU Member States and other European countries, in particular the work of national procurement agencies like the Swedish National Agency for Public Procurement, and through the true cost accounting ${ }^{5}$ efforts of private businesses that are developing more sustainable supply chains in response to consumer demand and anticipated environmental regulatory reform in the future. In the GPP context, governments of all levels are themselves consumers and often desire to give preferential treatment to products and services with smaller environmental and carbon footprints.

The U.S. government's initial efforts to implement green procurement spurred, what is now pervasive, local and state government action, and green public procurement at the federal level advanced under the Clinton, Bush and Obama Presidential Administrations. ${ }^{6}$ American states and municipalities have significant leeway and sovereignty in their procurement decisions via the "market participant exception" to the Commerce Clause of the U.S. Constitution which permits states to discriminate in purchasing in the same manner as a consumer. ${ }^{7}$

\footnotetext{
${ }^{5}$ The Lexicon of Sustainability defines true cost accounting as "a practice that accounts for all external costs - including environmental, social and economic - generated by the creation of a product." Lexicon of Sustainability, 'True Cost Accounting: The Real Cost of Cheap Food' (Feb 2014) <http://www.pbs.org/food/features/lexicon-of-sustainability-true-cost-accountingthe-real-cost-of-cheap-food/> accessed 7 Mar 2019.

${ }^{6}$ Exec Order No 13,693, Planning for Federal Sustainability in the Next Decade, 80 Fed Reg 15,871 (Mar 25, 2015).

${ }^{7}$ See below Part 6 .
} 
In the European Union, the 2014 Public Sector Directive (2014/24/EU) now permits green public procurement, with questions existing as to how it will be interpreted and implemented over time. ${ }^{8}$ While the U.S model, under the market participant exception, allows environmental and any other criteria to be considered for any reason in the purchasing process, EU law provides, perhaps, less discretion ${ }^{9}$ and prohibits discrimination. The EU permits wholesale adoption and standardization of the GPP process allowing for a greater positive environmental impact in the end. However, GPP reform comes against a historical background of anti-discrimination and market harmonization, preference for lowest cost goods and services regardless of environmental criteria, and challenges of operationalizing a continent-wide methodology that allows for measurement and monetization of environmental externalities. In the EU, Member States are not given the same deference as individual consumers.

In summary, the U.S. may allow for greater experimentation and creativity, but lacks the qualities of standardization and centralization found in Europe. There also remain strong ideological (e.g., views on climate change) and theoretical (e.g., cost-benefit analysis versus precautionary principle) differences on environmental matters between the U.S. and EU.

\subsection{Green Public Procurement as Neoliberal Regulation}

Over the past 30-plus years, environmental regulation and sustainability programs have taken a neoliberal turn, perhaps even becoming the dominant form of environmental governance. For example, cost benefit analysis has certainly come to dominate environmental regulatory policy in the U.S., implemented through agencies such as the White House Office of Budget and Management and Office of Information and Regulatory Affairs. In this context, neoliberalism denotes "forms of political-economic governance premised on the extension of market relationships." ${ }^{10}$ Neoliberal environmental regulation includes

8 The EU passed three procurement directives as part of the 2014 reforms: Directive 2014/23/EU of the European Parliament and of the Council of 26 February 2014 on the Award of Concession Contracts [2014] OJ L94 1 (Concessions Directive); Directive 2014/24/EU of the European Parliament and of the Council of 26 February 2014 on Public Procurement and Repealing Directive 2004/18/EC [2014] OJ L94 65 (Public Sector Directive); and Directive 2014/25/EU of the European Parliament and of the Council of 26 February 2014 on Procurement by Entities Operating in the Water, Energy, Transport and Postal Services Sectors and Repealing Directive 2004/17/EC [2014] OJ L94 23 (Utilities Directive).

${ }^{9}$ For a discussion of the extent of such discrestion, see Sanja Bogojević, Xaview Groussot and Jörgen Hettne (eds), Discretion in EU Public Procurement Law (Hart 2019).

${ }^{10}$ Wendy Larner, 'Neo-liberalism: Policy, Ideology, Governmentality' (2000) 63 Studies in Political Economy 5, 5. 
the use of market-based mechanisms to achieve environmental protection (referred to as "free-market environmentalism"), and information dissemination and regulation (such as labeling and advertising) to influence consumer preferences, as well as the promotion of private environmental governance.

This neoliberal turn in environmental regulation has received much criticism - that progressives have sold out to conservative free-market principles (as opposed to relying on government mandated public health and welfare standards), or that consumers are overwhelmed by the "green choices" provided by consumer brands, or that businesses simply use environmental preferences by consumers to engage in "greenwashing." "11 This neoliberal turn also has its share of supporters-arguing that the approach creates incentives for technological innovation, improves efficiency, and lowers transaction costs by eschewing government mandates in favor of markets and replacing regulatory prohibitions with private property rights. ${ }^{12}$

It can be argued that green public procurement, at least in its current form, is a type of neoliberal regulation as it is a voluntary government program intended to stimulate market innovation. In this way, GPP acts not only in a middle space between public law and private governance in the environmental field, but also in an intermediate space between traditional public environmental mandates and neoliberal reliance on consumers and industry to make the appropriate choices. But should one be comfortable with a neoliberal GPP approach rather than a traditional environmental law approach dictating how goods are produced? GPP may only be a second-best solution, at least in the United States, as compared to direct non-voluntary regulation that can demand changes to limit negative environmental externalities at the production thorough disposal stages of a good's value chain. In the EU, its stronger traditional environmental public law and emerging GPP program may be on equal footing - and it's always better to have and use more tools in the regulatory toolbox. In any event, if sustainable procurement remains in the public interest, should national governments make it mandatory for public institutions?

\subsection{Roadmap and Organizational Structure}

To answer the questions posed by this thesis, one must know more about the framework and implementation of GPP. Again, this thesis considers, through a comparative law lens what can be learned from the U.S. and EU experiences

\footnotetext{
${ }^{11}$ For further discussion, see Jason J Czarnezki, Andrew Homan and Meghan Jeans, 'Creating Order Amidst Food Eco-Label Chaos' (2015) 25 Duke Environmental L and Policy Forum 281, 281.

12 Terry L Anderson and Donald R Leal, Free Market Environmentalism 21-25 (rev edn, Palgrave Macmillan 2001) (explaining the difference between free market and political environmentalism).
} 
with green public procurement; and under what conditions GPP may be effectively used to promote environmental interests while creating new innovative markets, specifically through the use of eco-labels and life-cycle costing.

Part 2 justifies and describes the comparative law and other research methods used in this thesis.

Part 3 of this thesis defines green public procurement and how it fits into the broader matrix of environmental regulation.

Part 4 compares the structure of U.S. and EU legal systems, especially as they relate to procurement law and the public procurement tender process.

Part 5 illustrates the economic power of public procurement in the U.S. and $\mathrm{EU}$, and the ability of government purchasing to influence markets.

Part 6 defines the market participant exception under U.S. law through a discussion of the Commerce Clause of the U.S. Constitution and its counterpart, the judicially created doctrine of the dormant commerce clause, as well as recognizes the authority of the preemption doctrine. It also discusses green public procurement in the American federal and state governments.

Part 7 discusses traditional EU public procurement law and its relationship to the consideration of environmental factors, and analyzes the tools found in the 2014 Public Sector Directive that allow EU Members states to employ when purchasing such as life-cycle costing and eco-labels. It continues by addressing the dominant legal and policy question in comparing U.S. and EU law as it relates to public procurement, geographic restrictions, and the environment: whether it is better (and lawful) to create general environmental standards or allow a market participant exception in public procurement to achieve ecological goals (though these options may not be mutually exclusive).

Scholars, prior to the passage of EU public procurement reform, vigorously debated how the CJEU should and would interpret the new procurement rules, then at the proposal stage, in light of primary law. ${ }^{13}$ And large-scale U.S. approaches to GPP are in their infancy. Thus, there is no ongoing comparative legal research on public procurement as a means for promoting environmental interests.

\footnotetext{
13 Jörgen Hettne, 'Strategic Use of Public Procurement - Limits and Opportunities' (2013) 7 SIEPS 1; Jörgen Hettne, 'Legal Analysis of the Possibilities of Imposing Requirements in Public Procurement that Go Beyond the Requirements of EU Law' (2013) 6 Upphandlingsutredningen (Legal Analysis); Roberto Caranta, On Jörgen Hettne's Legal Analysis of the Possibilities of Imposing Requirements in Public Procurement that Go beyond the Requirements of EU Law; and Peter Kunzlik, Comment on Professor Jörgen Hettne's Paper, 'Legal Analysis of the Possibilities of Imposing Requirements in Public Procurement that Go beyond the Requirements of EU Law, 'and Professor Roberto Caranta's Commentary in Annex 12 to the Official Report of the Swedish Government 2013:12, "Goda affärer - en strategi för hållbar offentlig upphandling" (SOU 2013:12) <https://www.regeringen.se/49bb50/contentassets/94e3a7f86d2f4784b126e16c6f4ec3a4/bilagedel-3-sou-201312>.
} 
Part 8 , as a case study, analyzes implementation of green public procurement in Sweden from its creation of the National Agency for Public Procurement to the current challenges faced by municipalities.

Part 9 considers two key components of the evolution of green public procurement - first, the development of life-cycle costing methodologies ${ }^{14}$ and, second, the emergence of eco-labeling criteria - as requirements for products to meet public procurement standards. Part 9 discusses whether these methodologies and standards will be created by private business, government entities or third-party certifiers, as well as offers thoughts on whether GPP requirements can lead to new markets for certifying agencies and re-define the share of eco-friendly goods in some markets.

The Conclusion of this thesis, first, notes that the emergence of green public procurement has already led to improved measurement tools in evaluating environmental externalities within supply chains, as well as changes in business practices. The question going forward is whether green public procurement, given the 2014 EU Public Sector Directive, its broad economic power and scope, and increased market demand for environmentally friendly products, can lead to greater product innovation, and ultimately real environmental change.

Second, the initial value of any GPP legislation is in making it clear to contracting authorities, and not subject to legal ambiguity, that they can pursue green public procurement. However, neoliberalism may only be a secondbest solution where direct regulation of environmental externalities along product supply changes remains politically and practically feasible.

Third, the costs of environmentally friendly goods are high, as are the informational burden of GPP and the costs of its implementation. Thus, national/EU law in Europe and state/federal law in the U.S. should consider making GPP mandatory to lower the price of eco-friendly products, reduce the data gathering costs of GPP, and help create standardized processes for municipalities to engage in effective GPP.

Fourth, green public procurement in the U.S. and EU may be more effectively used to promote environmental interests while creating new innovative markets if the two jurisdictions can learn from each other. The U.S. legal system can be helpful to the EU in designing its GPP program in terms of suggesting opportunities for creativity and flexibility. And ultimately the EU GPP program, its perhaps forthcoming life-cycle costing methodology, and the common eco-label environmental technical criteria it uses may be a model for U.S., and global, implementation.

\footnotetext{
${ }^{14}$ For an in-depth discussion and definition of life-cycle costing, see Jason J Czarnezki and Steven Van Garsse, 'What is Life Cycle Costing?' in Marta Andhov, Roberto Caranta, Anja Wiesbrock (eds), Cost and EU Public Procurement Law: Life-Cycle Costing for Sustainability (Routledge 2019).
} 
Fifth, and finally, due to the data and information intensity of life-cycle costing and calculating environmental footprints of goods and services, it is challenging to convey this information to individual and institutional consumers. Conveying such information could occur along any number of paths. There could be a merger of LCC information into more simplified eco-labels that will be able to be explicitly used in the public procurement process. This may lead public authorities to require specific eco-labels (rather than only their technical criteria), as well as the modification of the "linked to the subject matter of the contract" requirement from the Public Sector Directive as it relates to eco-labels. The data could be incorporated, by businesses themselves, into their brand identity whereby consumers and producers avoid the proliferation of eco-labels, and instead consumers buy products based on a brand's environmental identity. While industry may like this evolution, a specific brand could not be required in a public tender process. Perhaps with standardization of measurement tools and externality costs, LCC data can be more effectively included in the price itself. In the end, life-cycle costing data provides society with better information about the true costs of products and services. Knowing which parts and processes of a given product's life cycle creates the most significant environmental externalities may lead us full circle to where these harms will become directly regulated by public law, perhaps ending the neoliberal experiment. 


\section{Methodology}

\subsection{Introduction to Methods Used and Points of Comparison}

In order to analyze and evaluate both the EU and U.S. legal systems as they relate to the law of sustainable and green public procurement, as well as the objectives and implementation of GPP, this thesis relies on traditional doctrinal analysis (as defined in the American context as legal analysis of judicial opinions for inconsistencies, trends, holdings and ambiguities ${ }^{15}$ ), concepts of legal interpretation in both the common and civil law traditions, ${ }^{16}$ the notion of global environmental law, and comparative law methodology (the "essence" of which is "the act of comparing the law of one country to that of another" ${ }^{17}$ ).

To define these concepts further, doctrinal research remains a distinct form of research designed to create greater understanding or address an alleged lack of coherence or normative shortcoming in a defined area of law..$^{18}$ Global environmental law recognizes that environmental law has been internationalized, and is a product of both public and private governance. ${ }^{19}$ Legal interpretation uses tools and canons of statutory construction to understand the meaning of legislation..$^{20}$ And comparative law must take on an even more

\footnotetext{
${ }^{15}$ See Richard A Posner, 'The Present Situation in Legal Scholarship' (1980) 90 Yale LJ 1113.

${ }^{16}$ Richard A Posner, The Problems of Jurisprudence (Harvard 1990); Antonin Scalia, A Matter of Interpretation: Federal Courts and the Law (Princeton 1997); William N Eskridge, Jr, Dynamic Statutory Interpretation (Harvard 1994); John Henry Merryman, The Civil Law Tradition (3d ed, Stanford 2007).

17 Geoffrey Samuel, An Introduction to Comparative Law Theory and Method (Hart 2014); Edward J. Eberle, 'The Method and Role of Comparative Law' (2009) 8 Washington U Global Studies L Rev 451, 452.

${ }^{18}$ Theunis Roux, 'Judging the Quality of Legal Research: A Qualified Response to the Demand for Greater Methodological Rigour’ (2014) 24 Legal Education Rev 177, 186, 204.

${ }^{19}$ Tseming Yang \& Robert V Percival, 'The Emergence of Global Environmental Law' (2009) 36 Ecology LQ 615, 616.

${ }^{20}$ Jason J Czarnezki \& William K Ford, 'The Phantom Philosophy? An Empirical Investigation of Legal Interpretation' (2006) 65 Maryland L Rev 841.
} 
crucial role in an increasingly globalized world. ${ }^{21}$ The comparative law approach is the key choice of method for this thesis, but its use is specifically limited to constitutional and primary law differences between the U.S. and EU in creating the space for green public procurement.

In addressing the research questions, described in detail in Part 1 above, of (1) how differing legal frameworks implement rules and create space for GPP, and (2) what are the challenges of using LCC and ecolabels as tools when there is space for GPP, the U.S. and EU are useful jurisdictions to compare and contrast in their views toward trade harmonization and the market role of government institutions, and their development of eco-labels and LCC methodology. In other words, the comparative method allows for an analysis that attempts to answer why GPP might work better in one jurisdiction and not in another.

This thesis compares U.S. and EU governmental structures (American federalism versus the unique EU structure) to shed light on the concepts of flexibility, centralization, innovation, and autonomy in the GPP context. It also compares the legal principles underlying GPP between the EU and U.S., as well as the practical implementation of GPP at different levels of government within each jurisdiction. These comparisons of government structures, legal frameworks, and implementation issues allow for determination of the nature and type of space for GPP in each jurisdiction, as well as inquiry into what tools can be created and best facilitate GPP.

Using primarily the comparative law method, described in greater detail below, this project specifically addresses the following topics in order to answer the thesis' two research questions regarding the space for and implementation of GPP:

- illustrates the power and scope of public purchasing, and the potential economic influence of green public procurement;

- compares U.S. Commerce Clause constitutional jurisprudence with EU primary law on free trade and internal market harmonization;

- analyzes constitutional differences between the U.S. and EU in their relationships to states/Member States;

- compares American state and federal law, and EU Law and Member State national law and regulations that attempt to influence environmental interests through public procurement;

- analyzes the text and implementation of Directive 2014/24/EU replacing Directive 2004/18/EC, as well as interpretive notes on their meaning provided by the $\mathrm{EU}$;

- engages in a case study of Sweden in particular, as this Scandinavian country has the highest level of green criteria in tender offers

${ }^{21}$ Eberle (n 17) 451; Yang (n 19). 
in the EU and it is home to the unique Swedish National Agency for Public Procurement that has created life-cycle costing tools for government agencies that seek to engage in green public procurement; and

- critically analyzes the means and schemes devised to implement GPP in the U.S and EU, specifically looking at the role of life-cycle costing and ecolabels.

There are many challenges to engaging in comparative law research between the U.S. and EU in the procurement context. However, the jurisdictions' structural and constitutional frameworks, as well as public policy movement towards GPP, provide useful points of comparison.

Differences in the two jurisdictions that present challenges include a lack of significant sustainable public procurement case law in the U.S. compared to the EU, ad hoc and diffuse GPP policy at the American state level, and a lack of coherent U.S. GPP policy action at the federal level versus centralized and acted upon procurement reform by the EU and its Member States, and the differing roles of the public versus private sectors in each jurisdiction. Despite these differences, comparison allows for analysis on how the space for GPP can best be activated and can shed light on effective implementation; for example, in determining the scope of informational barriers, the creation of lifecycle costing methodologies, the roles of eco-labels, and what levels of government can foster GPP.

\subsection{The Comparative Law Approach and Global Environmental Law}

This thesis analyzes the space and implementation of GPP. In other words, it is an attempt to understand what is allowed and required by differing governmental structures and GPP legislation, as well as evaluate its implementation. Again, the comparative law approach is the key choice of method (with its use specifically limited to constitutional and primary law differences between the U.S. and EU). Comparative law can play a larger role in shedding light on and, perhaps, helping solve important public policy questions - inquiries that often transcend national borders. ${ }^{22}$ For example, can and should we use green public procurement rather than or in addition to traditional public environmental law? It is particularly useful to ask such questions in a comparative setting, and it

${ }^{22}$ Eberle (n 17) 454. 
is "well advised" to compare both the similarities and differences when engaged in comparative inquiries ${ }^{23}$; here comparing the United States and the European Union along with the sovereign states and countries that make up this federation and union.

However, while the comparative law method is the primary driver for this thesis, the legal method used, in practice and in theory, is both doctrinal and comparative. Comparative legal research can be best understood as a form of doctrinal research as it focuses on drawing out the lessons that foreign legal systems have to teach, and it is targeted at the construction of legal doctrine in a particular legal system. ${ }^{24}$ Researchers have long used a comparative law approach to examine how various modes of environmental governancethose "means by which society determines and acts on goals and priorities related to the management of natural resources" 25 - have been implemented around the world.

While more knowledge is needed to develop the most effective mode of governance for communicating credible environmental information and improving consumer choice, a cross-jurisdictional comparative analysis may provide insight that can improve policy implementation, identify common trends, offer solutions to legal problems in other jurisdictions, and see if common answers can be found to common problems. Comparative law research is often carried out simply to better understand a particular area of law, in this case procurement law and its relationship to environmental interests, and is used in this thesis to assess the aims, goals, substance and efficacy of GPP. ${ }^{26}$ Comparative law research also identifies common themes across different legal systems, here the U.S and EU, with the intention of inquiring

\footnotetext{
${ }^{23}$ Gerhard Danneman, 'Comparative Law: Study of Similarities or Differences?' 418 in Mathias Reimann and Reinhard Zimmerman (eds), The Oxford Handbook of Comparative Law (Oxford 2006). See also ibid 419 (“...[I]t is often the right mixture of difference and similarity which makes comparative enquiries particularly attractive, regardless if the methodological approach pursued. Finding difference in similarity can be as fascinating as finding similarity in difference. If any general advice is to be offered, it is to keep an eye open for both similarity and difference, be it to trace those hidden pockets of difference in the basis of comparison, or to make the search for causal links a little less difficult, or to increase the chance of successful learning between legal systems.").

${ }^{24}$ Roux (n 18) 198.

25 International Union for Conservation of Nature, 'Governance and MEAs' $<$ https://www.iucn.org/theme/environmental-law/our-work/governance-and-meas > accessed 29 Jul 2019.

${ }^{26}$ Mario E Comba, 'Green and Social Considerations in Public Procurement Contracts: A Comparative Approach' in Roberto Caranta and Martin Trybus (eds), The Law of Green and Social Procurement in Europe (DJØF Publishing Copenhagen 2010) 299-300; Robert Cryer, Tamara Hervey, Bal Sokhi-Bulley and Alexandra Bohm, Research Methodologies in EU and International Law (Hart 2011) 28.
} 
as to whether legal regulation, here GPP, reflects a consistent manner of dealing with the issue across states or represents a local idiosyncrasy. ${ }^{27}$

As the methodological framework of comparative law is followed for the project, much preparation went into the project design. As recommended, the project describes and compares GPP in both jurisdictions, and it explains and evaluates the consequences of their similarities and differences. ${ }^{28}$

This research also engages the four critical parts of the comparative method: critical reasoning, evaluation of the law, discussion of how the law operates, and comparative observations that can shed light on all the legal cultures considered. ${ }^{29}$ This thesis, in researching green public procurement, has objectives that are descriptive and explanatory, as well evaluative. Thus, in such cases, one should consider legal systems that relate to the topic being considered and which may offer solutions and insights into how each function. ${ }^{30}$ The U.S. and EU fit these criteria given both their complementary governance structures and perceived role of the state in pursuing sustainability through GPP, allowing an assessment of both the efficacy of legal systems and governance models. ${ }^{31}$

The U.S./EU comparative approach works particularly well in the context of evaluating public procurement legal and policy choices given the divergent legal conclusions and policy concerns in the two geographies - in particular whether there is a conflict between commerce and environmentalism, and to what extent governments should be perceived as consumers when making purchasing decisions. This "conflict" between ecological and business goals or need for balance may only be viewed as such in the EU when limited to the procurement context ${ }^{32}$ (public procurement for social and environmental interests versus free trade). In comparison, the U.S. views procurement preferences as promoting free-market competition with municipalities and state agencies acting as consumers and developing competitive (perhaps underdeveloped) markets for goods for preferential characteristics. Even so, the political conflict between economic and environmental interests continues in the U.S.

The comparative roles of American states versus EU Member States in promoting environmental interests also raises sovereignty concerns and illustrates

\footnotetext{
${ }^{27}$ See Comba (n 26) 299-300.

${ }^{28}$ Marieke Oderkirk, 'The Need for a Methodological Framework for Comparative Legal Research' (2015) 70 Rabels Zeitschrift für ausländisches und internationales Privatrecht 589, 598.

${ }^{29}$ Eberle (n 17) 457.

${ }^{30}$ Oderkirk (n 28) 605.

${ }^{31}$ William Henry Clune, 'A Comparative Law Analysis of the Use of State-Level Green Public Procurement in the European Union and the United States' (2011) 1 Nordic Environmental LJ 3,3 .

${ }^{32}$ Nicholas de Sadeleer, EU Environmental Law and the Internal Market (Oxford 2014) liii.
} 
the inversion of what has been "nationalized" in the U.S. versus the European Union, where economic issues are left to the American states and defense left to the national government with the opposite occurring in Europe. Both systems secure economic and free market rights, and the states (either American states or EU Member States) operate semi-autonomously within their federations. ${ }^{33}$ Therefore, while state procurement activities are bound in both jurisdictions to comply and not contradict with primary law (U.S. and EU), it is precisely this tension between federal (i.e., U.S. or EU) economic goals and state procurement objectives that continually defines the legal doctrines in this area. ${ }^{34}$ Perhaps the EU public procurement reforms, in effect, render greater sovereignty back to the Member States to pursue environmental issues through economic means.

Unlike in the EU, public procurement law is not a major separate academic field in the U.S. (though the practice obviously arises in state and local government law through a call for tenders/bids and in federal government contracts $^{35}$ ), despite the ability of American states to act as free-market consumers and exert consumer-like preferences in making purchases. The availability of American states to use public procurement in this way, known as the "market participant exception" and discussed below, is a strong promoter of local industry in parts of the U.S., and also a potential means to acquire more environmentally friendly goods and services.

With the passage of the EU Public Sector Directive, the debate and discussion over how public procurement can be used to advance societal interests is now farther along in the EU than the U.S. While some perceive a conflict between business interests and environmental ones, GPP illustrates that this need not be the case. By comparing the U.S. and EU, one can see that public procurement preferences can promote environmental interests (or other societal interests) and not harm free competition. In fact, GPP as a tool can promote free competition and consumer choice (as used in the U.S.) as well as promote environmental innovation (as a goal in the EU).

In their efforts to promote environmental interests and social goals as well as help local economies, American states can pass legislation to encourage, and in some cases require, public institutions to purchase products produced in the state (i.e., a geographic preference) or by certain types of businesses (e.g., supporting minority and women owned businesses) due to the market participant exception. The use of a market participant exception to allow for geographic preferences would face stiff legal challenge under EU law. Despite

\footnotetext{
33 ibid 3.

34 ibid.

${ }^{35}$ Ralph C Nash, Jr, Karen R O’Brien-Debakey and Steve L Schooner, The Government Contracts Reference Book: A Comprehensive Guide to the Language of Procurement (4th edn, $\mathrm{CCH}$ 2013) 396-98.
} 
the existence of the exception under U.S. law and its lack of viability in Europe, American states and Member States can use public procurement to encourage or require the purchase of environmentally friendly goods, defined through any of a variety of measures, or pass legislation to apply to all products sold within the state. Thus, the U.S. provides an excellent comparative mirror for analyzing the role of public procurement and free trade within the EU.

This thesis also uses a global environmental legal approach to evaluate American and European procurement. "[E]nvironmental legal norms have become increasingly internationalized," and "growing international linkages are blurring the traditional divisions between private and public law and domestic and international law, promoting integration and harmonization" and have led to the creation of "global environmental law." of GPP and the global supply trades it impacts fit neatly within this paradigm. For example, while GPP may be domestically weaker than traditional regulation in terms of mandated results, it is stronger as a means to use domestic norms to influence international practice. U.S. environmental laws will only reach U.S.-located operations, but U.S. government procurement policies will apply to and shape the behavior of international companies. Thus, the comparative law method, in the global environmental context, proves a useful approach for this research. ${ }^{37}$

\subsection{Methodological Summary}

Through legal scientific, comparative, and deductive analysis, this project analyzes U.S. law in comparison to EU law and discusses the ability of public institutions to make environmental demands when purchasing products. To do so, this thesis employs the study of EU law, U.S. federal law, EU Member State national legislation, American state law, applicable directives in regulations, case law, legal literature, and guidance materials from public authorities. From a legal interpretation standpoint, this thesis recognizes that the U.S. and the EU and its Member States have different legal systems (common law versus primarily, with exceptions, civil law), traditions and sources of law, and also addresses the differences in their governance structures (U.S. federal

\footnotetext{
${ }^{36}$ Yang (n 19) 616.

${ }^{37}$ See Jan Darpö and Annika Nilsson, 'On the Comparison of Environmental Law' (2010) 3 J of Court Innovation 315, 315-36.
} 
government/American states versus European Union/Member States), the interpretation and deference to administrative law, ${ }^{38}$ and structures of the court system and litigation procedures.

The two comparative law traits of the U.S. and EU that are most intriguing in the GPP context, as discussed in Part 4, are notions of federalism in the U.S. versus European centralization and the role of the judiciary. The dominance of American federalism is defined by state sovereignty and local control, as well as a unique and historical skepticism of the role of a centralized national government. In the GPP context, this allows for creativity and flexibility to pursue new initiatives, but is dependent politically on communities, city councils, and state governments that place a high value on environmental protection. However, decentralization means that the aggregate actions still cannot meet the purchasing power of the federal government.

In terms of judicial differences, American courts are often perceived as being more activist, but in the GPP context they have simply deferred to American states under the market participant exception. Meanwhile, the Court of Justice of the European Union (CJEU), surprisingly laid much of the groundwork for the GPP principles found in the Public Sector Directive, as discussed below.

\footnotetext{
${ }^{38}$ Annika K Nilsson, Enforcing Environmental Responsibilities: A Comparative Study of Environmental Administrative Law (Uppsala 2011).
} 


\section{What is Green Public Procurement?}

\subsection{Introduction}

There exist many regulatory approaches to abating pollution in the natural environment and encouraging more environmentally friendly behaviors among producers and consumers. Green public procurement (GPP) is one such tool in a growing set of neoliberal regulatory mechanisms that do not require, but encourage, environmental norm change in public and private actors. Implementing GPP requires public institutions to take into account environmental externalities at stages of a product's life cycle, making it necessary for business to account for environmental harms in a quasi-private environmental governance regime. This Part 3 defines GPP, following a discussion of how GPP fits into the broader matrix of environmental regulation.

\subsection{Environmental Regulatory Approaches}

One could imagine a world with no regulation and where products contained no information; a world of anarchy that no one would want as it would be impossible to know the safety or composition of any purchased product. Many would also be equally troubled by a governance regime with full and complete regulation, where government mandated all production standards - a world lacking innovation and variety.

Instead, what generally exists is a public environmental governance regime that relies on a diverse set of regulatory tools to minimize environmental externalities. The regime works in conjunction with private environmental governance mechanisms where actions taken by non-governmental entities are designed to achieve traditionally governmental ends. Public environmental governance has now embraced a neoliberal model that moves away from traditional public regulation to encouraging private environmental governance and consumer choice mechanisms.

Neoliberalism denotes "forms of political-economic governance premised on the extension of market relationships. ${ }^{{ }^{39}}$ In the U.S., the historical rise of neoliberal environmental regulation perhaps began during the presidency of Jimmy Carter, but gained major traction during the Ronald Reagan and Bill

${ }^{39}$ Larner (n 10) 5. 
Clinton presidencies, laying the foundation for the type of free-market governance seen today. ${ }^{40}$ These neoliberal trends continued within Europe with the privatization of public services, and seeking environmental and social welfare gains through public procurement certainly fits this model.

Viewing public procurement from the prism of an economic exercise, its regulation displays strong neo-liberal influences. Such influences embrace the merit of efficiency in the relevant market and the presence of competition, mainly price competition, which would create optimal conditions for welfare gains. The connection between public procurement regulation and the neo-liberal approach to the European economic integration is reflected upon award criteria based on price. This feature of the legal framework focuses on price competition being inserted into the relevant markets and, assisted by the transparency requirement to advertise public contracts above certain thresholds, would result in production and distribution efficiencies, and drive the market towards an optimal allocation of resources. Removing protectionism and preferential treatment and inserting an environment of competition in public markets will bring about allocative efficiencies, which in turn will result in social welfare gains at European and national levels. ${ }^{41}$

While neoliberalism may avoid any one specific definition, it has been expressed over the last thirty years through various forms of local, national, and international experiments in laissez-faire political economy around the world, using regulations that aim to deploy markets as the solution to environmental problems. ${ }^{42}$ There are multiple regulatory tools available for addressing environmental and public health harms, or, for that matter, any resource or commodity. Perhaps the greatest challenge in pursuing environmental goals is recognizing that the proper law, regulatory tool, or public policy initiative, must be matched to the appropriate behavior to effectively facilitate change. ${ }^{43}$ As seen in Table 1, these regulatory methods may fall into six categories - information, standard-setting, bans, market-based, infrastructure, and public

\footnotetext{
${ }^{40}$ This is not to say that Congress did not employ market and informational approaches. See, e.g., the Environmental Impact Statement requirement in the National Environmental Policy Act, 42 USC $\S 1332$ (2012).

${ }^{41}$ Editorial, 'Public Procurement as Economic or Policy Exercise' (2017) 3 EPPPL.

${ }^{42}$ Robert Plastow, Neoliberalism in environmental governance: a paradoxical double movement? (University of Exeter, May 2010) <http://www.academia.edu/2703516/Neoliberalism_in_environmental_governance_a_paradoxical_double_movement $>$.

${ }^{43}$ Jason J Czarnezki, Everyday Environmentalism: Law, Nature and Individual Behavior 2 (ELI 2013).
} 
awareness and pollution prevention ${ }^{44}$ - providing a useful taxonomy as policymakers assess the regulatory options available to them for abating any environmental harm. ${ }^{45}$

Table 1: Regulatory Methods for Reducing Environmental and Public Health Harms

\begin{tabular}{|l|l|l|}
\hline Type & Also Known As & Examples \\
\hline Information & Labeling; inventories & Toxic Release Inventory \\
\hline Standard-setting & $\begin{array}{l}\text { Technology-based standards; } \\
\text { health-effects standards; }\end{array}$ & $\begin{array}{l}\text { National Ambient Air Quality } \\
\text { Standards }\end{array}$ \\
\hline Bans & Prohibitions & Plastic bag bans \\
\hline Market-based & $\begin{array}{l}\text { Cost-benefit analysis, eco- } \\
\text { nomic incentives; subsidies; } \\
\text { taxes; valuation of ecosystem } \\
\text { services }\end{array}$ & $\begin{array}{l}\text { Cap-and-trade greenhouse gas } \\
\text { programs }\end{array}$ \\
\hline Infrastructure & Architecture & Mass transit; parks \\
\hline $\begin{array}{l}\text { Public awareness and } \\
\text { pollution prevention }\end{array}$ & $\begin{array}{l}\text { Marketing campaigns; volun- } \\
\text { tary programs }\end{array}$ & $\begin{array}{l}\text { Composting and recycling pro- } \\
\text { grams; public service advertise- } \\
\text { ments }\end{array}$ \\
\hline
\end{tabular}

The purpose in accounting for different regulatory options is that "[1]aw can select among these various techniques in selecting the end it wants to achieve. Which it selects depends on the return from each." 46 It is important "to speak comprehensively about these tools--about how they function together, about how they interact, and about how law might affect their influence." ${ }^{\prime 47}$ In addition, to determining the correct regulatory tool, lawmakers and policymakers must "determine the appropriate level of government or private action best suited to address that category of behavior."

First, government regulations can set effects-based or technology-based standards, demanding that harms do not surpass a specific threshold or requiring the use of certain technologies to reduce harm. This, to a significant extent, is the "classical" type of regulation that has been the traditional focus of environmental law.

All environmental standards seek to reduce adverse effects in some manner. Effects-based environmental standards, often referred to as "health-

\footnotetext{
${ }^{44}$ Jason J Czarnezki, 'New York City Rules! Regulatory Models for Environmental and Public Health' (2015) 66 Hastings LJ 1621, 1626.

45 Jay P Kesan and Rajiv C Shah, 'Shaping Code' (2005) 18 Harvard J of L and Technology 319, 325; David M Driesen, Robert W Adler and Kristen H Engel, Environmental Law: A Conceptual and Pragmatic Approach (Aspen 2011); Czarnezki, Everyday Environmentalism (n 43); Lawrence Lessig, Code 2.0 (2d ed, CreateSpace 2009) (noting the regulatory constraints of the law, social norms, the market, and architecture).

${ }^{46}$ Lawrence Lessig, 'The New Chicago School' (1998) 27 J Legal Studies 661, 672.

47 ibid.

${ }^{48}$ Czarnezki, Everyday Environmentalism (n 43) 141.
} 
based" or "environment-based" standards, do so by expressly determining the level of environmental quality deemed acceptable as a goal. In establishing effects-based standards, it must be determined what level of environmental quality is adequate, or necessary, to protect health or environmental resources. The difficult part is deciding what is adequate..$^{49}$

For example, the U.S. Clean Air Act requires that the EPA promulgate National Ambient Air Quality Standards for criteria air pollutants which "in the judgment of the Administrator, based on such criteria and allowing an adequate margin of safety, are requisite to protect the public health." ${ }^{50}$ Regulation can also require agencies to set standards that available (or potentially available) technologies are capable of achieving and regulate compliance. ${ }^{51}$ For example, when Congress passed the Clean Water Act, "it changed the primary focus of federal law from the harm visited on the receiving water stream segments to end-of-pipe, technology-based permit limits." ${ }_{52}$

There is considerable debate over the efficiency of prescriptive regulations. ${ }^{53}$ On the one hand, they may be "inefficient and unwieldy," providing little incentive for innovation because, once the regulated party has satisfied the necessary requirements, the law creates no incentive to reduce harmful activities further. ${ }^{54}$ On the other hand, environmental regulation may encourage production process and design innovations. ${ }^{55}$

Second, government may regulate through information generation and labeling. Such information-based approaches can inform society about environmental and public health harms. Generation of information about the environmental consequences of actions can provide a means of encouraging better environmental performance for government institutions, private entities and individuals. ${ }^{56}$ The theory behind informational approaches is that the government can change people's behavior by encouraging them to think about the harm they are causing and by publicizing that harm. ${ }^{57}$ Information informs

\footnotetext{
49 ibid 135.

5042 USC $\S 7409(\mathrm{~b})(1)$.

${ }^{51}$ Driesen (n 45) 195.

52 David Drelich, 'Restoring the Cornerstone of the Clean Water Act' (2009) 34 Columbia J Environmental L 267, 304.

${ }^{53}$ Salzman (n 2) 365.

54 ibid.

55 ibid 365-66.

${ }^{56}$ Driesen (n 45) 329.

${ }^{57}$ Salzman (n 2) 373.
} 
government decision-making about how and whether to protect the environment, and can motivate private cleanup and the avoidance of environmental problems..$^{58}$

Examples of informational regulation include the Energy Star energy-efficiency labeling program, the Toxic Release Inventory, and the U.S. Department of Agriculture (USDA) organic food labeling program. Informational regulation can be useful when political will does not permit direct regulation. Studies indicate that information can trigger new environmental norms. For example, increased awareness of consequences of individual transportation behavior has a positive effect on willingness to reduce personal car use. ${ }^{59}$ However, it can be costly to produce accurate and verifiable information, and informational regulation does not require changes in consumer or corporate behavior. That said, there is potential value to government regulators of information learned through implementation of GPP schemes. What one learns about when, how and why products and companies impact the environment can help regulators understand where additional policy interventions would be useful.

Third, regulation can simply impose bans on certain harms that are unacceptable at any level. In recent years, communities have instituted bans on plastic bags and smoking in public places. Internationally, for example, signatories of the Stockholm Convention on Persistent Organic Pollutants, to which the U.S. is not a party, agreed to outlaw "chemical substances that persist in the environment, bioaccumulate through the food web, and pose a risk of causing adverse effects to human health and the environment." ${ }^{60}$

Fourth, society can pursue market-based regulation that considers cost-benefit analyses, economic incentives (e.g., subsidies) or disincentives (e.g., taxes), and valuation of ecosystem services. Market-based approaches, such as pollution charges and trading of pollution permits/credits, attempt to harness market forces to achieve equal or greater amounts of pollution control than prescriptive regulation in a more cost-efficient manner. ${ }^{61}$ The European Union cap-and-trade permitting system, "a cornerstone of the EU's policy to

\footnotetext{
${ }^{58}$ Driesen (n 45) 329.

${ }^{59}$ Annika M Nordlund and Jorgen Garvill, 'Effects of Values, Problem Awareness, and Personal Norm on Willingness to Reduce Personal Car Use' (2003) 23 J Environmental Psychology 339,345 .

60 Commission, 'Persistent Organic Pollutants (POPs)' $<$ http://ec.europa.eu/environment/chemicals/international_conventions/index_en.htm> accessed 16 Apr 162018 (defining persistent organic pollutants); Stockholm Convention on Persistent Organic Pollutants [22 May 2001].

${ }^{61}$ Jerold S Kayden, 'Market-Based Regulatory Approaches: A Comparative Discussion of Environmental and Land Use Techniques in the United States' (1992) 19 Boston College Environmental Affairs L Rev 565, 565.
} 
combat climate change and its key tool for reducing greenhouse gas emissions cost-effectively," is one such example. ${ }^{62}$

Market-based approaches, while currently popular, may prove challenging to implement. To the extent privatization is required, environmental resources are not easily amenable to commodification, and there are normative concerns that rub against privatization of environmental amenities in the public domain. ${ }^{63}$ Financial penalties (e.g., charges or taxes), however, increase the cost of polluting activities, discouraging pollution and waste and forcing polluters to bear the costs of their activities. ${ }^{64}$ Challenges to any such financial penalty include determining the correct price, as well as political concerns. Like taxes, financial penalties are often unpopular. ${ }^{65}$ Rather than a stick, the financial payment can also be a carrot in the form of payment or subsidy. Thus, one solution to the unpalatability problem for behavior modifying regulation is to choose carrots versus sticks based on the level of public palatability of the regulation.

Fifth, governments at all levels, sometimes with the financial support of private entities, can spend money on infrastructure that improves environmental outcomes including public transportation, bike lanes, and public parks. ${ }^{66}$ Admittedly, such infrastructure is not "regulation" per se, but to ignore its importance, in terms of both expense and the ability to shift social norms, would be to leave a gap in any analysis for what approach might best alleviate the problems of an environmental harm.

Sixth, public awareness (e.g., marketing campaigns) and pollution prevention (e.g., recycling and composting programs) are regulatory tools that can often prove cheaper than end-of-the-pipe controls and lead to voluntary action. ${ }^{67}$

The challenge is in determining which of the available regulatory tools will best abate the environmental or public health harm.

And even if we can agree that emissions of a particular pollutant are too high, that grazing levels of the local commons must be reduced, or that a local endangered species requires greater protection, a fundamental choice still remains: We need to decide how best to achieve these goals. Put another way, even if we agree on our starting point and end point, we still need to determine which path should take us there. Reliance on regulatory mandates? Market in-

\footnotetext{
${ }^{62}$ Commission, 'EU Emissions Trading System (EU ETS)' <http://ec.europa.eu/clima/policies/ets/index_en.htm> accessed Apr 16, 2018.

${ }^{63}$ Salzman (n 2) 368.

64 ibid 370-72.

${ }^{65}$ ibid 371-72.

${ }^{66}$ See Sarah Schindler, 'Architectural Exclusion: Discrimination and Segregation through Physical Design of the Built Environment' (2015) 124 Yale LJ 1934.

${ }^{67}$ Driesen (n 45) 387.
} 
struments? Pilot projects or information generation? Implementing environmental policy is where the rubber meets the road, and it has provided some of the most innovative policy instruments in all of American law. ${ }^{68}$

GPP is, essentially, a publicly induced private environmental governance model that incorporates standard-setting through environmental and technical criteria, information disclosure through labeling and accompanying standards, and market-based mechanisms in terms of measuring and pricing the environmental externalities of production and consumption.

\subsection{Defining Green Public Procurement}

Public institutions participate directly in markets as consumers or clients. ${ }^{69}$ Green public procurement (GPP) by governments and public institutions is more akin to green consumerism, namely the production, promotion and preferential consumption of goods and services on the basis of their pro-environment claims such as eco-labelling schemes and eco-efficient production standards. ${ }^{70}$ This is different than the promotion of sustainable consumption where change in consumption behavior needs to be accompanied by changes in social and physical infrastructures. ${ }^{71}$

GPP then attempts to serve as an effective environmental regulatory tool in a mode of alternative environmental governance allowing public institutions to create both public and private markets for more environmentally friendly goods, creating a model for environmental progress that bridges the gap between traditional environmental law $^{72}$ and private environmental governance. $^{73}$

While traditional public environmental law is well known and understood, private environmental governance is "a new model of legal and extralegal influences on the environmentally significant behavior of corporations and households." ${ }^{\prime \prime}$ Vandenbergh defines private environmental governance as "actions taken by non-governmental entities that are designed to achieve traditionally governmental ends such as managing the exploitation of common

\footnotetext{
${ }^{68}$ Salzman (n 2) 363 (emphasis in original).

${ }^{69}$ Francesco Testa and others, 'Drawbacks and Opportunities of Green Public Procurement: An Effective Tool for Sustainable Production' (2016) 112 J Cleaner Production 1893, 1893.

70 ibid (citing Lewis Akenji, 'Consumer Scapegoatism and Limits to Green Consumerism' (2013) 63 J Cleaner Production 13).

71 ibid.

${ }^{72}$ See Lazarus (n 2); Salzman (n 2).

${ }^{73}$ See Vandenbergh, 'Private Environmental Governance' (n 3).

74 ibid 133.
} 
pool resources, increasing the provision of public goods, reducing environmental externalities, or more justly distributing environmental amenities." ${ }^{\prime} 5$ Importantly, he includes private standard-setting activities such as global private labeling certification systems for consumer products and "bilateral standard-setting in the definition of private environmental governance, such as when private supply chain contracts include provisions that are designed to reduce the environmental harms arising from the suppliers' operations." ${ }^{.6}$ The inadequacy of public environmental law has led to a rise of certification systems like the Marine Stewardship Council and Forest Stewardship Council, and other private labeling schemes (e.g., dolphin safe tuna). ${ }^{77}$

GPP is the public promotion of this type of "bilateral standard-setting," and now companies are moving towards true cost accounting of their supply chain and developing life-cycle costing methodologies, at least at some points in the supply chain. Public law can promote more eco-friendly supply chains and innovation in product development, though accurate labeling and life-cycle costing is highly dependent upon scientific data and information exchange.

As discussed in Part 5 below, Europe's public authorities are significant economic players in their role as consumers. Green procurement initiatives began in the early 1990s in Europe, following the inclusion of GPP in the 1992 Rio Earth Summit and Agenda 21, becoming a significant feature of the European policy landscape and a global initiative by the late $1990 \mathrm{~s} .{ }^{78}$ In the U.S., GPP is rooted in the action of progressive state and local governments, while little had been advanced at the national level until the Obama Administration made energy efficient procurement national policy through executive order. While the U.S. local model provides flexibility and efficiency in implementation, it simply cannot create the sort of whole scale movement towards sustainability sought in Europe.

Green public procurement is but one pillar of sustainable public procurement (SPP) - a broader concept including the three pillars of economic, social, and environmental responsibility. "By using [government] purchasing power to choose environmentally friendly goods, services and works, they can make an important contribution to sustainable consumption and production." ${ }^{.79}$ This project focus on environmental issues in the procurement context rather than social and economic sustainability issues (e.g., public health, economic ine-

\footnotetext{
75 ibid 146.

76 ibid 147.

77 ibid 161-62.

${ }^{78}$ Christopher McCrudden, Buying Social Justice: Equality, Government Procurement, and Legal Change (Oxford 2007) 389-91.

79 Commission, 'Green Public Procurement' <http://ec.europa.eu/environment/gpp/index_en.htm> accessed 16 Apr 2018.
} 
quality, worker safety, etc.) as the development of the methodology for assessing environmental externalities (both negative and positive) has preceded social measures.

As an operational definition, "[g]reen public procurement (GPP) means that authorities take the environment into account when procuring goods, services or works for all stages of a product including life cycle of the procured goods," providing industry with real incentives for developing greener products and technologies. ${ }^{80}$ GPP may help break down perceived barriers to the development and purchase of eco-friendly products, including perceptions of being too expensive, lacking knowledge in developing environmental criteria, and lacking of a management focus on GPP. ${ }^{81}$ GPP also can increase private demand and consumer awareness for environmentally preferable products and services. ${ }^{82}$ (However, concerns remain, especially in the EU, that GPP may be used to discriminate in the marketplace and inhibit free trade.) In addition, the data received in a procurement process could provide information to governments that would prove useful in deciding how to directly regulate environmental harms and the industries that create them.

GPP is an environmental regulatory tool, but more difficult to label and categorize. While GPP is not traditional environmental regulation in that it is a voluntary instrument (at least in the current context), it serves as both market-based and standard-setting quasi-environmental regulation, resulting in "parallel" environmental governance depending upon both public regulation and private options to influence procurement/supply chain management. ${ }^{83}$ GPP also serves as a bridge between traditional government sponsored environmental regulation and private environmental governance.

"[P]rivate environmental governance is the development and enforcement by private parties of requirements designed to achieve traditionally governmental ends. ${ }^{.84}$ In GPP, it is the government that asks for conditions that are implemented by private institutions. Public-private interactions generate many of the environmental requirements that affect both corporate and household behavior and, in turn, environmental quality. ${ }^{85} \mathrm{And}$, in the context of GPP, government contracting entities can provide the coercive authority nec-

\footnotetext{
${ }^{80}$ Ari Ekroos, 'EC Legislation on Public Procurement and Sustainable Development' in Bugge (n 1$) 425$.

81 ibid 426.

${ }^{82}$ Sarah E Light and Eric W Orts, 'Public and Private Procurement in Environmental Governance' in Ken Richards and Josephine Van Zeben (eds), Encyclopedia of Environmental Law [Policy Instruments in Environmental Law] (Edward Elgar 2017) 2.

${ }^{83}$ Light, 'Parallels in Public and Private Environmental Governance' (n 3) 46-50.

${ }^{84}$ Vandenbergh, 'Private Environmental Governance' (n 3) 147.

85 ibid 133.
} 
essary to resolve environmental collective action problems (i.e., environmental externalities and incentives that private firms have to overexploit natural resources). ${ }^{86}$

Again, the challenge is in determining which of the available regulatory tools will best abate environmental harms and promote sustainable interests. While states in both the U.S. and Europe may better achieve environmental policies through more direct regulation of the goods and services in question, standing in the way of the success of such regulations are the high bars set by the dormant commerce clause and preemption doctrine in the U.S. and the internal market principles and harmonization doctrine in the EU (see Parts 6 and 7 below), as well as simple politics. As noted in previous scholarship, if EU Member States are to create innovative solutions to environmental problems, the evaluation of restrictions of trade would need to grant more weight to environmental standards as a legitimate government interest,${ }^{87}$ a discussion addressed in Part 7 below - this was accomplished to a great extent with the 2014 Public Sector Directive.

The 2014 EU Public Procurement Reform rules aim to facilitate better integration of environmental considerations in procurement procedures including allowing for environmental requirements, the use of criteria underlying environmental labels, and the option to take into account environmental factors in the production process and life-cycle analysis. ${ }^{88} \mathrm{EU}$ Member States now must determine how and to what extent they may set environmental goals through public procurement requirements. How will the GPP project be pursued by the EU Member States as they implement the public procurement EU Directive 2014/24/EU, ${ }^{89}$ in particular developing public procurement standards as they relate to eco-labeling and life-cycle analysis? Writes Dragos and Neamtu:

Traditionally, public procurement had only to be economically efficient, with little regard for other objectives than the purely economic ones. In recent times, however, due to a more general ascension of the sustainable development concept, governments have been put in the position to 'lead by example' and use their purchasing power in order to advance the goals of sustainable

\footnotetext{
${ }^{86}$ ibid 144, 147.

87 Jason J Czarnezki, 'States as Market Participants in the U.S. and the EU? Public Purchasing and the Environment' (2013) 2 Swedish Institute for Eur Policy Studies 1, $<$ http://www.sieps.se/en/publications/2013/states-as-market-participants-in-the-u.s.-and-theeu-public-purchasing-and-the-environment-20132/> .

88 Commission, 'Public Procurement Reform Factsheet No. 7: Green Public Procurement (2014) <https://ec.europa.eu/docsroom/documents/15509/attachments/1/translations/en/renditions/native $>$.

89 Commission, 'Public Procurement: Legal Rules and Implementation' <https://ec.europa.eu/growth/single-market/public-procurement/rules-implementation_en $>$ accessed $17 \mathrm{Apr}$ 2018.
} 
development; as a specific development, sustainable public procurement has been slowly creeping in. From 'secondary considerations' in the 2004 Directives, the need to include social and environmental considerations in public tendering procedures has led to the coining of new terms, much more powerful and all-encompassing, such as 'horizontal policies,' 'sustainable procurement' or even 'strategic procurement.' We can state that with the new 2014 Directives, the sustainability paradigm is almost taking over the realm of public procurement, and it is marketed as a major 'selling point' of the new legislation. ${ }^{90}$

This thesis considers the space, implementation, and value of environmental requirements in public procurement, and to what extent environmental law and GPP can trump legal norms and policies promoting internal market harmonization and free market completion in the U.S. and EU. These issues are of interest to many scholars, ${ }^{91}$ increasingly the courts,${ }^{92}$ state-run agencies and administrations, and private businesses. Can GPP and the tools it uses achieve the objective, described by the EU as, to "stimulate a critical mass of demand for more sustainable goods and services which otherwise would be difficult to get onto the market [and make GPP] a strong stimulus for eco-innovation?"93

GPP faces many challenges if it is to achieve such a goal. The implementation of these programs is often limited by existing policies and rules that seek to optimize economic growth and short-term best value. ${ }^{94}$ The driving forces behind the implementation of GPP are often established when it is part of broader political strategies and goals. ${ }^{95}$ Factors for success include: "supportive politicians (national and local), procurement officers and catering staff; a cultural context that supported changing provisioning routines and practices; and innovative criteria for awarding contracts that acknowledged the socio-environmental quality of the products and services offered." ${ }^{96} \mathrm{Im}$ plementation depends on political will and leadership and infrastructure that can balance the complex interplay between economic, environmental, and social drivers and demands. ${ }^{97}$

\footnotetext{
${ }^{90}$ Dacian C Dragos and Bogdana Neamtu, 'Sustainable Public Procurement in the EU: Experiences and Prospects' in Francois Lichère and others (eds), Modernising Public Procurement: The New Directive (DJØF Publishing 2014) 301-02.

${ }^{91}$ Caranta, (n 26) 15-51.

${ }^{92}$ Case C-573/12 Ålands Vindkraft AB v Energimyndigheten EU:C:2014:37.

93 Commission, 'Green Public Procurement' <http://ec.europa.eu/environment/gpp/index_en.htm> accessed 11 Apr 2018.

${ }^{94}$ Julie Smith and others, 'Balancing competing policy demands: the case of sustainable public sector food procurement' (2015) J of Cleaner Production 249, 250-51, 254 (concluding that there is "a need for clarity about what is meant by 'green' public sector food procurement and 'sustainable' public sector food procurement").

95 ibid 252.

96 ibid.

97 ibid 255.
} 
Thus, it may come as no surprise that the nations of the EU have surpassed the U.S. in pursuing GPP. The EU countries, for example, have long held positions seeking to mitigate the climate crisis and have formalized those goals in Kyoto Protocol, Paris Agreement, and United Nations Sustainable Development Goals. Meanwhile, the U.S. has announced its intent to withdraw from the Paris Agreement and only one-half of Americans do believe that global warming will pose a serious threat in their lifetime, despite overwhelming evidence to the contrary. The Trump Presidential Administration has also aggressively rolled back federal environmental regulations and protections. Thus, Americans may simply not value environmental health sufficiently to pursue it as a goal, especially when short-term economic growth and lower prices can be achieved by creating negative environmental externalities that will not be realized until the future. Implementing GPP is often limited by the "economic growth dogma" that aims to limit the most significant environmental problems, while primarily focusing on promoting a growing economy. ${ }^{98}$

Also challenging the uptake of GPP "are the lack of organizational resources for political support and of information on the real environmental impact of the products, the difficulties in finding suppliers or in preparing calls for tenders and purchasing, the lack of guidelines from higher-order authorities and of co-operation between authorities." ${ }^{99}$ There is a scarcity of data and indicators on the scope and scale of procurement schemes, the mechanisms employed, what works, the tangible benefits for sustainability and how these are extended and mobilized in the wider society. ${ }^{100}$

Other challenges to GPP include how to evaluate costs and benefits which may prioritize some values and actors over others (e.g., public health versus the environment versus worker safety). Once standards are created and demanded, larger economic entities may find themselves better able to comply compared to the small- and medium-sized enterprises (SMEs), ${ }^{101}$ which may hinder the very market innovation that GPP seeks to create.

\subsection{Summary}

In summary, many regulatory approaches exist that can abate pollution in the natural environment and encourage more environmentally friendly behaviors among producers and consumers. Perhaps the greatest challenge in pursuing

\footnotetext{
98 ibid. 250.

99 Testa (n 69) 1894.

${ }^{100}$ Smith (n 94) 255.

${ }^{101}$ Martin Trybus and Marta Andrecka, 'Favouring Small and Medium Sized Enterprises with Directive 2014/24' (2017) 3 EPPPL 224.
} 
environmental goals is recognizing that the proper law, regulatory tool, or public policy initiative must be matched to the appropriate behavior to effectively facilitate change. These regulatory methods may fall into at least six categories - information, standard-setting, bans, market-based, infrastructure, and public awareness and pollution prevention.

Green public procurement (GPP) is one such tool in a growing set of regulatory mechanisms that do not require, but encourage, environmental norm change in public and private actors. For an operational definition, GPP means that public authorities take the environment into account when procuring goods and services. The goal is to provide industry with real incentives for developing greener products and technologies, and help break down perceived barriers to the development and purchase of eco-friendly products, including perceptions of being too expensive, lacking knowledge in developing environmental criteria, and lacking of a management focus on GPP. GPP may also increase private demand and consumer awareness for environmentally preferable products and services.

While GPP is an environmental regulatory tool that can be defined, it is more difficult to label and categorize. While GPP is not a traditional environmental regulation in that it is a voluntary instrument (at least in the current context), it serves as both market-based and standard-setting quasi-environmental regulation, resulting in "parallel" environmental governance depending upon both public regulation and private options to influence procurement/supply chain management. GPP also serves as a bridge between traditional government sponsored environmental regulation and private environmental governance. Public environmental governance has now embraced a neoliberal model that moves away from traditional public regulation to encouraging private environmental governance and consumer choice mechanisms. Understanding the nature of the U.S. and EU legal systems is key to analyzing how such a hybrid regulatory tool such as GPP can be adopted and implemented. 


\section{Comparing the U.S. and EU Legal Systems}

\subsection{Introduction}

This Part 4 compares the structure of the U.S. and EU legal systems, especially those components that relate to public procurement law and process. From a legal interpretation standpoint, this thesis recognizes that the U.S. and the EU and its Member States have different legal systems (common law versus primarily, with exceptions, civil law), traditions and sources of law. This Part 4 also addresses the differences in their governance structures (U.S. federal government/American states versus European Union/Member States), the interpretation and deference to administrative law, ${ }^{102}$ and structures of the court system and litigation procedures. This transatlantic comparison is valuable because of their distinct legal structures and differences in public procurement implementation at the different levels of government (see Part 2 above).

This Part contains introductory material about the EU and U.S. to make this thesis useful for both American and European readers. Part 4.2 discusses the differences in governmental structure and legislation that are related to procurement law such as the creation of legislation, the "supremacy" of federal legislation in the U.S., and the precedence of EU law. Part 4.3 examines the legal basis of procurement law in the EU and grounds for procurement legislation in the U.S., while Part 4.4 discusses the tender process in the U.S. and EU. Further details on these topics specifically related to green public procurement can be found in Parts 6 (U.S.) and 7 (EU).

\subsection{Legal and Governmental Structures}

\subsubsection{Introduction to Basic Structures}

The differing basic legal and governmental structures of the U.S and EU, as described in this Part 4.2, have significance on the ability and flexibility of the states in each jurisdiction to engage in regulatory reform and policy implementation in the context of public procurement. ${ }^{102}$ See Nilsson, Enforcing Environmental Responsibilities: A Comparative Study of Environ-
mental Administrative Law (n 38). 
American federalism gives the states significant sovereignty and independence. Under the Tenth Amendment of the U.S. Constitution, all powers not granted to the federal government explicitly are reserved for the states or the people. Of relevance to procurement and environmental issues, states can establish local governments, regulate intrastate (i.e., within the state) commerce, and pass public health and safety legislation. In this way, American states may, ironically, be more independent than EU Member States in some contexts (at least in those areas where EU law, in contrast, is harmonized).

EU law is made effective through the Treaty on European Union (TEU), Treaty on the Functioning of the European Union (TFEU), national implementation of EU law by its Member States, and the enforcement power of the Court of Justice of the European Union (CJEU).

\subsubsection{Government Structure of the U.S.}

The United States has a federal political structure where the national and 50 state governments share power over the same geographic area, with the structure of the state governments nearly mirroring that of the federal government. The federal (i.e., national) government is granted enumerated and specific powers by the U.S. Constitution. The use of these powers has a binding effect on all states within the nation, similar to the way that EU treaties are binding on its Member States. All powers not granted to the federal government are reserved to the states or the people. Thus, any power not enumerated in the Constitution remains under state jurisdiction. However, the powers of federal government under the Commerce Clause (discussed in Part 6) and other provisions have been broadly construed. The Constitution's Supremacy Clause makes all state law, including state constitutions, subordinate to federal law.

The Constitution of the United States divides the federal government into three branches-executive, legislative, and judicial. The legislative branch (composed of the bicameral Congress made up of the Senate and House of Representatives) makes laws, the executive branch (President, Vice President, and administrative agencies) implements or "executes" the laws, and the judicial branch evaluates (through the court system) the constitutionality of the law's passed by Congress as well as the constitutional and statutory legality of any implementation by the executive branch.

Under Article 1 of the U.S. Constitution, Congress is granted powers to make laws, declare war, raise and provide public money and oversee its proper expenditure, impeach and try federal officers, approve presidential appointments, and approve treaties negotiated by the executive branch. Congress passes federal legislation, but it is important to know that administrative law, created in the executive branch by administrative agencies interpreting federal law, carries the force of law, and Executive Orders by the President are very influential in the interpretation and enforcement of federal law. 
Pursuant to Article II of the U.S. Constitution, the executive branch, led by the President, carries out and enforces laws, and is comprised of the Vice President, the Cabinet and federal agencies. Cabinet members serve as advisors to the President and include both the Vice President and the heads of major federal agencies. These agencies implement federal law according to the requirements stated in the statutory text, based on administrative law created by the agencies, and according to the directions of the President and agency heads.

The judicial branch is comprised of the Supreme Court and the lower federal courts. The Supreme Court of the United States is the country's highest court, having a binding effect on all lower federal courts and all state courts. The Supreme Court is comprised of nine justices nominated by the President, approved by the Senate, and appointed for life. Federal courts are courts of limited jurisdiction, meaning they can only hear cases authorized by the United States Constitution or federal statutes passed by Congress; usually, cases surrounding any federal legislation or significant legal issues between citizens of two different states.

State and local courts retain jurisdiction for matters outside of federal jurisdiction; though federal courts are free to and often interpret state law. The federal district courts (there is at least one in each state) are the starting point for most cases arising under federal jurisdiction. Any case decided in a district court can be appealed to a federal court of appeals. There are twelve such courts, which divide the country into their respective regions known as "circuits," in addition to the Court of Appeals for the Federal Circuit that has nationwide jurisdiction to hear appeals in specialized cases such as those involving patent laws, the Court of International Trade, and the Court of Federal Claims. Cases decided in the circuit courts can be appealed to the Supreme Court, but these cases must be accepted by the Supreme Court to be heard (a rare occurrence). The Supreme Court is, on average, asked to review more than 7,000 cases a year, but hears about 100 cases per year.

Public procurement can lead to disputes and litigation. Initial pre-award claims, or bid protests, can be made by tenderers that submit proposals or that planned to submit proposals. Bid protests can be filed with the agency issuing the tender notice, the Government Accountability Office (GAO), or the U.S. Court of Federal Claims. The vast majority of tenderers do so through the GAO. ${ }^{103}$

Claims are brought before the U.S. Court of Federal Claims pursuant to the Federal Courts Improvement Act of 1982 (FCIA). The Court of Federal Claims, first and foremost, resolves matters related to federal government contract, with more than one-third of the court's docket involving matters related

10331 USC $\S 3552$ (2015). 
to public contracts. ${ }^{104}$ Pursuant to the Contract Disputes Act of 1978 and FCIA, the U.S. Court of Appeals for the Federal Circuit possesses exclusive jurisdiction over appeals from the U.S. Court of Federal Claims. ${ }^{105}$ However, government contract appeals accounted for only $4 \%$ of the court's docket, suggesting that the Federal Circuit has "relatively few opportunities to issue precedential opinions that can meaningfully contribute to and shape the contours of government contracts law." 106

The American state governments are modeled after the federal government, each having its own written constitution and consisting of the same three branches. State and local governments play a more active role in the everyday lives of U.S. citizens, establishing police and fire departments, libraries, and public schools. In every state, the executive branch is headed by a governor who is directly elected by the people. In most states, the other leaders in the executive branch are also directly elected. The fifty states have legislatures made up of elected representatives who pass legislation, approve the state budget, and initiate tax legislation. State judicial branches are led by the state supreme courts that hear appeals from lower level state courts.

Local governments generally include two tiers: counties and municipalities. Counties are the largest political boundaries within a state; counties are comprised of municipalities, the smallest political structure in a state. Municipalities can be called townships, villages, boroughs, cities, or towns, and are generally distinguished by population density and total size. Municipalities take responsibility for parks and recreation services, police and fire departments, housing services, emergency medical services, municipal courts, public transportation, and public works (e.g., streets, sewers, snow removal, signage).

The structure of the state courts generally mirrors the federal judicial system. In the context of public procurement, two general dispute procedures exist at the state level, just as in the federal system: protests through the administrative agencies, and claims through state court systems. ${ }^{107}$

\footnotetext{
${ }^{104}$ Steven L Schooner, 'The Future: Scrutinizing the Empirical Case for the Court of Federal Claims' (2003) 71 George Washington L Rev 714, 718, 723.

${ }^{105}$ Ruth C Burg, 'The Role of the U.S. Court of Appeals for the Federal Circuit in Government Contract Disputes: A Historic View from the Bench' (2012) 42 Public Contract LJ 173.

106 Jimmie V Reyna and Nathaniel E Castellano, 'Successful Advocacy in Government Contracts Appeals Before the Federal Circuit: Context is Key’ (2016) 46 Public Contract LJ 209.

${ }^{107}$ For detailed information of what protests and litigation are permissible in American States, see The National Association of State Procurement Officials (NASPO), '2019 Survey of State Procurement Practices' <https://www.naspo.org/Portals/16/2018\%20Survey/2018\%20FINAL\%20Survey\%20Report_6-14-18.pdf?ver=2018-06-14-080105-470> accessed 29 Jul 2019.
} 


\subsubsection{Government Structure of the EU}

The political structure of the European Union (EU) is unique unto itself with its two levels of power: European and national. ${ }^{108}$ The EU is comprised of 28 Member States (though the United Kingdom is, as of this writing, continuing to pursue its departure) and was originally established to encourage economic cooperation, ${ }^{109}$ with the added view that this would limit the risk of future armed conflict on the European continent. ${ }^{110}$

The Treaty on the Functioning of the European Union (TFEU) and the Treaty on European Union (TEU) constitute the treaties on which the European Union is founded. ${ }^{111}$ Treaties comprise the primary form of legislation in the EU and undergird the founding of the Union. The EU only has the power to create legislation outlined in its treaties in the form of regulations, directives, and decisions. ${ }^{12}$ This includes measures with the aim of establishing or ensuring the functioning of the internal market. This market comprises an area without internal frontiers in which the free movement of goods, persons, services, and capital is ensured in accordance with the provisions of the Treaties (Article 26 TFEU). EU public procurement law is adopted with the aim of ensuring the functioning of the internal market, and incorporating the important legal principle of non-discrimination stemming from the TFEU which requires transparency and equal treatment. ${ }^{113}$ Accordingly, TFEU rules pro-

108 Jean-Jacques Verdeaux, 'Public Procurement in the European Union and In the United States: A Comparative Study' (2003) 32 Public Contract LJ 713, 714 n.4.

${ }^{109}$ Sue Arrowsmith, 'Introduction to the EU' in Sue Arrowsmith (ed), EU Public Procurement Law: An Introduction (2010) 14.

${ }^{110}$ Paul Craig and Gráinne de Búrca, EU Law: Text, Cases and Materials (6th edn, Oxford 2015) 2 (noting that the creation of the European Economic Community was a response to World War II); Catherine Barnard \& Steve Peers, European Union Law (2nd edn, Oxford 2017) ("The basic idea was simple but fundamental: due to closer trade-ties States would become dependent on each other and thus the imperative to go to war would be reduced.").

${ }^{111}$ Consolidated Version of the Treaty on European Union (TEU) and the Treaty on the Functioning of the European Union [2010] OJ C83 (TFEU).

112 Verdeaux (n 108) 722.

${ }^{113}$ Commission, 'Public Procurement in the European Union, Guide to the Community Rules on Public Procurement of Services Other Than in the Water, Energy, Transport and Telecommunications Sectors, Directive 92/50/EEC 5' (1997) ("Nevertheless, the award of such contracts is, of course, subject to the Treaty rules concerning the freedom to provide services and to the general principles of Community law such as non-discrimination, equality of treatment, transparency and mutual recognition."). 
hibit discrimination on grounds of nationality, including in public procurement (for example, by reserving contracts for national suppliers). ${ }^{114} \mathrm{EU}$ procurement rules are "necessary and integral components" to the free movement of goods. ${ }^{115}$

After World War II, the aim of the EU was to create a "free market" or "single market" among the Member States, reducing economic friction by, for example, removing customs duties and import quotas, and allowing citizens of one nation to work in another. ${ }^{116}$ Public procurement was not expressly defined or discussed in the treaties that formed the EU. ${ }^{117}$ However, the removal of trade barriers and the free market established by the EU's founding treaties provide a legal basis and rationale for today's EU public procurement law. ${ }^{118}$ Public procurement policy aims to further eliminate existing barriers and prevent the erection of new barriers for trade in the EU on the basis of principles of procurement law listed in Article 18 of Directive 2014/24/EU. One should not be surprised that EU public procurement reform took place via directives (discussed below), mechanisms that are "particularly useful when the aim is to harmonise the laws within a certain area, or to introduce complex legislative change." 119

Three bodies of the EU government foster establishment of EU legislation. ${ }^{120}$ First, the Council (often called the "Council of Ministers" and distinguished from the European Council made up of Heads of State) has shared legislative authority in the $\mathrm{EU}$ and is comprised of one ministerial agent from each Member State who represent the interests of their respective Member States. While formally one body, the government ministers from each EU country meet in different configurations according to the policy area to be discussed. ${ }^{121}$ With few exceptions, the Council must approve any legislation before it becomes EU law, including regulations and directives. ${ }^{122}$

Second, the European Parliament (EP), comprised of members directly elected by citizens of the Member States, acts as a co-legislator, sharing with the Council the power to adopt and amend legislative proposals and to decide

\footnotetext{
${ }^{114}$ Sue Arrowsmith, 'Introduction to the EU' (n 109) 38.

115 Jörgen Hettne, 'Public Procurment and European Standards: Fair Competition or Limits to Discretion' in Bogojević, Discretion in EU Public Procurement Law (n 9) 143; 'Completing the Internal Market: White Paper from the Commission to the European Council' COM(85) 310 .

116 ibid 16.

${ }^{117}$ Verdeaux (n 108) 720.

118 Arrowsmith, 'Introduction to the EU' (n 109) 15.

${ }^{119}$ Craig (n 110) 108.

${ }^{120}$ See generally Barnard (n 110) 38-69.

${ }^{121}$ David Langlet and Said Mahmoudi, Environmental Law and Policy (Oxford 2016) 8.

${ }^{122}$ Arrowsmith, 'Introduction to the EU' (n 109) 16.
} 
on the EU budget. Having evolved from its initial advisory role and especially in light of the Treaty of Lisbon, today the EP is "regarded as an equal partner with the Council in the legislative process." 123

Third, the European Commission is comprised of Commissioners from each Member State, each responsible for a different area of EU policy. In contrast to the Council, Commissioners are not representative of their Member State affiliates but act "independently and objectively for the EU itself." 124 The Commission has three main responsibilities: First, the Commission is responsible for initiating new EU legislation. While the Council and Parliament can deny approval or include changes to proposed procurement directives, the Commission creates and proposes the directives on behalf of the EU under Article 17(2) TEU. "The Commission is, therefore, at least formally, the 'engine' of the legislative process." 125 Second, under the power vested by Article 258 TFEU, the Commission enforces the rules of the EU by investigating whether Member States or subordinate bodies have violated EU law (though the Commission will solely sue the Member State, not a specific contracting authority, and normally for wrong application/transposition of the law, not for an error or mistake in a specific tender). Third, the Commission acts as an executive body on particular areas of EU law. For instance, it approves and enforces the limited exceptions to EU "single market" competition theory when Member States offer incentives and favorable loans (i.e., State aid) to in-country companies (e.g., utilities procurement). ${ }^{126}$

Under Articles 258 and 259 TFEU, the Commission has the power to investigate whether Member States have violated EU law, and where Member States do not comply with EU law, the Commission and other Member States may bring them before the Court of Justice of the European Union (CJEU). The CJEU interprets EU law in an effort to keep implementation and enforcement uniform across the Member States. While the CJEU's interpretation of EU law is binding over national courts as precedent, ${ }^{127}$ it does not serve as an appeals court for national cases. However, a national court may call on the CJEU to answer a question of EU law through a preliminary ruling.

Member States must abide by the decisions of the CJEU under the principle of sincere cooperation under Article 4(3) TEU, similar to how U.S. state courts and governments must abide by federal law and the rulings of the federal courts. In addition, Member States are bound by EU law and are prevented

\footnotetext{
${ }^{123}$ Langlet (n 121) 11.

${ }^{124}$ Arrowsmith, 'Introduction to the EU' (n 109) 18.

${ }^{125}$ Langlet (n 121) 9.

${ }^{126}$ Arrowsmith, 'Introduction to the EU' (n 109) 18.

${ }^{127}$ Langlet (n 121) 18.
} 
from adopting national legislation contrary to EU law, ${ }^{128}$ similar to the Supremacy Clause of the U.S. Constitution.

Member States are held responsible not only for their own violations, but violations committed by any subordinate public bodies (e.g., regional and local entities or public universities). ${ }^{129}$ Violations by Member States are brought before the CJEU. In the area of public procurement, reasons for violations to be brought before the CJEU are for failure to implement a directive, incorrectly implementing a directive, not following the appropriate procedures mandated for the procurement process, and direct awards without a tender. ${ }^{130}$

Secondary legislation consists of directives and regulations meant to further treaty objectives. Primary and secondary legislation is binding on all Member States (though binding in different ways, particularly when it comes to directives which formally bind solely to the effect; but see the discussion of "direct effect" below), and national laws conform with and implement EU legislation. ${ }^{131}$ While the EU maintains great latitude in deciding which type of legislation to pursue, procurement policy has customarily been formed through directives. Directives have been the primary form of legislation for procurement so as to leave Member States the freedom to accommodate their particular social, political, or administrative arrangements. ${ }^{132}$ Directives "define the legal framework within which each Member State must enact its own national statute in a limited period of time." ${ }^{133}$

As seen in national procurement legislation, some Member States simply refer to the Directive and that is their national law (e.g., in past years Denmark did so), other Member States 'copy and paste' the directives, and some create new national legislation, while others use the directives as a blueprint and add provisions representing national specifics. In other words, directives outline particular standards that a Member State must meet, but, at least formally, leaves the "form and method of implementation" up to the Member States. ${ }^{134}$

The Court of Justice for the European Union has stated that in order for a Member State to satisfy the requirements of a directive, it must do so in a manner that "provides for legally enforceable rights within the domestic system." ${ }^{135}$ Deadlines for passage of national implementing legislation are set out in each directive. Unlike a directive which requires action by the Member

\footnotetext{
${ }^{128}$ Case 6/64, Flaminio Costa v ENEL [1964] ECR 585, 593; Langlet (n 121) 18.

${ }^{129}$ Arrowsmith, 'Introduction to the EU' (n 109) 20.

${ }^{130}$ See ibid 19.

131 ibid 25.

132 ibid 28.

133 ibid 721.

134 ibid.

135 ibid 28.
} 
States for them be transposed into national law, under Article 288 of the Treaty of Lisbon, an EU regulation is "binding in its entirety and directly applicable in all Member States." 136

However, directives can have "direct effect," a concept first developed in the Van Gend en Loos case in 1963, ${ }^{137}$ in order to protect the rights of individuals. ${ }^{138}$ In Van Duyn and later Ratti, the CJEU held that directives may have "vertical direct effect," meaning that directives can be enforced directly by individuals against the state when its provisions are unconditional, sufficiently clear and precise, and after the time limit for their implementation has expired. ${ }^{139}$ This can result in the invalidation of conflicting domestic law of a Member State. ${ }^{140}$

The result of Van Duyn, Ratti and subsequent case law is that while Article 288 does not declare directives to be directly applicable, so that they do not automatically become part of national law upon adoption, if certain conditions are met, they may produce effects to some extent similar to those of regulations after the time limit for their implementation has expired and the state has not properly implemented them. ${ }^{141}$ This is so for those provisions in a directive which (a) are unconditional and sufficiently clear (meaning not needing an implementation to flesh out their normative content) and (b) can be considered to grant rights to EU citizens and companies. However, while directives have vertical direct effect against the State and State institutions, the CJEU has ruled that unimplemented directives cannot themselves impose obligations on individuals (i.e., there is no "horizontal direct effect"). ${ }^{142}$ Direct effects are limited to specific provisions rather than to the full directive (and it is the same with the EU treaties). In Delena Wells, the High Court held that the directive on the assessment of the effects of certain public and private projects on the environment (Directive 85/337) has direct effect, and an individual may rely on the directive and invoke its provisions to require an environmental assessment. ${ }^{143}$

In some contexts, individual rights and standing may be readily available (for example, protesting tenderers in procurement law cases, or advocating for property rights). In the procurement law context, there is nearly always an

${ }^{136}$ See Craig (n 110) 106-107; Langlet (n 121) 15.

${ }^{137}$ Case 26/62 Van Gen den Loos v Nederlandse Administratie Der Belastingen [1963] ECR 1.

${ }^{138}$ Craig (n 110) 201.

${ }^{139}$ Case 41/74 Van Duyn v Home Office [1974] ECR 1337; Case 148/78 Pubblico Minsistero v Tullio Ratti [1979] ECR 1629; Barnard (n 110) 149-150; Craig (n 110) 184, 200-04.

${ }^{140}$ Craig (n 110) 184.

141 ibid 203 (internal citations omitted).

142 ibid 184.

143 Case C-201/02 [2004], The Queen on the application of Delena Wells v Secretary of State for Transport, Local Government and the Regions, para 61. 
interested private party to appeal the decision (e.g., economic operators that have bid on tender notice). However, the notion of direct effect in the context of environmental law becomes of utmost importance as those who are concerned by EU law can challenge administrative decisions under the environmental law directives. ${ }^{144}$ In this latter context, the right is procedural in nature; ensuring access to justice in environmental law. ${ }^{145}$ This creates the possibility to challenge administrative application of EU directives containing obligations that are sufficiently precise and unconditional.

In the environmental law context, an environmental non-governmental organization (ENGO) is entitled to rely on any provision of EU environmental law which has direct effect and on national law implementing EU law. ${ }^{146}$ Thus, direct effect means that, first and as noted above, EU law has precedent over national law and courts must disapply national legal provisions that contradicts EU law, and, second, in the field of environmental law, the consequence of direct effect is that it creates an obligation of national procedural law that ENGOs be able to challenge decisions regardless of national law on the matter. This leaves open the question of whether an ENGO could challenge a public procurement decision if such a purchasing decision has a significant and adverse impact on the natural environment.

When there is a breach of EU law, the CJEU established in Francovich the principle of state liability to pay compensation, and required national courts to provide a damage remedy for breach of an EU provision that lacked direct effect. ${ }^{147}$ Parties seeking to vindicate a right to trade (usually corporate interests) are likely to fit within the notion of a directly effective right or a right protected by Francovich. ${ }^{148}$ The current test for state liability are stated in Brasserie du Pêcheur/Factorame:

\footnotetext{
${ }^{144}$ Jan Darpö, 'Article 9.2 of the Aarhus Convention and EU Law: Some Remarks on CJEUs Case-Law on Access to Justice in Environmental Decision-Making' (2014) 11 J for Eur Environmental and Planning L 367, 376.

145 Jan Darpö, 'Understanding the Nuts and Bolts - Scientific and Technical Knowledge in Environmental Litigation: National solutions, EU requirements and current challenges' in Lorenzo Squintani, Jan Darpö, Luc Lavrysen and Peter-Tobias Stoll (eds), Managing Facts and Feelings in Environmental Governance (Edward Elgar 2019) 88-89. See also Jan Darpö, 'Pulling the trigger: ENGO standing rights and the enforcement of environmental obligations in EU law' in Sanja Bogojević and Rosemary Rayfuse (eds), Environmental Rights in Europe and Beyond (Hart 2018) 253-281.

${ }^{146}$ Commission, Commission Notice on Access to Justice in Environmental Matters (28 Apr 2017) 34 .

${ }^{147}$ Joined Cases C-6/90 and C-9/90 Francovich and Bonifaci [1991] ECR I-5357.

${ }^{148}$ Stephen Weatherill, 'EU Law on Public Procurement: Internal Market Law Made Better' in Bogojević, Discretion in EU Public Procurement Law (n 9) 39. See also ibid 43-44 (discussing Directive 89/665 and Directive 2007/66).
} 
Community law confers a right to reparation where three conditions are met: the rule of law infringed must be intended to confer rights on individuals; the breach must be sufficiently serious; and there must be a direct causal link between the breach of the obligation resting on the State and the damage sustained by the parties. ${ }^{149}$

State liability exists not only for non-implemented directives, but now also for any (manifest and serious) breach of EU law, including wrongly implemented and/or applied directives, including in the public procurement context, ${ }^{150}$ though within some limitations. ${ }^{151}$

Finally, the principle of indirect effect requires national courts, as Member State entities responsible for the fulfillment of EU obligations, to interpret domestic law consistently with a directive that was not implemented or not properly implemented in the Member State as long as the domestic rules on interpretation allow such a result. In Marleasing, the court stated:

[T] he Member States obligation arising from a directive to achieve the result envisaged by the directive and their duty under [Article 4(3) TEU] to take all appropriate measures, whether general or particular, to ensure the fulfilment of that obligation, is binding on all the authorities of Member States including, for matters within their jurisdiction, the courts. It follows that, in applying national law, whether the provisions in question were adopted before or after the directive, the national court called upon to interpret it is required to do so, as far as possible, in the light of the wording and the purpose of the directive in order to achieve the result pursued by the latter and thereby comply with the third paragraph of [Article $288 \mathrm{TFEU}] .{ }^{152}$

Thus, even national law adopted before EU legislation at issue must be interpreted to conform with EU law.

\footnotetext{
149 Joined Cases C-46/93 and C-48/93 Brasserie du Pêcheur/Factorame [1996] ECR I-5357, para 35.

${ }^{150}$ See generally Duncan Fairgrieve and François Lichère, Public Procurement Law: Damages as an Effective Remedy (Hart 2011).

${ }^{151}$ Fosen-Linjen AS, supported by Næringslivets Hovedorganisasjon (NHO) v AtB AS (E-7/18, Fosen-Linjen II), para 121 ("Article 2(1)(c) of the Remedies Directive does not require that any breach of the rules governing public procurement in itself is sufficient to award damages for the loss of profit to persons harmed by an infringement of EEA public procurement rules.").

${ }^{152}$ Case C-106/89 Marleasing SA v La Commercial Internacionale de Alimentacion SA [1990] ECR I-4135.
} 


\subsection{The Legal Basis for Public Procurement Law}

Directives fall into two paradigms in the context of "harmonisation." 153 First, directives may create minimum standards where Member States are allowed to create stricter standards (minimum harmonization); something common in the context of environmental law (for example, the Directive protecting wild birds, 2009/147/EC). ${ }^{154}$ Although, if Member States exceed these minimum standards, all treaty provisions remain applicable. Second, a directive may create a "harmonised" standard that is common across the EU's internal market and does not allow for any divergence (total harmonization). ${ }^{155}$ For example, to create a level playing field for businesses across all Member States, EU law sets out harmonized public procurement rules that state how public authorities purchase goods, works and services (see also below further discussion of "legal basis" and Article 114 TFEU). Finally, it must be noted that "it is not necessarily easy in practice to decide whether a particular EU act seeks to bring about total harmonization or leave Member States free to adopt stricter rules or rely on grounds not listed in the measure."156

"The EU Treaties use the term 'competence' as a synonym for both 'legal authority' or "power."'157 The EU only has "conferred competencies," limited decision-making power transferred to it by the Member States; ${ }^{158}$ akin to the enumerated powers of the U.S. federal government. The legal basis and legislative competence for procurement law in the EU is its goal of establishing a functional internal market under Article 26 TFEU, defined "as an area of free movement for persons, capital, goods and services and all of these factors of production have revealed themselves to touch on matters of extreme national sensitivity." ${ }^{59}$ Pursuant to the principal of conferral under Articles 1 and 4(1) TEU, every binding act that the EU adopts must have a legal foundation either in the Treaties or in a valid pre-existing normative act, a foundation known as the "legal basis" of the act. ${ }^{160}$ The legal basis for EU public procurement also relies upon the proper adoption of legislation under Article 114 TFEU. ${ }^{161}$ This

\footnotetext{
${ }^{153}$ Barnard (n 110) 322.

154 ibid.

155 ibid.

156 ibid 323.

157 ibid 105.

${ }^{158}$ Langlet (n 121) 7.

${ }^{159}$ Gareth Davies, 'The competence to create an internal market: conceptual poverty and unbalanced interests' in Sacha Garben and Inge Govaere, The Division of Competences between the EU and the Member States (Hart 2017).

${ }^{160}$ Barnard (n 110) 106.

${ }^{161}$ See ibid. See also Barnard (n 110) 106.
} 
discussion continues below, and in Part 7 with a description of the legislative and judicial foundations of EU procurement law.

There are now, pursuant to the Lisbon Treaty, three categories of competencies whereby the EU has legal authority to act. The EU may have (1) exclusive competence, (2) shared competence, or (3) competence only to take supporting, coordinating or supplementary action. ${ }^{162}$ Exclusive competence means power that the EU is legally obliged to exercise and where only EU, not Member States, may legislate and adopt legally binding acts ${ }^{163}$; akin to field preemption in U.S. law. The bulk of EU competencies are "shared," a residual category for any competence that is not "exclusive" or "ancillary"; these principle areas include the internal market, agriculture and fisheries, the environment, consumer protection, transportation, energy, justice and safety, and public health. ${ }^{164}$ The final category of competence allows the EU to take action to support, coordinate and supplement Member State action without harmonizing Member State laws. ${ }^{165}$ Public procurement, as necessary to the functioning of the EU internal market, is a shared competency under Articles 4 and 5 TEU and Article 4 TFEU.

In the U.S., Congress passes legislation and administrative agencies create implementing regulations that dictate the lawful actions of the federal government and may require action by the states. In the context of procurement, U.S. federal law does not automatically apply to state and local governments. In terms of the legal basis for procurement law on the American side, the U.S. Congress can pass legislation regarding the purchasing power of the federal government pursuant to the "necessary and proper" clause of the U.S. Constitution (Art. I, Sec. 9, cl. 18). It is certainly "necessary" and "proper" for the federal government to buy goods and services in order to properly function. Congress, though it could choose to do so, has not yet exerted its vested power under the Commerce Clause (Art. I, Sec. 9, cl. 3) to dictate procurement rules for state and local purchasing programs. American states and their lower level counties and municipalities have great autonomy in the procurement context as discussed further in Part 6 below.

In contrast, EU directives are applicable to the Member States, and legislation by Member States apply to all local governments; though in the procurement context the individual autonomy of municipalities varies by country as some have strong national central purchasing authorities (see Article 37 of Directive 2014/24/EU) and other countries allow significant choice and deference to local governments.

\footnotetext{
${ }^{162}$ Craig (n 110) 73.

${ }^{163}$ Barnard (n 110) 107.

164 ibid 108.

${ }^{165}$ Craig (n 110) 86.
} 
Such discretion is allowed under Article 4 TEU as the EU and its Member States, as noted above, have shared competences in areas of the internal market, environment and social policy. ${ }^{166}$ Article 4(1) TEU makes clear that "competences not conferred upon the Union in the Treaties remain with the Member States," similar to the Tenth Amendment of the U.S Constitution. Article 7 TEU states that the EU institutions must consider treaty objectives when adopting measures falling within their competences. In regard to environmental considerations in public procurement, even stronger wording is found in Article 11 TFEU, known as the "environmental integration clause," stating:

Environmental protection requirements must be integrated into the definition and implementation of the Union policies and activities, in particular with a view to promoting sustainable development. ${ }^{167}$

Thus, Article 11 TFEU provides that environmental protection requirements be integrated into the definition and implementation of EU policies and activities, while Article 191 TFEU instructs the EU to have a high level of environmental protection and lists the main principles of EU environmental law such as the precautionary principle and polluter-pays-principle. ${ }^{168}$

However, there is significant ambiguity as to the precise scope and effects of the obligations arising from Article 11 TFEU, ${ }^{169}$ especially given its "steady strengthening". ${ }^{170}$ While it seems doubtful that EU must introduce environmental standards as an obligation to all public procurement, it is clearly legitimate to allow environmental (and social) considerations in public procurement at the EU level. ${ }^{171}$

This then raises the question of to what extent environmental considerations can be integrated in procurement law, or are obliged to be included (i.e., "must" be included) under Article 11 TFEU. ${ }^{172}$ Given the environmental integration principle above, recognition of harmonization of the internal market,

\footnotetext{
${ }^{166}$ See Craig (n 110) 83; Barnard (n 110) 109; Langlet (n 121) 46; de Sadeleer (n 32) 127-134.

${ }^{167}$ Marta Andhov, 'Contracting authorities and strategic goals of public procurement - a relationship defined by discretion?' in Sanja Bogojević, Xavier Groussot, Jörgen Hettne (eds) Discretion in EU Procurement Law (Hart 2019) 123 (citing Article 11 TFEU).

168 de Sadeleer (n 32) vi.

${ }^{169}$ Andhov, 'Contracting authorities and strategic goals of public procurement - a relationship defined by discretion?' (n 167) 123.

170 Julian Nowag, 'Article 11 TFEU and Environmental Rights' 155 in Sanja Bogojević and Rosemary Reyfuse, Environmental Rights in Europe and Beyond (Hart 2018).

171 ibid.

172 de Sadeleer (n 32) 25-26 (“Article 11 TFEU poses a concrete obligation. Indeed, a literal interpretation of Article 11 FEU suggests that there is an obligation to 'integrate' and not merely take into account... It follows that EU institutions cannot ignore environmental protection requirements when pursuing other policies.").
} 
and the allowance of shared competency in procurement and environmental law, could a Member State require sustainable/green public procurement (which may be necessary to achieve adequate GPP and LCC methodologies and implementation as discussed in Parts 9 and 10 below)? Must the EU make sustainable public procurement mandatory? Do environmental protection and sustainability principles allow for pro-environmental discretion in procurement policy even in the face of pro-market harmonization?

\subsection{The Tender Process}

\subsubsection{Procurement Roles in the U.S and EU}

American states and their local governments have significant autonomy in purchasing decisions, but the U.S. federal government also spends significant public funds. In contrast, the EU budget itself is far less than the public expenditures of the Member States. In addition, compared to the U.S., local governments in the EU engage in far more procurement vis-à-vis their national governments, owing to military spending in the U.S. and diffuse procurement responsibilities for local governments within the EU Member States. (For further discussion of the economics of public procurement, see Part 5 below). In an effort to understand how legislation translates to on-the-ground procurement practices by these government entities, this Part 4.4 briefly summarizes the public procurement tender processes in the United States and European Union. The implementation of green public procurement necessarily occurs through these technical processes.

\subsubsection{Tender Processes in the U.S.}

In the federal procurement process, all solicitations and awards must be posted on the "Government-wide Point of Entry" found on the website for Federal Business Opportunities (www.fbo.gov). ${ }^{173}$ At minimum, a solicitation informs potential contracting economic entities of what the government agency wants to purchase, provides instructions to the tender offerors, identifies the method that will be used to evaluate offers, and includes a deadline for the submission of bids or proposals. Interested companies prepare their offers in response to

\footnotetext{
${ }^{173}$ For an overview of the U.S. procurement system, see Christopher R Yukins, The U.S. Federal Procurement System; An Introduction (2017) <https://scholarship.law.gwu.edu/cgi/viewcontent.cgi? article $=2569 \&$ context $=$ faculty_publications $>$.
} 
the solicitation and agency personnel evaluate the offers. Solicitation and offers must be in accordance with provisions of the Federal Acquisition Regulation (FAR), discussed further in Part 6.6 below. ${ }^{174}$

There are three primary procurement methods used by the federal government: sole source acquisition, competitive acquisition, and sealed bidding; the method being used always outlined in the solicitation. ${ }^{175}$ Sole source acquisition is used for the purchase of supplies or services after soliciting and negotiating with only one business, and is typically used for technical and specific needs that can often only be met by that one source. ${ }^{176}$ Generally, sole source acquisitions are only permitted when competitive solicitation and sealed bids are impracticable. ${ }^{177}$

Competitive acquisition is intended to foster an impartial negotiation process between the government and potential contractors, and is now the dominant procurement method. In competitive acquisition the tender requirements are clearly definable, the risk of unsuccessful performance is minimal, and cost plays a dominant role in the award.

In sealed bidding, the public can bid, and contracts are awarded to the lowest responsible bidder. Consistent with best practices, invitations for sealed bids must describe the government requirements clearly, and the specifications must not be overly restrictive in a manner that might limit the number of bidders.

\subsubsection{Tender Process in the EU}

"Different in many ways from that of the United States, the European public procurement system is governed by the same basic principles: open competition, equity, and transparency." ${ }^{178}$ In the EU tender process, contracting authorities will publish an official tender notice, and often a prior information notice (PIN). PINs are released well in advance of an actual tender notice (generally at the beginning of the fiscal year), offering a projection of expected purchases in the coming fiscal year.

As part of the pre-procurement stage, the production of PINs is voluntary and are not binding on a contracting authority. However, PINs may increase

\footnotetext{
${ }^{174}$ L Elaine Halchin, 'Overview of the Federal Procurement Process and Resources' (Congressional Research Service 2012) <https://fas.org/sgp/crs/misc/RS22536.pdf>.

${ }^{175}$ Federal Deposit Insurance Corporation (FDIC), 'DIC OMWI Education Module: Understanding the Government Solicitation Bid Package' <https://www.fdic.gov/about/diversity/sbrp/52.doc > accessed 29 Jul 2019.

1762020 VET, 'Sole Source' $<$ https://cdn.ymaws.com/www.wipp.org/resource/resmgr/gm5_podcasts_rev/Sole_Source.pdf> accessed 15 Jul 2018.

${ }^{177}$ US. Department of Justice, 'Sole Source Justification' <https://ojp.gov/training/pdfs/SoleSource-FactSheet-C.pdf> accessed 16 Jul 2018.

178 ibid 726.
} 
the likelihood of a better offer by an economic entity, extending the time for tenderers to prepare. ${ }^{179}$ Furthermore, it allows for contracting authorities to substantially shorten timescales. ${ }^{180}$

Tender notices detail the technical specifications, estimated value, scope and nature of the tender as well as the terms and conditions for participation in the procurement process (e.g., award criteria, bidding procedure). Technical specifications define the characteristics required of the good or service requested. ${ }^{181}$ Award criteria are used to identify which of the eligible tenderers will deliver best value for money, considering the price, quality and means of production. (As discussed in Part 7 below, the 2014 Public Sector Directive has established that production processes and other stages of a product's life cycle may be included in the technical specifications or award criteria.) Notices are published in the supplement to the Official Journal of the European Union (OJEU), and are also available online via the Tenders Electronic Daily (TED). ${ }^{182}$

To encourage open competition and transparency, the OJEU publishes public notices of tender into every official language of the EU. ${ }^{183}$ In practice, contracting authorities submit notices via national or sector-specific e-procurement systems. Interested economic entities must then request the more comprehensive full tender documents from the contracting authority. ${ }^{184}$ While a cornerstone of transparency in EU procurement system is notice, the EU does not require pre-bid conferences, public bid openings, or post-award debriefings as is often the case in the U.S., ${ }^{185}$ though there is a duty to inform under Article 55 of the Public Sector Directive. Once notices have been published, the bidding process takes place.

The most common bidding procedure is the open procedure, whereby any and all candidates are able to assert an offer without the need to demonstrate suitability or capacity in advance. Candidates invited to tender are addressed on a pass/fail basis. The open procedure is the most common process, accounting for over two-thirds of contracts advertised in the OJEU. ${ }^{186}$ Other bidding

\footnotetext{
179 Abby Semple, A Practical Guide to Public Procurement (1st edn, Oxford 2015) 71-72 (A Practical Guide).

${ }^{180}$ Alastair Caithness, What is a Prior Information Notice (PIN)? (LinkedIn 10 Mar 2015) $<$ https://www.linkedin.com/pulse/what-prior-information-notice-pin-alastair-caithness/>.

181 ibid 106.

${ }^{182}$ Semple, A Practical Guide (n 179) 75.

183 ibid 57.

${ }^{184}$ Global Affairs Canada, 'European Union Government Procurement Guide for Canadian Businesses' (2017) <http://www.international.gc.ca/gac-amc/assets/pdfs/publications/European-Union-Government-Procurement-Guide-ENG.pdf $>$.

185 ibid.

${ }^{186}$ Semple, A Practical Guide (n 179) 73.
} 
procedures are multi-stage procedures based upon selection criteria, requiring full procurement documents to be available electronically at the time a notice is published. ${ }^{187}$

The second most common procedure, and the most commonly used of the multi-stage procedures, is the restricted procedure. ${ }^{188} \mathrm{Here}$, the contracting authority chooses who can be evaluated as a candidate for the contract based on the selection criteria prior to awarding a contract and then submits invitations for bids to a limited number of economic operators. The restricted procedure is most often employed for contracts that present an unknown number of candidates (e.g., a large number of candidates under the open procedure can waste time and money). The selection criteria for candidates is weighted and scored, and the selection criteria components and the minimum number of candidates must be stated in the contract notice. ${ }^{189}$

Multi-stage procurement procedures involve selection criteria used to assess the economic entity's ability to perform the proposed contract. Technical specifications dictate what goods or services will be provided or performed in the future under the contract. Selection criteria is based on three characteristics: suitability to pursue a professional activity, the economic and financial standing of the candidate, and technical and professional ability. ${ }^{190}$

Once parties have been invited to tender, evaluations of the final bids are made (sometimes after a round of dialogue or negotiations) and contracts awarded. The contract is awarded based on a tender's evaluation against the technical specifications and the award criteria outlined by the contracting authority.

\subsection{Summary}

In order to engage in a comparative analysis of GPP in the U.S. and EU, one must gain a basic understanding of the structures of their legal systems, the legal basis for procurement law in both jurisdictions, and how the tender process works. The differing basic legal and governmental structures of the U.S and EU have significance on the ability and flexibility of the states in each

\footnotetext{
187 ibid 74.

188 Other multi-stage procedures include the Competitive Procedure with Negotiation (where the contracting authority is required to develop a specification of its requirements in advance of inviting submissions from bidders and to structure the negotiation around these requirements), the Competitive Dialogue (where the development of specified requirements by the contracting authority involves dialogue directly with bidders), and the Innovation Partnership (generally used to develop new technology). See Semple, A Practical Guide (n 179) 74-84.

189 ibid 74.

190 ibid 99.
} 
jurisdiction to engage in regulatory reform and policy implementation in the context of public procurement.

American federalism gives the states significant sovereignty and independence. Under the Tenth Amendment of the U.S. Constitution, all powers not granted to the federal government explicitly are reserved for the states or the people. Of relevance to procurement and environmental issues, states can establish local governments, regulate intrastate (i.e., within the state) commerce, and pass public health and safety legislation. EU law is made effective through the Treaty on European Union (TEU), Treaty on the Functioning of the European Union (TFEU), national implementation of EU law by its Member States, and the enforcement power of the Court of Justice of the European Union.

The legal basis and legislative competence for procurement law in the EU is its goal of establishing a functional internal market under Article 26 TFEU, providing for the free movement for persons, capital, goods and services. Pursuant to the principal of conferral under Articles 1 and 4(1) TEU, every binding act that the EU adopts must have a legal foundation either in the Treaties or in a valid pre-existing normative act, a foundation known as the "legal basis" of the act. The legal basis for EU public procurement also relies upon the proper adoption of legislation under Article 114 TFEU.

In terms of the legal basis for procurement law on the American side, the U.S. Congress can pass legislation regarding the purchasing power of the federal government pursuant to the "necessary and proper" clause of the U.S. Constitution (Art. I, Sec. 9, cl. 18). It is certainly "necessary" and "proper" for the federal government to buy goods and services in order to properly function. Congress, though it could choose to do so, has not yet exerted its vested power under the Commerce Clause (Art. I, Sec. 9, cl. 3) to dictate procurement rules for state and local purchasing programs.

Pursuant to these powers, the tender process for public procurement is performed at local, state and national levels in the EU and U.S., with the effect of having significant economic impact as discussed in Part 5 below. 


\section{The Economic Power of Green Public Procurement}

\subsection{Introduction}

The global value of public procurement spending is enormous. Just the OECD countries alone spend a total of $€ 1000$ billion per year and in the EU over 250000 public authorities each year spend around 14-19\% of GDP on the purchase of services, works and supplies. ${ }^{191}$

As can be seen in the above quote, there is significant potential for green public procurement (GPP) to create markets for more environmentally friendly goods. GPP can, therefore, serve as an effective environmental regulatory tool and mode of alternative environmental governance allowing public institutions, creating a model for environmental progress bridging the gap between traditional environmental law and private environmental governance. But any such success depends upon, at baseline, public procurement comprising a significant part of the economy. This is the case in both the EU and U.S. This means that, as part of the procurement process, public calls for tenders would contain environmental criteria in the specific technical specifications for the product being purchased, award criteria (i.e., what characteristics will be considered in the awarding of the contract), and perhaps even in the introductory description in the call.

\subsection{The Economic Power of U.S. Public Procurement}

In the U.S., federal spending accounts for about $\$ 3.8$ trillion, over $20 \%$ of gross domestic product (GDP) (based on fiscal year 2015). ${ }^{192}$ Discretionary spending accounts for $\$ 1.11$ trillion of this total. The federal government

\footnotetext{
${ }^{191}$ Foreword, 3 EPPPL (2017).

192 Nat'l Priorities Project, 'Federal Spending: Where Does the Money Go' <https://www.nationalpriorities.org/budget-basics/federal-budget-101/spending/> accessed 17 Apr 2018.
} 
spends approximately $\$ 530$ billion annually on goods and services. ${ }^{193}$ As seen below, green public procurement could have vast economic potential in multiple sectors.

$\begin{array}{ll}\text { Total Federal Spending, budgeted for fiscal year } & \mathbf{2 0 1 5} \text { - Total } \mathbf{\$ 3 . 8} \text { Trillion } \\ \text { Science: } & \text { \$29.81 billion } \\ \text { Energy \& Environment: } & \$ 44.85 \text { billion } \\ \text { International Affairs: } & \$ 50.22 \text { billion } \\ \text { Housing \& Community: } & \$ 61.48 \text { billion } \\ \text { Transportation: } & \$ 84.99 \text { billion } \\ \text { Education: } & \$ 102.26 \text { billion } \\ \text { Food \& Agriculture: } & \$ 135.7 \text { billion } \\ \text { Veteran's Benefits: } & \$ 160.63 \text { billion } \\ \text { Interest on Debt: } & \$ 229.15 \text { billion } \\ \text { Military: } & \$ 609.3 \text { billion } \\ \text { Medicare \& Health: } & \$ 1.05 \text { trillion } \\ \text { Social Security, Unemployment \& Labor: } & \$ 1.28 \text { trillion }\end{array}$

In addition to the federal government, "[t]he magnitude of state and local government procurement is staggering." $" 195$

[A]mong the 50 states, six territories, and 87,525 local governments, state and local government procurement spending may be roughly valued at approximately $\$ 1.5$ trillion annually for the purchase of goods, supplies, equipment, services, and construction. .... The unprecedented growth of state and local procurement markets can be attributed largely to the federal government's policies shifting program responsibilities more and more to the states. State and local governments have the capacity to impact and drive public policy because of spending directed at implementing collateral policies such as sustainable procurement. ${ }^{196}$

By some measures, combining all local, state, and federal purchasing, public spending may even reach up to $40 \%$ of GDP in the U.S. and $45 \%$ in the EU. ${ }^{197}$

\footnotetext{
${ }^{193}$ Light, 'Public and Private Procurement in Environmental Governance' (n 3$) 5$ (citing Office of Management and Budget, 'Office of Federal Procurement Policy' $<$ https://www.whitehouse.gov/omb/procurement_mission>.

${ }^{194}$ Nat'l Priorities Project (n 192).

${ }^{195}$ Danielle M Conway, 'Sustainable Procurement Policies and Practices at the State and Local Government Level' in Keith H Hirokawa and Patricia E Salkin (eds), Greening Local Government: Legal Strategies for Promoting Sustainability, Efficiency, and Fiscal Savings (ABA 2012) 43.

196 ibid 44.

${ }^{197}$ Clune, 'A Comparative Law Analysis of the Use of State-Level Green Public Procurement in the European Union and the United States' (n 31) 4 (internal citations omitted).
} 


\subsection{The Economic Power of EU Public Procurement}

Public purchasing represents huge potential for sustainable development. Public authorities are major consumers in Europe, accounting for, according to a 2008 publication, $16 \%$ of the EU's GDP. ${ }^{198}$ Even in Finland, which is a relatively small Member State, public purchasing is annually around $€ 14.1$ billion (14 percent of GDP). ${ }^{199}$ Evidence suggests that the economic power of public procurement has remained steady over time as each year more than 250,000 public authorities in the EU spend around $14 \%$ of GDP on purchasing services, works, or supplies, ${ }^{200}$ equivalent to around $€ 2$ trillion (according to a 2015 report). ${ }^{201}$ In some EU countries in addition to Finland, public procurement expenditures exceed $15 \%$ of GDP, including Germany (15\%), the Netherlands (20\%), and Sweden (16\%). ${ }^{202}$

Three product groups generally represent the biggest shares of GPP-affected national budgets in Europe: construction, transportation, and office information technology. ${ }^{203}$ Thus, these are the sectors that may provide for focused use of GPP as they exert a large impact on the market. Other major GPP priority groups for EU Member States include cleaning products and services, copying and graph paper, furniture, food and catering services, electricity, and textiles. ${ }^{204}$ For example, in the UK, it is estimated that the public sector serves around 3.5 million meals per weekday, spending around $€ 2.3$ billion each year

\footnotetext{
${ }^{198}$ Ekroos (n 80) 425; PSRF Mathijsen (ed), A Guide to European Union Law (9th edn, Street \& Maxwell 2007) 267.

${ }^{199}$ Ekroos (n 80) 425.

${ }^{200}$ Commission, 'Public Procurement' $<$ https://ec.europa.eu/growth/single-market/public-procurement_en> accessed 17 Apr 2018; Eur Parliament, Directorate-General for Internal Policies (provided by Policy Department A at the request of the Committee on the Environment, Public Health and Food Safety (ENVI)), 'Green Public Procurement and the EU Action Plan for the Circular Economy' (May 2017) ('Green Public Procurement and the EU Action Plan for the Circular Economy') 5.

${ }^{201}$ Abby Semple, 'The Link to the Subject Matter: A Glass Ceiling for Sustainable Public Contracts?' in Beate Sjåfjell and Anja Wiesbrock (eds), Sustainable Public Procurement Under EU Law: New Perspectives as Stakeholder (Cambridge 2016) 54 ("The approximately $€ 2$ trillion spent by the public sector on goods and services was repeatedly invoked as if it were a fungible asset, rather than being extremely dispersed and variable.") ('Glass Ceiling').

${ }^{202}$ Eur Parliament, 'Green Public Procurement and the EU Action Plan for the Circular Economy' (n 200) 95, Annex A.

${ }^{203}$ Walter Kahlenborn and others, Strategic Use of Public Procurement in Europe, Final Report to the European Commission, MARKT/2010/02/C (2011) vi-vii (Strategic Use of Public Procurement in Europe).

204 ibid 24.
} 
with $50 \%$ in the schools (2007 figures). ${ }^{205}$ The city of Malmö, Sweden (population 300,000), offers 35,000 lunches per day in its schools alone. ${ }^{206}$

Different EU countries have different GPP targets and historical records of fostering GPP. Based on the targets for different government levels, GPP budgets range from $€ 321.36$ million (Belgium - equal to $3.6 \%$ of total public procurement) and $€ 327.98$ million (Slovakia - 7.1\%) to $€ 812.65$ million (Finland $-14.8 \%$ ) and $€ 3.22$ billion (the Netherlands - 34.8\%). ${ }^{207}$ According to numerous studies from the mid-2000s, seven countries (Austria, Denmark, Finland, Germany, Netherlands, Sweden, and UK - the so-called Green-7) implemented more elements of environmentally friendly public procurement (i.e., having more tenders with green criteria, around 40-70\%) than their EU peers. ${ }^{208}$ Two EU Member States, Sweden and Germany, had been very "green," with environmental specifications in just over 60 percent of tender documents. ${ }^{209}$

Over time, we have seen new countries prioritize GPP, improvement even in high-ranking countries, and ambitious national GPP goals. In a 2010 report to the European Commission, it was noted that Denmark, the Netherlands, Norway, Sweden, and the UK stood out as front-runners on GPP, with longstanding policies of compulsory elements, elaborate criteria schemes, institutionalized and intensive use of GPP requirements in their contracts, and proactive capacity-building efforts. ${ }^{210}$ The Netherlands and Finland have set ambitious specific government level targets and apply them not only to the central government; both countries have also targets which increase progressively over time and aim to achieve 100\% GPP at the central level. (Sweden and Cyprus set individual targets that are of a qualitative nature and hence are not discussed in this way). ${ }^{211}$

On average, contracting authorizes use technical specifications most often $(66 \%)$ as the tender section for GPP, followed by the award criteria (45\%) and the requirements for technical and/or professional ability (44\%). The introduction of the tender is used by only $11 \%$ of the time. ${ }^{212}$ The GPP leaders (Denmark, the Netherlands, Norway, Sweden, and the UK) use most of the

\footnotetext{
${ }^{205}$ Foodlinks, Revaluing Public Sector Food Procurement in Europe: An Action Plan for Sustainability (2013) $11<\mathrm{http} / / / \mathrm{www}$. foodlinkscommunity.net/fileadmin/documents_organicresearch/foodlinks/publications/Foodlinks_report_low.pdf $>$.

206 ibid 13.

${ }^{207}$ Kahlenborn (n 203) vi.

${ }^{208}$ Ekroos (n 80) 426; McCrudden, Buying Social Justice: Equality, Government Procurement, and Legal Change (n 78) 398.

${ }^{209}$ Ekroos (n 80) 426.

${ }^{210}$ Kahlenborn (n 203) iii.

211 ibid.

212 ibid viii.
} 
sections and also use them more often than the other Member States. They also more often use the introduction $(22 \%$ vs. $7 \%)$, the award criteria $(54 \%$ vs. $32 \%$ ) and the requirement for technical and professional ability (56\% vs. $44 \%)$. The other Member States predominantly include the GPP requirements in technical specifications, even more so than the GPP leaders (67\% vs. $59 \%$ ). The use by some contracting authorities of green criteria in addition to technical specifications is possibly an indication that such contracting authorities are more confident in applying GPP, whereas those that use only technical specifications do so because the (minimum) GPP criteria have been predefined, and they are sure they are legally valid. ${ }^{213}$

A 2012 study found that $55 \%$ of contracting authorities surveyed included at least one GPP criteria in the last contract awarded, and 54\% of local governments and $41 \%$ of central governments reported that they "always or often" include environmental criteria in their tenders. ${ }^{214}$ The evidence shows that GPP, prior to the implementation of the 2014 Public Sector Directive, has been effective. The empirical findings clearly suggest that including environmental policy goals in the tender leads bidding suppliers to integrate the required environmental criteria, and the impact of including environmental policy goals in the tender in changing the supplier's behavior to greener offers is regarded as moderate. ${ }^{215}$ From the analysis of procurement files in Austria, Germany, the Netherlands, and the United Kingdom, it can be stated that integrating additional objectives into public procurement with regard to GPP has a measurable and significant impact on procurement outcomes. ${ }^{216}$

\subsection{Summary}

The economic power of public procurement is significant. In the U.S., federal spending accounts for nearly $\$ 4$ trillion, over $20 \%$ of gross domestic product (GDP). In Europe, public authorities account for about 16\% of the EU's GDP. Thus, public purchasing can potentially have a discernible impact on environmental interests and sustainable development. The challenging inquiry, once procurement outcomes are changed, is whether GPP policies exert a discerni-

\footnotetext{
213 ibid.

${ }^{214}$ Center for Eur Policy Studies and Council of Eur, The Uptake of Green Public Procurement in the EU27 (2012) vii; Dragos, 'Sustainable Public Procurement in the EU: Experiences and Prospects' (n 90) 311-13.

215 Kahlenborn (n 203) 109.

216 ibid 137.
} 
ble "demand pull" - encouraging broader adoption of environmental standards and/or lower prices for more environmentally friendly goods? ${ }^{217}$ However, before this can determined, governments will have to encourage GPP (e.g., the EU's Public Sector Directive and U.S. Executive Orders discussed below), and cross-cutting mechanisms and methodologies must exist for both private economic entities and public institutions to effectively adopt environmental standards (e.g., eco-labels and life-cycle costing).

${ }^{217}$ Semple, 'Glass Ceiling' (n 201) 73. 


\section{The U.S. Market Participant Exception, Public Procurement \& The Environment}

\subsection{Introduction}

The notion of federalism ${ }^{218}$ allows American states, as sovereign entities, to pursue legislation and policies that further state interests. The Tenth Amendment to the U.S. Constitution states, "The powers not delegated to the United States by the Constitution, nor prohibited by it to the States, are reserved to the States respectively, or to the people." ${ }^{119}$ This remains true so long as state regulation is not pre-empted by federal (i.e., national) legislation under the Supremacy Clause. ${ }^{20}$ The Supremacy Clause of the U.S. Constitution states, "This Constitution, and the Laws of the United States which shall be made in Pursuance thereof; and all Treaties made, or which shall be made, under the Authority of the United States, shall be the supreme Law of the Land; and the Judges in every State shall be bound thereby, any Thing in the Constitution or Laws of any State to the Contrary notwithstanding."

In the United States, the term "environmental federalism" refers to the ability of states to establish more rigorous or creative environmental protection legislation than that of the national government. ${ }^{221}$ This idea is not new. In his dissenting opinion in New State Ice Company v. Liebmann, U.S. Supreme Court Justice Louis Brandeis stated, "[i]t is one of the happy incidents of the federal system that a single courageous State may, if its citizens choose, serve as a laboratory; and try novel social and economic experiments without risk to the rest of the country." 222

These "experiments" can be crafted by state legislatures, with the legislation being interpreted by the entire layer of state courts that are bound to state law, state constitutions, and, ultimately, the U.S. Constitution. The number of

\footnotetext{
218 John O McGinnis and Ilya Somin, 'Federalism vs. States' Rights: A Defense of Judicial Review in a Federal System' (2004) 99 Northwestern U L Rev 89.

${ }^{219}$ US Const amend X.

${ }^{220}$ US Const art VI, $\mathrm{cl} 2$.

${ }^{221}$ Robert V Percival, 'Environmental Federalism: Historical Roots and Contemporary Models' (1995) 54 Maryland L Rev 1141.
}

${ }^{222}$ New State Ice Co v Liebmann 285 US 262, 311 (1932) (Brandeis, J, dissenting). 
cases filed in state courts far exceeds the docket of the federal court system. However, state law can be challenged for violating federal law.

In the U.S., laws that require, or provide incentives for, purchasing products produced within a defined geographic boundary or products meeting certain environmental standards may be, "vulnerable to challenge [likely in federal court] under the U.S. Constitution's restrictions on local and state laws that discriminate against goods and commerce from other states, known as the dormant Commerce Clause doctrine." ${ }^{223}$ However, American states may use the "market participant exception" to apply such constraints or conditions to direct government purchasing. The exception draws a distinction between state governments acting as market regulators (such as when imposing a tax or banning an unhealthy ingredient) and acting as market participant (by directly buying or selling goods). ${ }^{224}$ "In other words, state and local governments can act as any private buyer or seller would in deciding with whom and on what terms they will deal." 225

Under the principles of federalism, for example, a state has the right to create regulations requiring state governmental entities to give geographic preference to local businesses, or even minority owned businesses. A state, as a regulator however, may also have the ability to pass even-handed regulations outside the context of public procurement to promote environmental interests in the state. For example, in Minnesota v. Clover Leaf Creamery Company, the U.S. Supreme Court upheld a Minnesota state law prohibiting the use of non-recyclable plastic containers for milk as non-discriminatory and valid. ${ }^{226}$ In these cases, a court will balance the impact of a statute on interstate commerce against the state's justifications for the statute..$^{227}$

As the environmental (and economic) benefits of ecologically preferential characteristics become more obvious, ${ }^{228}$ states and local governments are considering the implementation of such regulations and legislation; yet fears of constitutional challenges and retaliatory measures from other states may prevent legislative passage. Cities and counties have expressed concern about considering any local purchase policies due to legal questions about the

${ }^{223}$ Brannon P Denning and others, 'Laws to Require Purchase of Locally Grown Food and Constitutional Limits on State and Local Government: Suggestions for Policymakers and Advocates' (2010) 1 J Agriculture, Food Systems, and Community Development 139, 139; Amy S Ackerman, 'Buy Healthy, Buy Local: An Analysis of Potential Legal Challenges to State and Local Government Local Purchase Preferences’ (Fall 2011) 43 The Urban Lawyer 1015.

${ }^{224}$ Denning (n 223) 142.

225 ibid.

${ }^{226}$ Minnesota v Clover Leaf Creamery Co 449 US 456, 461 (1981).

${ }^{227}$ Dan T Coenen, 'Untangling the Market-Participant Exception to the Dormant Commerce Clause' (1989) 88 Michigan L Rev 395, 399 n.26.

${ }^{228}$ Jason J Czarnezki, 'Food, Law \& the Environment: Informational and Structural Changes for a Sustainable Food System' (2011) 31 Utah Environmental L Rev 263. 
dormant commerce clause and a lack of clarity on how to avoid legal challenges to policy decisions. ${ }^{229}$

This Part 6 defines the market participant exception under U.S. law; offers examples of how American states are using the exception (in the context of local food purchasing which is perceived as having both environmental and local economic benefits); offers guidance for how policy makers, if they desire, can more effectively use the market participant exception to support the purchase of local foods and environmentally sound products; and considers the legality of legislation to promote environmental considerations in purchasing beyond the context of public procurement. Finally, Part 6 summarizes green public procurement efforts by American states and the U.S. federal government, which lags behind the efforts of the states. This is an inverted policy outcome compared to the European Union, in that American federal law, unlike EU law, does not dictate the parameters under which states can use GPP, and implementation of GPP by U.S. government lags behind EU Member States.

\subsection{What is the Market Participant Exception?}

\subsubsection{Introduction to Legal Basis for Market Participant Exception}

The U.S. Constitution delegates authority to the Congress "[t]o regulate commerce ... among the several states." ${ }^{230}$ While, in the federal system, the individual states maintain sovereignty, a judicially created dormant commerce clause doctrine limits state action that may place burdens on successful interstate commerce. Despite this, American states maintain their ability to act as consumers via public procurement, and may pass generally applicable legislation that benefits state interests. The "market participant exception" allows states to restrict interstate trade when acting as purchasers or sellers rather than as regulators.

\subsubsection{The Commerce Clause}

The Commerce Clause, found in Article I of the U.S Constitution, grants Congress the power to regulate interstate commerce. ${ }^{231}$ In the seminal case Gibbons v. Ogden, ${ }^{232}$ the U.S. Supreme Court concluded that a 1793 federal law

\footnotetext{
${ }^{229}$ See Denning (n 223) 140.

${ }^{230}$ US Const art I, § 8, cl 3.

231 ibid.

${ }^{232}$ Gibbons v Ogden 22 US 1 (1824).
} 
authorizing the operation a ferry in New York waters was valid and determined that federal law preempted the New York granted monopoly to another ferry company. ${ }^{233}$ The Court also found the New York monopoly to be an impermissible restriction of interstate commerce. ${ }^{234}$

Three main conclusions survive from Gibbons: 1) "commerce" describes the commercial intercourse between nations, and parts of nations, in all its forms, including navigation; 235 and 2) "among the states" means "that commerce which concerns more States than one... The completely internal commerce of a State, then, may be considered as reserved for the State itself;" ${ }^{236}$ but, 3) that state sovereignty and the Tenth Amendment do not limit Congress's powers. ${ }^{237}$ "This power, like all others vested in Congress, is complete in itself, may be exercised to its utmost extent, and acknowledges no limitations, other than are prescribed in the constitution." ${ }^{238}$

In Wickard v. Filburn, ${ }^{239}$ the U.S. Supreme Court cemented the expansive power and scope of the federal government in regulating interstate commerce. The Court upheld the application of the Agricultural Adjustment Act, and the resulting wheat production allotment for individual farmers, to a farmer who grew wheat primarily for his own consumption. ${ }^{240}$ The farmer argued that this was not part of interstate commerce, and therefore beyond the federal government's regulatory authority under the Commerce Clause. ${ }^{241}$ The Court ruled that, in the aggregate, homegrown wheat can have a substantial effect on interstate commerce, ${ }^{242}$ as the farmer's "own contribution to the demand for wheat may be trivial by itself [, it] is not enough to remove him from the scope of federal regulation where, as here, his contribution, taken together with that of many others similarly situated, is far from trivial." ${ }^{243}$

The Court has found very few federal laws to unconstitutionally exceed the scope of Congress's power pursuant to the Commerce Clause. In United States v. Lopez, the U.S. Supreme Court declared unconstitutional the Gun-Free School Zones Act of 1990, which made it a federal crime to have a gun within

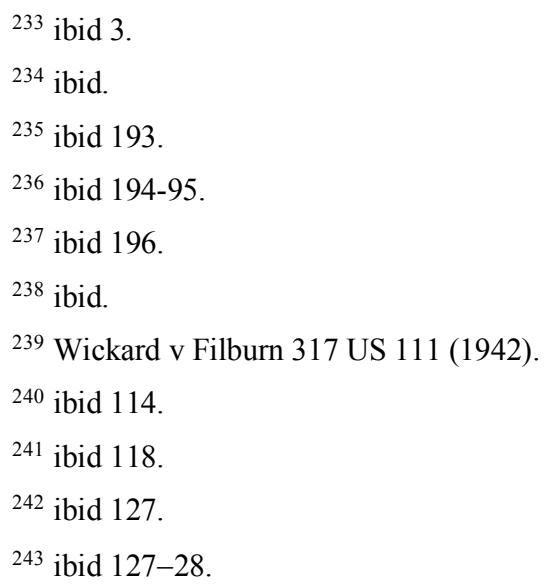


1,000 feet of a school, stating that the relationship of the law to interstate commerce was too tangential and uncertain to uphold the law as a valid exercise of Congress's commerce power. ${ }^{244}$ Similarly, in United States v. Morrison, the Court held that that Congress did not have authority under the Commerce Clause to regulate gender-motivated violence and struck down Violence Against Women Act of 1994. ${ }^{245}$

Despite the holdings of these exceptional cases, the U.S. Supreme Court continues to broadly construe the power of the federal government pursuant to the Commerce Clause. For example, in Pierce County, Washington. v. Guillen, the Court unanimously reaffirmed broad authority for Congress to legislate concerning road safety as part of its power to regulate the channels of interstate commerce, upholding controversial non-disclosure provisions of the Hazard Elimination Program that provides state governments with funding to improve the most dangerous sections of their roads. ${ }^{246}$ Similarly, in Gonzales v. Raich, the Court held that Congress may constitutionally use its power to regulate commerce among the states to prohibit the cultivation and possession of small amounts of marijuana for medicinal purposes. ${ }^{247}$

\subsubsection{The Dormant Commerce Clause}

While the Commerce Clause functions to authorize congressional legislation related to interstate commerce, it also serves the function of limiting state and local law that may restrain interstate commerce. This so-called dormant commerce clause is the judicially created principle, not explicitly stated in the U.S. Constitution, though inferred from the Commerce Clause, "that state and local laws are unconstitutional if they place an undue burden on interstate commerce." ${ }^{248}$

\footnotetext{
${ }^{244}$ US v Lopez 514 US 549 (1995).

${ }^{245}$ US v Morrison 529 US 598 (2000).

${ }^{246}$ Pierce County, Washington v Guillen 537 US 129 (2003).

${ }^{247}$ Gonzales v Raich 545 US 1 (2005).

${ }^{248}$ Erwin Chemerinsky, Constitutional Law: Principles and Policies (Aspen 2006) 391; See also Coenen (n 227) 399 n.26 (1989) (citing Dean Milk Co v City of Madison 340 US 349, 353 (1951)) ("The leading modern statement of the Court's dormant commerce clause 'balancing' test appears in Pike v. Bruce Church, Inc., 397 U.S. 137 (1970).”).
} 
A two-part test is used by courts to determine if a law or regulation violates the dormant commerce clause. ${ }^{249}$ First, the court asks: Is the law facially discriminatory, ${ }^{250}$ or is the purpose or effect of the law discriminatory? ${ }^{251}$ The court considers whether the state law discriminates against individuals or entities not from the state that passed the legislation, whether it treats all citizens alike regardless of residence, ${ }^{252}$ or whether it has a discriminatory impact. ${ }^{253}$ These state laws that are "simple economic protectionism" are essentially per se invalid. ${ }^{254}$ Second, if the regulation at issue is not invalidated on the basis of facial discrimination or discriminatory impact, the court conducts a judicially-developed balancing test whereupon it weighs the state's interest in promulgating a statute against the burden that the statute imposes on interstate commerce. ${ }^{255}$ In other words, does the state law impose "an undue burden on interstate commerce"? ${ }^{256}$

Under part one of the test, in cases where state law overtly discriminates against out-of-state economic interests through means such as a tariff, tax, quota, or outright embargo, the Supreme Court has routinely adopted an almost per se rule of invalidity. ${ }^{257}$ The Supreme Court has struck down laws as discriminatory under the dormant commerce clause when the law draws an express distinction between in-state and out-of-state entities such as prohibiting out-of-state ownership of certain business interests, or when there are price restrictions on out-of-state products. In Lewis v. BT Investment Managers, Inc., the Court declared unconstitutional a state law that prevented out-of-state banks from owning investment advisory businesses within the state. ${ }^{258}$ In Baldwin v. G.A.F. Seelig, the Court declared unconstitutional a state law that

${ }^{249}$ United Haulers Association, Inc v Oneida-Herkimer Solid Waste Management Authority 550 US 330, 338, 345, 347 (2007); C \& A Carbone, Inc v Town of Clarkstown, NY 511 US 383, 389-90 (1994) (employing a two-tiered dormant commerce clause test).

${ }^{250}$ City of Philadelphia v New Jersey 437 US 617, 628 (1978).

${ }^{251}$ Dean Milk Co v City of Madison, Wisconsin 340 US 349, 354, (1951) (holding that an evenhanded local milk ordinance "in practical effect" discriminated against out-of-state milk suppliers).

252 Pike v Bruce Church, Inc 397 US 137, 142 (1970).

${ }^{253}$ C \& A Carbone (n 249) 383; Hunt v. Washington State Apple Advertising Commission 432 US 333 (1977).

${ }^{254}$ Coenen (n 227) 399 n.22, 23 (citing City of Philadelphia (n 250) 623-24; accord BrownForman Distillers Corp v NY State Liquor Authority 476 US 573, 579 (1986); City of Philadelphia (n 250) 624; Hughes v Oklahoma, 441 US 322, 336-37 (1979)).

${ }^{255}$ Pike (n 252) 142.

${ }^{256}$ Coenen (n 227) 399 n.26 (citing Dean Milk (n 248) 353).

${ }^{257}$ Granholm v Heald 544 US 460, 476 (2005) (quoting City of Philadelphia (n 250) 624) ("State laws that discriminate against interstate commerce face 'a virtually per se rule of invalidity."”).

${ }^{258}$ Lewis v BT Investment Managers, Inc 447 US 27, 44 (1978). 
restricted prices of milk produced out-of-state and prevented it from being sold at a price lower than in-state milk. ${ }^{259}$

Local regulations also cannot discriminate against both out-of-state and instate ventures in the interest of local economic protectionism. In Dean Milk Co. v. City of Madison, Wis., the Court reviewed a city ordinance that required that all milk sold in the city had to pasteurized within five miles of the city. ${ }^{260}$ In Dean Milk Co., the Court declared, "In thus erecting an economic barrier protecting a major local industry against competition from without the state, Madison plainly discriminates against interstate commerce." ${ }^{261}$ The Court held the fact that Wisconsin milk from outside the Madison area was also subjected to the same proscription as that moving in interstate commerce as "immaterial." $" 262$

If the law is facially neutral, but the purpose or the effect is to discriminate, then it will be found unconstitutional. Discriminatory impact is sufficient for invalidation. ${ }^{263}$ In Washington State Apple Advertising Commission, a North Carolina law required that all closed containers of apples sold or shipped into the state bear "no grade other than the applicable U.S. grade or standard." The law was facially neutral in that all apples sold in the state-whether produced from within or from out-of-state-had to comply with the rule. This notwithstanding, the Court held that the law was discriminatory because of its effect on the sale of Washington apples. ${ }^{265}$ Washington had a system for grading apples that was different from the federal standard, so the law effectively prohibited Washington growers and dealers from marketing apples under their state's existing grades. The Court deemed this an unconstitutional "leveling effect which insidiously operate[d] to the advantage of local apple producers." 266

If the law or regulation at issue is not found to be facially discriminatory and the purpose or effect of the law is not discriminatory, then the court will move to the second part of the test. The court conducts a balancing test weighing the state interest in promulgating a statute against the burden that the law

\footnotetext{
${ }^{259}$ Baldwin v GAF Seelig, Inc 294 US 511, 521 (1935).

260 Dean Milk (n 248) 349.

261 ibid 354.

262 ibid 354 n. 4.

${ }^{263}$ See, e.g., C \& A Carbone (n 249) 383; Hunt (n 253) 333 (finding discrimination based on the disparate impact of a law against out-of-staters).

264 ibid 339 (citing NC Gen Stat § 106-189.1 (1973)).

265 ibid 350.

266 ibid 351.
} 
imposes on interstate commerce. ${ }^{267}$ "Where the statute regulates even-handedly to effectuate a legitimate local public interest, and its effects on interstate commerce are only incidental, it will be upheld unless the burden imposed on such commerce is clearly excessive in relation to the putative local benefits. ${ }^{\prime 268}$

While courts have significant discretion, they generally uphold state laws once the law has already been determined to be non-discriminatory. For example, in Minnesota v. Clover Leaf Creamery Co., the Court upheld a state law prohibiting the use of non-recyclable plastic containers for milk, ${ }^{269}$ since the environmental benefits of the law outweighed any harms to interstate commerce. ${ }^{270}$ Similarly, in Maine v. Taylor, the Court upheld a state statute banning the import of out-of-state minnow fish. "The Commerce Clause significantly limits the ability of States and localities to regulate or otherwise burden the flow of interstate commerce, but it does not elevate free trade above all other values."'271 In Taylor, the Court found that Maine's ban on the importation of live baitfish was well within its regulatory authority to protect the health and safety of its citizens and the integrity of its natural resources. ${ }^{272}$

That said, despite a finding that the state law is non-discriminatory, the law may place a significant burden on interstate commerce and, thus, be found unconstitutional. For example, in Bibb v. Navajo Freight Lines, the Court declared unconstitutional a state law that required all trucks in the state use curved mudguards to prevent spatter and enhance road safety. ${ }^{273}$ The Court found the law to substantially burden interstate commerce because straight mudguards were legal in 45 other states and curved mudguards were illegal in one other state. ${ }^{274}$ Furthermore, since the trial court found that curved mud flaps had no safety benefits over straight ones and may create "hazards previously unknown" by increasing the heat around a truck's tires, the Court declared the law unconstitutional. ${ }^{275}$ The Court described it as "one of those

\footnotetext{
${ }^{267}$ Pike (n 252) 142.

268 ibid (citing Huron Portland Cement Co v City of Detroit 362 US 440, 443 (1960)).

${ }^{269}$ Clover Leaf Creamery Co (n 226) 461.

270 ibid 473 ("Even granting that the out-of-state plastics industry is burdened relatively more heavily than the Minnesota pulpwood industry, we find that this burden is not 'clearly excessive' in light of the substantial state interest in promoting conservation of energy and other natural resources ....”.).

${ }^{271}$ Maine v Taylor 477 US 131, 151 (1986).

272 ibid.

${ }^{273}$ Bibb v Navajo Freight Lines 359 US 520, 530 (1959).

274 ibid 523.

275 ibid 525.
} 
cases - few in number - where local safety measures that are nondiscriminatory place an unconstitutional burden on interstate commerce. ${ }^{276}$

Despite the existence of the dormant commerce clause, two exceptions exist for constitutional permissibility of discriminatory law or practices in commerce. First, "[e]ven a clearly unconstitutional, discriminatory state law will be allowed if approved by Congress because Congress has plenary power to regulate commerce among the states." ${ }^{277}$ Second, under the market participant exception, "[a] state may favor its own citizens in receiving benefits from government programs or in dealing with government-owned businesses." 278 "The federal courts of appeal have rejected most Commerce Clause challenges to in-state preference laws, holding that the market participant exception applies." ${ }^{279}$

\subsubsection{The Market Participant Exception}

The market participant exception may prove to be a useful tool for states to encourage the production of locally produced or environmentally preferred goods and services. "The market participant exception provides that a state may favor its own citizens in dealing with government-owned business and in receiving benefits from government programs." ${ }^{280}$ Thus, a state, when acting as a consumer in the market or a "market participant," rather than as a "market regulator," can make restrictive choices in public procurement that might otherwise be found to violate the Commerce Clause of the U.S. Constitution. ${ }^{281}$

In Hughes v. Alexandria Scrap Corporation, the Supreme Court, in upholding a state law that required more extensive documentation when out-of-state scrap processors purchased junk cars, first recognized the market participant exception, stating that none of the purposes of the Commerce Clause prohibits a State, in the absence of congressional action, from participating in the market and exercising the right to favor its own citizens over others. ${ }^{282}$ Four years later, the Court held in Reeves, Inc. v. Stake that "[t]here is no indication of a

\footnotetext{
276 ibid 529.

${ }^{277}$ Chemerinsky (n 248) 449.

278 ibid.

279 Ackerman (n 223) 1020.

${ }^{280}$ Chemerinsky (n 248) 451. See also Coenen (n 227) for a comprehensive overview of the market participant exception.

${ }^{281}$ Coenen (n 227) 397 (citing Reeves, Inc v Stake 447 US 429, 436 (1980)); Richard H Seamon, Note, 'The Market Participant Test in Dormant Commerce Clause Analysis-Protecting Protectionism?'(1995) 1985 Duke LJ 697, 697-98 (“. . . certain state actions taking the form of market participation will be summarily upheld that would, in a different form, be summarily struck down as invalid per se.”)).
}

${ }^{282}$ Hughes v Alexandria Scrap Corp 426 US 794, 810 (1976). 
constitutional plan to limit the ability of the States themselves to operate freely in the free market." ${ }^{283}$

The market participant exception suggests that states can favor its own citizens and local businesses (e.g., local food producers and processors) when wanting to encourage local interests and when engaged in the purchasing itself. For example, in White v. Massachusetts Council of Construction Employ$e r s,{ }^{284}$ the Supreme Court upheld a city's ordinance that required all construction projects financed by the city to use a workforce comprised of at least 50 percent residents of the city. ${ }^{285}$ In upholding the ordinance, the Court noted that "Alexandria Scrap and Reeves ... stand for the proposition that when a state or local government enters the market as a participant it is not subject to the restraints of the Commerce Clause." ${ }^{.286}$ Invoking the market participant exception, the U.S. Supreme Court has "shielded from commerce clause attack blatant favoritism of local interests when a state or municipality buys printing services, sells cement, purchases goods, or hires workers." ${ }^{287}$

While the market participant exception makes valid state discrimination when acting in the marketplace, this seemingly per se validity does not always operate.

[E]ven if a state looks quite like a buyer or seller choosing trading partners, the Court has left itself room not to treat the state as such. The Court may accomplish this result by recognizing an "exception" to the "general rule" or by characterizing the state as a "market regulator" notwithstanding its superficial appearance as a "market participant." Both roads lead to the same place. The key point is that they remain open. ${ }^{288}$

One important limitation that the Court has imposed on the scope of the market participant exception is that state businesses may favor in-state producers and vendors, but they may not attach conditions to a sale that discriminates against interstate commerce. ${ }^{289}$ For example, a state can require that all government agencies purchase apples grown within the state, but it cannot require

\footnotetext{
${ }^{283}$ Reeves, Inc (n 281) 437.

${ }^{284}$ White v Massachusetts Council of Construction Employers 460 US 204 (1983).

285 ibid 206.

286 ibid 208.

${ }^{287}$ Coenen (n 227) 397 (citing American Yearbook Co v Askew 339 F Supp 719 (Middle District Florida 1972) (three-judge court), affd mem, 409 US 904 (1973); Reeves, Inc (n 281) 446; Alexandria Scrap Corp (n 282) 794; White (n 284) 204).

288 ibid 404-05 (internal citations omitted).

${ }^{289}$ South-Central Timber Development Inc v Wunnicke 467 US 82, 98 (1984) (plurality opinion) (drawing a distinction between the ability of a state to prefer its own citizens in the "initial disposition of goods when it is a market participant" and a "State's attachment of restrictions on dispositions subsequent to the goods coming to rest in private hands").
} 
that any purchaser (in or out-of-state) have the apples processed in the state before they can be exported.

Thus, despite years of judicial interpretation, "[t]he precise contours of the market participant doctrine have yet to be established." ${ }^{290}$ What exactly comprises market participation versus market regulation is still being explored in the realm of climate change, electric power regulation, and more recently, public food procurement. ${ }^{291}$ It is clear that states and local governments can rely on the market participant exception to enact laws that allow public procurement agencies to give preference to local goods.

But more generally, when courts consider whether any activity falls within the market participant exception, courts consider whether the program reflects an effort of state government to favor state residents when selecting the recipients of the state's own resources; whether the program is consistent with the values of federalism, local experimentation, and responsiveness to local concerns; to what extent the program threatens the underlying commerce clause values of a free market; and whether the state appears to be "participating in" rather than "regulating" the market. ${ }^{292}$

Even when falling into the contours of the market participant exception, there are risks to states invoking it in a discriminatory fashion. It may induce neighboring states to retaliate and undermine current interstate trade. "Because such protectionist policies have detrimental effects on out-of-state foreign bidders, negatively impacted jurisdictions ... sometimes employ reciprocal or retaliatory responses to exclude or inhibit bidders from the 'offending' state from participating in procurement. ${ }^{" 293}$ For example, the state of Pennsylvania took an eye-for-an-eye approach, enacting a reciprocal preference against states that institute preference with respect to supplies, equipment, or materials produced, manufactured, mined, or grown in that state. ${ }^{294}$ Under the statute, "[t]he amount of the preference shall be equal to the amount of the

290 ibid 93.

${ }^{291}$ Michael Burger, 'It's Not Easy Being Green: Local Initiatives, Preemption Problems, and the Market Participant Exception' (2010) 78 U Cincinnati L Rev 835, 835 (discussing whether the market participant exception should be interpreted to exempt local climate change and sustainability initiatives from the "ceilings" imposed by existing environmental laws); Andrew F Adams, 'It's Getting Hot in Here: California Senate Bill 1368 and the Dormant Commerce Clause' (2011) 1 San Diego J Climate and Energy L 287, 289-90 (addressing whether a local California climate bill will hold up to a commerce clause challenge under the market participant exception); New England Power Co v New Hampshire 455 US 331, 338 (1982) (declaring unconstitutional a law that limited the ability of electricity to be shipped out of the state without the permission of the state's public utility commission); Denning (n 223) 142-43 (discussing states' use of the market participant exception to pass local food legislation).

292 Coenen (n 227) 441.

${ }^{293}$ Kingsley S Osei, 'The Best of Both Worlds: Reciprocal Preference and Punitive Retaliation in Public Contracts' (2011) 40 Public Contract LJ 715, 716 (2011).

${ }^{294}$ Pennsylvania Reciprocal Limitations Act, 62 PA Const Stat Ann $§ 107$ (West 1986). 
preference applied by the other state for that particular supply." 295 New York uses a penalty provision, applying retaliatory sanctions against bidders with a principle place of business located in a state that penalizes New York vendors through bid price distortions and procurement preferences. ${ }^{296}$ The New York State Commissioner of Economic Development developed a list of six states as jurisdictions that discriminate against New York bidders in the procurement of commodities or services. ${ }^{297}$ Pursuant to the statute, New York agencies, public authorities, and public benefit corporations are required to deny the award of contracts to businesses from these jurisdictions. ${ }^{298}$ Thus, there are both potential costs and benefits when invoking the market participant exception.

\subsection{The Environment, Food \& the Market Participant Exception}

The mechanisms by which American states and localities define the "procurement regulatory environment" are varied, ranging from legislation to administrative law and policy statements. All American states have procurement laws and policies in some form. However, the regulatory environment is quite variable with some states having elaborate procurement policies codified by statute and other states having basic procurement laws leaving details of the procurement process to the administrative code developed by state agencies. ${ }^{299}$ There are significant consequences to these approaches. Laws take acts of the state legislature to alter, a time consuming process that makes it difficult to modify the procurement regulatory environment when market conditions or other matters make it necessary to do so. ${ }^{300}$ On the other hand, if regulations are contained in administrative code, action by state legislatures is not necessary and the provisions be modified via a public review and comment process taking a much shorter period of time (months versus years). ${ }^{301}$ Through this variety of mechanisms, it has been state and local governments, not the federal

\footnotetext{
295 ibid.

${ }^{296}$ New York State Omnibus Procurement Act (1994) (codified as amended at 1994 NY Laws 3553 and 2000 NY Laws 3032).

297 ibid.

298 ibid.

299 National Association of State Procurement Officials (NASPO), Executive Summary, NASPO 2009 Survey of State Government Purchasing Practices Survey Questions (2009) 6.

300 ibid.

301 ibid.
} 
government, that have been the key players in green public procurement in the U.S. ${ }^{302}$

"Many state and local governments have adopted environmentally preferable purchasing (EPP) programs in response to executive or legislative environmental and sustainable and sustainability mandates." ${ }^{303}$ For example, by 2010, nearly every state established a program to address environmentally preferable purchasing and/or sustainable procurement. ${ }^{304}$ Conway asserts that state and local governments act as "launch customers" to create markets for innovative green technology, products and services leading towards the promotion of green technology innovation and efficient use of public resources. ${ }^{305}$ Conway laid out a number of strategies whereby states can generally implement green public procurement: ${ }^{306}$

[S]etting specific purchasing targets or identifying preferable products with particular attributes represents a much more aggressive approach to achieving sustainable procurement. For example, the State of Oregon issued executive order 00-07 setting a goal for the state to become sustainable by 2025. To this end, the order directed the Department of Administrative Services to (1) aggressively pursue cooperative purchasing agreements; (2) appoint a Sustainable Supplier Council; (3) work with the Sustainable Supplier Council to develop sustainable purchasing policies, targets, and benchmarks for five product areas; and (4) coordinate efforts to better market Oregon's sustainable products, industries, and services. ${ }^{307}$

Changing organizational behavior and adopting a culture of sustainability among state procurement professionals .... An example of a mandate to change state agency culture in connection with procurement is the State of Washington's executive order 02-03, titled Sustainable Practices by State Agencies. The order provides in its preamble that "state government should model sustainable business practices that contribute to the long-term protection and enhancement of [the] environment, [the] economy and the health of current and future generations" and goes on to direct that "[e]ach state agency shall establish sustainability objectives and prepare a biennial Sustainability Plan to

\footnotetext{
${ }^{302}$ Please note that this thesis provides a valuable compilation of examples of green procurement initiatives by American states, but these lists are not inclusive of all such efforts.

${ }^{303}$ Conway (n 195) 50

304 ibid 46. Currently, at least 31 states are listed as having active green procurement programs and/or activities. National Association of State Procurement Officials, 'States with Green Purchasing Profiles' <http://www.naspo.org/dnn/greenmap/California.aspx> accessed $29 \mathrm{Jul}$ 2019.

305 Conway (n 195) 47.

306 ibid 51-55.

307 ibid 51 (emphasis added).
} 
modify its practices regarding resource consumption; vehicle use; purchase of goods and services; and facility construction, operation and maintenance."’308

[I]ntegrating sustainability throughout the entire acquisition process. ${ }^{309}$

[E]nvironmental and human health issues must be contemplated during the earliest phases of the acquisition planning process. ${ }^{310}$

During acquisition planning, contracting officers generally have the flexibility to determine how to integrate sustainability into an acquisition. ${ }^{311}$

Using some of these principles, states, aware of not just a national, but the global, orientation toward sustainability have, over the past several years, implemented variations of green public procurement.

For example, New Jersey (NJ) implemented green procurement at the state level by initiating a policy regarding energy and water conservation throughout all of the New Jersey Department of Military and Veterans Affairs (DMAVA) facilities. In issuing its "[New Jersey Army National Guard (NJARNG)] Energy and Water Conservation Policy," Governor Christie (NJ) directed all NJ Army National Guard individuals, offices, tenants, leases, and organizations to inaugurate an energy and water conservation program in collaboration with the members of the NJARNG to reduce and manage energy and water consumption within their respective facilities. ${ }^{312}$ The three identified goals of the DMAVA program, which generally reflect the green procurement mission of President Obama's Executive Order (EO) 13693 (discussed below), are: (1) to reform facility operations by enforcing strategies to promote considerable life-cycle cost savings; (2) to increase use of clean and renewable energy; and (3) to reduce emission and overall adverse environmental impact on present actions to mitigate the impact on future generations. ${ }^{313}$ Specifically, Governor Christie's Policy Letter instructs the NJARNG to "promote sustainable acquisition and procurement by ensuring that all equipment, products, and fixtures purchased meet or exceed" existing U.S. Environmental Protection Agency (EPA) standards. ${ }^{314}$

\footnotetext{
308 ibid (alteration in original) (emphasis added).

309 ibid 53 (emphasis added).

${ }^{310}$ Ibid at 54 (emphasis added).

${ }^{311}$ Ibid at 55 (emphasis added).

312 State of New Jersey, 'Tag Policy Letter 15-1, NJARNG Energy and Water Conservation Policy (15 May 2015) ('Tag Policy Letter').

313 ibid.

314 'Tag Policy Letter' (n 312); Energy Star, <http://www.energystar.gov/> accessed $18 \mathrm{Apr}$ 2018; US Environmental Protection Agency, 'WaterSense' $<$ https://www.epa.gov/watersense> accessed 18 Apr 2018.
} 
Other states also have taken strides toward achieving sustainability through self-imposed green procurement programs. Massachusetts, for example, predated New Jersey's action and EO 13693 with a state policy aimed at protecting public health and the environment by promoting the use of clean technologies, recycled materials, and nontoxic products. ${ }^{315}$ In 2009, weeks after Obama's signing of EO 13514 (discussed below), Massachusetts passed Executive Order 515 establishing an Environmental Purchasing Policy whereby all Commonwealth Executive Departments are required to participate. ${ }^{316}$ Targeted purchasers include schools, municipalities, public institutions of higher education, and county governments. Though Massachusetts EO 515 predates EO 13693, it mimics Obama's ambition to implement GPP within government agencies. The goals of Obama's EO 13693 were to be implemented through revision of the Federal Acquisitions Regulations (see Part 6.6 below).

Massachusetts and New Jersey are not alone in the effort to green state and local government. ${ }^{317}$ California mandates a statewide Environmentally Preferable Purchasing program to buy green products and services as ordained through state law. ${ }^{318}$ In 2014, Oregon issued a statewide policy to revise state procurement practices to reduce use of toxic chemicals in products used by state agencies by applying "Green Chemistry" in purchasing. ${ }^{319}$ Colorado offers less comprehensive GPP requirements, narrowly offering only green specifications for purchasing paper. ${ }^{320}$ Arkansas gives preference to products with the highest bio-based composition, which meet or exceed federal standards. ${ }^{321}$ However, while a majority of states have laws, programs and/or guidelines formally intended to mandate, promote, and facilitate statewide GPP, the efforts are varied and inconsistent, with many states not yet having followed the sustainability trend.

Food purchases are a more specific example where states can directly exert their procurement power (in a manner that would be prohibited in the EU), and local food purchases by state actors in the U.S. bridge the gap between supporting local economies and supporting what is at least perceived to be a

${ }^{315}$ Massachusetts Executive Office for Administration and Finance, 'Learn About EPPs and the EPP Purchasing Program' <http://www.mass.gov/anf/budget-taxes-and-procurement/procurement-info-and-res/procurement-prog-and-serv/epp-procurement-prog/learn-aboutepps/\#EO_515> accessed 18 Apr 2018.

${ }^{316}$ Exec Order No 13,514, Federal Leadership in Environmental, Energy, and Economic Performance, 74 Fed Reg 194 (Oct 8, 2009).

${ }^{317}$ Conway (n 195) 45-46.

318 Cal Pub Cont Code $\S 12400-12404$.

319 Green Chemistry Procurement Guidelines, Or Rev Stat $\S$ 279A.140, 279B.205, 184.423(1)(j) (Sept 10, 2014).

\footnotetext{
${ }^{320}$ National Association of State Procurement Officials, 'States with Green Purchasing Profiles' $<$ http://www.naspo.org/dnn/greenmap/California.aspx> accessed 29 Jul 2019.

321 ibid.
} 
more sustainable agriculture. While a significant portion of a state's budget is spent on food procurement (for schools, prisons, etc.), most is currently not spent within the local state economy. While about $10 \%$ of all food purchases within states are acquired by public funds, nationally, less than $3 \%$ of purchasing is directed to local food. ${ }^{322}$

The premise behind using institutional purchasing power to foster local food economies relies upon two propositions. First, if states can use public funds that normally go towards industrial food purchases to instead buy local food, then the government can be both fulfilling its duty to provide food, as well as stimulating the local economy. The State of Michigan, for example, spends about $\$ 300$ million on food procurement for all its school food and Department of Corrections services. By shifting a small percentage of these funds to more local or regional producers and processing facilities, the state could infuse significant funds back into the local economy. Second, an important role of institutional local purchase policies is to serve as a "market primer." ${ }^{223}$ That is, if the public sector provides a steady source of demand for local food, it may allow local producers to scale up and expand into other markets.

Changes in the public procurement of food may not only influence local economies, but there is a growing awareness of a potential link between local food, the environment, and sustainability. This does however raise the issue of whether there is an actual link between buying local and buying green, in both the food context and beyond. Certainly, the environmental externalities of transportation may be lowered due to shorter distances in purchasing local products, but this is only one component of a product's life cycle. In the food context, what you eat is much more of a factor rather than where it is produced, especially considering the high carbon footprint of ruminant meats. ${ }^{324}$

Thus, food miles' advocates are, for the most part, mistaken in their conclusion that reducing the shipment distance of food products will always reduce GHG emissions. In most cases where a local food policy does reduce GHG emissions, this arises due to differences in the emissions intensity of production, not reductions in transport related emissions. ${ }^{325}$ Those interested

\footnotetext{
322 Oran B Hesterman, Fair Food (PublicAffairs 2011) 191.

${ }^{323}$ See ibid 191; Denning (n 223) 40.

${ }^{324}$ Renee Cho, 'How Green is Local Food?' (Earth Institute, Columbia University, 4 Sept 2012) $<$ http://blogs.ei.columbia.edu/2012/09/04/how-green-is-local-food/>.

${ }^{325}$ Misak Avetisyan, Thomas Hertel and Gregory Sampson, 'Is Local Food More Environmentally Friendly? The GHG Emissions Impacts of Consuming Imported versus Domestically Produced Food" (Environmental Resource Economics, Jul 2013) <http://web.ics.purdue.edu/ hertel/data/uploads/publications/avetisyan-hertel-sampson-food-miles.pdf $>$.
} 
in food miles policies may be well-advised to shift their attention to an analysis of the technologies used to produce food across the globe. ${ }^{326}$ This conclusion translates well to other market sectors of durable and consumable goods. How something is made likely has a larger environmental footprint than its distribution channels.

Regardless of their ultimate efficacy, state grown and local food preference laws have grown more popular, and legal challenges to them are likely to be unsuccessful. Writes Ackerman:

It is unlikely that a Dormant Commerce Clause challenge will be successful to a state grown preference law. A state law requiring state agencies to apply a preference when purchasing state-grown goods is classic market participant activity. The majority of federal courts that have considered the issue have also found a state law imposing the same requirement on its political subdivisions to fall within the market participant exception. Similarly, a local entity that is empowered to set the parameters for its market purchases is exercising market participant power when imposing preferences on its purchases. Accordingly, local food purchasing preferences are not likely to violate the Dormant Commerce Clause. ${ }^{327}$

These laws illustrate the power of the market participant exception. States and localities using the market participant exception to prefer local goods have enacted legislation that mandates the purchase of local food. For example:

- Illinois' Local Food, Farms and Jobs Act declares that 20\% of all food and food products purchased by State agencies and State-owned facilities, including, without limitation, facilities for persons with mental health and developmental disabilities, correctional facilities, and public universities, shall, by 2020 , be local farm or food products. ${ }^{328}$

- A San Francisco executive order contains the following imposing directive: "Beginning immediately, all city departments and agencies purchasing food for events or meetings using city funds will utilize guidelines for 'healthy meetings' and purchase healthy, locally produced and/or sustainably certified foods to the maximum extent possible." 329

\footnotetext{
326 ibid.

${ }^{327}$ Ackerman (n 223) 1022

${ }^{328}$ Local Foods, Farms, and Jobs Act, 30 Ill Comp. Stat. 595/10 (2009).

329 Office of the Mayor, City and County of San Francisco, Executive Directive 09-03 (Jul 9, 2009), Healthy and Sustainable Foods for San Francisco, http://civileats.com/wp-content/uploads/2009/07/Mayor-Newsom-Executive-Directive-on-Healthy-Sustainable-Food.pdf.
} 
- A policy in Woodbury County, Iowa mandates that the county "shall purchase, by or through its food service contractor, locally produced organic food" for service in the Woodbury County jail, work release center, and juvenile detention facilities. ${ }^{330}$ The Local Food Purchase Policy's preamble states that it is intended to "increase regional per capita income, provide incentives for job creation, attract economic investment, and promote the health and safety of its citizens and communities." 331

Other states have simply passed legislation that encourages (as opposed to mandates) government entities to purchase local food. Again, this provides a model for states encouraging environmental criteria in purchasing any goods. For example:

- The state of Oregon passed a law allowing contracting agencies using public funds to procure goods for public use to give preference towards an agricultural product that is produced and transported entirely within the state if the product costs not more than $10 \%$ more than a similar product grown out of the state. ${ }^{332}$ Previously, schools, prisons, and other government agencies had to choose the lowest bidder and were not allowed to consider the economic benefits of buying locally. ${ }^{333}$

- In Alabama, the awarding authority may give preference, "provided there is no sacrifice or loss in price or quality, to commodities produced in Alabama or sold by Alabama persons, firms, or corporations." 334

\footnotetext{
330 Woodbury County, Iowa, Policy for Rural Economic Revitalization: Local Food Policy (2006) <http://www.iatp.org/files/258_2_96615.pdf>.

331 ibid.

${ }^{332}$ HB 2763, 75th Legis Assem Reg Sess (Or 2009). However, federal law can preempt this flexibility. For example, the application of such state law to the Federal Child Nutrition Programs (including the National School Lunch Program) is an entirely different matter. Because the National School Lunch Act grants the authority of whether or not to apply a geographic preference when conducting procurements for school food directly to the purchasing institution, states cannot mandate through law or policy that SFAs apply the State's adopted geographic preference regulation. US Department of Agriculture, 'Procurement Geographic Preference Q\&As - Part II, no. 12' (2011) <http://www.fns.usda.gov/cnd/Governance/PolicyMemos/2011/SP18-2011_os.pdf $>$. Thus, no state geographic preference regulation can ever be applied to procurements made under the NSLA.
}

${ }^{333}$ HB 2763 (n 332).

${ }^{334}$ Ala Code $\S 41-16-57$ (1975). 
- In Colorado, food authorities can award contracts for agricultural products to in-state bidders if their produce from the state is of equal quality, suitable for bidding, and sufficient in quantity, and if the bid price is equal to or does not reasonably exceed that of the lowest outof-state bidder. ${ }^{335}$

- In Hawaii, a gradation of set preferences between three and ten percent is applied in favor of "Hawaii products" if they meet certain minimum requirements. ${ }^{336}$

- In Louisiana, products "assembled," "manufactured," or "processed" in Louisiana enjoy a set percentage preference over non-Louisiana products. ${ }^{337}$

- Montana allows public institutions more flexibility to buy Montanaproduced food by providing an "optional exemption in the Montana Procurement Act." 338 The optional exemption allows food procurement officers to directly purchase higher priced Montana-produced food products when, in their discretion, the higher bid is "reasonable and capable of being paid out of that governmental body's existing budget. ${ }^{339}$

If states can engage in sheer economic protectionism using the market participant exception, they can certainly make environmental requirements in procurement decisions. However, lawmakers must ensure that any potential legislation falls within the market participant exception. ${ }^{340}$

From a policy standpoint, states must consider where their interests would be most greatly met. In other words, where should the public purchasing

${ }^{335}$ Colo Rev Stat $\S 8-18-103$ (2003).

${ }^{336}$ Haw Rev Stat § 103D-1002(a) (2006).

${ }^{337}$ La Rev Stat $§ 38: 2251$ (2005).

${ }^{338}$ Derick Braaten and Marne Coit, 'Legal Issues in Local Food Systems' (2010) 15 Drake J Agriculture L 9, 10.

339 ibid.

${ }^{340}$ A common example of a state acting outside of its market participant exception allowance is if a state tries to shape the market through its tax structure. See, e.g., Metropolitan Life Insurance Co v Ward 470 US 869, 879 (1985) (declaring Alabama's implementation of a tax to increase state economy unconstitutional); Denning (n 223) 145 (discussing how Iowa's Local Farmer and Food Security Act of 2010 that offers a 20 percent tax credit to grocers against the cost of purchasing "Local Farm Products" does not fall under protection of market participant exception). Another example is if a state uses its market power in one market to regulate behavior of private individuals outside of that market. See South-Central Timber Development Inc (n 289) 82. 
power be focused-K-12 schools, universities, hospitals, or correctional facilities? In the U.S., according to 2004 figures, K-12 schools rank first as the nation's largest institutional purchaser. ${ }^{341}$ State colleges and universities are the second-largest institutional purchasers in the U.S. ${ }^{342}$ The health care sector is the third largest institutional purchaser in the nation. ${ }^{343}$ Any such analysis would be prudent to perform, regardless of the locale, in the U.S. or Europe, and in other market sectors beyond the food procurement context including environmental preferences on any durable or consumable goods. In Part 6.6, the use of green public procurement provisions by American states are discussed in greater detail.

\subsection{Generally Applicable Environmental Standards and Regulation}

American states, as market participants, can lawfully support state and local economies. In Smith Setzer \& Sons, Inc. v. S.C. Procurement Review Panel, the U.S. Court of Appeals for the Fourth Circuit upheld the State of South Carolina's local preference law, requiring governmental agencies to purchase products made, manufactured, or grown in South Carolina, on the grounds that it was not a violation of the dormant commerce clause because the state was acting in the marketplace to purchase for its own consumption as a market participant, not a market regulator. ${ }^{344}$ But what if the rationale is the environment or public health?

For virtually any public procurement decision, including environmental standards, the dormant commerce clause analysis does not apply due to the market participant exception, and the decision will be upheld. But what if the state is acting as a regulator to promote state interests in environmental protection and sustainability? Could American states create these sorts of environmental conditions? Or would this violate the commerce clause?

Even-handed and non-discriminatory, in its intent or application, environmental regulation is the norm and will likely be upheld. Nevertheless, there is a real risk that a state may pass legislation without adequately considering its impact elsewhere in the country. In addition, there is also the risk that a state will use what appears to be non-discriminatory legislation as a covert means

${ }^{341}$ Moira Beery and Mark Vallianatos, Center for Food Justice and Urban and Environmental Policy Institute, Farm to Hospital: Promoting Health and Supporting Local Agriculture (2004) 3.

342 ibid.

343 ibid.

${ }^{344}$ Smith Setzer \& Sons, Inc v South Carolina Procurement Review Panel 20 F 3d 1311 (4th Cir 1994). 
of burdening out-of-state businesses. Thus, some degree of judicial scrutiny seems warranted. ${ }^{345}$

In order to guard against these risks, the U.S. Supreme Court subjects nondiscriminatory state legislation to a balancing test known as the Pike test. In Pike v. Bruce Church, Inc., ${ }^{346}$ the Court stated that, in evaluating such regulation, the impact of a statute on interstate commerce is balanced against the state's justifications for the statute. Where a statute regulates even-handedly in an effort to promote a legitimate local public interest, and its effects on interstate commerce are only incidental, the law will be upheld unless the burden imposed on such commerce is clearly excessive in relation to the anticipated local benefits. ${ }^{347}$

Environmental laws have fared well under this commerce clause doctrine test. ${ }^{348}$ For example, in Minnesota v. Clover Leaf Creamery Co., the U.S. Supreme Court upheld a state law prohibiting the use of non-recyclable plastic containers for milk. ${ }^{349}$ The Court said that the environmental benefits of the law outweighed any harms to interstate commerce. ${ }^{350}$ In Maine v. Taylor, the Supreme Court upheld a state ban on the importation of out-of-state baitfish under the theory that the state has a "legitimate interest in guarding against imperfectly understood environmental risks, despite the possibility that they may ultimately prove to be negligible." ${ }^{\prime 351}$ The state of Maine was concerned that fishing bait travelling across state boundaries would have an adverse ecological impacts on Maine's freshwater lakes and streams by introducing invasive species. ${ }^{352}$ This reasoning prevailed.

\footnotetext{
${ }^{345}$ Daniel Farber, 'Legal Guidelines for Cooperation Between the EU and American State Governments' in David Vogel and Johan FM Swinnen (eds) Transatlantic Regulatory Cooperation: The Shifting Roles of the EU, the U.S. and California (2011) 3, 7-8.

${ }^{346}$ Pike (n 252) 137.

347 ibid 142.

${ }^{348}$ Farber (n 345) 12.

${ }^{349}$ Clover Leaf Creamery Co (n 226) 461.

350 ibid 473 ("Even granting that the out-of-state plastics industry is burdened relatively more heavily..., we find that this burden is not 'clearly excessive' in light of the substantial state interest in promoting conservation of energy and other natural resources ....").

${ }^{351}$ Maine (n 271) 148.

352 ibid.
} 


\subsection{Preemption Doctrine: An Additional Factor When States Regulate}

In addition to possible violation of the dormant commerce clause, states that set higher environmental standards for products or processes must also be concerned with "preemption" by federal law. Article VI of the U.S. Constitution declares:

This Constitution, and the Laws of the United States which shall be made in Pursuance thereof. . . shall be the supreme Law of the Land. ${ }^{353}$

Accordingly, when a state law "interferes with or is contrary to federal law," the state law is "preempted" and a court may invalidate it. ${ }^{354}$ Chief Justice John Marshall of the U.S. Supreme Court had already held in 1824 that when a state law conflicts with federal law, "the law of State ... must yield to it."355

In practice, courts hold that state or local environmental laws are preempted when there is either express or implied preemption. ${ }^{356}$ "Pre-emption may be either expressed or implied, and 'is compelled whether Congress' command is explicitly stated in the statute's language or implicitly contained in its structure and purpose. ${ }^{357}$ Express preemption occurs when a federal law explicitly prohibits state and local governments from legislating or regulating. ${ }^{358}$ For instance, the Comprehensive Environmental Response, Compensation, and Liability Act of 1980 (CERCLA) contains an express preemption clause, stating that " $[\mathrm{n}]$ o Federal, State, or local permit shall be required for the portion of any removal or remedial action conducted entirely onsite, where such remedial action is selected and carried out in compliance with this section." 359

Even when a statute includes no express provision for preemption, a court may hold that the state or local law is impliedly preempted. Preemption, in the case of state and local environmental laws, can be implied under two theories:

\footnotetext{
${ }^{353}$ US Const art VI.

${ }^{354}$ Chemerinsky (n 248) 392 (citing Gade v National Solid Waste Management Association, 505 US 88, 108 (1992)).

355 ibid 392 (citing Gibbons v Ogden 22 US 1 (1824)).

${ }^{356}$ Paul S Weiland, Comment, 'Federal and State Preemption of Environmental Law: A Critical Analysis' (2000) 24 Harvard Environmental L Rev 237, 238.

${ }^{357}$ Gade (n 354) 98 (citing Jones v Rath Packing Co 430 US 519, 525 (1977); Shaw v Delta Air Lines, Inc 463 US 85, 95 (1983); Fidelity Federal Savings \& Loan Association v De la Cuesta 458 US 141, 152-53 (1982)); See Chemerinsky (n 248) 394-95.

${ }^{358}$ See Weiland (n 356) 253; Chemerinsky (n 248) 396-97.

35942 USC § 9621(e)(1) (2006). However, even when Congress has included an express preemption clause, "it rarely provides guidance as to the scope of preemption." Chemerinsky (n 248) 397.
} 
"field preemption" and "conflict preemption." 360 Field preemption occurs "where the scheme of federal regulation is "so pervasive as to make reasonable the inference that Congress left no room for the States to supplement it." Conflict preemption, on the other hand, is found "where "compliance with both federal and state regulations is a physical impossibility,' or where state law 'stands as an obstacle to the accomplishment and execution of the full purposes and objectives of Congress." "362

A court may evoke "field preemption" when "[t]he scheme of federal regulation [is] so pervasive as to make reasonable the inference that Congress left no room for the States to supplement it [or] the federal interest is so dominant that the federal system will be assumed to preclude enforcement of state laws on the same subject. ${ }^{363}$ The Supreme Court has held that not only statutes, but also extensive federal regulations in a given field, may preempt the enforcement of state and local laws. ${ }^{364}$ Courts will consider several factors when determining whether Congress intended the federal laws to occupy the field, including whether the field has traditionally been regulated by the federal government, whether it has traditionally been a state or local interest, whether Congress expressed the intent (in the legislative history) that the law exclusively occupy the field, and whether the state/local laws could impede the federal regulations. ${ }^{365}$

"Conflict preemption" applies when it is impossible to comply with both federal and state law, ${ }^{366}$ or when a state law sets a higher standard than a federal law that a court sees as an exclusive standard. ${ }^{367}$ In Florida Lime \& Avocado Growers, the Supreme Court determined that the federal standard for saleable avocados was a minimum, rather than exclusive, standard, and that a state could therefore enforce stricter standards without being preempted by the federal law. ${ }^{368}$

\footnotetext{
${ }^{360}$ See Weiland (n 356) 253; Chemerinsky (n 248) 394-95.

${ }^{361}$ Gade (n 354) 98 (quoting Fidelity Federal Savings \& Loan Association (n 357) 153).

362 ibid 98 (citing Florida Lime \& Avocado Growers, Inc v Paul 373 US 132, 142-43 (1963); Hines v Davidowitz 312 US 52, 67 (1941); Felder v Casey 487 US 131, 138 (1988); Perez v Campbell, 402 US 637, 649 (1971)). Chemerinsky identifies an additional variety of implied preemption, where the state law blocks the achievement of the "full purposes and objectives of Congress." Chemerinsky (n 248) 395 (quoting Hines (n 362) 67). Additionally, states and local governments are preempted when they attempt to tax or regulate the federal government. See generally ibid 416-19.

${ }^{363}$ Rice v Santa Fe Elevator Corp 331 US 218, 230 (1947).

${ }^{364}$ See Chemerinsky (n 248) 406 (citing ibid 218).

365 ibid 408.

${ }^{366}$ Gade (n 354) 98 (citing Florida Lime \& Avocado Growers, Inc (n 362) 142-43).

367 Chemerinsky (n 248) 410.

368 ibid 410 (citing Florida Lime \& Avocado Growers, Inc (n 362) 146).
} 
California's Safe Drinking Water and Toxic Enforcement Act of $1986,{ }^{369}$ also known as "Proposition 65," illuminates the preemption doctrine. It has been repeatedly challenged on the basis of preemption-mostly unsuccessfully-for several decades. Proposition 65 does not restrict the quantity of hazardous substances in consumer products, but rather, it requires warning labels that are triggered by quantities that are "orders of magnitude" lower than the federal limits of the listed chemicals. ${ }^{370}$ Since federal law regulates the chemicals and also sets standards for any number of products that may contain the chemicals, Proposition 65 would seem to be susceptible to preemption challenges.

Proposition 65 has proven to robustly resist preemption by federal law. Courts have held that the application of Proposition 65 does not contradict or interfere with federal interests as represented by the Federal Hazardous Substances Act, ${ }^{371}$ the U.S. Food \& Drug Administration regulations under the Medical Devices Act, ${ }^{372}$ and the Federal Insecticide, Fungicide, and Rodenticide Act, ${ }^{373}$ to name just a few examples. Still, in some cases, where a federal law provided for express preemption ${ }^{374}$ or when the California warning label conflicted with federal policy, ${ }^{375}$ courts have ruled the specific application of Proposition 65 to be preempted by federal law.

\subsection{Green Public Procurement by the U.S. Federal Government}

With an environmental footprint arising from its 360,000 buildings, 650,000 fleet vehicles, and $\$ 400$ billion products and services output, the United States federal government is under scrutiny from environmentalists, legal authorities, and politicians alike who are not only encouraging, but compelling, federal agency procurement officers to prioritize green procurement when pursuing goods and services. ${ }^{376}$ "Since 1993, the U.S. government has accelerated

${ }^{369}$ Cal Health \& Safety Code $\S \S 25249.5-25249.13$ (2019).

370 Trenton H Norris, 'Consumer Litigation and FDA-Regulated Products: The Unique State of California' (2006) 61 Food and Drug LJ 547, 549.

${ }^{371}$ People ex rel Lungren v Cotter \& Co 62 Cal Rptr 2d 368, 381 (Cal Ct App 1997).

372 Committee of Dental Amalgam Manufacturers \& Distributors v Stratton 92 F 3d 807 (9th Cir 1996).

${ }^{373}$ Chemical Specialties Manufacturers Association Inc v Allenby 958 F 2d 941 (9th Cir 1992).

374 American Meat Institute v Leeman 102 California Reporter 3d 759 (Cal Ct App 2009)

375 Dowhal v SmithKline Beecham Consumer Healthcare 88 P 3d 1, 15 (Cal 2004).

${ }^{376}$ Resolve, Pilot Testing EPA Guidelines for Environmental Performance Standards and Ecolabels $<$ www.resolv.org/site-guidelines/background-information-and-resources/> accessed 29 Jul 2019. 
the process of leveraging its purchasing power by setting more stringent, mandatory, environmental performance standards in the procurement context ... ,377

While American states have recently been the biggest innovators in green public procurement (see Parts 6.3 and 6.7), it was federal discourse on green procurement that encouraged state and local governments to adopt these protocols. The sequence of procurement efforts supports the idea that the evolution of the green procurement in state and local governments, which mimics federal legislation's lexicon, derived from and was spurred by federal initiatives.

The federal government's initiatives to implement green procurement spurred local and state government action, a goal of the U.S. Environmental Protection Agency (EPA). Federal policies and practices relating to green procurement may have significant impact on the adoption of GPP practices by state and local governments, as well as the private sector. ${ }^{378}$ Federal influence on promoting local sustainable procurement efforts is further evidenced by the lexicon used by state and local governments which mirrors that of federal efforts.

The green purchasing movement began to blossom when, in late 1993, President Clinton issued Executive Order 12873 which required consideration of "environmentally preferred products" in federal government purchasing. He later signed two more Executive Orders that further galvanized green procurement initiatives in the federal government. ${ }^{379}$ These orders spurred changes in the way federal government approached and their procurement practices. ${ }^{380}$ Municipalities and state governments followed suit and experimented with their own versions of environmentally friendly procurement programs. ${ }^{381}$

\footnotetext{
${ }^{377}$ Light, 'Public and Private Procurement in Environmental Governance' (n 2) (citing US Environmental Protection Agency, 'Environmentally Preferable Purchasing Program History' $<$ https://www.epa.gov/greenerproducts/environmentally-preferable-purchasing-program-history $>$ ).

${ }^{378}$ Eric A Fischer, 'Green Procurement: Overview and Issues for Congress' (Congressional Research Service, 20 Apr 2010) <https:/www.epa.gov/sites/production/files/2015-09/documents/green_procurement_-_overview_and_issues_for_congress.pdf $>$.

${ }^{379}$ Exec Order No 13,101, Greening the Government Through Waste Prevention, Recycling, and Federal Acquisition, 63 Fed Reg 49,643 (Sept 9, 1998); Exec Order No 13,148, Greening the Government through Government Leadership in Environmental Management (Apr 21, 2000).

380 Oki Radich, 'Green Procurement Hits the Internet' (Dec 2011) $<$ https://www.ncmahq.org/docs/default-source/default-document-library/articles/cm1211--$52-59>$.

381 ibid.
} 
EPA conducted its first comprehensive report on green procurement in 1996, including feedback and information from the few state and local governments who had green procurement policies already established. One of the earliest local governments with an environmentally-focused procurement policy was Kings County, Washington. When asked what weaknesses were found in the current framework of green procurement, Washington officials said that local governments were still waiting for leadership from the federal government. They specifically said that the term "environmental preferable products" (from Clinton's then recent executive order) needed to be better defined by federal action in order to create uniformity and guidance for state and local governments. 382

A 2015 EPA report aimed to quantify and qualify green procurement actions at the state and local level. In the report, EPA looked at how many of the state and local governments used an Environmentally Preferred Product (EPP) definition in their green procurement policy. Many state and local governments, such as Cincinnati, Ohio; Jackson County and Kansas City, Missouri; King County and Seattle, Washington; and Washoe County, Nevada, use language near identical to the federal Executive Orders in order to define EPP in their executive orders, statutes, and written policies ${ }^{383}$ Others provide slightly different, but very similar definitions. ${ }^{384}$ Over 25 states and 30 local governments were used in the report to reference their policies surrounding "environmentally preferred products." ${ }^{385}$

More recently on the federal level, President Obama endeavored to imprint sustainability at a federal level by issuing several Executive Orders (EOs) that expressly and peripherally relate to an agenda to transform the U.S. into a leading sustainable nation by formally calling for green public procurement (GPP) among federal agencies. ${ }^{386}$ Obama's EO 13693, "Planning for Sustainability in the Next Decade," was signed on March 19, 2015. ${ }^{387}$

\footnotetext{
382 US Environmental Protection Agency, A Study of State and Local Government Procurement Practices that Consider Environmental Performance of Goods and Services (1996).

${ }^{383}$ US Environmental Protection Agency, State and Local Government Pioneers: How State and Local Governments are Implementing Environmentally Preferable Purchasing Practices (2015) <https://www.epa.gov/sites/production/files/2015-05/documents/statenlocal.pdf> .

384 ibid.

385 ibid.

${ }^{386}$ Exec Order No 13,423, Strengthening Federal Environmental, Energy, and Transportation Management, 72 Fed Reg 3,919 (Jan 26, 2007); Exec Order No 13,514, Federal Leadership in Environmental, Energy, and Economic Performance, 74 Fed Reg 194 (Oct 8, 2009).

${ }^{387}$ Exec Order No 13,693, Planning for Federal Sustainability in the Next Decade, 80 Fed Reg 15,871 (Mar 25, 2015); US Army Corps of Engineers, Federal Facilities Environmental Stewardship and Compliance Assistance Center <https://www.fedcenter.gov/programs/buygreen $>$ updated 29 May 2019.
} 
The explicit goal of EO 13693 is "to maintain Federal leadership in sustainability and greenhouse gas emission reduction ... where life-cycle costeffective." ${ }^{388}$ In section 3(i) of the 2015 EO, Obama echoes the plea of its predecessors EO $13514^{389}$ and EO 13101, ${ }^{390}$ renewing the need for federal agencies to promote sustainable acquisition by ensuring factors are not only considered, but incorporated "to the maximum extent practicable" for all appropriate procurements within the scope of the planning, award, and execution of the agency's acquisition. ${ }^{391}$ The factors EO 13963 emphasizes are: (1) purchasing preferences for recycled content products; (2) energy and water efficient products and services; (3) bio-based designated products, sustainable services and products; and (4) environmentally preferable products that exceed EPA recommended labels. ${ }^{392}$

Outwardly, Obama's mandate seems merely to have accomplished establishing good faith agency shopping, cloaked as purchasing preferences; though perhaps this leads to increased agency discussion and cooperation. U.S. agency GPP programs are still in their infancy, though progress is being made.

The agency's thinking about sustainable purchasing is evolving, with a focus on life-cycle approaches, return on investment, risk mitigation, intentionality, and partnership, [Stephen Leeds, Office of the Administrator at the General Services Administration,] said. GSA is adopting a life-cycle approach to sustainable purchasing as it 'bridges the silos of disposal and acquisition,' $\mathrm{Mr}$. Leeds explained. The agency is sending a clear signal to the private sector that

\footnotetext{
${ }^{388}$ Exec Order No 13,693, Planning for Federal Sustainability in the Next Decade, 80 Fed Reg 15,871, 15,871 (Mar 25, 2015).

${ }^{389}$ It must be noted that that the General Services Administration (GSA) has played a key role, in relation to EO 13514, in furthering sustainable procurement practices throughout the federal government as it is responsible for formulating and maintaining government-wide policies covering a variety of administrative actions, including those related to procurement and management. National Research Council, Sustainability Considerations for Procurement Tools and Capabilities: Summary of a Workshop (2012) 1-2.
}

${ }^{390}$ McCrudden (n 78) 390-91 ("In 1998, President Clinton issued an executive order encouraging federal agencies to buy environmentally preferable products."). See also National Research Council (n 389) 1 ("In particular, two Executive Orders-EO 13423, Strengthening Federal Environmental, Energy, and Transportation Management, signed in 2007; and EO 13514, Federal Leadership in Environmental, Energy, and Economic Performance, signed in 2009-include specific goals and objectives for sustainable purchasing by agencies. Federal government green purchasing efforts, however, can be traced back to at least EO 12759 signed by President Bush in 1991.").

${ }^{391}$ Exec Order No 13,693, Planning for Federal Sustainability in the Next Decade, 80 Fed Reg 15,871, 15,875 (Mar 25, 2015); US Army Corps of Engineers, 'Federal Facilities Environmental Stewardship and Compliance Assistance Center' <https://www.fedcenter.gov/programs/buygreen $>$ updated 29 May 2019.

392 Exec Order No 13,693, Planning for Federal Sustainability in the Next Decade, 80 Fed Reg 15,871, 15,875 (Mar 25, 2015). 
the focus is broader than the individual environmental impacts of purchasing decisions. 393

However, embodying the starkest difference between the EU and U.S. and "[n]otwithstanding its commitment to competition in contracting, the U.S. procurement system remains fundamentally premised upon a preference for the purchases of domestic rather than non-domestic goods" (e.g., Fly America Act). ${ }^{394}$

The Trump Presidential Administration has closely scrutinized regulatory changes, as evidenced by a memorandum for the Heads of Executive Branch Departments and Agencies to halt publication of any new rules until designated presidential appointees review and approve them. ${ }^{395}$ On May 17, 2018, President Trump issued EO 13834 which directs Federal agencies to manage their buildings, vehicles, and overall operations to optimize energy and environmental performance, reduce waste, and cut costs. Trump's EO 13834 officially revokes Obama's EO 13693. ${ }^{396}$

Nevertheless, there are various influential collateral laws, regulations, and agreements that embody the ambition of the Obama EO. For example, the Comprehensive Procurement Guideline (CPG) program, as part of EPA's ongoing initiative to promote the repurposing of solid waste residual materials, established a list of 61 recycled-content products to be re-used in the manufacture of new products. ${ }^{397}$ Once a product is designated as made with recovered materials, the EPA requires federal agencies to purchase such materials following their suggested purchase practice. ${ }^{398}$

The Federal Acquisitions Regulations (FAR), ${ }^{399}$ in response to the direct initiatives of EO 13693 and implementing executive branch policy, dictate

\footnotetext{
${ }^{393}$ National Research Council (n 389) 6.

${ }^{394}$ Organisation for Economic Cooperation and Development, The Environmental Performance of Public Procurement: Issues of Policy Coherence (2003) 202; Conway (n 195) 45 (Public procurement goals in U.S. include: "Protection of domestic industry from foreign competition (Buy American Act legislation); Ensuring opportunities for small businesses; Ensuring that workers are paid according to prevailing wage rates and have adequate working conditions; and ... [P]romoting environmental and sustainable objectives.").

${ }^{395}$ Daniel E Johnson and Ryan Burnette, 'New Policies on Sustainable Acquisition: Among Last Proposed FAR Rules of Obama Administration' (The National Review 7 Feb 2017) $<$ http://www.natlawreview.com/article/new-policies-sustainable-acquisition-among-last-proposed-far-rules-obama $>$.
}

${ }^{396}$ Exec Order No 13,834, Efficient Federal Operations, 83 Fed Reg 23,771 (May 17, 2018).

${ }^{397}$ Exec Order No 13,423, Strengthening Federal Environmental, Energy, and Transportation Management, 72 Fed Reg 3,919 (Jan 26, 2007).

398 ibid.

399 Steven W Feldman and W Noel Keyes, Government Contracts in a Nutshell 3 (5th edn, West Academic Publishing 2011) 3 ("Effective April 1, 1984, the Federal Acquisition Regula- 
acquisition policies and procedures to presently safeguard and proactively promote the quality of the global environment by fostering markets for sustainable technologies, materials, products and services ${ }^{400}$ Specifically, federal agencies must facilitate sustainable acquisition by ensuring that $95 \%$ of new contract actions for the supply of products and for the acquisition of services (including construction) require that the products are: (1) energy efficient; (2) water-efficient; (3) bio-based; (4) environmentally preferable; (5) non-ozone depleting; and (6) made with recovered materials. ${ }^{401}$ For bio-based products, and those made with recovered materials, purchase procedures apply to all agency acquisitions of EPA and United States Department of Agriculture (USDA) designated items if the price of the item exceeds $\$ 10,000 .{ }^{402}$ Once the EPA or USDA designates an item for green procurement, agencies have one year to reexamine and amend their procurement programs, and are exempt from procurement only if the item cannot be acquired within a reasonable time period at a reasonable cost, or cannot meet reasonable performance standards. ${ }^{403}$

In a robust effort to facilitate federal purchasers in selecting products that meet sustainable procurement goals, the EPA proposed Draft Guidelines for Product Environmental Performance Standards and Ecolabels for Voluntary Use in Federal Procurement. ${ }^{404}$ The EPA contracted with Resolve Inc. to assemble a diverse Governance Committee to construct and carry out a 2015 pilot test for three product categories: building paints/coatings/removers,

tion (FAR) was established for the codification and publication of uniform policies and procedures for acquisition by all executive agencies, unless excluded. The System consists of the FAR (which is called "the primary document") and agency acquisition regulations that implement or supplement the FAR. FAR clauses and provisions are incorporated in covered federal solicitations and contracts either in full text (where there is a fill-in) or more commonly by reference. Clauses and provisions included by reference have the same force and effect as those FAR terms included in full text. The FAR is available at https://www.acquisition.gov/Far/."). See also ibid at 179, 359 (noting that FAR contains increased emphasis on environmental and conservation concerns, and agencies shall consider energy efficiency and acquire items composed of highest percentage of recovered materials practicable, and includes provisions prescribing acquisition policies and procedures supporting the government's program for protecting and improving the quality of the environment through pollution control, energy conservation, identification of hazardous material, and use of recovered materials).

${ }^{400}$ FAR $\S 23.400$ (Nov 12, 2015).

${ }^{401}$ FAR $§ 23.103-104$ (Nov 12, 2015). See also Nash (n 35) 492.

${ }^{402}$ FAR $§ 23.400$ (Nov 12, 2015).

${ }^{403}$ FAR $§ 23.404$ (b) (Nov 12, 2015).

${ }^{404}$ US Environmental Protection Agency, 'Draft Guidelines for Product Environmental Performance Standards \& Ecolabels for Use in Federal Procurement' (Dec 2014) $<\mathrm{http}$ //www2.epa.gov/sites/production/files/2015-09/documents/draftguidelines_i_-_iii__iv_-_nov2013_and_revised_ii_-_dec2014.pdf>. 
building floors, and furniture. ${ }^{405}$ The express purpose of the pilot test was to generate a "transparent, fair, and consistent" set of criteria to help purchasers in recognizing federal green standards and eco-labeling for energy and water efficiency, and safer chemicals when buying products. ${ }^{406}$

Through this process, EPA developed "Recommendations of Specifications, Standards, and Ecolabels for Federal Purchasing," a list of eco-labels that "intended to help federal purchasers identify and procure environmentally sustainable products and services." 407 Transcending extant EPA eco-labels was one of the Obama EPA's candid objectives. The Safer Choice labeling system, for example, is a voluntary opportunity for chemical product manufacturers to acquire retail recognition for their initiative in chemical safety. ${ }^{408}$ Thus, one of the pilot test's primary objectives was to promote deliberate assimilation and discernment among existing green procurement standards and coordinating eco-labels; "for example distinguishing between baseline and higher performing criteria, and considering how to address purchase categories that have both single-attribute or life-cycle stage standards as well as multi-attribute, multi-life-cycle stage standards." ${ }^{409}$ In April 2016, as a result of the pilot testing, EPA's Environmentally Preferable Purchasing Program released its criteria for assessing standards and eco-labels. ${ }^{410}$

${ }^{405}$ US Environmental Protection Agency, 'Draft Guidelines: Product Environmental Performance Standards and Ecolabels for Voluntary Use in Federal Procurement' (Nov 2013) $<$ https://www.regulations.gov/document?D=EPA-HQ-OPPT-2013-0579-0001>.

${ }^{406}$ Because the marketplace is flooded with non-federal standards and eco-labels that imply certification of environmental and human health benefits, the EPA guidelines attempt to recognize non-governmental standards and eco-labels, those beyond Energy Star, WaterSense, and Safer Choice for use in achieving/accomplishing agency green procurement. US Environmental Protection Agency, 'Guidelines for the Assessment of Environmental Performance Standards and Ecolabels for Federal Procurement' <http://www2.epa.gov/greenerproducts/draftguidelines-product-environmental-performance-standards-and-ecolabels-voluntary $>$ accessed 18 Apr 2018; Resolve, Pilot Testing EPA Guidelines for Environmental Performance Standards and Ecolabels $<$ www.resolv.org/site-guidelines/background-information-and-resources/> accessed 29 Jul 2019.

${ }^{407}$ US Environmental Protection Agency, 'Recommendations of Specifications, Standards, and Ecolabels for Federal Purchasing' $<$ https://www.epa.gov/greenerproducts/epas-recommendations-specifications-standards-and-ecolabels-federal-purchasing> accessed 18 Apr 2018.

408 Jennifer McPartland, 'EPA rolls out its redesigned labels under the newly minted Safer Choice Program' (Environmental Defense Fund 4 Mar 2015) $<$ http://blogs.edf.org/health/2015/03/04/epa-rolls-out-its-redesigned-labels-under-the-newlyminted-safer-choice-program/>

${ }^{409}$ Resolve, Pilot Testing EPA Guidelines for Environmental Performance Standards and Ecolabels $<$ www.resolv.org/site-guidelines/background-information-and-resources/> accessed 29 Jul 2019.

${ }^{410}$ US Environmental Protection Agency, EPA Environmentally Preferable Purchasing Program Pilot to Assess Standards and Ecolabels for EPA's Recommendations to Federal Agencies: Final PILOT Assessment Guidelines (Dec 2016). 
However, the EPA program has not monetized the environmental assessments or engaged in life-cycle costing. LCC methodology, intended to provide an acquisition method that is consistent with the concept of sustainability while simultaneously incurring the lowest cost and acquiring the best value, calculates a savings-to-investment ratio as guidance. ${ }^{411}$ Thus, the EPA to date has the tools (in a few test product areas) to help inform criteria to include in government contracts/tender offers and to evaluate eco-labels (in those product areas), but not to do LCC.

The EPA preferred eco-labels list illustrates the practical and user-friendly preference of government agencies, and smaller municipalities in particular in both the EU and U.S.- simply use a list of highly thought-of private labels and certifications when doing green procurement, rather than engage in LCC. It also explains the EU desire to develop a standardized LCC methodology, though this thesis continues to suggest that an accompanying eco-label will likely be necessary and questions whether this can be fully accomplished absent involvement of industry and third-party certifiers.

\subsection{Green Public Procurement by American States}

\subsubsection{Framework Categories for U.S. Green Public Procurement}

Scholars and policymakers have argued that state and local governments have considerable potential to encourage and drive market innovation. Part 6.3 above briefly described some GPP initiatives in American States in the context of the market participant exception, and explained how public procurement criteria in the U.S. can be based on geography or preferences of local business. This Part 6.7 looks at specifically at GPP provisions at the state and local level. At least thirty American States have some type of green purchasing program. ${ }^{412}$ State and local green public procurement initiatives that seek to promote environmental interests can be placed into three broad categories: (1) general consideration of environmental factors in a product's life cycle and/or environmentally preferable products (EPP) procurement policies, (2) encour-

\footnotetext{
411 Or Admin R 731-147-0020 (2019). Savings-to-investment ratio compares "the present value of net cost savings attributable to an energy conservation measure to the present value of the net increase in investment, maintenance and operating, and replacement costs less salvage value or disposal cost attributable to that measured over a study period." 10 CFR $\S$ 455.64(a)(c)).

${ }^{412}$ National Association of State Procurement Officials (NASPO), 'States with Green Purchasing Programs or Activities' <http://www.naspo.org/GreenMap> accessed 29 Jul 2019.
} 
agement of purchasing energy efficient products, and (3) purchasing of products that are recyclable. New York State's Executive Order 4 (2008) for example, promotes all three categories. ${ }^{413}$

Within these categories, state and local governments in the U.S. promote environmental interests through their procurement policies. In their most subtle form, governments promote procurement of products that are energy efficient or conducive to recyclability without mention of environmental motivations. At a more moderate level of enthusiasm, traditional procurement policies often promote environmental interests by introducing life-cycle analysis and promoting the use of EPPs. The most radical form of sustainable procurement is the development of formal green procurement policies with the express intention of establishing an environmentally sustainable procurement structure for the government, but the LCC methodology to do so is currently lacking.

\subsubsection{Environmentally Preferable Products and Life-Cycle Costing Policies}

State and local governments have adopted policies that seek to comprehensively promote environmentally sustainable procurement methods by either requiring or encouraging government agencies to consider the environmental impact of any materials, goods, or services procured. These policies often begin by stating an intention to mitigate harm to the environment and improve human health. There are two common mechanisms seen in green procurement policies: (1) that the government use environmentally preferable products (EPP) when practicable, and/or (2) that environmental costs in a product's life cycle be considered when purchasing a product, though methodologies remain very ill-defined in how to consider these factors.

Often, both standards are found together in a green procurement policy, with the environmental life-cycle costs of a product often being part of the definition of EPP, as is the case in the State of Delaware. ${ }^{414}$ State or municipal policies may define LCC analysis; for example, "the study of the costs associated with a product through its life cycle - from acquisition to its end-of-life management." ${ }^{15}$ Hartford, Connecticut procurement policy requires that LCC analyses include the "consideration of societal and environmental factors." 416 In the Colorado Code of Regulations, LCC analysis includes an assessment of

\footnotetext{
${ }^{413}$ New York State, Executive Order No 4 (2008), Establishing a State Green Procurement and Agency Sustainability Program, https://www.dec.ny.gov/energy/71389.html.

414 19-4106 Del Code Regs (2018).

415 ibid.

${ }^{416}$ Hartford, Conn Code $§ 2-548$ (2017).
} 
"life-cycle environmental health and energy impacts resulting from new material extraction, transportation, manufacturing, use, and disposal." ${ }^{417}$ In Oregon, the public procurement policy includes a LCC analysis which references any "impacts to the environment or public health." "118

The Town of Indian Head, Maryland, lists a number of factors to consider when engaged in sustainable procurement: pollutant releases, toxicity, waste generation, greenhouse gas emissions, energy consumption, depletion of natural resources, and impacts on biodiversity. ${ }^{419}$ More often, however, green procurement policies do not enumerate a specific list of factors for consideration under a LCC analysis or environmental purchasing preferences. Delaware's green procurement policy, noted earlier, includes more general language: "life-cycle cost analyses should consider products which demonstrate life cycle impact benefits associated with environmentally preferred products when compared to traditional products." ${ }^{420}$

EPP can be defined, here by a town in the State of New York, as "any product that has a lesser impact on human health and the environment when compared with a competing product, in consideration of raw materials acquisition, production, manufacturing, packaging, distribution, reuse, operation, and/or disposal of the product." ${ }^{\prime 21}$ This definition, of course, is remarkably similar to that of any LCC analysis. In this way, purchasing EPPs, using simplified criteria like eco-labels, work as a precursor to more complex LCC methodologies as discussed in Part 9 below.

What standards are used to identify EPPs? Green procurement policies sometimes use recognized labels and environmental standards in making procurement decisions. For instance, Delaware has specified that all appliances and equipment meet or exceed the EPA's Energy Star standards and have the Energy Star label (see further discussion of energy efficiency procurement policies below). ${ }^{422}$ Delaware also states that, when possible, purchased products that use water should meet the U.S. EPA's WaterSense designation standard of efficiency. ${ }^{423}$

Other policies establish a committee consisting of one or two members from various government departments to make recommendations to the director of purchasing for EPPs. These committees often require representative members from recognized environmental or conservation groups (which may

\footnotetext{
${ }^{417}$ Colo Code Regs $\S 101-9$ (2018).

418 Or Admin R 125-247-0170 (2019).

${ }^{419}$ Indian Head, Md, Ordinances No 06-01-17, art III, § 3-22 (2017).

420 19-4106 Del Code Regs (2018).

${ }^{421}$ Brookhaven, NY Code ch 7B: Green Procurements (2009).

422 19-4000-4000 Del Code Regs (2018).

423 ibid.
} 
be fulfilled by representatives from an environmental government department). ${ }^{424}$

\subsubsection{Energy Efficiency}

A number of state and local procurement policies require purchasing of energy efficient products and services, but make no reference to environmental impacts or health. Items within this category are found in traditional and nonenvironmental procurement policies, though energy efficiency is often also used within the definition of a government's LCC analysis method.

For example, in the small city of Sterling, Colorado, the definition of their "lowest bid" includes consideration of life-cycle costs over the "normal lifetime of the product and energy efficiency in consumption of nonrenewable fuels." ${ }^{425}$ The New York City Administrative Code requires that any energy using product purchased or leased by any agency must comply with the Energy Star program and be Energy Star labeled. ${ }^{426}$ The Town of Suwannee, Georgia requires that any vehicle purchased or leased for government use must be the most practical and energy efficient possible pursuant to its purpose. ${ }^{427}$ Energy efficiency is generally regarded as a factor beneficial to environmental health and sustainability, as well as creating long-term cost savings.

\subsubsection{Recycling of Products}

Many local procurement policies demand the use of recyclable products, but do not do so in reference to larger goals about environmental health and sustainability. Like energy efficiency requirements, these items are found in the context of traditional and non-environmental procurement policies, and were the forerunners to modern green public procurement policies. For example, policies requiring government agencies to purchase office paper that was made from recycled post-consumer materials were some the first green procurement initiatives.

As a simple example, the procurement policy for the town of Duvall, Washington requires that "the city seek to maximize purchase of products using recycled materials or products suitable for recycling." ${ }^{228}$ The Oklahoma Administrative Code states that life-cycle costs should be considered in light of

\footnotetext{
${ }^{424}$ Brookhaven, NY Code ch 7B (2009), NY Comp Codes R \& Regs title 9, § 7.4 (2008).

${ }^{425}$ Sterling, Colorado Code art IV, §19-235 (2017).

${ }^{426}$ NYC Admin Code $\S$ 6-306 (2019).

${ }^{427}$ Suwanee, GA Code of Ordinances $§ 34-512$ (2016).

${ }^{428}$ Duvall, Wash Code of Ordinances $§ 3.12 .010$ (2018).
} 
the durability and reusability of a product. ${ }^{429}$ Iowa's procurement policy encourages the purchase of biobased products with the highest percentage of biobased materials, in compliance with standards promulgated by the U.S. Department of Agriculture (though this is not surprising given the importance of corn production to the state's economy). ${ }^{430}$

\subsection{Summary}

Under jurisprudence interpreting the Commerce Clause of the U.S. Constitution, American states may use the "market participant exception" to apply environmental considerations when the government is acting as market participant by directly buying or selling goods and services. As the environmental, and perhaps economic and market, benefits of promoting ecologically preferential characteristics in goods have become more salient, states and local governments have implemented green public procurement regulations and legislation. As a result, state and local green public procurement initiatives in the U.S. often promote environmental interests through general consideration of environmental factors in a product's life cycle and/or environmentally preferable products procurement policies, encouragement of purchasing energy efficient products, and purchasing of products that are recyclable. The green public procurement efforts by the U.S. federal government lags behind the efforts of the states, though early federal policy proved influential. This is an inverted policy outcome compared to the European Union discussed in Part 7 below, in that American federal law, unlike EU law, does not dictate the parameters under which states can use GPP. In addition, implementation of GPP by U.S. government lags behind EU and its Member States.

\footnotetext{
${ }^{429}$ Okla Admin Code § 260:85-1-4 (2014).

${ }^{430}$ Iowa Code $\S 8$ A.317 (2017).
} 


\section{EU Public Procurement and Environmental Interests}

\subsection{Introduction}

A key reason behind the creation of European Union was to allow the free movement of goods and create an economic market throughout the continent. As discussed in Part 5, public procurement by Member States exerts significant influence over GDP. Businesses registered in the EU have the right to compete for public contracts in other EU countries. To create a level playing field for all businesses across Europe, EU law provides baseline harmonized rules (see Part 4 above). Now, EU Member States and contracting authorities may explicitly consider environmental considerations in procurement decisions. ${ }^{431}$ This Part 7 discusses EU public procurement law, the role of the CJEU in building the foundation for green public procurement in the EU, and the consideration of environmental characteristics in public procurement prior to the passage of the 2014 revised directive, and goes on to discuss the meaning and role of the 2014 Public Sector Directive.

\subsection{EU Public Procurement Law}

\subsubsection{Framework for EU Procurement Law Analysis}

This Part 7.2 addresses EU procurement law in three contexts. First, it recognizes that CJEU case law provided the foundation for the 2014 public procurement reforms in the EU. Second, it addresses public procurement law prior to the adoption of the 2014 Public Sector Directive ${ }^{432}$ as there was much debate over whether GPP was allowed prior to the new directive given concerns of protecting the internal market. Third, it addresses the differences in U.S. and EU law in their ability to treat public institutions as consumers in the market who may or may not seek environmentally-friendly goods when purchasing.

\footnotetext{
${ }^{431}$ See generally Bogojević (n 9).

432 Public Sector Directive (n 8).
} 
The Treaty on the Functioning of the European Union (TFEU) and the Treaty on European Union (TEU) constitute the treaties on which the European Union is founded. The Union may adopt measures with the aim of establishing or ensuring the functioning of the internal market. This market comprised an area without internal barriers in which the free movement of goods, persons, services, and capital is ensured in accordance with the provisions of the Treaties (Article 26 TFEU).

EU public procurement law is adopted with the aim of ensuring the functioning of the internal market. Important legal principles stemming from the TFEU in this regard are transparency, equal treatment, and non-discrimination. Accordingly, TFEU rules prohibit discrimination on grounds of nationality including in public procurement (for example, by reserving contracts for national suppliers). ${ }^{433}$ The now repealed 2004 procurement directive stated that in the awarding of public contracts, EU law required that,

[w] here a contracting authority grants special or exclusive rights to carry out a public service activity to an entity other than such a contracting authority, the act by which that right is granted shall provide that, in respect of the supply contracts which it awards to third parties as part of its activities, the entity concerned must comply with the principle of non-discrimination on the basis of nationality. ${ }^{434}$

These principles of non-discrimination remain in the procurement directives reformed in 2014, and the same non-discrimination principles apply to service providers who are nationals of other Member States. ${ }^{435}$

\subsubsection{CJEU Case Law Builds the Foundation for the 2014 Public Procurement Reform}

In a world needing an "all-hands-on-deck approach" to dealing with climate change, "demand-side policies" such as green public procurement can be a

\footnotetext{
${ }^{433}$ Arrowsmith, 'Introduction to the EU' (n 109) 38.

434 Council Directive 2004/18/EC art 3 [2004] OJ L134/129.

${ }^{435}$ Commission, 'Public Procurement in the European Union, Guide to the Community Rules on Public Procurement of Services Other Than in the Water, Energy, Transport and Telecommunications Sectors' (n 113) 49. The guide specifies that "the Services Directive requires that Member States and contracting authorities ensure that invitations to tender or negotiate are issued without discrimination to nationals of other Member States who satisfy the necessary requirements and under the same conditions as to its own nationals." ibid. "A provision which reserves a part of the works (or services) to tenderers having their registered office in the region where the works (or services) are to be carried out, amounts to a discrimination against tenderers from other Member States." ibid at 49 n.126 (citing Case C-360/89 Commission v Italy [1992] ECR I-3401; Case C-21/88 Du Pont de Nemours Italiana SpA. v Unità Sanitaria Locale No. 2 di Carrara [1990] ECR I-889).
} 
useful tool. ${ }^{436}$ However, under the regime of 2004 procurement directives, the inclusion of innovative, environmental and social considerations in the tender process was either not directly considered or limited in scope. Environmental and social considerations were cumulatively referred to as "secondary" and "horizontal" policies not necessarily connected with procurement's functional objective of acquiring goods, works or services.

The foundations for the more progressive approach found in the $2014 \mathrm{EU}$ procurement directives developed well before the proposal stage, ${ }^{437}$ in the shadow of the financial crisis and the Europe 2020 strategy, ${ }^{438}$ and has roots in Articles 7 through 13 TFEU. In light of the global financial crisis, public procurement reform was an effort to obtain optimal procurement outcomes to boost the economy. ${ }^{439}$ And as noted in Recital 2 of the Public Sector Directive (2014/24/EU) and its accompanying interpretative documents:

Public procurement is a key part of the Europe 2020 strategy for smart, sustainable and inclusive growth. It is one of the market-based instruments to be used to achieve the Europe 2020 objectives by improving the conditions for business to innovate and by encouraging the wider use of green procurement supporting the shift towards a resource efficient and low-carbon economy. ${ }^{440}$

But while these policy considerations played a role in the creation of the Public Sector Directive, the courts led the way. The Court of Justice of the European Union (CJEU) confirmed that social, environmental and innovative considerations can be compliant with EU public procurement law, and that these factors can be considered in public procurement as long as they do not hinder competition in the internal market. ${ }^{441}$

${ }^{436}$ Beatriz Martinez Romera and Roberto Caranta, 'EU Public Procurement Law: Purchasing Beyond Price in the Age of Climate Change' (2017) 3 EPPPL 281, 282.

${ }^{437}$ For more detailed history of genesis of the 2014 public procurement directives, see Roberto Caranta, 'The Changes to the Public Contract Directives and the Story They Tell About How EU Law Works' (2015) 52 CML Rev 391, 393-94; Sue Arrowsmith, The Law of Public and Utilities Procurement (3rd edn, vol. 1, Street \& Maxwell 2014) 182.

${ }^{438}$ Caranta, 'The Changes to the Public Contract Directives and the Story They Tell About How EU Law Works' (n 437) 394.

439 ibid.

${ }^{440}$ Commission, 'Revision of Public Procurement Directives - Frequently Asked Questions, Memo/14/20' (15 Jan 2014).

${ }^{441}$ See Andhov, 'Contracting authorities and strategic goals of public procurement - a relationship defined by discretion?' (n 167). 
The 2002 Concordia Bus ${ }^{442}$ and 2012 Dutch Coffee/Max Havelaar ${ }^{443}$ decisions played a significant role in creating room for sustainable considerations in procurement. ${ }^{444}$ The Concordia Bus case opened the way to the acceptance of non-strictly economic considerations in the award of public contracts in Directive 2004/18/EC. ${ }^{45}$ However, it was the Dutch Coffee/Max Havelaar case that was instrumental in making the significant leap forward possible in Directive 2014/24/EU, allowing anything taking place during the life cycle of a product or service to be considered so long as it is linked to the subjectmatter of the contract. ${ }^{446}$

The courts made this move despite the historically more conservative views of the European Commission, which evolved through the publication of its 2011 Green Paper on public procurement, ${ }^{447}$ and, ultimately, in the enactment of the 2014 Public Sector Directive. "The natural order of things-regulation, then case law - has been inversed in the case of sustainable procurement at the EU level: case law led the way towards the use of social and environmental considerations in public procurement, and legislation followed suit." 448

The public procurement directives have always been based on the Treaty's internal market provisions on free movement, and the CJEU has often repeated that the principal objective of the (then) Community rules in the field of public procurement is "the free movement of services and the opening-up to undistorted competition in all the Member States." ${ }^{449}$ Thus, the concern, especially by the European Commission, had existed that secondary green procurement legislation could be in conflict with even-handed competition, but, over time and through the jurisprudence (and essentially lawmaking) of the CJEU, this view has softened, leading to the 2014 procurement directives.

${ }^{442}$ Case C-513/99 Concordia Bus Finland Oy Ab v Helsingin Kaupunki et HKL-Bussiliikenne [2002] ECR I-7213.

${ }^{443}$ Case C-368/10 Commission v Netherlands [2012] ECR I-000, para 28-29 (Dutch Coffee or Max Havelaar).

${ }^{444}$ For further discussion, see Beatriz Martinez Romera and Roberto Caranta, 'EU Public Procurement Law: Purchasing Beyond Price in the Age of Climate Change' 3 EPPPL 281, 286287 (2017).

445 ibid 286, 287.

446 ibid.

${ }^{447}$ Commission, Green Paper on the Modernisation of the EU Public Procurement Policy: Towards a More Efficient European Procurement Market (2011).

${ }_{448}$ Dragos, 'Sustainable Public Procurement in the EU: Experiences and Prospects' (n 90) 303. See also ibid 303-08 (discussing Bentjees, Commission v. French Republic (Nord-Pas de Calais), Concordia (Helsinki) Bus Finland, EVN and Wienstrom, Evropaïki Dynamiki v. European Environment Agency, and Dutch Coffee/Max Havelaar).

${ }^{449}$ Caranta, 'The Changes to the Public Contract Directives and the Story They Tell About How EU Law Works' (n 437) 394-95 n.17-18. 
But the authority to consider sustainable goals begins with the Treaty itself, not Recital 2 of the Public Sector Directive. ${ }^{450}$ Caranta argues that "[i]t is therefore legitimate and makes sense when enacting rules on public contracts based on the internal market provisions of the TFEU to address issues of sustainable procurement and more specifically green procurement," and "even more so since, under Article 11, environmental protection requirements must be integrated into the definition and implementation of the EU's policies and activities, 'in particular with a view to promoting sustainable development." "'451

While the European Commission in the past has held onto the orthodoxy of keeping pure the internal market, the CJEU has helped develop law allowing for sustainable procurement ${ }^{452}$ which ultimately led to the 2014 Public Sector Directive. This is exemplified in the Concordia Bus and Dutch Coffee/Max Havelaar decisions which, when read together, allow for environmental considerations to be considered in public contracts including the production process. In this way, the 2014 procurement reforms track CJEU jurisprudence.

The Concordia Bus case (decided prior to the 2014 procurement directive revisions and even before the 2004 procurement directives) dealt with environmental award criteria in a public tender for buses in Helsinki. Concordia Bus Finland submitted the lowest-priced tender but the contract was awarded to the company offering buses with the lowest emissions. The court held that public procurement law allows contracting authorities to use criteria related to the preservation of the environment when assessing the most economically advantageous tender. ${ }^{453}$ But the CJEU conceded to internal market concerns in stating that the non-economic criteria had to be "linked to the subject-matter of the contract," a phrase found throughout the 2014 Public Sector Directive. ${ }^{454}$ This approach was affirmed in $E V N$, which concerned the procurement of green electricity in Austria, holding that public procurement does not preclude, in the electricity supply context, a contracting authority from using an award criteria requiring production from renewable energy sources. ${ }^{455}$ The emerging view is that authorities must bear in mind the public interest when

\footnotetext{
450 ibid 396 ("It is here however submitted that not all the considerations listed in Recital 2 qualify as legal bases for secondary legislation within the competences of the EU and meeting the requirements of Article 5 TEU.").

451 ibid 396-99.

452 ibid 414-15.

${ }^{453}$ Concordia Bus Finland (n 442) paras 57, 64.

454 ibid para 58. See also Caranta, 'The Changes to the Public Contract Directives and the Story They Tell About How EU Law Works' (n 437) 416 n.145, 146.

${ }^{455}$ Case C-448/01, EVN AG \& Wienstrom GmbH v Republic of Austria; Concordia Bus (n 442) para 91
} 
resorting to sustainability considerations, and limiting their ability to resort to such strategic considerations is not in line with this philosophy.

Article 53 of Directive 2004/18/EC had to a large extent codified the Concordia Bus decision. However, how the requirements (environmental considerations but related to subject matter of the contract) had to be met, however, were not clear, ${ }^{456}$ creating debate among scholars and foreshadowing the importance of the Dutch Coffee/Max Havelaar judgment and the specificity of the 2014 Public Sector Directive itself.

The Dutch Coffee/Max Havelaar case arose due to infringement proceedings filed by the European Commission against the Netherlands because the province of North Holland set an award criterion that the supplied ingredients were to bear the Eko or Max Havelaar labels. ${ }^{457}$ The CJEU held that contracting authorities are "authorised to choose the award criteria based on considerations of a social nature, which may concern the persons using or receiving the works, supplies or services which are the object of the contract, but also other persons." ${ }^{458}$ Importantly, citing the Advocate General Opinion, the Court stated that "there is no requirement that an award criterion relates to an intrinsic characteristic of a product." 459 While ultimately infringement was found as the tender required simply the label without reference to specific criteria and without allowing equivalent labels in violation of the directives at the time, ${ }^{460}$ the statements made by the court promoting sustainable purchasing and allowing the use of eco-label criteria in tendering a public contract have found their way into the 2014 Public Sector Directive in Article 67(3) via life-cycle analysis and Article 43(1) allowing contracting authorities to refer directly to the technical criteria of eco-labels and allowing eco-labels to be used as verification for these technical criteria.

\footnotetext{
${ }^{456}$ Caranta, 'The Changes to the Public Contract Directives and the Story They Tell About How EU Law Works' (n 437) 396-99.

${ }^{457}$ Dutch Coffee (n 443) para 28-29. For greater discussion of Dutch Coffee/Max Havelaar, see Malte Müller-Wrede, 'Sustainable Purchasing in the Aftermath of the ECJ's "Max Havelaar" Judgment’ (2012) 2 EPPPL 110.

${ }^{458}$ Dutch Coffee (n 443) para 85.

459 ibid para 91.

${ }^{460}$ ibid para 113.
} 


\subsubsection{EU Public Procurement Law Prior to the 2014 Public Procurement Reform}

In 2011, the European Union began considering reforms for EU public procurement law, ${ }^{461}$ and considerable debate ensued about what the revisions would actually mean and what initiatives Member States could pursue without such revisions. The objectives of the proposed directive in the classic sector (public procurement procedures for works, goods, and services) were to:

- Increase the efficiency of public spending to ensure the best possible procurement outcomes in terms of value for money. This implies in particular a simplification and flexibilisation of the existing public procurement rules . . . .

- Allow procurers to make better use of public procurement in support of common societal goals such as protection of the environment, higher resource and energy efficiency, combating climate change, promoting innovation, employment and social inclusion, and ensuring the best possible conditions for the provision of high quality social services. ${ }^{462}$

The proposed directives sought to allow Member States, in their contracting authority, to use their purchasing power "to procure goods and services that foster innovation, respect the environment and combat climate change while improving employment, public health and social conditions." ${ }^{\circ 63}$ The proposed directives suggested that the contracting authority could consider environmental factors through life-cycle analysis, eco-labeling, and sanctions for the violation of existing environmental law: ${ }^{464}$

- Life-cycle costing: The proposal gives public purchasers the possibility to base their award decisions on life cycle costs of the products, services or works to be purchased. The life cycle covers all stages of the existence of a product or works or provision of a service, from raw material acquisition or generation of resources until disposal, clearance and finalisation....

- Labels: Contracting authorities may require that works, supplies or services bear specific labels certifying environmental, social or other characteristics, provided that they accept also equivalent labels. This applies for instance to European or (multi-) national eco-labels or labels certifying

\footnotetext{
${ }^{461}$ Commission, 'Legal Rules and Implementation' < https://ec.europa.eu/growth/single-market/public-procurement/rules-implementation_en> accessed 18 Apr 2018. The original proposals are presented in COM/2011/895 final and COM/2011/896 final.

462 52011PC0896, Proposal for a Directive of the European Parliament and of the Council on Public Procurement, COM/2011/0896 final - 20011/0438 (COD) <http://eur-lex.europa.eu/LexUriServ/LexUriServ.do?uri=COM:2011:0896:FIN:EN:HTML>.

463 ibid.

464 ibid.
} 
that a product is free of child-labour. The certification schemes in question must concern characteristics linked to the subject-matter of the contract and be drawn upon the basis of scientific information, established in an open and transparent procedure and accessible to all interested parties.

- Sanctioning violations of mandatory social, labour or environmental law: Under the proposed Directive, a contracting authority can exclude economic operators from the procedure, if it identifies infringements of obligations established by Union legislation in the field of social, labour or environmental law or of international labour law provisions. Moreover, contracting authorities will be obliged to reject tenders if they have established that they are abnormally low because of violations of Union legislation in the field of social, labour or environmental law. ${ }^{465}$

Many have argued for the role of public procurement in the EU for encouraging innovation and more environmentally-friendly economic growth, ${ }^{466}$ including the imposition of mandatory standards. ${ }^{467}$

At the same time, others point out that "a fundamental requirement which must be respected in a public procurement process is that EU law is fully respected," including impartiality and non-discrimination. ${ }^{468}$ Without the market participant exception as available under U.S. law, EU Member States are not able to discriminate in favor of entities located within the contracting

465 ibid.

${ }^{466}$ Sue Arrowsmith, 'The Public Sector Directive 2004/18: Scope of Coverage' in Arrowsmith, EU Public Procurement Law: An Introduction (n 109) 119 ("Given the significant and influential role of public procurement in the economy, it is clear that it has the potential to impact on other policies (EU2020 objectives). The most frequently mentioned main areas for future strengthening of the rules are: environmental sustainability; respect for certain social conditions; and supporting innovation."); Sue Arrowsmith and Peter Kunzlik, Social and Environmental Policies in EC Procurement Law: New Directives and New Directions (Cambridge 2009); The Law of Green and Social Procurement in Europe (n 91); Hettne, "Strategic Use of Public Procurement' (n 13) 1 ("Other important interests such as social and environmental considerations can be promoted through public procurement.").

467 Jens Fejø, 'Social and Environmental Policies in EU Public Procurement Law' in Arrowsmith, EU Public Procurement Law: An Introduction (n 109) 298 ("In a recent report, the so called 'Monti Report', it is thus made one of the key recommendations to make public procurement work for innovation, green growth and social inclusion by imposing specific mandatory requirements.") (citing Mario Monti, A new strategy for the Single Market at the Service of Europe's Economy and Society, Report to the President of the European Commission José Manuel Barroso (9 May 2010) 78).

${ }^{468}$ Hettne, 'Legal Analysis' (n 13) 1. "The guiding principles were transparency, non-discrimination and impartiality. These principles should be respected when awarding contracts within the public sector." ibid 6 (citing Christopher H Bovis, EC Public Procurement: Case-Law and Regulation (Oxford 2005) 12). See also ibid 7-8 (stating that non-discrimination on basis of nationality is a key principle of EU Law) (citing Case C-324/98 Telaustria and Telefonadress [2000] ECR I-10745, para 60; Case C-59/00 Vestergaard [2001] ECR I-9505, para 20; see also Case C-264/03 Commission v France [2005] ECR I-8831, para 32; Case C-6/05 Medipac-Kazantzidis [2007] ECR I-4557, para 33). 
country. The basic requirements of EU law (here, in particular non-discrimination) must be complied with. However, more stringent national regulations in the public interest may be applied.

As result, Member States have flexibility to impose environmental standards that need not be economic considerations. The CJEU has accepted that award criteria used by the contracting authorities to identify the most economically advantageous tender need not necessarily be purely monetary.

These requirements are easier to justify than admission conditions, selection criteria, technical specifications etc., which are capable of totally excluding tenderers that cannot meet them. However, an award criterion must not be formulated so that in practice it constitutes a disguised technical specification or similar. Particular caution is required when requirements are set higher than harmonised standards in EU law. It is difficult to tell when it is possible to go beyond such standards, but it should not be excluded for instance that it is permissible to encourage technical innovation or environmental precaution that goes beyond the harmonised requirements, provided that products or services that meet the harmonised requirements are not excluded from the procurement process. ${ }^{469}$

In the absence of harmonization, EU Member States can impose national environmental requirements for certain products. ${ }^{470}$ American states can do the same, but only if not pre-empted by U.S. federal law, and so long as it would not violate the Commerce Clause of the U.S. Constitution as impeding interstate commerce. Under EU law, Member States can only create more stringent regulations if they are applied in a non-discriminatory manner, justified by imperative requirements in the general interest, suitable for securing the attainment of the objective that they pursue, and do not go beyond what is necessary in order to attain it. ${ }^{471}$

The EU is committed to internal trade harmonization, and Article 34 TFEU prohibits "[q]uantitative restrictions on imports and all measures having equivalent effect." ${ }^{, 42}$ For example, in the Danish Bottles case, the requirement that all imported bottles be re-useable was subject to Article 34 TFEU as an import restriction, and could be seen as hindering trade. ${ }^{473}$ Import bans or restrictions on dangerous products, import licensing systems, national environmental product standards and certain restrictions on the use of products affect

\footnotetext{
${ }^{469}$ Hettne, 'Legal Analysis' (n 13) 2.

470 ibid 9.

471 Case C-55/94 Gebhard v Consiglio dell'Ordine degli Avvocati e Procuratori di Milano [1995] ECR I-4165.

${ }^{472}$ See also Jan H Jans and Hans HB Vedder, European Environmental Law: After Lisbon (4th edn, Europa Law Publishing 2012) 261.

${ }^{473}$ Case C-302/86 Commission v Denmark [1988] ECR 4607, para 1, 9, 22 (Danish Bottles). See also Jans (n 472) 263
} 
the access of a product to the market and will continue to be considered a restriction on trade falling within the scope of Article 34 TFEU. 474

Similarly, there can be no national preferences under Article 34 TFEU, and products produced and marketed in one Member State must be granted access to the market in all other Member States. ${ }^{475}$ Thus, for example, import bans are unlawful unless they fall within an exception such as environmental reasons (and an analogy can be drawn to the U.S. Supreme Court case Maine v. Taylor discussed in Part 6 above).

In the EU, a trade regulation is unlawful if "the national legislation "is likely to hamper, at the very least potentially, intra-Community trade." "476 In this way the EU tests for trade hindrance begin to mirror the "undue burden" test in the U.S. context, though American states likely have more autonomy in restricting trade in the interest of the environment (compare, for example, Minnesota v. Clover Leaf Creamery discussed above with the Danish Bottles).

There are, however, exceptions to Articles 34 and 35 TFEU. According to Article 36 TFEU,

[t]he provisions of Articles 34 and 35 shall not preclude prohibitions or restrictions on imports, exports or goods in transit justified on grounds of public morality, public policy or public security; the protection of health and life of humans, animals or plants; the protection of national treasures possessing artistic, historic or archaeological value; or the protection of industrial and commercial property. Such prohibitions or restrictions shall not, however, constitute a means of arbitrary discrimination or a disguised restriction on trade between Member States.

Thus, in the Danish Bottles case, the CJEU added the protection of the environment to this list of "rule of reason" exceptions under Article 36 TFEU, which is also interpreted in light of the precautionary principle. ${ }^{477}$

Scholars suggest that the deposit-and-return system in the Danish Bottles case could probably not have been justified under Article 36 because the interests at stake - prevention of litter, energy conservation, and promotion of re-use - seem less easily encompassed by Article 36 (i.e., too narrow substantively).

The rule of reason exceptions may only be used for non-economic purposes, primarily for protection of health and the environment, ${ }^{478}$ and the CJEU has accepted the following environmental objectives under the rule of reason: "protection of birds against noise disturbances, promoting the production of

\footnotetext{
474 Jans (n 472) 267.

${ }^{475}$ Case 120/78 Rewe-Zental AG (Cassis de Dijon) [1979] ECR 649. See also Jans (n 472) 263.

476 ibid 269-70.

${ }^{477}$ Danish Bottles (n 473) paras 9, 13, 20. See also Jans (n 472) 275.

${ }^{478}$ Jans (n 472) 280.
} 
renewable energy, biodiversity, re-use and recycling of waste, protection against aircraft noise, to ensure the quality of ambient air, town and country planning, and waste disposal in line with the self-sufficiency and proximity principles." ${ }^{479}$

In public procurement, it is permissible to insert criteria based on environmental considerations as long as they are compatible with EU law in general and the subject matter of the contract in particular. Pursuant to Article 11 TFEU, as discussed in Part 4.3 above, Member State regulations must be consistent with EU policy on sustainable development.

Prior to the passage of the 2014 Public Sector Directive, the CJEU "established that contracting authorities are free to determine the factors under which the most economically advantageous offer is to be assessed and that environmental considerations could be part of the award criteria, provided they do not discriminate between alternative offers, and that they... have been clearly publicised in the tender or contract documents. ${ }^{~} 480$ But the CJEU remained concerned that including environmental factors would limit the consideration of alternatives that cannot meet these standards, ${ }^{481}$ and it remains to be seen how the CJEU interprets the 2014 Public Sector Directive. "Criteria relating to the environment, in order to be permissible as additional criteria under the most economically advantageous offer, must satisfy a number of conditions, namely they must be objective, universally applicable, strictly relevant to the contract in question, and clearly contribute an economic advantage to the contracting authority." 482 Thus, one must implicitly question whether it is appropriate to use the public procurement model to achieve environmental, rather than economic, goals, ${ }^{483}$ as opposed to general environmental regulation. That

\footnotetext{
479 ibid 275-76.

${ }^{480}$ Christopher H Bovis, EU Public Procurement Law (Edward Elgar 2007) 276-77 (citing Case C-513/99, Concordia Bus Finland Oy Ab v Helsingin Kaupunki et HKL-Bussiliikenne [2002]). "In Concordia, the Court was asked inter alia whether environmental considerations such as low emissions and noise levels of vehicles could be included amongst the factors in the most economically advantageous criterion, in order to promote certain types of vehicles that meet or exceed certain emission and noise levels." ibid 107.

481 ibid 276-77. See also ibid 279-80 (citing Case 45/87, Commission v. Ireland (1988)) ("It appears, however, that there is a limit to the permissibility of certain minimum ecological standards where the criteria applied restrict the market for the services or goods to be supplied to the point where there is only one tenderer remaining.").
}

482 ibid 277. See also ibid 279 ("The Court concluded that where the contracting authority decides to award a contract to the tenderer who submits the economically most advantageous tender, it may take criteria relating to the preservation of the environment into consideration, provided that they are linked to the subject-matter of the contract, do not confer an unrestricted freedom of choice on the authority, are expressly mentioned in the contract documents or the tender notice, and comply with all the fundamental principles of Community law, in particular the principle of non-discrimination.").

${ }^{483}$ Cf. ibid 277 ("The Court considered that in public procurement the criteria for the decision must always be of an economic nature. If the objective of the contracting authority is to satisfy 
said, the protection of the environment can be included amongst the factors that determine the most economically advantageous offer, and Article 11 TFEU (previously Article 6 in the Treaty of the European Community) requires environmental protection to be integrated into the other policies of the Union (see Part 4.3 above). ${ }^{484}$

During the proposal stage for the 2014 procurement directives, scholarly debate arose as to how the CJEU should and would determine whether a given procurement rule violates the TFEU. Hettne, proposed that because procurement "basically expresses fundamental internal market principles," whenever a procurement rule involves "cross-border interest," it should be interpreted in terms of whether it restricts one of the "four freedoms of movement-of good, persons, services and capital, ${ }^{485}$ as well as the principle of harmonization. ${ }^{486}$ In the context of discussing the relevant factors that the CJEU would use to determine whether a procurement rule violates internal market principles, Hettne discussed the principle of proportionality that is typically applied to the analysis of trade restrictions. ${ }^{487}$

The two-part proportionality test asks whether the restriction is "suitable to achieve a legitimate aim" and whether it is "necessary to achieve that aim" (whether it is the least restrictive way to achieve the aim in U.S. legal terms). ${ }^{488}$ Pursuant to the Gebhard case, restrictions of trade must be applied in a non-discriminatory manner, justified by imperative requirements in the general interest, suitable for securing the attainment of the pursued objective and not go beyond what is necessary in order to attain its purpose. ${ }^{489}$ This test would apply not only to a Member State's regulatory restriction of trade, but

ecological or other considerations, it should have recourse to procedures other than public procurement procedures.").

${ }^{484}$ See ibid 277. See also ibid 278 (citing Beentjes, para 19; Evans Medical and Macfarlan Smith, para 42; SIAC Construction, para 36) ("In the light of Article 130r(2) EC and Article 6 $\mathrm{EC}$, which lay down that environmental protection requirements must be integrated into the definition and implementation of Community policies and activities, the Court concluded that Article 36(1)(a) of Directive 92/50 does not exclude the possibility of the contracting authority using criteria relating to the preservation of the environment when assessing the economically most advantageous tender. However, that does not mean that any criterion of that nature may be taken into consideration by contracting authorities. While Article 36(1)(a) of Directive 92/50 leaves it to the contracting authority to choose the criteria on which it proposes to base the award of the contract; that choice may, however, relate only to criteria aimed at identifying the economically most advantageous tender.").

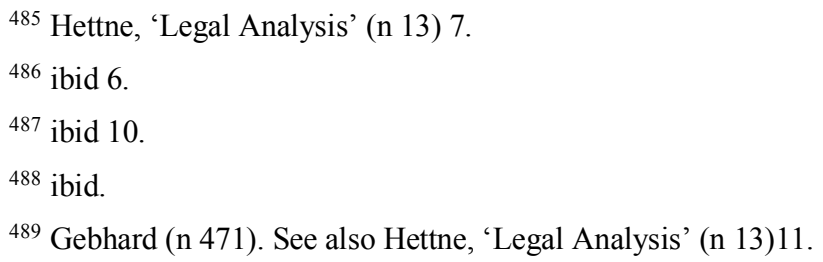


also to public procurement policies that could have the effect of restricting trade. ${ }^{490}$

In Contse, a Spanish authority soliciting contracts for home respiratory equipment required that potential tenderers maintain offices in specified towns, and one award criterion was that the tenderer operate production facilities within 1000 kilometers of the province. ${ }^{491}$ For Hettne, Contse demonstrates that the Gebhard test applies to procurement rules, and that the CJEU will add an additional test: whether the criteria are "linked to the objective of the contract and are suitable for ensuring that it is attained." 492 Thus, Hettne states:

Neither the new provisions in the EU Treaties regarding environmental and social considerations nor the proposed directive on public procurement alter the present legal situation. However, these developments underline that the EU pursues a multitude of interests which are not only economic. The possibility for the Member States to promote environmental or social interests in public procurement in support of existing EU legislation is therefore increased. ${ }^{493}$

So, while Hettne supported the proposed directives, he viewed them as merely restating existing law, ${ }^{494}$ but argued they are symbolically important in reaffirming and suggesting that environmental and social considerations can be made in the public procurement process. ${ }^{495}$ Hettne believed, prior to the pas-

\footnotetext{
${ }^{490}$ Case C-234/03, Contse et al v Ingesa [2005] ECR I-9315, para 25. See also Hettne, 'Legal Analysis' (n 13) 11.

${ }^{491}$ Contse (n 490). See also Hettne, 'Legal Analysis' (n 13) 25.

${ }^{492}$ See also Hettne, 'Legal Analysis' (n 13) 31.

493 ibid 2 .

${ }^{494}$ Hettne, 'Strategic Use of Public Procurement' (n 13) 10 (The CJEU "has accepted, more or less explicitly, that when the contracting authority decides to award a contract to the tenderer who submits the most economically advantageous tender it may take into consideration environmental or social criteria, provided that they are linked to the subject matter of the contract, do not confer an unrestricted freedom of choice on the authority, are expressly mentioned in the contract documents or the tender notice, and comply with all the fundamental principles of Union law, in particular the principle of non-discrimination.").

495 ibid 13 ("I therefore conclude that the 'strategic use of public procurement' is associated with corresponding limitations that applied previously under EU law. Accordingly, the new Directive does not alter the present legal situation (outside the procurement Directives), which means that contracting authorities which impose environmental and social requirement must respect EU law in general (the criteria used must be applied in a non-discriminatory manner, must be justified by imperative requirements in the general interest, must be suitable for securing the attainment of their objective, and must not go beyond what is necessary in order to attain that objective). However, these developments underline the fact that the EU pursues a multitude of interests which are not only economic ones. The possibility for the Member States to promote environmental or social interests in public procurement in support of existing EU legislation will therefore increase.").
} 
sage of the 2014 reforms, that it was permissible to take non-economic concerns into account in public procurement without violating EU internal market law by defining the object (i.e., what to buy) carefully, by closely relating the concerns to other developments in EU law and policy (e.g., progress in the environmental field), and using award criteria rather than obligatory conditions.

Hettne additionally argued that the principle of harmonization must be considered when evaluating procurement rules. The EU may issue directives that indicate "total" or "minimum" harmonization in a given field. ${ }^{496}$ With a totally harmonized rule, a Member State may not restrict movement of goods that meet the requirements of the rule, and may not allow products that fail to meet the requirements; with minimum harmonization, the Member State must respect the minimum level but may develop stricter standards than the EU directives in certain fields, such as environmental protection, labor conditions, and consumer protection. ${ }^{497}$ Hettne cited Medipac as an example of the CJEU's application of harmonization principles to procurement policies. ${ }^{498} \mathrm{In}$ Medipac, a public hospital set a higher standard for surgical sutures than the $\mathrm{EU}$ (which required only the CE marking). ${ }^{499}$ The CJEU ruled against the hospital's procurement rule because it "question[ed] the validity" of the totally harmonized rule that deemed CE certified sutures acceptable. ${ }^{500}$

Caranta and Kunzlik criticized Hettne's argument that case law supports the complex assessment of procurement rules based on the Gebhard rule and harmonization. Caranta argued that environmental and social considerations may be inscribed in procurement rules more liberally than in regulations by Member States precisely because the CJEU will not apply the general interest prong of the test as outlined by Hettne. ${ }^{501}$ Contse, according to Caranta, has been infrequently cited in the subsequent case law and should not be taken as an indication that the CJEU will apply internal market principles when analyzing other procurement rules. ${ }^{502}$ Kunzlik followed Caranta's lead and further clarified that after considering whether a procurement rule has a "cross border interest," the CJEU will inquire whether the rule relates to "what to buy" or "access to the contract" decisions. ${ }^{503}$

\footnotetext{
${ }^{496}$ Hettne, 'Legal Analysis' (n 13) 24.

497 ibid 27.

498 ibid 28 (citing Case C-6/05 Medipac-Kazantzidis [2007] ECR I-4557).

${ }^{499}$ Case C-6/05 Medipac-Kazantzidis [2007] ECR I-4557.

500 ibid para 43. See also Hettne, 'Legal Analysis' (n 13) 30.

${ }^{501}$ Roberto Caranta, On Jörgen Hettne's Legal Analysis of the Possibilities of Imposing Requirements in Public Procurement that Go beyond the Requirements of EU Law (n 13) 1.

502 ibid 1-3.

${ }^{503}$ Kunzlik (n 13) 2.
} 
Citing Concordia Bus Finland, Kunzlik argued that when a rule relates to "what to buy," rather than "access to the contract," the CJEU has upheld procurement rules that are non-discriminatory and transparent. ${ }^{504}$ Kunzlik pointed to further case law to underscore that the CJEU has declined to consider the degree to which a procurement rule actually achieves its goal. ${ }^{505}$ Contradicting Hettne's argument that the Gebhard test, including the proportionality test, applies to procurement rules, Kunzlik further argued that Medipac does not stand for the proposition that harmonization principles apply to procurement rules; rather, the CJEU struck down the hospital's rule because the hospital had not been transparent about the technical specification for the sutures, and had originally allowed for sutures that bore the CE marking. ${ }^{506}$

Kunzlik emphasized that to apply harmonization principles to the analysis of procurement rules would be "perverse" because it would "distort competition in the internal market by preventing innovative firms from reaping the rewards of responding to demand by means of dynamic competition: in short, it would rig the internal market, so far as public contracts are concerned, in favour of less innovative firms. ${ }^{" 507}$ According to Kunzlik, the test for procurement rules was whether (1) the rule is non-discriminatory and (2) transparent. Kunzlik argued that if the proposed directive were enacted, the test would add the element of proportionality, thus bringing it closer to Hettne's description of the current test. ${ }^{508}$

While apparently opposed on their face and based on different perspectives, the arguments outlined by Hettne and Caranta/Kunzlik may not be so inconsistent in practice as all accept that using environmental and social considerations in public procurement was permissible (and clearly allowable under the 2014 Directive). However, the debate highlights the absence of CJEU jurisprudence on procurement rules and/or disagreement among scholars in interpreting existing case law. ${ }^{509}$ Kunzlik's distinction between "what to buy" and "access to contract," essentially paralleled Hettne's distinction between "admission conditions" and "evaluation criteria," 510 and can be compared to the distinction between the state as regulator and the state as market participant in American dormant commerce clause jurisprudence. A comparison can also be seen in Hettne's claim that contracting authorities must carefully define what

\footnotetext{
504 ibid 2-3 (citing Concordia Bus Finland).

505 ibid 3 (citing $E V N$ ).

506 ibid 5.

507 ibid 7.

508 ibid 8.

${ }^{509}$ Hettne, 'Strategic Use of Public Procurement' (n 13) 17 ("Overall, it is difficult to give a clear answer regarding how much space contracting authorities have at their disposal in order to support social or environmental objectives.").
}

${ }^{510}$ Hettne, 'Legal Analysis' (n 13) 31. 
they really want (the subject matter). According to Hettne, in some cases it may be perfectly legitimate to define the object of the contract to a very narrow category of goods or services and also to specify that a particular social or environmental policy is the object of the procurement process. ${ }^{511}$

The fundamental difference between the European and American distinctions is that the CJEU will not uphold rules that are discriminatory even if they are "what to buy" (i.e., "market participant") decisions, whereas American courts will allow discriminatory restrictions on interstate trade as long as a state is acting as a market participant rather than as a regulator.

As a result of this public procurement debate under EU law, Hettne was correct when he asserted that:

A question that should therefore be raised is whether the [2014 Public Sector] Directive actually allows more room for environmental and social considerations than has hitherto been the case. ${ }^{512}$

Caranta and Kunzlik's past, and perhaps current, view of the law creates greater "federalism" in the EU in allowing environmental considerations to play a role in public procurement and thus the 2014 Directive may actually raise the barriers to "environmental federalism." Meanwhile, Hettne, in viewing the proposed directive as simply codifying current law, is far more concerned with undermining the EU internal market. ${ }^{513}$

In any event, the 2014 Public Sector Directive, discussed below, clearly and explicitly allows environmental considerations to play an increased role in procurement decisions and, thus, the final version, in its scope and breadth, should be interpreted to outstrip Hettne's concerns. The 2014 Public Sector Directive should persuade EU Members to actually implement the directive allowing for GPP rather than maintaining an inactive state in light of the previous legal debates about to what extent Member States can import environmental considerations into public procurement decisions. The Hettne-Caranta/Kunzlik debate about what was allowed in the past and what the reforms would do remains very relevant in light of potential future interpretations by the CJEU.

\footnotetext{
${ }^{511}$ Hettne, 'Strategic Use of Public Procurement' (n 13) 13.

512 ibid 12

513 ibid 18 ("Contracting authorities within the EU can therefore not be given full freedom to set social and environmental requirements for the award of a public contract. Such a development would undermine the internal market which the EU has built up with great effort during a period of more than 50 years, since a relatively large share of the total trade in the market is covered by public contracts.").
} 


\subsubsection{Comparing EU and U.S. Law as it Relates to the Market Participant Exception and Environmental Considerations in Public Procurement}

The dominant legal and policy question in comparing U.S. and EU law as it relates to public procurement, geographic restrictions and the environment is whether it is better (and lawful) for states to create general environmental standards to achieve ecological goals or to do so through use of a market participant exception or green public procurement. Granted, these options are not mutually exclusive, though there is certainly a modern trend of choosing neoliberal market-based regulation over traditional public regulation.

The market participant option, both in terms of states preferring goods from local sources or goods with certain environmental characteristics, exists in the U.S. In virtually any public procurement decision the dormant commerce clause analysis does not apply, and, thus, the decision will not be struck down, though it may lead to retaliatory measures from other states. ${ }^{514}$

Any such similar broad-based market participant exception in the realm of public procurement would be problematic in the EU. Unlike the market participant exception in U.S. law, when EU Member States enter the market through public procurement, national law favoring local products (though perhaps with questionable positive ecological impacts) would clearly violate EU trade law, likely so even if the sole justification is the environmental interests of having lower traveling distances across the supply chain. ${ }^{515}$ However, the inclusion of preferences to promote stronger environmental interests proves a more complex and useful case, especially in light of the 2014 Public Sector Directive.

A market participant exception allowing discrimination in favor of entities from an EU Member State would contradict a goal of European integration, namely that national regulations not be proxies for national economic protectionism. ${ }^{516}$ It has been noted that there are arguments in favor of allowing such a market participant exception for Member States. "Should not contracting authorities at least under certain circumstances be considered as simply purchasers and be entitled to buy what they want?"517 Why should decisions on whether to make a purchase and what to purchase be treated as hindrance to

\footnotetext{
${ }^{514}$ See Karl Manheim, 'New-Age Federalism \& Market Participant Doctrine (1990) 22 Arizona State LJ 55.

515 Clune (n 31) 26-27.

${ }^{516}$ Hettne, 'Legal Analysis' (n 13) 9 ("This meaning of the prohibition of discrimination was very important in the past because there was a significant element of national protectionism concealed in national regulations when the European integration process began.").

517 ibid 37.
} 
trade, even when they are discriminatory in effect? ${ }^{518}$ Regardless, consistent with the view of other scholars, ${ }^{519} \mathrm{EU}$ law contains no market participant exception for its Member States in relation to geographic preferences, and a market participant exception in the EU would not be possible because the standards of so many goods are harmonized. However, EU law and the 2014 Public Sector Directive allow EU Member States to include environmental considerations, to the extent they relate to economic outcomes, in the public procurement process. ${ }^{520}$ Member States may narrow their choices (e.g., to ecofriendly goods) within existing parameters.

The next issue then is, absent a market participant exception, can American states and EU Member States create general state/national regulations requiring environmental characteristics for the product to be involved in the state's commerce, or, more narrowly, could such standards merely be adopted in the scope of public procurement? Looking at the United States, Farber states:

\begin{abstract}
Most state legislation is neither proprietary nor discriminatory... State legislation of this kind is not as suspect as legislation that is discriminatory on its face, in its intent or in its application. Nevertheless, there is a real risk that a state may pass legislation without adequately considering its impact elsewhere in the country. In addition, the risk also exists that a state will use what appears to be nondiscriminatory legislation as a covert means of burdening out of state businesses. ${ }^{521}$
\end{abstract}

A U.S. state, absent preemption by federal law, can adopt "even-handed" regulation or legislation that leads to environmental benefits, ${ }^{522}$ unless the burdens of the law are clearly excessive compared to the benefits (i.e., the Pike test discussed in Part 6 above)..$^{523}$

The 2014 EU Public Sector Directive certainly allows Members States to create even-handed environmental criteria for purchasing within the scope and

\footnotetext{
518 ibid.

519 ibid 38 ("However, in my opinion, this view is not supported by the present state of Union law which does not contain a market-participant exception and has a different objective and origin than American law.”).

${ }^{520}$ Commission, Buying Green! A Handbook on Green Public Procurement (3rd edn, 2016); Commission, Buying Social: A Guide to taking account of social Considerations in Public Procurement (2010).

${ }^{521}$ Farber (n 345) 11-12, 21. A leading example of its application is Kassel v. Consolidated Freightways Corporation. 450 US 662 (1981) (striking down state restrictions on the use of certain extra-long truck-trailer combinations).

${ }^{522}$ Clover Leaf Creamery Co (n 226) 456 (upholding environmental regulation requiring biodegradable milk bottles); Exxon Corp v Maryland 437 US 117 (1978) (upholding state law prohibiting producers from operating retail gas stations and requiring gasoline suppliers to extend uniform price reductions to all stations they supply).
}

${ }^{523}$ Pike (n 252) 137. 
context of public procurement. An EU Member State could also adopt general environmental regulations for products and services, though it may perhaps face even greater risk than its American counterparts of preemption by EU law given the baseline treaty obligations and concerns over internal trade harmonization.

Analysis reveals that the two systems are actually more similar than different. While the market participant exception remains a legal non-starter for Member States within the EU, both American states and EU Member States can take environmental criteria into consideration when engaging in public procurement. The EU administrative burdens are greater in the absence of the market participant exception, though these barriers are greatly reduced in light of the 2014 Public Sector Directive, and both can pass generally applicable environmental legislation (if not pre-empted and not used as a disguise for discriminatory economic protectionism).

In terms of generally applicable laws, American states remain subject to federal preemption and the Pike test-environmental laws are upheld unless they place an undue burden on interstate commerce. ${ }^{524}$ Similar to Pike, under the EU Gebhard factors, Member States can only create more stringent regulations if they are applied in a non-discriminatory manner, justified by imperative requirements in the general interest, suitable for securing the attainment of the objective which they pursue, and do not go beyond what is necessary in order to attain it. ${ }^{525}$

Thus, the market participant exception/public procurement debate arises against a backdrop of the conflict between environmental protection/social justice and the free movement of goods (or what might be otherwise stated as American commerce clause/EU internal market concerns), and continues the general debate of whether an American state or EU Member State is acting as a market participant versus state as a market regulator.

Going further, while using public procurement to achieve environmental gains may have a better chance for survival under Kunzlik's interpretation of the law, if such decisions have to go through the Gebhard test (under Hettne's interpretation or as a result of the 2014 directive), then such use may be functionally market regulating anyway. Or, if the 2014 Public Sector Directive has in fact ended this debate, would its implementation in a market sector dominated by government purchasing be functional governmental regulation? In other words, does or can public procurement have so much impact that it is subject to harmonization? Is then general environmental regulation that is automatically subject to harmonization the better route?

Stated another way, if a state wants to buy widgets made of recycled materials, this is certainly related to the subject matter of the contract and may be

\footnotetext{
524 ibid 142.

${ }^{525}$ Gebhard (n 471).
} 
a permissible inclusion of environmental considerations in public procurement under any interpretation of the law (whether Hettne's or the linked to the subject matter of the contract requirement in the 2014 Directive discussed below) due to its narrow and specific scope. But requiring life-cycle analysis for the widgets implicates much more (e.g., factory outputs, raw material inputs, and disposal) and raises the issue of creating hindrances in the internal market. Going further, a Member State that passes a regulation or law that demands recycled materials or life-cycle analysis of all widgets sold in the country clearly raises harmonization concerns, though this may be the preferred route from a pure public policy standpoint. While all of this was previously questionable, the text of the 2014 Public Sector Directive may make this all permissible.

This conflict between environmental protection and free movement of goods (market protection) is traditionally managed in different ways depending on whether there is total harmonization for the benefit of market interest (e.g., high EU-wide environmental standard), ${ }^{526}$ minimum harmonization (e.g., low baseline EU-wide environmental standard that Member States can make stricter), or potential conflict with the EU treaty despite the lack of EU regulatory standards..$^{527}$ Thus, prior to the 2014 Public Sector Directive, the question remained to what extent, pursuant to EU procurement or preemption law, Member States could promote environmental sustainability through purchase and legislation. This question persists in the U.S., though the doctrines remain less opaque compared to the EU.

Despite its risks, the market participant exception has proven relatively successful in the United States in promoting local interests, including the environment, and local economies, with a growing interest in promoting local food systems. American states should endeavor to become more creative in establishing ecological criteria for public procurement in taking advantage of this exception to the dormant commerce clause analysis. However, the geographic preferences often used in market participant exceptions under U.S. law are antithetical to many of the underlying goals of the founding of the European Union. With the revisions in EU public procurement law, it will be worthwhile for the EU Member States to experiment with even greater inclusion of environmental criteria in their formalized and non-discriminatory public procurement process.

The EU might also increase general environmental standards for all durables and consumables within the EU, making them applicable to all Member States to ensure environmental sustainability in the life cycle of all products. The same could be said for the U.S., but the EU's founding documents provide

\footnotetext{
${ }^{526}$ In the so-called Salmonella case, Case C-111/03 Commission v Sweden [2005] ECR I-8789, the CJEU ruled that Sweden could not conduct further inspection of imported meat and eggs because EU law was fully harmonized in that area.
}

${ }^{527}$ See Jans (n 472) 251-94. 
a much better foundation for environmental protection compared to the U.S., which has passed very few environmental laws since the environmental legislation boom of the 1970s.

Given that new, national environmental legislation remains unlikely due to the nature of governmental structures, the potential role of environmental federalism remains greater in the United States than Europe. American states should begin to increase environmental standards when products enter state borders to further the economic and environmental interests of the states. The EU should continue to support EU-wide environmental law and regulation. Regardless of the future of U.S. federal environmental legislation and EU environmental law, both American states and EU Member States can and should take environmental considerations into account in the public procurement process.

Whether or not the market participant exception really gives an advantage to the U.S. in allowing states to use procurement rules to achieve environmental improvements depends on the Hettne-Caranta/Kunzlik debate. If Hettne is correct that the case law indicates that procurement policies, in the absence of a market participant exception, will be analyzed according to the relatively strict requirements of the Gebhard test and must be attuned to the level of harmonization regarding the good or service that is contracted, then it is true that Member States may have been limited in using procurement rules to pursue environmental policies, and, thus, the 2014 Public Sector Directive lessens (even if symbolically) such limitations. This counseled in favor of the enactment the directive in order to make clear to contracting authorities can engage in GPP.

Case law regarding the construction of EU procurement law and the harmonization of technical regulations in public procurement suggests that Hettne's view of the law is sound, and passage of the Public Sector Directive was important in order for Member States to fully consider non-economic considerations in public procurement. ${ }^{528}$ In addition to language in the Preamble to the 2014 Public Sector Directive and pursuant to the CJEU's ruling in Medisanus, the application of the procurement directives does not exclude application of primary law, ${ }^{529}$ and the outcome in Medipac, confirmed in Commission v. Greece, indicates that contracting authorities must pay attention to harmonized rules. ${ }^{530}$ In other words, primary law and the fundamental rules of the internal market cannot be disregarded in the public procurement context, and, from an internal market perspective, a contracting authority must take

\footnotetext{
528 Jörgen Hettne, 'Public Procurement and European Standards: Fair Competition or Limits to Discretion' 144-148, 156-159 in Bogojević, Discretion in EU Public Procurement Law (n 9).

${ }^{529}$ Case C-296/15 Medisanus EU:C:2017:431, para 71-72. See also ibid 144-145.

${ }^{530}$ Case C-489/06 Commission v Greece EU:C:2009:165; Case C-6/05 Medipac-Kazantzidis [2007] ECR I-4557. See also Hettne, 'Public Procurement and European Standards: Fair Competition or Limits to Discretion' (n 528) 147-148.
} 
account of and respect harmonized EU rules related to the subject matter of the contract. ${ }^{531}$

If, on the other hand, Caranta and Kunzlik are correct that the Contse case does not indicate that the CJEU will analyze procurement rules under internal market principles (especially proportionality), and that the Medipac case does not indicate that the CJEU will subject procurement rules to analysis under the principles of harmonization, then case law would have already allowed for Member States to use procurement rules to achieve environmental goals.

Thus, the question becomes: Was the 2014 Public Sector Directive promoting GPP necessary, or might it create more harm than good in promoting environmental considerations in public procurement? Moreover, while Hettne interpreted the procurement reforms as strengthening (at least symbolically) the ability of Member States to restrict trade in the name of environmental considerations, Kunzlik argued that the reforms actually add the proportionality criteria. So, the issue of the implications of the 2014 Public Sector Directive rests on both interpretation of EU law and the views about the importance of conformity within the internal market.

In the view of this thesis, the 2014 Public Sector Directive added both a general subject matter of the contract requirement (it already existed for award criteria only after Concordia Bus) and the proportionality criterion, but any negatives of these added limitations are substantially offset by the value of making it clear to contracting authorities that they can pursue green public procurement, especially in light of case law supporting Hettne's legal conclusions discussed above. However, despite the emergence of GPP, environmental interests may be better achieved through more direct and general regulation of the goods and services in question. Standing in the way of the success of such regulations are the high bars set by the dormant commerce clause and preemption doctrine in the U.S. and the internal market principles and harmonization doctrine in the EU. If states are to create innovative solutions to environmental problems, the evaluation of restrictions of trade must grant more weight to environmental standards as a legitimate government interest. The EU has now explicitly done this with passage of the 2014 Public Sector Directive. ${ }^{531}$ Hettne, 'Public Procurement and European Standards: Fair Competition or Limits to Discre-
tion' (n 528) 145, 148. 


\subsection{The 2014 Public Sector Directive and Green Public Procurement}

\subsubsection{Public Procurement Reform of 2014}

The European Union has adopted revisions for EU public procurement law. ${ }^{532}$ In December 2011, the Commission proposed the revision of Directives 2004/17/EC (procurement in the water, energy, transport and postal services sectors) and 2004/18/EC (public works, supply and service contracts), as well as the adoption of a directive on concession contracts. The directives were voted on by the European Parliament in January 2014 and adopted by the Council in February 2014, and three new instruments were enacted: Directive 2014/23/EU on concession contracts, Directive 2014/24/EU on public sector procurement, and Directive 2014/25/EU on procurements in the utilities sectors. ${ }^{533}$ "The directives lay down the rules which will apply to public contracts passed by the covered authorities and entities in the Member States."534 The Member States had until April 2016 to transpose the new rules into their national law. This thesis, and Part 7.3 in particular, focuses on the public sector procurement directive, Directive 2014/24/EU, and the green/sustainability components of that Directive ("Public Procurement Directive" or "Public Sector Directive" or "Directive").

The objectives of the 2014 Public Sector Directive in the classic sector (public procurement procedures for works, goods and services) were to increase the efficiency of public spending, and allow procurers to make better use of public procurement in support of common societal goals such as protection of the environment, higher resource and energy efficiency, combating climate change, promoting innovation, employment and social inclusion, and ensuring the best possible conditions for the provision of high quality social services. $^{535}$

The Directive seeks to allow Member States to use their purchasing power "to procure goods and services that foster innovation, respect the environment and combat climate change while improving employment, public health and

\footnotetext{
532 Commission, 'Public Procurement: Legal Rules and Implementation' < https://ec.europa.eu/growth/single-market/public-procurement/rules-implementation_en> accessed $17 \mathrm{Apr}$ 2018.

${ }^{533}$ Concessions Directive (n 8); Public Sector Directive (n 8); and Utilities Directive (n 8). See also Caranta, 'The Changes to the Public Contract Directives and the Story They Tell About How EU Law Works' (n 437) 391.

${ }^{534}$ Caranta, 'The Changes to the Public Contract Directives and the Story They Tell About How EU Law Works' (n 437) 391.

535 52011PC0896, 'Proposal for a Directive of the European Parliament and of the Council on Public Procurement' (n 462).
} 
social conditions." 536 The Directive suggests that the contracting authority can consider environmental factors through life-cycle costing, eco-labeling criteria, and sanctions for the violation of existing environmental law. ${ }^{537}$

\subsubsection{The Details of the 2014 Public Sector Directive}

The Recitals of Directive 2014/24/EU on public procurement (which repealed Directive 2004/18/EC ${ }^{538}$ ) lay out why public contracts play "a key role in the Europe 2020 strategy" and are useful "market-based instruments to be used to achieve smart, sustainable and inclusive growth while ensuring the most efficient use of public funds." ${ }_{339}$ Going further, the Directive makes clear that environmental and social considerations should be incorporated in the public procurement procedures of the Member States and contracting authorities. ${ }^{540}$

The new directives have gone a long way in empowering contracting authorities to engage in sustainable procurement and more specifically in green procurement, to a certain extent lowering the regulatory risks attached to this approach under the 2004 directives. As has been remarked, the "sustainability paradigm is almost taking over the realm of public procurement, and it is marketed as a major 'selling point' of the new legislation." ${ }^{\text {44 }}$

Thus, the Directive makes green public procurement "more mainstream," though the success of the directive will depend on the implementation and political will of national governments and contracting authorities. ${ }^{542}$

\footnotetext{
536 ibid.

537 ibid. See also Commission, 'Public Procurement Reform Factsheet No. 7: Green Public Procurement' (n 88) 1-2.

${ }^{538}$ For discussion of green public procurement before the new directives, see The Law of Green and Social Procurement in Europe (n 91) 15-51.

${ }^{539}$ Council Directive (n 8) Recital 2.

${ }^{540}$ Public Sector Directive (n 8) Recital 37 ("With a view to an appropriate integration of environmental, social and labour requirements into public procurement procedures it is of particular importance that Member States and contracting authorities take relevant measures to ensure compliance with obligations in the fields of environmental, social and labour law that apply at the place where the works are executed or the services provided and result from laws, regulations, decrees and decisions, at both national and Union level, as well as from collective agreements, provided that such rules, and their application, comply with Union law.”).

${ }^{541}$ Caranta, 'The Changes to the Public Contract Directives and the Story They Tell About How EU Law Works' (n 437) 397 (citing Dragos, 'Sustainable Public Procurement in the EU: Experiences and Prospects' (n 90) 304).
}

${ }^{542}$ Semple, A Practical Guide (n 179) 171. 
The result is that the 2014 Public Sector Directive contains "provisions which are innovative in many respects." ${ }^{943}$ These provisions include: (1) a horizontal clause, under Article 18, requiring that in the performance of public contracts economic operators comply with all environmental, social and labor obligations stemming from EU, international, and national law; (2) under Article 67(3), an expansive view of what is linked to the subject matter of contract in environmental criteria, allowing consideration of all points of the production process; (3) allowing award criteria to refer directly to the inclusion of eco-labels and their criteria; and (4) the emergence of life-cycle costing as a way to determine the true cost of a tender. Under Article 67(1) addressing contract award criteria, "contracting authorities shall base the award of public contracts on the most economically advantageous tender," ${ }^{544}$ and Article 67(2) permits the use of life-cycle costing as a basis for this approach. ${ }^{545}$ In particular, the development of eco-labeling requirements and life-cycle costing methodology may result in significant innovation, though complex implementation. ${ }^{546}$

\subsubsection{Horizontal Clause}

The horizontal clause in the Directive, Article 18(2), requires compliance with applicable environmental, social, or labor law obligations under EU or national law, collective agreements, or international law. ${ }^{547}$ Member States and public authorities are expected to monitor compliance, and any operators found to be out of compliance can be excluded from public tendering procedures. ${ }^{548}$ In addition, in terms of selection criteria, Article 57(3) and Recital 40

${ }^{543}$ Caranta, 'The Changes to the Public Contract Directives and the Story They Tell About How EU Law Works' (n 437) 391.

${ }^{544}$ Public Sector Directive (n 8) art 67(1).

${ }^{545}$ Public Sector Directive (n 8) art 67(2).

${ }^{546}$ Caranta, 'The Changes to the Public Contract Directives and the Story They Tell About How EU Law Works' (n 437) 391 (noting that the rules are "very complex, and at times obscure, making this area even more technical that it already was").

${ }^{547}$ Public Sector Directive (n 8) art 18(2) states: "Member States shall take appropriate measures to ensure that in the performance of public contracts economic operators comply with applicable obligations in the fields of environmental, social and labour law established by Union law, national law, collective agreements or by the international environmental, social and labour law provisions listed in Annex X."

${ }^{548}$ Commission, New Rules on Public Contracts and Concessions: Simpler and More Flexible 8-9 (2014) ("They will be allowed to evaluate bids on the basis of broader parameters: . . . Any abnormally low bid will be rejected if it indicates a failure to observe social, labour law or environmental protection obligations."); See also Commission, 'Public Procurement Reform Factsheet No. 7: Green Public Procurement' (n 88) 1 ("In the performance of public contracts enterprises have to comply with the applicable environmental obligations stemming from EU, international and national law. An enterprise which does not respect these environmental obligations can be excluded from the tender procedure. The enterprise that has submitted the best 
allow economic operators to be excluded for not following EU and national environmental law.

This rule is key in the public procurement process as contracted businesses will have to comply with strong environmental and, in particular, labor rules of the contracting Member States. Thus, under the Article 18(2) horizontal clause, all EU environmental legislation (e.g., waste, energy, water, electronics, vehicles, and certification) and social legislation (e.g., employment, equality, disability, and health and safety) apply to the procurement process. ${ }^{549} \mathrm{Ar}-$ ticle 18, to which Recital 37 refers, is the only instance in which sustainable public procurement is clearly mandated, seeking to ensure a level economic playing field. Article 18(1) also cemented the views of the CJEU that EU rules must be complied with as "[c]ontracting authorities shall treat economic operators equally and without discrimination and shall act in a transparent and proportionate manner."

\subsubsection{Linked to the of Subject of the Contract Requirement}

Under Article 67(1) of the 2014 Public Sector Directive addressing contract award criteria, "contracting authorities shall base the award of public contracts on the most economically advantageous tender," $" 550$ and Article 67(2) permits the use of life-cycle costing as a basis for this approach. ${ }^{551}$ However, any environmental aspects considered must be "linked to the subject-matter of the public contract in question."'552 Directive 2014/24/EU greatly broadens, continuing the path of the Dutch Coffee/Max Havelaar decision, what is considered linked to the subject matter of the contract (LtSC). Under Article 67(3),

Award criteria shall be considered to be linked to the subject-matter of the public contract where they relate to the works, supplies or services to be provided under that contract in any respect and at any stage of their life cycle, including factors involved in:

(a) the specific process of production, provision or trading of those works, supplies or services; or

\footnotetext{
tender may be not awarded the contract if the tender does not comply with these environmental obligations.").

${ }^{549}$ Semple, A Practical Guide (n 179) 174-75 tbls $7.1 \& 7.2$.

${ }^{550}$ Public Sector Directive (n 8) art 67(1).

551 ibid art 67(2) (emphasis added).

552 ibid art 67(3).
} 
(b) a specific process for another stage of their life cycle, even where such factors do not form part of their material substance. ${ }^{553}$

Thus, contracting authorities can not only consider the ingredients/materials that make up the product being purchased, but also, like the $E V N$ case, can consider everything that goes into the production process of specific good or service. ${ }^{54}$ This links perfectly to the consideration of the life cycle of a good or service where you can consider environmental design characteristics, ${ }^{555}$ all stages of the life cycle of the process (acquisition, use costs, maintenance, and disposal), ${ }^{556}$ and any environmental externalities. ${ }^{557}$

Contracting entities can obviously consider the use of environmentally friendly materials as a determining factor in the choice of contractor. ${ }^{558}$ But the European Commission has also provided examples of how to accomplish the consideration of all factors of the production process, provision, or trading, even where such factors do not form part of the material substance of the product, and assessing value for money on the basis of environmental aspects. ${ }^{559}$ For example, "when technically describing the products or services they want to purchase, they may require that they do not involve toxic chemicals or are produced/provided using energy-efficient machines," and public purchasers can assess "whether books were printed on recycled paper or paper from sustainable timber." ${ }_{600}$ Of note, it is far more challenging to learn the environmental externalities of the production process of goods than the environmental footprint of the goods once owned.

553 ibid (emphasis added). See also ibid art 42(1) ("Those characteristics may also refer to the specific process or method of production or provision of the requested works, supplies or services or to a specific process for another stage of its life cycle even where such factors do not form part of their material substance provided that they are linked to the subject-matter of the contract and proportionate to its value and its objectives."); Recital 97. Semple, 'Glass Ceiling' (n 201) 61 ("The LtSM requirement appears in six separate provisions in the Public Sector Directive.").

554 ibid 7 ("To date, $E V N$ is the only case in which the Court has ruled that the LtSM requirement was not met.").

${ }^{555}$ Public Sector Directive (n 8) art 67(2)(a).

556 ibid art 68(1)(a).

557 ibid art 68(1)(b).

${ }^{558}$ Commission, New Rules on Public Contracts and Concessions: Simpler and More Flexible (n 548) 8-9 ("They will be allowed to evaluate bids on the basis of broader parameters: ... The production process for goods and services purchased, e.g. the employment of disadvantaged people or the use of environmentally-friendly materials, could be a determining factor in the choice of contractor. Example: a local authority could favour a firm which employs more longterm unemployed people for a public buildings maintenance contract.").

${ }^{559}$ Commission, 'Public Procurement Reform Factsheet No. 7: Green Public Procurement' (n 88) 1-2.

560 ibid. See also Public Sector Directive (n 8) Recital 93; Semple, 'Glass Ceiling' (n 201) 66 ("It may not however use its award of contract as a means of distinguishing between suppliers 
After $E V N$, the CJEU again considered the scope of the $\mathrm{LtSC}$ requirement in its influential Dutch Coffee/Max Havelaar judgment, issued during the period when the 2014 directives were under negotiation. ${ }^{561}$ The Court upheld the principle that criteria that relate to a particular means of production (e.g., organic agriculture) or distribution (e.g., fair trade purchasing terms) could be considered to be linked to the subject-matter of a contract for supply of products. ${ }^{562}$ However, as noted in Recital 97, contracting authorities cannot consider the general policies of the supplier as whole. ${ }^{563}$

This limitation removes the ability to incorporate general corporate environmental/social responsibility policies beyond the specific needs of the contracting authority. Thus, strict application of the LtSC requirement may pose problems for achieving the objectives of including environmental criteria given the complexity of supply chains and magnitude of "upstream" environmental and social impacts. ${ }^{564}$ On the other hand, abandoning or loosening the link may pose problems in terms of verification of criteria and the targeted benefits. ${ }^{565}$ Semple points to three reasons for questioning the value of a strict link to the subject-matter requirement.

The first is that it may specifically undermine the environmental or social objectives which contracting authorities wish to pursue via their procurement, many of which are endorsed at Union level. The second is that it tends to counteract attempts to reduce the burdens placed on suppliers at the pre-tender stage. The third is that it is more likely to result in market fragmentation and to impede the free movement of goods and services, as well as the efficient

who produce or supply a greater percentage of renewable energy overall, or who invest in new generation capacity - unless this in some way affects the electricity which it is purchasing. Public sector demand for renewable electricity may push prices up, due to limitations on production capacity.").

${ }^{561}$ Dutch Coffee (n 443).

${ }^{562}$ Ibid paras 89-92.

${ }^{563}$ Public Sector Directive (n 8) Recital 97 ("However, the condition of a link with the subjectmatter of the contract excludes criteria and conditions relating to general corporate policy, which cannot be considered as a factor characterising the specific process of production or provision of the purchased works, supplies or services. Contracting authorities should hence not be allowed to require tenderers to have a certain corporate social or environmental responsibility policy in place."); Semple, 'Glass Ceiling' (n 201) 62 ("Although the recitals are not in themselves binding, they do express the intention of the legislator and should inform interpretation of the directives' substantive provisions. The combined effect of Article 67(3) and Recital 97 is to emphasise that specifications, criteria and contract performance clauses must relate to the goods, services or works being purchased, and not concern matters which fall outside of the scope of the contract at hand.").

${ }^{564}$ Semple, A Practical Guide (n 179) 197-201. See also Semple, 'Glass Ceiling' (n 201) 50.

565 ibid 50. 
allocation of resources which is the ultimate aim of these freedoms, than approaches which are not specific to the subject-matter of the contract. ${ }^{566}$

The question is whether LtSC is a limiting principle in the Directive making sustainable choices less achievable, or whether corporate policies will ultimately be integrated into specific product or services. The hope is that LtSC helps sustainable outcomes in the performance of the contract directly (e.g., where a supplier reduces the carbon emissions associated with production or delivery of a product or service), or indirectly by encouraging companies to change general corporate practices. ${ }^{567}$ Would allowing consideration of general corporate policies improve private environmental governance, and ultimately improvement of specific products and services?

A goal is to ensure that contracting authorities obtain the best possible offer with efficient use of public monies and the link to the specific product/service is important. The LtSC requirement might limit discrimination from other Member States where overall corporate policies are more prevalent, ${ }^{568}$ make small- and medium-sized enterprises (SMEs) more competitive as they can create eco-friendly products but cannot compete with overall corporate environmental policies like waste management or a company eco-label, and stop any "additionality" concerns. ${ }^{569}$ This is probably correct in the short-term (e.g., large chain restaurants have better health code records than non-chains), but perhaps not in the long-term if SMEs innovate. Also, presumably contracting authorities do not include criteria in procurement decisions unless they in some way contribute to value from their perspective. ${ }^{570}$ In this way, the LtSC requirement limits the value of the product or service, and suggests that contracting authorities in the EU, like American states under the market participant exception, should have greater leeway, if not complete freedom, in making this determination.

Concerns about corporate social responsibility, from environmental stewardship to community benefits, are increasingly prevalent both within pro-

\footnotetext{
566 ibid 69.

567 ibid 51.

568 ibid 67 ("A tenderer who moves their warehouse or production facility closer to the point of consumption would therefore attain higher marks than they would otherwise - notwithstanding that this may increase their overall emissions due to longer transport routes to other customers.").

569 ibid 71 ("A better argument against loosening the link to the subject-matter requirement might be that it puts the 'additionality' of sustainable procurement measures at risk. For example, if marks can be awarded for a supplier's overall production of renewable energy instead of just that which is produced for a particular contract, can it be claimed that there is an additional positive impact from the award of the contract itself?").

570 ibid 63.
} 
curement decisions by private companies and consumption decisions by private citizens, and the idea that the public sector should be uniquely restrained from acting on such concerns in its purchasing is anomalous. ${ }^{571}$ Some these issues are addressed in the horizontal clause under Article 18(2) of the Public Sector Directive, discussed above. Removing the LtSC requirement may be a next step in helping price and efficiency take a back seat to sustainability, but getting rid the of the requirement may violate the principle of proportionality. Is it important to distinguish between supplier and the thing that is supplied? Perhaps EU procurement policy can simply make the LtSC requirement more flexible to allow inclusion of company level environmental policy, rather than remove the requirement all together. If the LtSC requirement remains as is, will third-party certifiers and eco-labels shift focus away from company policy to solely the products themselves?

\subsubsection{Eco-Labels}

The Public Sector Directive rules on labels help lift some of the burdens on contracting authorities in taking account of environmental considerations when purchasing. Contracting authorities may directly refer to eco-labels and their criteria in the procurement process, with some caveats. ${ }^{572}$ The Directive defines "label" as "any document, certificate or attestation confirming that the works, products, services, processes or procedures in question meet certain requirements." ${ }^{573}$ The rules allow public purchasers to refer to a specific label or eco-label, and their criteria, when laying down the environmental characteristics of the works, goods or services they wish to purchase. ${ }^{574}$ The rules do not allow requiring only a specific label as a product that meets the environmental criteria, though not certified with a particular label, is considered functionally equivalent. ${ }^{575}$

\footnotetext{
571 ibid 70.

${ }^{572}$ See generally Roberto Caranta, 'Labels as enablers of sustainable public procurement' 112 in Sjåfjell (n 201).

${ }^{573}$ Public Sector Directive (n 8) art. 2(1)(23). See also ibid art. 2(1)(24) (““label requirements' means the requirements to be met by the works, products, services, processes or procedures in question in order to obtain the label concerned"). See also Commission, 'Public Procurement Reform Factsheet No. 7: Green Public Procurement' (n 88) 1 (“A label is a mark/document attesting that a given product fulfils established and predefined quality conditions and requirements.").

${ }^{574}$ Public Sector Directive (n 8) art. 43(1) ("Where contracting authorities intend to purchase works, supplies or services with specific environmental, social or other characteristics they may, in the technical specifications, the award criteria or the contract performance conditions, require a specific label as means of proof that the works, services or supplies correspond to the required characteristics . . . ."); Commission, Public Procurement Reform Factsheet No. 7: Green Public Procurement (n 88) 1-2.
}

${ }^{575}$ See generally Dutch Coffee (n 443). 
Under Article 43 of the Directive, the contracting authority can seek an ecolabeled product so long as the criteria, as discussed above, are linked to the subject matter of the contract, ${ }^{576}$ based on objectively verifiable and non-discriminatory criteria, established in an open and transparent procedure in which all relevant stakeholders, accessible to all interested parties, and set by a third party over which the economic operator applying for the label cannot exercise a decisive influence. ${ }^{577}$

Interestingly, however, where an economic operator has no possibility of obtaining the specific label indicated by the contracting authority or an equivalent label, the contracting authority shall accept other appropriate means of proof that the works, supplies, or services to be provided by it will fulfill the requirements of the specific label or the specific requirements indicated by the contracting authority. ${ }^{578}$ This puts governments/public contracting entities in the unique, and perhaps challenging, position of functionally becoming certifying entities. This may increase costs and administrative burdens for contracting entities that may lack necessary expertise to make such evaluations.

A key point must be made. The Directive "stops short of enabling contracting authorities to insist on third-party certification in most circumstances, ${ }^{\prime 579}$ permitting verified self-declarations. While this may promote greater competition, ${ }^{580}$ especially where more ambitious environmental criteria are applied, one must be concerned that this may undercut investments in third-party certification. ${ }^{581}$

\footnotetext{
576 Semple, 'Glass Ceiling' (n 201) 64 (“An example of this can be seen in the new provisions regarding the use of environmental and social labels, which state that contracting authorities may only require a specific label where its requirements only concern criteria which are linked to the subject-matter of the contract. In practice, labelling schemes typically cover a range of sustainability criteria relevant to the industry in question, many of which can only be meaningfully enforced at organisation level rather than for a particular product or service. A small factory producing paper products may have to choose between a general environmental certification for its facility and specific labels for each type of paper it produces. If the LtSM requirement is interpreted strictly, contracting authorities will hesitate to refer to the more general certification scheme which may also contain requirements not linked to their specific purchase. For the small operator, this may require a higher level of investment in certification with a lower return (because it is not relevant to other customers). Importantly, it would also interfere with economic operators choosing certifications which will deliver the greatest environmental or social benefits based on their overall activities ....").

${ }^{577}$ Public Sector Directive (n 8) art. 43(1)(a)-(e). See also ibid Recital 7; Commission, 'Public Procurement Reform Factsheet No. 7: Green Public Procurement' (n 88) 1.

${ }^{578}$ Public Sector Directive (n 8) art. 43(1). See also ibid Recital 88.

${ }^{579}$ Semple, A Practical Guide (n 179) 184.

${ }^{580}$ Caranta, 'The Changes to the Public Contract Directives and the Story They Tell About How EU Law Works' (n 437) 420-21 ("So as not to limit competition too much, contracting authorities are under an obligation to accept equivalent labels and, under given conditions, alternative means of proof.").
}

${ }^{581}$ Semple, A Practical Guide (n 179) 184. 
One might lament that the EU law makers did not choose to go further down the road of imposing mandatory requirements in this respect. And indeed the European Parliament seemed ready to push more strongly economic operators to seek labels and environmental management standards certification. ${ }^{582}$

Ultimately, the data will answer this empirical inquiry on how to best use labels based on whether contracting entities are requiring technical specifications based upon labels and if operators are receiving those certifications, or instead self-declaring that they are meeting the criteria.

\subsubsection{Life-Cycle Costing}

Likely the most significant part of the 2014 Public Sector Directive is the allowable inclusion of life-cycle costing in contract award criteria in determining the lowest cost tender. Life-cycle costing will require significant methodological innovation by both contracting entities and economic operators to measure all the externalities during the course of a product's life cycle from cradle-to-grave. But, going further, these externalities will have to be monetized, and, thus, the use of the term "life-cycle costing" rather than "life-cycle analysis" or "life-cycle assessment" remains significant.

Under Article 67(1) of 2014/24/EU addressing contract award criteria, "contracting authorities shall base the award of public contracts on the most economically advantageous tender." 583 Article 67(2) states:

The most economically advantageous tender from the point of view of the contracting authority shall be identified on the basis of the price or cost, using a cost-effectiveness approach, such as life-cycle costing in accordance with Article 68, and may include the best price-quality ratio, which shall be assessed on the basis of criteria, including qualitative, environmental and/or social aspects, linked to the subject-matter of the public contract in question. Such criteria may comprise, for instance: (a) quality, including technical merit, aesthetic and functional characteristics, accessibility, design for all users, social, environmental and innovative characteristics and trading and its conditions.... 584

Since the "most economically advantageous tender" must use a "cost-effective approach" such as "life-cycle costing," economic operators must be able to monetize and contracting entities must be able to value all the costs occurring during the life cycle of a product or service, if the life-cycle approach is used. ${ }^{585}$

${ }^{582}$ Caranta, 'Labels as enablers of sustainable public procurement' (n 572) 112.

${ }^{583}$ Public Sector Directive (n 8) art. 67(1).

584 ibid art. 67(2) (emphasis added).

${ }^{585}$ Caranta, 'The Changes to the Public Contract Directives and the Story They Tell About How EU Law Works' (n 437) 424 ("True, Article 67(2) seems to indicate that life cycle costing is 
The outcome of the EU legislative process is that Directive 2014/24 both provides a working definition of life-cycle costing and lays down award criteria through which contracting authorities (and entities) may take account of externalities in their purchasing decisions. ${ }^{586}$ Under 2014/24/EU Article 2(1)(20), "life cycle" is defined as "all consecutive and/or interlinked stages, including research and development to be carried out, production, trading and its conditions, transport, use and maintenance, throughout the existence of the product or the works or the provision of the service, from raw material acquisition or generation of resources to disposal, clearance and end of service or utilization." ${ }^{587}$ Measurement of the environmental externalities of the life cycle will have to occur first, followed by monetization. Article 68 of 2014/24/EU goes further in defining life-cycle costing award criteria:

1. Life-cycle costing shall to the extent relevant cover parts or all of the following costs over the life cycle of a product, service or works: (a) costs, borne by the contracting authority or other users, such as: (i) costs relating to acquisition, (ii) costs of use, such as consumption of energy and other resources, (iii) maintenance costs, (iv) end of life costs, such as collection and recycling costs. (b) costs imputed to environmental externalities linked to the product, service or works during its life cycle, provided their monetary value can be determined and verified; such costs may include the cost of emissions of greenhouse gases and of other pollutant emissions and other climate change mitigation costs.

2. Where contracting authorities assess the costs using a lifecycle costing approach, they shall indicate in the procurement documents the data to be provided by the tenderers and the method which the contracting authority will use to determine the life-cycle costs on the basis of those data. The method used for the assessment of costs imputed to environmental externalities shall fulfil all of the following conditions: (a) it is based on objectively verifiable and non-discriminatory criteria. In particular, where it has not been established for repeated or continuous application, it shall not unduly favour or disadvantage certain economic operators; (b) it is accessible to all interested parties; (c) the data required can be provided with reasonable effort by normally diligent economic operators, including economic operators from third countries party to the GPA or other international agreements by which the Union is bound.

3. Whenever a common method for the calculation of lifecycle costs has been made mandatory by a legislative act of the Union, that common method shall be applied for the assessment of life-cycle costs. ${ }^{588}$

\footnotetext{
only one type of cost-effectiveness. However, it is difficult to think of additional hypotheses of cost-effectiveness going beyond life cycle costing plus (some aspects of) the very broad criterion referred to as best price-quality ratio.").

586 ibid 398.

587 Public Sector Directive (n 8) art. 67(2)(1)(20).

${ }^{588}$ Ibid art. 68. See also ibid Recital 96.
} 
For now, the challenges posed by life-cycle costing are left to the Member States and private innovation of life-cycle costing methodology, perhaps in combination with eco-labels and third-party certification.

In addition, environmental considerations are also allowed via the performance clause in Article 70 of the Public Sector Directive, where a specific environmental or energy parameter is required for the good or service. But without national guidance or EU legislation installing a specific LCC methodology, significant burdens may be placed on the court system. In cases where national legislation does not complement the directives with the adequate methodologies or characteristics of data to be provided by bidders, courts will have the difficult task of assessing whether the data requested by the contracting authorities were available for a diligent economic operator. ${ }^{589}$ "Interesting case law may lie ahead in this field." ${ }^{90}$ In time, a universal approach may be accepted and legislated upon as "the definition of common methodologies for life-cycle costing has significantly advanced." 591

It is clear that the Directive allows contracting authorities to evaluate bids based on the total life-cycle cost (including the carbon footprint) of goods or services; for example, a local authority wishing to purchase a school bus could favor buses which, even though they are more expensive initially, consume less fuel, require less maintenance and have a longer life span. ${ }^{592}$ Recital 97 in 2014/24/EU offers other examples: requiring manufacturing that did not involve toxic chemicals, that the purchased services are provided using energyefficient machines, or requiring waste minimization or resource efficiency. ${ }^{593}$ However, considerable complexity exists when making procurement decisions based on environmental life-cycle costs such as efficiency of newer versus existing products, embedded energy and emissions involved in production, the way in which current units will be disposed of, lifespan of new equipment, and transportation, packaging and installation of replacements. ${ }^{594}$

Where innovation will be necessary is in moving beyond the summation of costs incurred in production of a good or service to creating life-cycle costing methodologies. ${ }^{595}$ Writes Caranta:

${ }^{589}$ Dragos, 'Life-Cycle Costing for Sustainable Public Procurement in the European Union' (n 90) 132.

590 ibid.

${ }^{591}$ Public Sector Directive (n 8) Recital 95.

${ }^{592}$ Commission, New Rules on Public Contracts and Concessions: Simpler and More Flexible (n 548) 8.

${ }^{593}$ Public Sector Directive (n 8) Recital 97.

${ }^{594}$ Semple, A Practical Guide (n 179) 184.

${ }^{595}$ Caranta, 'The Changes to the Public Contract Directives and the Story They Tell About How EU Law Works' (n 437) 397 ('The most relevant innovation is possibly the codification of life cycle costing analysis or methodologies. Beside a margin of profit, the cost of any good or service is given by the sum of the costs incurred in producing the good or service at issue."). 
Public procurement practice and law were of course aware of further costs ultimately borne by the contracting authority, such as for instance running costs, cost-effectiveness, after-sales service and technical assistance. Where the uncertainties arose was in how to deal with externalities - and particularly environmental externalities such as pollution - in both the production, use and decommissioning phases of the life cycle of a good or service.$^{596}$

How will these environmental externalities be measured and valued? This question is foreshadowed in Recital 96 that declares that the life-cycle costs (e.g., research and development, production, transport, use, maintenance, disposal, environmental externalities) can be considered, "provided that they can be monetized and monitored." Can they be effectively monetized? Environmental law and policy has already shown the challenges in measuring the costs of pollution and natural resource extraction, and it remains to be seen whether institutions involved in green public procurement (e.g., countries, municipalities, businesses, third-party certifiers) can create innovative life-cycle costing methodologies (as discussed further below in Part 9).

\subsection{Summary}

As a result of the 2014 Public Sector Directive, EU Member States and contracting authorities may explicitly consider environmental considerations in procurement decisions. CJEU case law provided the foundation for the 2014 public procurement reform. The 2014 Public Sector Directive seeks to allow Member States to use their purchasing power to buy goods and services that foster market innovation, combat climate change, and improve employment, public health and social conditions. The Directive allows contracting authorities to consider environmental factors through life-cycle costing, eco-labeling criteria, and compliance with existing environmental law. EU public procurement reform has given public contracting authorities the green light to engage in sustainable procurement. This marks a major shift towards sustainability in the public procurement regime.

The 2014 Public Sector Directive contains at least four major provisions fostering green public procurement. These provisions include: (1) a horizontal clause, under Article 18, requiring that in the performance of public contracts economic operators comply with all environmental, social and labor obligations stemming from EU, international, and national law; (2) under Article 67(3), an expansive view of what is linked to the subject matter of contract in environmental criteria, allowing consideration of all points of the production

See also Commission, 'Public Procurement Reform Factsheet No. 7: Green Public Procurement' (n 88) 2 ("The new rules promote a life-cycle costing approach.").

${ }^{596}$ Caranta, 'The Changes to the Public Contract Directives and the Story They Tell About How EU Law Works' (n 437) 397. 
process; (3) allowing award criteria to refer directly to the inclusion of ecolabels; and (4) the emergence of life-cycle costing as a way to determine the true cost of a tender. Under Article 67(1) addressing contract award criteria, contracting authorities must base the award of public contracts on the most economically advantageous tender, but Article 67(2) permits the use of lifecycle costing as a basis for this approach. In particular, the development of eco-labeling requirements and life-cycle costing methodology may result in significant innovation, though potentially complex implementation. 


\section{Green Public Procurement Implementation in the EU with Sweden as a Case Study}

\subsection{Introduction}

As of 2014, the Swedish National Agency for Public Procurement Agency estimated that purchases covered by Swedish procurement laws were worth $€ 70$ billion, approximately one-fifth of Sweden's GDP. ${ }^{597}$ There is a great challenge to taking advantage of this economic power and to implementation of any green or sustainable public procurement program due to the sheer number of goods and purchasers. Within national governments there are numerous agencies making independent procurement choices, and countries contain a breathtaking number of municipal governments that have their own procurement needs and processes.

This Part 8 looks at these challenges of implementation in the EU, focusing on Sweden in particular. Sweden has the highest level of green criteria in tender offers in the EU, is considered a leader in chemical regulation and waste minimization, is the home of high-quality eco-certification labels, and has turned into a destination for business firms and leaders looking to green their supply chains. The Swedish Ministry of Finance has declared that "Sweden shall be at the forefront in green public procurement and continue to lead by example in this area." 598 Already, environmental criteria apply to how 190 Swedish government authorities conduct their public procurement. ${ }^{599}$

\footnotetext{
597 Åsa Edman and Peter Nohrstedt, 'Sweden No Socially Responsible Public Procurement without Monitoring the Contract Conditions' (2017) 3 EPPPL 352, 355.

${ }^{598}$ Government Offices of Sweden, Ministry of Finance, National Procurement Strategy $22<$ https://www.upphandlingsmyndigheten.se/globalassets/english/procurement/national_public_procurement_strategy_english_web.pdf $>$.

599 ibid (referencing the Ordinance (2009:07) on Environmental Management in Government Authorities).
} 


\subsection{Implementation of the 2014 Public Sector Directive}

\subsubsection{General Implementation Challenges}

At the national/EU Member State level, the relevant policy question is whether purchasing within centralized governments can make GPP have sufficient power to shift certain markets towards the production and consumption ecofriendly goods. Factors include the extent of existing centralization in their purchasing framework (perhaps like France and Italy), whether public purchasing has sufficient market share in some product categories, the existence of user-friendly purchasing processes and LCC methodologies, applying GPP to as many products as possible (not just recycled paper, IT, lighting and appliances as is commonplace), and applying GPP to all levels of government (local and national) and all public institutions like universities, schools, prisons, offices, and hospitals.

Directive 2014/24/EU, in pushing for more sustainable markets, required Member State implementation of the directive via national legislation by April 18, 2016. ${ }^{600}$ All EU Member States have now implemented, in some form, the 2014 Public Sector Directive. ${ }^{601}$ The 2014 Directive does not provide an overarching framework for environmental decision making as this is left to Member States. ${ }^{602}$ Thus, the Directive is not uniformly applied, and there is "good reason for studying and describing national legal systems in relation to specific issues of EU public procurement law." ${ }_{603}$ For example, prior to the still pending Brexit, the United Kingdom's Public Contracts Regulations implemented Directive 2014/24/EU. ${ }^{604}$ In doing so, the UK government's Sustainable Procurement Tool emphasized the importance of taking the life-cycle cost of items into account and promoting the Directive's sustainability goals, ${ }^{605}$ and

${ }^{600}$ Public Sector Directive (n 8) art. 90(1).
${ }^{601}$ For information on the status of implementation in the EU Member States, see National
Transposition Measures Communicated by the Member States Concerning: Directive
2014/24/EU of the European Parliament and of the Council of 26 February 2014 on public
procurement and repealing Directive 2004/18/EC Text with EEA relevance <http://eur-lex.eu-
ropa.eu/legal-content/EN/NIM/?qid=1463200444432\&uri=CELEX\%3A32014L0024>.

${ }^{602}$ Semple, A Practical Guide (n 179) 184.

${ }^{603}$ Comba, Green and Social Considerations in Public Procurement Contracts: A Comparative Approach (n 26) 299-300. See also ibid ('In other words, knowing other Member States' ways of implementation of the EU procurement Directives can help to implement them in one's own national legal system, and to implement them in a way that aims to foster the uniform application of EU law. Circulating the interpretations of the Directives provided by the national Courts and administrations is a useful tool for making their application uniform throughout the Union. This is already a challenging objective.").

604 Public Contracts Regulations 2015, SI 2015/102, 126, <http://www.legislation.gov.uk/uksi/2015/102/pdfs/uksi_20150102_en.pdf>.

605 Government UK, 'Sustainable Procurement Tools' $(2$ Sept 2014) $<$ https://www.gov.uk/guidance/sustainable-procurement-tools $>$. 
the country published information aimed at encouraging more environmentally friendly procurement. ${ }^{606}$

\subsubsection{National Implementation in Sweden}

Sweden has the highest level of green criteria in tender offers in the EU, is considered a leader in chemical regulation and waste minimization, is the home of high-quality eco-certification labels, and has turned into a destination for business firms and leaders looking to green their supply chains. Sweden also has a very centralized national government (which should help green procurement efforts), but also 290 independent municipalities with varying levels of competency in engaging in GPP and varying degrees of reliance on the Swedish National Agency for Public Procurement (SvNPA) and SKL Kommentus, a voluntary organization of Swedish municipalities that provides procurement support to the public sector.

The Swedish Ministry of Finance's "National Procurement Strategy" includes environmentally responsible public procurement with the goals of (1) creating well-formulated environmental criteria for goods and services so that GPP can act as a strong driving force for sustainable development, (2) using GPP as a strategic tool in Sweden's transition to a circular, bio-based economy in order to meet environmental objectives, and (3) using GPP to meet the Sustainable Development Goals and the 2030 Agenda.$^{607}$ The Ministry has recognized that some product categories have a disproportionate negative impact on the environment, and that environmental concerns and a life-cycle perspective should be taken into account during public procurement process. ${ }^{608}$ Of note, the Strategy states, "Even if the price for a particular public procurement becomes higher if subject to environmental criteria, the overall cost to society may be lower in the long term." ${ }^{609}$

While SvNPA, discussed in further detail below, has not designed true LCC tools, they have created total cost of ownership tools and spreadsheets that allow municipalities to calculate the monetary and environmental costs of purchase, use, replacement, and disposal of products like lighting and appliances. However, Swedish municipalities, despite the efforts by SvNPA, have found

\footnotetext{
606 The National Agency for Public Procurement, 'Requirements on Products' $<$ https://www.upphandlingsmyndigheten.se/en/sustainable-public-procurement/sustainableprocurement-criteria/imposing-environmental-requirements-the-right-way/requirements-onproducts/> accessed 29 Jul 2019; Government UK, 'Greening Government Commitment Targets' (8 Aug 2014) <https://www.gov.uk/government/publications/greening-government-commitments-targets/greening-government-commitment-targets>.

${ }^{607}$ Government Offices of Sweden, National Procurement Strategy (n 598) 22.

608 ibid.

${ }^{609}$ ibid.
} 
these tools difficult to implement and often prefer to rely on product labels or lists of approved/green products developed by third-party organizations. Sweden has also put legislation into place based upon the 2014 EU Directives in its Public Procurement Act. ${ }^{610}$ Sweden has also published information aimed at encouraging more environmentally friendly procurement. ${ }^{611}$

The former Swedish law LOU 2007:1091 was based on the old public procurement directive (2004/18/EU). The legislation allowed procuring authorities to include environmental demands in award criteria, and such authorities can consider the "lowest price" (with environmental criteria in the technical specifications) or the most economically advantageous offer, the latter being more flexible as it can include environmental factors in the award criteria (or a combination of the two).

The Swedish government first engaged in preparatory work (e.g., an inquiry report SOU 2014:15) in order to implement Directive 2014/14/EU. The Swedish inquiry report does not require mandatory use of LCC (SOU 2014:51), ${ }^{612}$ allowing continued use of the lowest price method. ${ }^{613}$ However, legislative use of the word "should" or "should when relevant" would certainly indicate that, while voluntary, GPP can and should be a powerful tool.

In 2016, the Swedish government released its official proposition for the new legislation on public procurement, followed by formally amending its national public procurement legislation. The new Swedish law (Lagen om offentig upphandling 2016:1145) has been in force since January 1, 2017. ${ }^{614}$ Thus, the Swedish legislation does not push the envelope, and environmental requirements in public procurement are not mandatory for municipalities. The new Swedish Act on Public Procurement (2016:1145) only indicates that they

\footnotetext{
610 ibid.

611 The National Agency for Public Procurement, 'Requirements on Products' $<$ https://www.upphandlingsmyndigheten.se/en/sustainable-public-procurement/sustainableprocurement-criteria/imposing-environmental-requirements-the-right-way/requirements-onproducts/> accessed 29 Jul 2019.
}

${ }^{612}$ SOU 2014:51, ch 9 pp 294-299.

${ }^{613}$ See also Caranta, 'The Changes to the Public Contract Directives and the Story They Tell About How EU Law Works' (n 437) 424 ("Beside the fact that the lowest price is still obviously an option, we have a provision collapsing together price, cost, cost-effectiveness and pricequality ratio in a way that will require much ingenuity from the practitioners and the courts to understand. A reasonable assumption seems to be that contracts may be awarded either to a) the lowest price; b) the lowest life-cycle costing, c) the best price-quality ratio, or d) a combination of the latter two.").

${ }^{614}$ For details on the Swedish implementation of the Public Sector Directive in general, see Andrea Sundstrand and Robert Ågren, 'The implementation of Directive 2014/24/EU in Sweden: a sanguine approach' in Steen Treumer and Mario Comba (eds) Modernising Public Procurement: The Approach of EU Member States (Edward Elgar 2018) 260-277. 
"should" do so, "if" the character of the procurement motivates it. ${ }^{615}$ In addition, the formulation of legal technical requirements is weak; only stating that procuring authorities "may" use environmental requirements. ${ }^{616}$ That said, SvNPA has made two important points in promoting GPP. First, "[c]ontracting authorities have substantial leeway in imposing far-reaching requirements on what goods or services are being contracted....," and, second, these environmental requirements "can go beyond those stipulated in EU harmonised legislation." ${ }^{617}$

Consistent with the national agency's approach and assessment, there are stronger green procurement rules for authorities at the national level in Sweden. According to the Förordning (a lower legal status than law created by the national government, not by Parliament, that has application to Swedish authorities until the next government possibly changes them), the authorities "shall" take the environment into account when such an adjustment of the procurement is possible. ${ }^{618}$

Why is there such a great policy difference between municipal and national level authorities (including all the universities)? This is a national policy question. Perhaps the national government does not want to burden municipalities with the difficulties embedded in green procurement if made mandatory. Municipalities already find it hard to follow procurement rules without the additional burden of special policy goals such as protecting the environment. Or perhaps it is because the national level authorities make procurements for larger monetary values and, thus, have more environmental impact through their procurement power.

Regardless of whether LCC methodology is required or recommended, it is not clear who would come up with the appropriate methodology. With so many municipalities in Sweden, if all have their own LCC methodology, companies would not know how to respond. Hence, Sweden created the National Agency for Public Procurement (SvNPA) in 2015 to develop sustainable procurement tools.

${ }^{615}$ Environment in the new Swedish Act on Public Procurement (2016:1145), 4 kap $3 \S$ (noting that a procuring authority should take environmental, social and workers' rights aspects into account at public procurements, if the character of the procurement motivates this) (emphasis added).

616 ibid.

617 The National Agency for Public Procurement, 'Sustainable public procurement' $<$ https://www.upphandlingsmyndigheten.se/en/sustainable-public-procurement/> accessed 17 Oct 2019.

${ }^{618}$ Förordning (2009:907) om miljöledning i statliga myndigheter, $13 \S$ (This Ordinance states, "The environmental management system shall amount to that the authority adjusts their procurements to environmental issues when such an adjustment is possible."). 


\subsection{The Role of the Swedish National Procurement Agency}

The Swedish Environmental Management Council (SEMCO) was created in 2003 to begin the process of producing a tool for calculating life-cycle costs aimed at public procurers, where it is possible to include environmentally related costs. By 2006, Swedish government agencies were purchasing "green" cars, and Sweden created an action plan for GPP in 2007. In 2015, the Swedish National Agency for Public Procurement (SvNPA) was created to develop GPP technical criteria for all public institutions, in hopes that agencies can cut and paste criteria into their tender documents, as well as develop LCC tools (though, to date, these have just been total cost of ownership tools rather than true cost accounting).

SvNPA develops methods and tools to make the procurement process more effective, and hosts a database with sustainability criteria for different product areas (e.g., energy efficient appliances and office equipment) and locations (e.g., schools). Two major tools it employs are (1) sustainability criteria for tender offers, and (2) total cost of ownership tools (though they call them "LCC" tools).

SvNPA has developed sustainability criteria and technical specifications that can be used in tender offers the areas of: (1) IT and Telecom; (2) Building and property; (3) Cleaning and chemicals; (4) Vehicles and transport; (5) Office and textiles; (6) Food; (7) Nursing and care; and in achieving a national goal of (8) Toxic-free pre-schools. ${ }^{619}$

SvNPA has also developed a general "LCC" tool, and specialized calculators are available for professional kitchens (fridges and freezers), ${ }^{620}$ indoor ${ }^{621}$

\footnotetext{
${ }^{619}$ The National Agency for Public Procurement, 'Sustainability Criteria' $<$ http://www.upphandlingsmyndigheten.se/en/sustainable-public-procurement/sustainable-procurement-criteria/> accessed 29 Jul 2019.

${ }^{620}$ The National Agency for Public Procurement, 'Life Cycle Cost Calculation - Professional Refrigerators and Freezers' $<$ http://www.upphandlingsmyndigheten.se/en/sustainable-publicprocurement/sustainable-procurement-criteria/building-and-property/professionalkitchen/professional-refrigerators-and-freezers/life-cycle-cost-calculation---professional-refrigerators-and-freezers/> accessed 29 Jul 2019.

621 The National Agency for Public Procurement, 'Indoor Lighting' <http://www.upphandlingsmyndigheten.se/en/sustainable-public-procurement/sustainable-procurement-criteria/building-and-property/indoor-lighting/light-sources-and-luminaires/lcc-lifecycle-cost-calculation-for-light-sources/> accessed 29 Jul 2019.
} 
and outdoor lighting, ${ }^{622}$ household appliances, ${ }^{623}$ and private cars. ${ }^{624}$ These calculators are in Microsoft Excel and require businesses/tenderers to supply and input the relevant information, something that has proven to be a challenge for local municipalities. These calculators started with indoor and outdoor lighting and vehicles, and exist for appliances and vending machines. No calculators yet exist for food.

While SvNPA claims to have created "LCC tools," they actually evaluate the total cost of ownership, measuring environmental and energy outputs arising after procurement. They do not consider full cradle-to-grave environmental externalities. That said, the sustainability criteria, which do take into account environmental externalities in production processes through technical criteria found in eco-labels, combined with the SvNPA "LCC tools" get closer to life-cycle assessment (LCA) (see Part 9) and somewhat closer to true LCC. Getting to true LCC in terms of identifying all environmental externalities and monetizing them, as well as costing out how products are used by individual users, will be a significant challenge.

Thus, SvNPA and all EU Members states are in a learning stage, trying to figure out supply chain details in a whole host of product areas. In Sweden, $20 \%$ of its GDP comes from public procurement, with municipalities accounting for $50 \%$ of all advertised procurements. But progress is clearly being made. As seen in Table 2 below, GPP is improving over time.

Table 2: GPP Progress in the Public Sector in Sweden

\begin{tabular}{lll}
\hline Year & $\begin{array}{l}\text { Government authorities always or } \\
\text { usually stipulate environmental re- } \\
\text { quirements when purchasing }\end{array}$ & $\begin{array}{l}\text { Government authorities have procure- } \\
\text { ment policies that include environmen- } \\
\text { tal considerations in purchasing }\end{array}$ \\
\hline 2004 & $60 \%$ & $41 \%$ \\
2007 & $57 \%$ & $78 \%$ \\
2009 & $57 \%$ & $82 \%$ \\
2013 & $70 \%$ & $84 \%$ \\
\hline
\end{tabular}

Source: SvNPA (2016)

Decision-makers responsible for public procurement often are not equipped with the proper information or technical knowledge to appropriately apply

\footnotetext{
622 The National Agency for Public Procurement, 'The Lighting System's Life Cycle Cost' $<$ http://www.upphandlingsmyndigheten.se/en/sustainable-public-procurement/sustainableprocurement-criteria/building-and-property/outdoor-lighting/lighting-design/the-lighting-systems-life-cycle-cost-lcc/> accessed 29 Jul 2019.

${ }^{623}$ The National Agency for Public Procurement, 'LCC' <http://www.upphandlingsmyndigheten.se/en/sustainable-public-procurement/sustainable-procurement-criteria/building-andproperty/household-appliances/washing-machines/lcc/> accessed 29 Jul 2019.

${ }^{624}$ The National Agency for Public Procurement, 'Life Cycle Costing (LCC)' <http://www.upphandlingsmyndigheten.se/en/sustainable-public-procurement/sustainable-procurement-criteria/vehicles-and-transport/vehicles/private-cars/life-cycle-costing-lcc/> accessed 29 Jul 2019.
} 
life-cycle costing. ${ }^{625}$ Systems and indicators must be tailored for local contexts and simplified such that non-expert users can apply tools, in order to "extend procurement beyond green purchasing and create more sustainable food systems and better public health nutrition." ${ }^{26}$ Testa et al. considered the effectiveness of two methods to aid decision makers in the implementation of GPP: toolkits or supporting information; and direct training sessions. ${ }^{627}$ The study found that "[a]wareness and knowledge of GPP techniques and procedures appear to be the greatest driver for developing this approach and, symmetrically, the most relevant barrier for non-adopters," but both guidelines and trainings can help decision makers overcome this barrier. ${ }^{628}$

\subsection{The Role of the EU in Standardizing Implementation}

Eventually, the EU may come up with a common EU LCC methodology (or perhaps a common methodology for each product/service category) and it will be added to the Directive Annex, but it is unclear when this might occur, whether Member States would be required to use it, and, as discussed below, what this methodology might be. Recital 96 states:

Common methodologies should be developed at Union level for the calculation of life-cycle costs for specific categories of supplies or services. Where such common methodologies are developed, their use should be made compulsory.

Furthermore, the feasibility of establishing a common methodology on social life cycle costing should be examined, taking into account existing methodologies such as the Guidelines for Social Life Cycle Assessment of Products adopted within the framework of the United Nations Environment Programme. ${ }^{629}$

Of course, while EU environmental law is a floor and not a ceiling, and does "not prevent . . . more stringent measures" in terms of environmental protection (Article 193 TFEU), Sweden cannot simply declare mandatory increased environmental standards for all products as trade is a harmonized area of law. ${ }^{630}$ This, ultimately, is the main rationale for EU- or nation-wide LCC

\footnotetext{
${ }^{625}$ Testa (n 69) 1894.

${ }^{626}$ Smith (n 94) 255.

${ }^{627}$ Testa (n 69) 1894.

628 ibid 1897-98.

${ }^{629}$ Public Sector Directive (n 8) Recital 96.

${ }^{630}$ Peter Oliver, 'Book Review: EU Environmental Law and the Internal Market, by Nicolas de Sadeleer (2014)' (2014) 51 CML Rev 1873, 1874 ('The question here is: can a Member State
} 
standards to be incorporated into the public procurement process. The efforts in Europe have also given rise to several international green procurement networks and projects to aid member states in implementing green procurement, such as the Public Procurement Network, Procura Campaign, Buy Smart project, UNEP SPP Implementation Guidelines, and Procurement of Innovation (PPI) Platform. ${ }^{631}$

Despite initial progress in GPP, there remains the question of who should have the larger role in fostering GPP - the EU or the Member States. For example, the Directive "treads a thin line between empowering contracting authorities to develop [LCC] methodologies and worrying that this could be done to favour certain economic operators" ${ }^{632}$ Given the costs of creating and implementing LCC methodologies, the obvious next step is for the EU to develop uniform LCC methodologies. At this point, the Directive relies on "the traditional idea of the directive as an instrument binding as to the result to be achieved but leaving to the national authorities the choice of form and methods. ${ }^{633}$ However, the EU has developed GPP technical environmental criteria in a number of product groups to foster the inclusion of green requirements in public tender documents. ${ }^{634}$

A step further would be for Member States or the EU to require contracting authorities to purchase sustainable goods and services (or provide incentives to do so). Member States are beginning to take this step. Slovakia is requiring that "social aspects" be considered in some contracts, ${ }^{635}$ though environmental

impose its own environmental standards on other Member States by means of such restrictions? For instance, can they prohibit imports of goods manufactured according to highly polluting methods of production? And can they ban exports of goods on the grounds that they will not be handled in an environmentally friendly way? In principle, such "altruism" is not justified under Article 36, although Advocate General Jacobs in Werner recognized an exception where human life is at stake. On a closer examination of the case law, de Sadeleer maintains that there is a case for saying that environmental protection is a further exception, at least as regards concerns common to all Member States: in those circumstances, the justification is not "altruistic" at all. There is considerable force in this suggestion.").

631 Commission, 'Networks and Initiatives' <http://ec.europa.eu/environment/gpp/initiatives_en.htm> accessed 6 Aug 2016; Commission, 'Buy Smart+ Green Procurement in Europe (BUY SMART+)' <https://ec.europa.eu/energy/intelligent/projects/en/projects/buy-smart-0> accessed 29 Jul 2019 (project co-funded by the Intelligent Energy Europe Programme of the European Union, to establish helpdesks for green procurement in various countries to set guidelines and assist in implementing green procurement running from 2012-2014); Eur Parliament, 'Green Public Procurement and the EU Action Plan for the Circular Economy' (n 202) 7.

${ }^{632}$ Caranta, 'The Changes to the Public Contract Directives and the Story They Tell About How EU Law Works' (n 437) 457.

633 ibid 458.

${ }^{634}$ EU GPP Criteria, <https://ec.europa.eu/environment/gpp/eu_gpp_criteria_en.htm>.

${ }^{635}$ Act No. 112/2018 on social economy and social enterprises (Slovakia), amending Act No. 343/2015 Coll. on Public Procurement (Slovakia Public Procurement Act). 
considerations are not included. Social aspects include decent, fair and satisfactory working conditions, inclusion of disadvantaged, vulnerable or excluded persons and groups of people in social relations and simplifying their access to the labor market. ${ }^{636}$ In the Netherlands, the Dutch Public Procurement Act of 2012, passed prior to the 2014 EU Public Sector Directive, obligates Dutch contracting authorities to "achieve as much societal value as possible for their public resources." " ${ }^{377}$ However, there is considerable debate as to what aspects of sustainability "societal value" may or may not include, thus leaving contracting authorities the challenging task of defining the term. ${ }^{638}$

There are implementation benefits to EU-wide standards, or, perhaps (relying on American notions of sovereignty and the "laboratory of democracy"), creating EU incentives for a race to the top for GPP. Unfortunately, the European Union seems opposed to mandatory requirements or quotas in respect to environmental procurement. But will the lack of mandatory obligations in the Directive stifle any innovation? Ultimately, mandatory GPP reform will need to come from the EU or its Member States to create market demand and define life-cycle costing methodologies for all product areas (or at least the most environmentally costly ones). Prior to that, however, the future of green public procurement lies with public and private implementing institutions and firms that will develop standards for eco-labels and life-cycle costing.

\subsection{The Challenges of Local Green Public Procurement Implementation}

Fostering the success of local implementation is especially salient in Sweden given the sheer number of municipalities and that local authorities are responsible for the majority of procurements in the country. ${ }^{639}$ To ensure compliance with the environmental conditions of the contract, municipalities must engage in monitoring and contract management. ${ }^{640}$ The ability of individual communities to engage in such oversight as well as pick sustainable goods in the first place is limited by the few tools, time, and resources available at the local level. Thus, municipalities can enlist the help of a central purchasing authority. SKLKommentusInköpscentral (SKI) is a Swedish central purchasing body responsible for 290 municipalities, 20 county councils and a majority of their

\footnotetext{
636 ibid.

${ }^{637}$ Article 1.4(2) Aanbestedingswet 2012 (Netherlands).

${ }^{638}$ See Willem A Janssen and Gerrieke Bouwman, 'Legislating societal value into Dutch public procurement law: from symbolism to substance?' (2019) Public Procurement L Rev.

${ }^{639}$ Edman, 'Sweden No Socially Responsible Public Procurement without Monitoring the Contract Conditions' (n 597) 355.
}

${ }^{640}$ See ibid 352, 354. 
1500 companies. ${ }^{641}$ SKI has concluded that, due to the complexity and opaqueness of supply chains, monitoring of compliance with sustainability criteria is essential. ${ }^{642}$ This can be accomplished through greater cooperation and use of shared resources among contracting authorities (e.g., shared audits) and starting a dialogue with suppliers about the monitoring process. ${ }^{643}$

\subsection{Summary}

EU Member States face many challenges in taking advantage of the economic power of public procurement to foster environmental interests. This remains true even in Sweden, a leader in GPP. In order for GPP to have sufficient power to shift certain markets towards the production and consumption of ecofriendly goods, there must be sufficient centralization in their purchasing frameworks, sufficient public purchasing market share in some product categories, the existence of user-friendly purchasing processes and LCC methodologies, and broad-based use of GPP to all levels of government and all public institutions.

Directive 2014/24/EU, in pushing for more sustainable markets, required Member State implementation of the directive via national legislation by April 18, 2016. The 2014 Directive does not provide an overarching framework for environmental decision making as this is left to Member States. In 2016, the Swedish government released its official proposition for the new legislation on public procurement, followed by formally amending its national public procurement legislation. The new Swedish law implementing the 2014 Directive has been in force since January 1, 2017. The Swedish legislation does not push the envelope, and environmental requirements in public procurement are not mandatory for municipalities. That said, contracting authorities have substantial leeway in imposing far-reaching environmental requirements on contracted for goods and services.

The Swedish National Agency for Public Procurement (SvNPA) is the national agency responsible for promoting increased environmental considerations in public procurement and has developed environmental and social criteria in different product categories for use by contracting authorities. Despite these efforts, informational and technological burdens exist for government entities to fully implement GPP, especially absent standardized life cycle costing tools created at the EU level.

\footnotetext{
${ }^{641}$ ibid 355.

642 ibid 357.

643 ibid.
} 


\section{The Future of Green Procurement: Life- Cycle Costing and Eco-Labels}

\subsection{Introduction}

There has been a shift away from traditional "command and control" regulatory systems towards market mechanisms and other neoliberal regulatory approaches. In particular, as result of the decline of public environmental law, there is greater reliance on private environmental governance, where industry changes their actions to be more environmentally friendly in response to shifting corporate norms, and on public regulations that can influence the market like informational tools and public procurement. Green public procurement provides a compelling example of this transition, though in a middle space involving both public and private entities, as it invokes both product eco-labeling and evaluation of product supply chains, whereby public institutions will influence changes in industry by demanding certain label criteria and better sustainability within products' life cycles.

Through these tools, GPP seeks to increase demand for environmentally friendly goods, and create innovation in the marketplace. ${ }^{644}$ This Part 9 addresses two key components of the Public Sector Directive that will play an outsized role in achieving these goals - the development of life-cycle costing methodologies (9.2) and the role of eco-labeling and their criteria (9.3) as requirements for products to meet these standards in order to be purchased. How can such requirements lead to new markets and re-define the share of ecofriendly goods in some markets, especially when these reforms are voluntary? ${ }^{645}$ While evaluating "success" will prove challenging, one can look at

\footnotetext{
${ }^{644}$ Caranta, 'The Changes to the Public Contract Directives and the Story They Tell About How EU Law Works' (n 437) 394 ("Public procurement is said to play a key role in this by a) improving framework conditions for business to innovate, making full use of demand-side policy; b) supporting the shift towards a resource-efficient and low-carbon economy, for instance "by encouraging wider use of green public procurement", and finally c) improving the business environment, especially for innovative SMEs."). See also Public Sector Directive (n 8) Recital 47 (mentioning "eco-innovation").

${ }^{645}$ Commission, 'Revision of Public Procurement Directives - Frequently Asked Questions, Memo/14/20' (15 Jan 2014) ("The new rules will contribute to the implementation of the Europe 2020 Strategy for a greener, more social, innovative and inclusive economy. It should be stressed that no 'what to buy' obligations are provided for. Contracting authorities will decide if they want to take advantage of the new possibilities put at their disposal.").
} 
trends in the marketplace in terms of the use of eco-labels and evolution of life-cycle methodologies that will be adopted in the green public procurement process. This Part 9 provides suggestions for how these can lead to greater GPP effectiveness.

If green public procurement is to be an effective policy instrument, "the new rules should encourage public purchasers to implement environmental policies, [and t]hus, public authorities will be able to base their decision on the best life cycle cost of the goods offered." ${ }^{646}$ Green criteria can be included in multiple sections of public tender offers, ${ }^{647}$ though the "most common means of implementing environmental objectives into regulated procurement procedures appears to be via technical specifications." ${ }^{\circ 48}$ It is in these technical specifications that allow for consideration of production processes; for example, that electricity be produced from renewable sources or food produced using organic methods. ${ }^{649}$ Tender award criteria may include "externalities linked to consumption (e.g., bus pollution); externalities linked to production (e.g., renewable electricity); life-cycle costing (acquisition, use, maintenance, and disposal; it can again include externalities)." ${ }^{500}$ Environmental considerations are also allowed via the performance clause in Article 70 of the Public Sector Directive.

What is the difference between award criteria and technical specifications in the context of consideration of environmental factors? First, technical specifications are minimum mandatory requirements that must be applied to all tenderers, so they should be used when the environmental characteristics are essential for the contract and what the market can deliver is relatively known. ${ }^{651}$ Award criteria allow for distinguishing tenders based on environmental performance where the minimum or maximum levels of such performance are not known in advance. ${ }^{652}$ Second, authorities are obligated to verify that tenders comply with their requirements, while award criteria are not subject to quite the same degree of regulation. ${ }^{653}$ Thus, "award criteria may be more appropriate for addressing environmental considerations where the most effective means of delivering and verifying the desired outcome is not known in advance of publishing tender documents." ${ }^{654}$

\footnotetext{
${ }^{646}$ Dragos, 'Sustainable Public Procurement in the EU: Experiences and Prospects' (n 90) 313.

${ }^{647}$ See Semple, A Practical Guide (n 179) 183 tbl.7.3.

648 ibid 177 (stating green criteria technical specifications is most common).

${ }^{649}$ Dragos, 'Sustainable Public Procurement in the EU: Experiences and Prospects' (n 90) 317.

650 ibid 318.

${ }^{651}$ Semple, A Practical Guide (n 179) 188.

652 ibid.

653 ibid.

654 ibid.
} 
Eventually, as noted in Recital 96 of the Public Sector Directive, ${ }^{655}$ the EU may devise a common EU LCC method and it will be added to the Directive Annex, but it is unclear if or when this might occur. Alternatively, will a global standard for LCC methodology be established and by whom (government entities or a consortium of private industry)? This Part 9 considers how life-cycle costing and eco-labels are put into practice by current public institutions (i.e., contracting authorities) and private firms, as well as non-contracting government entities and non-profits, in particular focusing on existing life-cycle costing methodologies and trends in eco-labels. For example, efforts in Europe have given rise to several green procurement networks and projects to aid Member States in implementing green procurement, such as the Public Procurement Network, the Procura Campaign, and the Buy Smart project, in addition to the efforts of the European Commission. ${ }^{656}$ And some countries, like Sweden, are developing LCC tools for the procurement process. And private companies are coordinating to green their supply chains.

This Part 9 considers, in an effort to inform about the most effective practices, the evolution and development of eco-labels and life-cycle costing methodologies, and looks at how firms have developed LCC methodologies to calculate, and ultimately monetize, the cradle-to-grave environmental externalities of food products. One might predict that a common LCC methodology will be created in the EU though partnerships between the public and private sector in a market-by-market context. Private industry will be the dominant player in the U.S. in creating any LCC methodology given the lack of public sector interest in sustainable public procurement. Less certain, the EU could modify its legislation to allow specific third-party certified eco-labels to be required in the procurement process, especially as more eco-labels use LCA and LCC methodologies. This would result in a merger of eco-labeling and LCC evaluations.

\footnotetext{
${ }^{655}$ Public Sector Directive (n 8) Recital 96 ("Common methodologies should be developed at Union level for the calculation of life-cycle costs for specific categories of supplies or services. Where such common methodologies are developed, their use should be made compulsory. Furthermore, the feasibility of establishing a common methodology on social life cycle costing should be examined, taking into account existing methodologies such as the Guidelines for Social Life Cycle Assessment of Products adopted within the framework of the United Nations Environment Programme.”).

656 Commission, 'Networks and Initiatives' <http://ec.europa.eu/environment/gpp/initiatives_en.htm> accessed 6 Aug 2016; Commission, 'Buy Smart+ Green Procurement in Europe (BUY SMART+)' <https://ec.europa.eu/energy/intelligent/projects/en/projects/buy-smart-0> accessed 29 Jul 2019.
} 


\subsection{Life-Cycle Costing and Impact Valuation}

\subsubsection{Life-Cycle Costing and the 2014 Public Sector Directive}

Purchase price reflects only a narrow range of product information. Prices fail to incorporate indirect supply chain costs (environmental and social externalities) and benefits (generated eco-system services). Life-cycle costing is designed to fill this gap by evaluating the costs and benefits of a product throughout its entire life cycle, though methodologies remain in their infancy. ${ }^{657} \mathrm{LCC}$ builds on existing life-cycle assessment tools that assess environmental impacts associated with all the stages of a product's life from "cradle-to-grave" (including raw material extraction, production, processing, transportation and acquisition, use, maintenance, and ultimate product disposal) ${ }^{658}$ by translating these impacts into a single metric - monetary cost.

Article 68 of the 2014 Public Sector Directive allows contracting authorities to take a life-cycle costing approach when determining the costs in the procurement process. Under EU procurement rules, a contract can be awarded based on lowest price or most economically advantageous tender. This means that contracting authorities or economic entities, or perhaps both, can assess the environmental externalities of a product over all phases of its life cycle and, significantly, be able to monetize those costs so as to be able to effectively compare the bids of different economic entities. As seen in Figure 1 below, consideration of monetized environmental externalities can change the determination of what is the lowest priced good.

\footnotetext{
${ }^{657}$ Dragos, 'Sustainable Public Procurement in the EU: Experiences and Prospects' (n 90) 324.

${ }^{658}$ See National Risk Management Research Laboratory, Office of Research and Development, US Environmental Protection Agency, Life Cycle Assessment: Principles and Practice, EPA/600/R-06/060 (May 2006) (EPA, Life Cycle Assessment: Principles and Practice) ("Life cycle assessment is a 'cradle-to-grave' approach for assessing industrial systems.")
} 


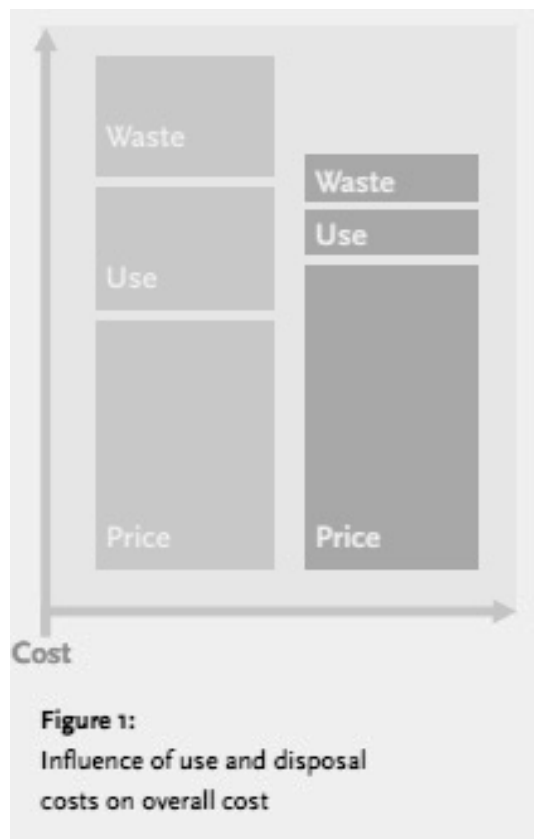

Figure 1: Example of cost difference when considering environmental externalities Source: ICLEA - Local Governments for Sustainability, The Procura+ Manual: A Guide to Cost-Effective Sustainable Public Procurement (2nd edn, 2007) 33 fig.1.

This Part 9.2 defines LCC, considers what LCC methodologies might be used, building on life-cycle assessment principles, and notes the challenges that LCC entails. For example, how does one monetize pollution and other environmental externalities of production? Environmental law policy has shown the challenges in measuring the costs of pollution and natural resource extraction. While the idea of LCA is well developed, firms are beginning to determine how to cost out all stages of a product's life cycle.

\subsubsection{What is Life-Cycle Costing?}

"The absolute novelty of the 2014 Directives regards the reference to the concept of life cycle costing." 659 Purchase price alone does not reflect the financial and non-financial gains that are offered by environmentally and socially preferable assets as they accumulate during their operations and use stages, and LCC is a tool that evaluates the costs of an asset throughout its life cycle. ${ }^{660}$

${ }^{659}$ Dragos, 'Sustainable Public Procurement in the EU: Experiences and Prospects' (n 90) 323. ${ }^{660}$ ibid 324. See also Dragos, 'Life-cycle costing for sustainable public procurement in the European Union' (n 90) 114. 
While life-cycle assessment is well known and assesses environmental impacts associated with all the stages of a product's life from "cradle-tograve," ${ }^{661}$ this is different for developing a monetary cost to these impacts.

Life cycle assessment (LCA) is a scientific, structured and comprehensive method that is internationally standardized in ISO 14040 and 14044. For practitioners of LCA, ISO 14044 details the requirements for conducting an LCA that addresses the environmental aspects and potential environmental impacts (e.g., use of resources and the environmental consequences of releases) throughout a product's life cycle from raw material acquisition through production, use, end-of-life treatment, recycling and final disposal. ${ }^{662}$ There are four phases in an LCA study: (a) the goal and scope definition phase; (b) the inventory analysis phase; (c) the impact assessment phase; and (d) improvement analysis; but there is no mention of costing. ${ }^{663}$ The International Reference Life Cycle Data System (ILCD) Handbook further specifies the broader provisions of the ISO 14040 and 14044 standards on environmental LCA. ${ }^{664}$

LCA quantifies resources consumed and emissions, as well as the environmental and health impacts and resource depletion issues that are associated with any specific goods or services, covering climate change, summer smog, toxicity, human cancer effects, and material and energy resource depletion. ${ }^{665}$ "Crucially, it allows for direct comparison of products, technologies and so on based on the quantitative functional performance of the analysed alternatives." ${ }^{666}$ LCA is increasingly being used in a market context in communication of industry to business customers, often through published environmental product declarations. ${ }^{667}$ (Note that in the public procurement context, economic entities will be the ones delivering this information to contracting authorities.)

${ }^{661}$ EPA, Life Cycle Assessment: Principles and Practice (n 658) 1.

${ }^{662}$ International Organization for Standardization 14044, Environmental Management - Life Cycle Assessment - Requirements and Guidelines.

${ }^{663}$ EPA, Life Cycle Assessment: Principles and Practice (n 658) iv ("It presents the four basic stages of conducting an LCA: goal and scope definition, inventory analysis, impact assessment, and improvement analysis. The major stages in an LCA study are raw material acquisition, materials manufacture, production, use/reuse/maintenance, and waste management.”).

${ }^{664}$ Commission, 'JRC Conference Reports, The International Reference Life Cycle Date System (ILCD) Handbook' (2012) $7<$ http://eplca.jrc.ec.europa.eu/uploads/JRC-Reference-Report-ILCD-Handbook-Towards-more-sustainable-production-and-consumption-for-a-re-

source-efficient-Europe.pdf $>$. See also Greenhouse Gas Protocol, World Resources Institute \& World Business Council for Sustainable Development 'Product Life Cycle Accounting and Reporting Standards' (2011) <http://www.ghgprotocol.org/sites/default/files/ghgp/standards/Product-Life-Cycle-Accounting-Reporting-Standard_041613.pdf>.

${ }^{665}$ Commission, 'JRC Conference Reports, The International Reference Life Cycle Date System (ILCD) Handbook’ (n 664) 8.

666 ibid.

667 ibid 16. 
LCA relies on five principles: (1) bringing a wide range of environmental problems into an integrated assessment framework; (2) capturing these problems in a scientific and quantitative manner; (3) allowing environmental pressures and impact potentials to be related to any defined system, such as a particular type of goods, a service, a company, a technology strategy, a country, etc.; (4) integrating the resource use and emissions over the entire life cycle of the analyzed system, from the extraction of natural resources through material processing, manufacturing, distribution and use, up to recycling/energy valorization and the disposal of any remaining waste; and (5) facilitating comparisons of the environmental performance of different systems/options on an equal basis and helps to identify areas for improvement. ${ }^{668}$

Environmental LCA is "structurally open" to growing into the full sustainability assessment that is LCC, where cost is integrated. ${ }^{669}$ As noted by the European Commission in 2012, an integrated, authoritative approach for such an integrated life-cycle sustainability assessment still needs to be developed. ${ }^{670}$ In other words, an authoritative LCC methodology is the next step.

In the context of sustainable public procurement, the use of LCC is a very important element in the effort to shift the paradigm of public procurement beyond the confinement of using solely the purchase price of a good or service. ${ }^{671}$

Under the 2014 EU procurement rules a contract must be awarded based on the most economically advantageous tender (MEAT). . . Purchase price, however, is just one of the cost elements in the whole process of purchasing, owning and disposing. Life-cycle costing (LCC) means considering all the costs that will be incurred during the lifetime of the product, work or service: Purchase price and all associated costs (delivery, installation, insurance, etc.); Operating costs, including energy, fuel and water use, spares, and maintenance; End-of-life costs (such as decommissioning or disposal) or residual value (i.e. revenue from sale of product). ${ }^{672}$

A movement towards LCC is important since the purchase price alone does not reflect the financial and non-financial gains that are offered by environmentally preferable assets as they accumulate during their operations and use stages. ${ }^{673}$

\footnotetext{
668 ibid 17.

${ }^{669}$ ibid 20.

670 ibid.

${ }^{671}$ Dragos, 'Sustainable Public Procurement in the EU: Experiences and Prospects' (n 90) 324.

${ }^{672}$ Commission, 'Life-Cycle Costing' <http://ec.europa.eu/environment/gpp/lcc.htm> accessed 18 Apr 2018.

${ }^{673}$ Dacian Dragos and Bogdana Neamtu, 'Sustainable Public Procurement: Life Cycle Costing (LCC) in the New EU Directive Proposal' (2013) 1 EPPPL 19, 20.
} 
While a dominant LCC methodology does not yet exist, differing approaches (often proprietary) are issued in a number of sectors. LCC has proved to be feasible in the following markets: office and server IT equipment, vehicles, indoor and outdoor lighting, fuel and furniture, services such as electricity, transport, waste handling, catering beverages, and works such as construction of new buildings or refurbishment of existing buildings, railways, roads. ${ }^{674}$ Moderate applicability has been experienced for paper and food catering, couriers and postal services, as well as landscaping. ${ }^{675}$

\subsubsection{Life-Cycle Costing Methodologies}

An environmental LCC methodology takes into account the main internal environmental cost categories plus external environmental costs. Relying on the LCA framework, LCC considers costs borne by one or more actors who are connected to the product's life cycle, indirectly and directly, extending both upstream and downstream in the product's lifespan, occurring within the "decision relevant future. ${ }^{.676}$ These actors might be suppliers, manufacturers, users, consumers, or end-of-life actors. ${ }^{677}$ Figure 2 displays the conceptual framework of environmental life-cycle costing (E-LCC).

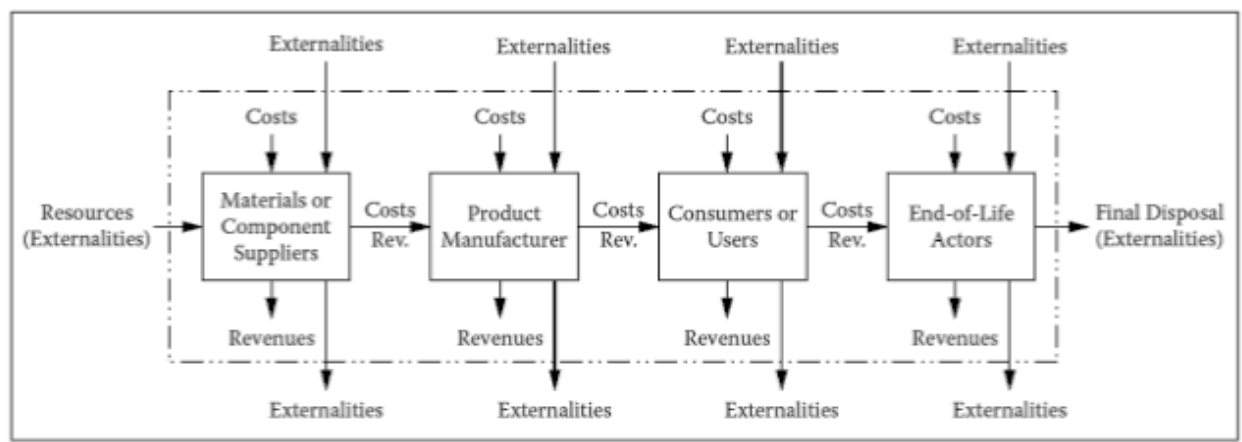

Economic system $=$ Boundaries of LCC

Social and natural system:

Boundaries of social and environmental assessment

Figure 2: Conceptual framework of environmental life-cycle costing

Source: Andreas Ciroth and others, Environmental Life Cycle Costing xxix (David Hunkeler and others (eds) 2008).

\footnotetext{
${ }^{674}$ Dragos, 'Sustainable Public Procurement in the EU: Experiences and Prospects' (n 90) 332.

675 ibid.

${ }^{676}$ Katherine Fiedler, Steven Lord and Jason J Czarnezki, 'Life Cycle Costing and Food Systems: Concepts, Trends, and Challenges of Impact Valuation' (2018) 8 Michigan J of Administrative and Environmental L 1 (citing Andreas Ciroth and others, Environmental Life Cycle Costing 1, 4 (David Hunkeler and others (eds) 2008)).
}

${ }^{677}$ Ciroth (n 676) 1, 4. 
To be introduced into an "accounting" LCC process, environmental costs must be expressed in monetary terms. In other words, environmental costs would be quantified and monetized so they can be considered as an additional cost input in a LCC analysis.

An argument in favor of environmental LCC is that assessment methods such as LCA are often viewed as obstacles to short-term business development. ${ }^{678}$ A methodology that provides a sound combination of both the environmental and economic performance of a product can help guide technological development and managerial decisions in a rational direction, identifying long-term win-win situations, and optimizing trade-offs between the environmental economic considerations. ${ }^{679}$

A case study of organic versus conventional extra-virgin olive oil illustrates the need for LCC and the need to account for external costs.

If one does not consider the external costs, the organic oil has a higher cost profile that is due to its lower agricultural yields. However, when external costs and less tangible, hidden, and indirect costs are included, this results in the organic oil having a lower total cost compared to the conventional oil. ${ }^{680}$

LCC, especially if it is to consider environmental factors, is information intensive, requiring data on costs of the complex interaction between a product and the environment from cradle-to-grave. As stated, this includes cost data on initial investment, operation, maintenance and end-of-life disposal expenses, as well as the financial value of environmental externalities (both costs and benefits) ${ }^{681}$ This means the inclusion of basic costs like delivery, installation, and insurance as well. ${ }^{62}$ This also includes measuring the external costs of the global warming contribution associated with emissions of different greenhouse gases, calculating the cost of every gram of pollution that leads to ocean acidification and eutrophication, and valuing the use of every square foot or meter of law. ${ }^{683}$

Environmental costs that might be considered in a life-cycle costing analysis for a product include, but are not limited to: air pollution, biodiversity loss, climate change, deforestation, greenhouse gas emissions, land use, soil erosion, waste, and water pollution. Some of these costs overlap with social

\footnotetext{
678 ibid 7.

679 ibid.

${ }^{680}$ ibid 120.

${ }^{681}$ Dragos, 'Sustainable Public Procurement in the EU: Experiences and Prospects' (n 90) 325.

${ }^{682}$ Commission, Buying Green! A Handbook on Green Public Procurement (n 520) 57, 60.

${ }^{683}$ Dragos, 'Sustainable Public Procurement in the EU: Experiences and Prospects' (n 90) 325.
} 
and health costs, and vice versa. ${ }^{684}$ Data may not be readily available for analyses of products and systems, or for certain categories of externalities. "If all needed data are not available, then scenario development, forecasting, or other estimation methods may have to be employed." ${ }_{685}$

MIPS (Material Input Per Service Units) assess product life-cycle impacts, and the total material input of a product system (development through manufacturing through delivery) should be measured per these units for effective results (to determine the most economically advantageous offer). ${ }^{686}$ The question is: what tools and methodologies can economic entities (or contracting authorities) use in doing this cost accounting and valuing the environmental impacts listed above along the supply chain?

Due to implementation costs, it is unlikely that all individual contracting authorities (e.g., local governments) will develop their own LCC methodologies for businesses to use when bidding on government contracts. The dominant and/or required methodologies will likely come from large public entities like the EU, national governments or particularly large cities. Large non-profits, third-party certifiers and for-profit sustainability auditors, as well as private for-profit businesses, certainly will also develop their own methodologies. These private LCC methodologies may become dominant in countries like the U.S. where public environmental initiatives are lacking. The challenge, however, in public use of these tools is that many of the methods remain private and proprietary. Private firms engage in LCC but the data is not publicly available, resulting in a lack of LCC data available to consumers as well. And to the extent that private business drives LCC methods, and thus perhaps standards in the future, one worries about the development of SMEs. In addition, a divergence of LCC methodologies may inhibit standardization efforts.

\subsubsection{Life-Cycle Costing Efforts}

Full application of life-cycle costing by industry is limited - however, industry has recognized the importance of valuing environmental and social externalities and comparing alternatives. ${ }^{687}$ Industry is acting in response to opportunities and risks presented by dependencies on natural capital (and, therefore, pressure from shareholders and investors), changing demand of consumers,

\footnotetext{
${ }^{684}$ Food Tank, The Real Cost of Food: Examining the Social, Environmental, and Health Impacts of Producing Food (2015) 13.

${ }^{685}$ Ciroth (n 676) 13.

${ }^{686}$ Ekroos, 'EC Legislation on Public Procurement and Sustainable Development' (n 80) 425.

${ }^{687}$ See Fiedler (n 676).
} 
and regulatory influence. ${ }^{688} \mathrm{~A}$ study conducted by RobecoSAM found that of 184 companies across industries, 80 percent reported that they measured and valued their impacts, but upon further analysis, only 25 percent actually did so. ${ }^{689}$ Sixty-five percent of the companies that undertook impact valuations were monetizing value, perhaps indicating a certain need for this functionality. ${ }^{690}$

Some firms have implemented basic frameworks that aim to accomplish the goals of more robust life-cycle costing techniques, yet they perhaps do not employ the full methodologies of monetizing all costs and benefits of the life cycle. ${ }^{691}$ For example, Nestlé's Creating Shared Value performance index represents an introductory life-cycle costing of their product lines as a whole, from which a true life-cycle costing might be developed. ${ }^{692}$

In the end, the dominant LCC methodology for the EU, its Member States, and municipalities in the EU, is expected to come from the European Commission, which to be effectively accomplished requires the input of private industry. However, the EU, under its Product Environmental Footprint (PEF) program, has moved quite slowly in its efforts to achieve such a goal. Absent strong public governance, a very plausible alternative, however, is an LCC methodology developed by an industry-funded consortium of academics, government policymakers, civil society and sustainable professionals within the businesses themselves. Industry feels the rise of private environmental governance and response to the reality of institutional isomorphism, whereby institutions and consumers are pressured to conform to others in their preferences for environmentally friendly goods and sustainable business practices. ${ }^{693}$

In the U.S., any standardized LCC methodology may be more likely to be birthed in the private sector due to the political limits in fostering environmental initiatives. However, the EU began this process in 2011 with the attempt to define LCC, recognizing the need to determine the cost of natural resources (e.g., water, energy), even if their market price is undervalued, foreseeing the

688 ibid (citing True Price, 'The Business Case for True Pricing' (2015) <http://trueprice.org/wp-content/uploads/2015/02/True-Price-Report-The-Business-Case-for-True-Pricing.pdf $>$ ).

689 ibid (citing Rashila Kerai, Impact: What's it Worth?, RobecoSAM 6 (2017) <https://yearbook.robecosam.com/articles/impact-whats-it-worth/>.

690 ibid 7.

${ }^{691}$ Fiedler (n 676).

692 ibid (citing Nestlé, 'Key Performance Indicators' <http://www.nestle.com/csv/performance/kpi-summary> (last visited 1 Feb 2017); Nestlé, 'Nestlé in Society: Creating Shared Value and Meeting Our Commitments' (2015) 5-6 <http://storage.nestle.com/nestle-societyfull-2015/index.html\#>.

${ }^{693}$ See Czarnezki, 'The Neoliberal Turn in Environmental Regulation' (n 4). 
challenge in pricing environmental externalities, and recognizing that effective LCC must consider product lifespan, discount rate, and data availability and reliability.

Perhaps the best existing methodological baselines on which we may see further improvement are the National Capital Protocol, a standardized framework for business to identify, measure and value direct and indirect impacts on natural capital ${ }^{694}$; the ISO 14007 and 14008 standards on valuing environmental costs and benefits ${ }^{695}$; and insights from the March 2017 White Paper "Operationalizing Impact Valuation: Experiences and Recommendations by Participants of the Impact Valuation Roundtable". ${ }^{696}$ ISO 20400 also provides sustainable procurement guidance, but not certification.

The EU has developed some environmental externality costing models as part of existing directives and through LCC calculating tools. ${ }^{697}$ For example, the 2009 Clean Vehicles Directive costs externalities as its "model allocates a monetary value to several types of emission - carbon dioxide $\left(\mathrm{CO}_{2}\right)$, nitrous oxide $\left(\mathrm{NO}_{\mathrm{x}}\right)$, non-methane hydrocarbons (NMHC) and particulate matter." 998 This suggests the likelihood, and importance, of a sector-by-sector analysis costing environmental externalities in the course of sustainable public procurement. There are already EU environmental obligations in the specific sectors of office IT equipment, road transport vehicles, and buildings. However, while the revised 2019 Clean Vehicles Directive makes note of the importance of LCC, it does not provide any mandatory methodology. Recital 20 states:

Life-cycle costing is an important tool for contracting authorities and contracting entities to cover energy and environmental costs during the life-cycle of a vehicle, including the cost of greenhouse gas emissions and other pollutant emissions on the basis of a relevant methodology to determine their monetary value. Given the scarce use of the methodology for the calculation of operational lifetime costs under Directive 2009/33/EC and the information provided

\footnotetext{
${ }^{694}$ Natural Capital Coalition, 'Natural Capital Protocol' (2016) <http://naturalcapitalcoalition.org/protocol/>.

${ }^{695}$ International Organization for Standardization 14007, Environmental Management: Determining Environmental Costs and Benefits - Guidance; International Organization for Standardization 14008, Monetary Valuation of Environmental Impacts and Related Environmental Aspects.

${ }^{696}$ Impact Valuation Roundtable, 'Operationalizing Impact Valuation: Experiences and Recommendations by Participants of the Impact Valuation Roundtable, White Paper' (2017) $<$ https://www.basf.com/documents/corp/en/sustainability/management-and-instruments/quantifying-sustainability/we-create-value/IVR_Impact_Valuation_White_Paper_2017.pdf $>$.

${ }^{697}$ Dragos, 'Sustainable Public Procurement: Life Cycle Costing (LCC) in the New EU Directive Proposal' (n 673) 21 (examples of where ELCC is already incorporated into EU Directives include the since amended Clean Vehicles Directive (2009/33/EC), and Regulation $(106 / 2008)$ where central government authorities are required to purchase only office IT equipment meeting certain minimum energy-efficiency levels).
}

${ }^{698}$ Commission, Buying Green! A Handbook on Green Public Procurement (n 520) 59. 
by contracting authorities and contracting entities on the use of own methodologies tailored to their specific circumstances and needs, no mandatory methodology should be required to be used, but contracting authorities and contracting entities should be able to choose any life-cycle costing methodology in order to support their procurement processes on the basis of the most economically advantageous tender ('MEAT') criteria as described in Article 67 of Directive 2014/24/EU and Article 82 of Directive 2014/25/EU, taking into account cost-effectiveness over the lifetime of the vehicle, as well as environmental and social aspects. ${ }^{699}$

The European Commission has developed the SMART-SPP LCC and Emissions Online Tool to compare bids. The tool has been developed to help public authorities calculate the life-cycle costs and emissions (CO2, NOx, SO2, $\mathrm{NMHC}$, and PM) of different products, work and services to assist in procurement decision-making. ${ }^{700}$ With this tool in the background, the EC is developing a formal LCC calculation tool to facilitate the use of the LCC approach amongst public procurers in accordance with Article 68 of the Public Sector Directive 2014/24/EU. Reports suggest it will focus on specific product categories such as Office IT Equipment, Lighting (Indoor Lighting), White Goods, Vending Machines and Medical Electrical Equipment. The EU may rely on the European Commission Joint Research Center's Product Environmental Footprint (PEF) as the technical conceptual framework for EU green public procurement. ${ }^{701}$ There have been several projects (SENSE EU project, and the European Commission initiatives for Product Environmental Footprint and Organisation Environmental Footprint) looking at generating tools that can calculate LCA, and an attempt to standardize the many LCAs in existence, which businesses might use as calculators to make 'accepted' sustainable procurement arguments.

The future trajectory of LCC methodology faces many barriers in development and implementation by government entities. A survey found that $83 \%$ of purchasing professionals considered themselves ill equipped to deliver sustainability through procurement. ${ }^{702}$ To achieve success in GPP, a number of conditions will likely have to be met:

\footnotetext{
${ }^{699}$ Directive 2019/1161 of the European Parliament and of the Council of 20 June 2019, amending Directive 2009/33/EC on the promotion of clean and energy-efficient road transport vehicles.

${ }^{700}$ LCC Public Procurement Tool, 'Calculating Your Real Costs' <http://tool.smart-spp.eu/> 17 Apr 2018.

${ }^{701}$ Commission, Development of a weighting approach for the Environmental Footprint (JRC Technical Reports 2018).

702 Dragos, 'Sustainable Public Procurement: Life Cycle Costing (LCC) in the New EU Directive Proposal' (n 673) 29.
} 
- Increased reliance on technology to compute life-cycle costs. ${ }^{703}$

- Agreement on what environmental indicators to include and price in the LCC process (e.g., climate change, ozone layer, air quality, waste generation, freshwater quality, freshwater resources, forest resources, fish resources, energy resources and biodiversity).$^{704}$

- Access to reliable data and agreement on consideration of co-benefits, discounting and unquantifiable benefits such as lowered risks, avoided environmental damage, avoided clean-up costs. ${ }^{705}$

- Limit geographic discrimination under the guise of GPP as LCC can include environmental externalities resulting from transportation, creating the potential for discrimination against suppliers further from consumption site via monetization of emissions. ${ }^{706}$

- Agreement on pricing as it will be a challenge to assess the costing of the whole life cycle of products, services and supplies - especially due to fluctuations in commodity and electricity prices. ${ }^{707}$

- Agreement on the price of carbon and greenhouse gas emissions.

Ultimately, of course, "[o]ne problem that is arising when considering sustainable public procurement is that procuring goods, services or works on the basis of life cycle costing may mean paying more in the beginning," ${ }^{08}$ until demand, and thus scale, increases. In addition, forecasting costs and benefits with an acceptable degree of certainty is very challenging. ${ }^{709}$

In order to solve the challenges of LCC in the GPP context, the EU might consider making GPP mandatory. ${ }^{710}$ Effective GPP also requires LCC tools that are easily implemented, with life-cycle data incorporation into eco-labels, and standardization in LCC methods and data transfer. A proposed path to greater GPP effectiveness might look like this:

\footnotetext{
${ }^{703}$ Semple, A Practical Guide (n 179) 204 ("Likewise, the computation of life-cycle costs, including the application of common EU methodologies and insertion of costs attributed to environmental externalities, is an area with obvious potential for enhanced used of technology.").

${ }^{704}$ Dragos, 'Sustainable Public Procurement: Life Cycle Costing (LCC) in the New EU Directive Proposal' (n 673) 20-21.

705 ibid 27-28.

${ }^{706}$ Semple, A Practical Guide (n 179) 192.

${ }^{707}$ Dragos, 'Sustainable Public Procurement: Life Cycle Costing (LCC) in the New EU Directive Proposal' (n 673) 29.

708 ibid 28.

709 ibid 27-28.

${ }^{710}$ See Willem A Janssen and Jason J Czarnezki, Mandatory Requirements in the EU Public Procurement Directives: Proposals for Regulatory Reform (forthcoming 2020).
} 
First, national governments of the EU Member States and American States in the U.S. federal system create mandatory GPP legislation in order to lower the costs and information burdens of green procurement.

Second, more effective and user-friendly procedures, tools, and technologies are created for municipalities to engage in effective GPP.

Third, eco-labeling is fully embraced in the GPP project to make purchasing decisions easier. As discussed below, eco-labeling will begin to incorporate LCC methodologies, and the EU Public Sector Directive may need revision to allow for third-party certified eco-labeling requirements rather than just as evidence of meeting technical criteria. In the U.S., absent more aggressive public GPP regulation, LCC data will most likely be found in private ecolabels.

Finally, creation of standards is the long-term goal. Standards are needed in life-cycle costing methodology. The EU could become a leader in developing LCC tools so there is not a patchwork quilt of local or private tools that favor local companies or entrenched industry actors that would lead to discrimination or lack of innovation. Equally importantly are standards in data transfer. One of the main problems associated with costing is that life-cycle assessment tends to be based on aggregate, generic modeling. To cost properly requires knowing exactly the flow of commodities, the cost of processing, and the cost of consuming. This requires improved technology, standardized data gathering and transfer techniques, and consistent valuation methodology, with the challenge being how to cost out future benefits based on abating current environmental costs.

\subsection{Trends in Eco-Labels}

\subsubsection{Introduction to Eco-Labels and Procurement}

Given the proliferation and growing importance of eco-labels, ${ }^{711}$ and the technical criteria that they convey, life-cycle costing will likely be integrated into eco-label criteria, making certain eco-labels in demand for public procurement purposes. This will be especially true in the U.S. where life-cycle costing data will have to be incorporated into labels rather than as part of a large-scale GPP implementation plan created by public law. In this way, U.S. GPP will be more "neoliberal" than efforts in the EU.

In the public procurement process, eco-labels can help illustrate technical specifications in order to define the characteristics of the goods or services that are being purchased, as well as check compliance with these requirements

\footnotetext{
${ }^{711}$ Cf Barnard, European Union Law (n 110) 1 (noting the growing importance of eco-labels, suggesting that eco-labels should be regulated at EU level given its single market, and exemplifying the ubiquity of eco-labels by starting the book with eco-labels as an example).
} 
by accepting the label as one means of proof of compliance with the technical specifications. ${ }^{712}$

One also wonders why eco-labels were not a larger part of EU procurement reform given the EU Eco-label criteria for many product groups created by Commission Decisions adopted under powers conferred by European Parliament and Council Regulation 66/2010. ${ }^{.13}$ Regardless, economic entities in need of LCC to pursue tender offers may rely on third-party methodology to do this work, ${ }^{714}$ even if the EU defines the methodology. This may lead public authorities to require specific eco-labels (rather than only their technical criteria). ${ }^{715}$

As a form of information regulation, eco-labels contain many different types of information that come from many different sources. In terms of a taxonomy of eco-labels, labels have content (i.e., the type of information that the label contains) and require validation (by an entity that determines what information is conveyed and assesses its validity). ${ }^{716}$

\subsubsection{Eco-Label Content}

Eco-label content can be sorted into two sets of categories. First, a label can convey environmental information that is positive (a claim that the product is environmentally friendly in some way), negative (a warning that the product is risky to human health or the environment), or neutral (information that may only be meaningful relative to a scale). Warning labels often also include instructions for safe use. Second, the label conveys information either about the product itself or about the process by which the product was made. In the LCC context, neutral labels are likely to be the norm, possibly combined with positive claims.

Neutral labels offer information that is not in itself positive or negative. For instance, environmental product declarations (EPDs) are "industry-created

712 Commission, Buying Green! A Handbook on Green Public Procurement (n 520) 37, 40; Semple, A Practical Guide (n 179) 189.

${ }^{713}$ Barnard (n 110) 2.

${ }^{714}$ US General Services Administration and US Dept of Energy, Verification Guide for Federal Purchasers of Sustainable Products (unknown date) (noting preference of third-party certification).

715 Though in the context of the CE mark, for example, a label is already accepted as in compliance with a technical standard.

716 Jason J Czarnezki and Margot Pollans, 'Eco-labeling' in Oxford Handbook on Comparative Environmental Law (Oxford University Press 2018). See also Czarnezki, 'Creating Order Amidst Food Eco-Label Chaos' (n 11). This thesis relies on both of these papers for the "EcoLabel Content" and "Label Sources" parts of this section. 
statements containing a variety of information about the composition and environmental characteristics of a product based on life-cycle assessment." This approach would inform consumers about a wide range of life-cycle environmental concerns associated with the product such as water usage, chemicals used, pollution and carbon emissions, and waste disposal. Unlike an ecolabel seal, an EPD alone would disclose information "in a neutral way that enables consumer evaluation but that does not seek to judge the environmental characteristics of a product." ${ }^{\prime 18}$

Positive claims seek to induce consumers to choose the eco-friendly item over an equivalent, but non-eco-friendly, item. As eco-friendly products are often more expensive to produce, the label provides a mechanism for sellers to increase the price and capture the consumer's willingness to pay more for the actual or perceived benefits associated with the environmental claim. Positive claims might relate directly to consumer health or might communicate an environmental characteristic of the product.

The process/product distinction is also key to understanding eco-label content. Process claims convey information about the conditions of manufacture, including, but not limited to, chemical and fossil fuel inputs, ingredient sourcing practices, water and energy use during processing, distribution methods, and environmental by-products of processing. A process claim does not, however, convey any information about the product itself, which may be functionally and chemically identical to a product produced under different circumstances. Positive processing claims often relate to sustainable sourcing, and, thus, will be the backbone of LCC eco-labels.

LCC eco-labels will also necessarily strive to be entire process claims, rather than partial process claims, attempting to incorporate a product's entire life cycle into a single metric. All processing and product attributes from cradle-to-grave factor into the life-cycle analysis. Requiring a large number of variables, this process is extremely data intensive. In the global market, products reach consumers at the end of long, complex supply chains, that include raw material extraction, processing, packaging, and distribution that may happen in many places around the world by a number of different private companies.

\footnotetext{
${ }^{717}$ Nancy J King and Brian J King, 'Creating Incentives for Sustainable Buildings: A Comparative Law Approach Featuring the United States and the European Union' (2005) 23 Virginia Environmental LJ 397, n.232 (citing Commission, 'Summary of Discussions at the 2nd Integrated Product Policy Expert Workshop: Environmental Product Declarations (ISO 14025 Technical Report)' (2001) $2<$ http://ec.europa.eu/environment/ipp/pdf/epd.pdf $>$.

718 ibid.
} 


\subsubsection{Label Sources}

First-party labels are governed only by the producing company. Although all labels rely on private companies to share information about product content and production processes, some label schemes rely on private third-party certification. Third-party labels mitigate some of these concerns by imposing uniform publicly available standards, yet accountability concerns remain. The third-party certification industry has grown dramatically in recent years. Both first-party and third-party schemes are entirely voluntary.

Some labels are publicly governed. These include both publicly mandated information disclosures and voluntary labels with government oversight of label standards and a public verification process.

Private voluntary label schemes can either be self-declared or thirty-party certified. Self-declared, or first-party labels include a broad range of claims including "sustainable," "environmentally-friendly," and "natural." Some are grounded in self-created and published standards. "A self-declaration environmental claim is one that is made without independent third-party certification by manufacturers, importers, distributors, retailers, or anyone else likely to benefit from such a claim." $" 119$

The proliferation of self-declared eco-labeling schemes, and resulting consumer confusion and skepticism, had led many manufacturers and retailers to turn to independent, third-party entities to certify that environmental product claims are valid. ${ }^{720}$ Third-party labels, also called Type I labels by the ISO 14020 series, require independent certification entities that develop and implement standards for use of certifier-owned trademarked labels.

\footnotetext{
719 Richard B Stewart, 'A New Generation of Environmental Regulation?' (2001) 29 Capital U L Rev 21, 136 n.449. See also Atsuko Okubo, 'Environmental Labeling Programs and the GATT/WTO Regime' (1999) 11 Georgetown International Environmental L Rev 599, 608 ("The other subcategory of the voluntary, private-sponsored labeling schemes is based on selfdeclaration claims, or first-party claims. A self-declaration environmental claim is an environmental claim that is made, without independent third-party certification, by manufacturers, importers, distributors, retailers, or anyone else likely to benefit from such a claim. Such a declaration can take such forms as statement symbols, package labels and advertising.") (citation omitted).

${ }^{720}$ Elliot B Staffin, 'Trade Barrier or Trade Boon?: A Critical Evaluation of Environmental Labeling and Its Role in the "Greening" of World Trade' (1996) 21 Columbia J Environmental L 205, 216-17 (citing US Environmental Protection Agency, Status Report on the Use of Environmental Labels Worldwide (1993) 6-7); Avi Gesser, 'Canada's Environmental Choice Program: A Model for a "Trade-Friendly" Eco-Labeling Scheme' (1998) 39 Harvard International LJ 501, 512 (discussing environmental labeling in Canada, and stating: "Understandably, consumers are skeptical about the truthfulness of environmental claims made by the manufacturers themselves. As a result, unregulated first-party environmental labeling programs provide little assistance for many environmentally conscious consumers. This is not only because producers may make misleading claims about the environmental friendliness of their products, but also because they may lack the resources and expertise to properly evaluate their goods.”).
} 
Government sponsored label programs include both voluntary and mandatory labels. In voluntary programs, certification standards are publicly developed, and producers can choose whether or not to apply for certification. In mandatory programs, producers are required to include particular information on the product label.

Many label schemes also seek to make entire process claims by evaluating a product's whole life cycle. For example, the European Union's voluntary flower logo program indicates products that are more environmentally friendly than conventional products based on a life-cycle ecological assessment. ${ }^{721}$ The European Union uses five administrative layers to implement its eco-label scheme, and has developed product groups and ecological criteria to harmonize environmental labeling in its member countries. ${ }^{722}$ The eco-label can be affixed to those products that meet established product group criteria for the entire life cycle of the product.

The flower logo, however, has met only limited success since the label is still is taking time to gather traction with consumers. ${ }^{723}$ The European Union flower logo program is an ambitious project since its goal is to introduce one eco-label for the outset, intended eventually to replace all national labels within the European Union. ${ }^{724}$

In addition, individual European countries have led in the creation of ecolabels with the Nordic Council Program (the Nordic Swan logo of Norway, Sweden, and Finland) and Germany's Blue Angel Program. ${ }^{725}$ In Germany's Blue Angel Program, an environmental label jury comprised of representatives from environmental groups, science organizations, consumer associations, industry, trade unions, and the media reviews life-cycle reports to determine if the "Unweltzeichen" ("environmental label") is appropriate. ${ }^{726}$ It must be again noted that such "national" labels can be referred in the procurement process under the 2014 Public Sector Director so long as products and services meeting the equivalent standards without the labels are considered.

Germany's program, the oldest eco-labeling program in Europe, is perhaps the most successful as German consumers make frequent and continuous use

${ }^{721}$ Commission, EU Eco-label <http://ec.europa.eu/environment/ecolabel/> accessed $18 \mathrm{Apr}$ 2018.

722 Julian Morris, Green Goods?: Consumers, Product Labels and the Environment (IEA 1997) 42.

${ }^{723}$ Renate Gertz, 'Eco-labelling — a case for deregulation?' (2005) 4 Law, Probability and Risk, 127, 128, https://doi.org/10.1093/lpr/mgi010.

724 ibid.

${ }^{725}$ Other public and private eco-labels include Green Seal, Sweden's Bra Miljöval (Good Environmental Choice), Canada's EcoLogo, Japan's Eco-Mark. Also see the ISO 14024 standards for eco-labelling, $<$ http://www.iso.org/iso/catalogue_detail.htm? csnumber=23145>.

${ }^{726}$ Surya P Subedi, 'Balancing International Trade with Environmental Protection; International Legal Aspects of Eco-Labels' (1999) 25 Brooklyn J of International L 373, 378. 
of the eco-label as a means of obtaining product information and shopping accordingly. ${ }^{727}$ Given the success of eco-labeling in Germany and Scandinavia, one concern about any state-sponsored eco-label in the United States is whether it could only achieve a degree of success in a geographic location with a relatively high environmental consciousness among its population. ${ }^{728}$

The public sector has begun to promote eco-label standardization, and recognized the movement towards life-cycle data within labels. The United Nations Office for Project Services (UNOPS) defines an eco-label as "a label which identifies overall environmental preference of a product or service based on life-cycle considerations." ${ }^{729}$ In fact the suggestion is that the term "eco-label" itself should only be used for "[o]nly independent and reliable labels that consider the life-cycle impact of products and services . . . even if this term is commonly used in a broad and not always correct way." "730

UNOPS recognizes the utility of eco-labels in the GPP process. Environmental labels can bring a valuable contribution to the implementation of sustainable procurement, and be used in different ways by procurement practitioners to include green criteria in their tenders, without having to be experts in environmental issues. ${ }^{731}$ Eco-labels can be used for translation of environmental criteria of the labels into technical specifications, for verification of compliance with technical specifications, benchmark offers at the award stage, and for use for single issues and performance labels as a progressive approach. ${ }^{732}$

However, procurement practitioners in the EU, unlike in the U.S., cannot require suppliers to have their products or services registered under a specific eco-labelling scheme. Such barriers may ultimately breakdown due to the link between eco-labels and life-cycle costing methods as a result of the need to generate complex data and provide it to consumers in a useable form.

\subsubsection{Integrating Life-Cycle Costing into Eco-Label Criteria}

LCC data may be incorporated into eco-label criteria. Already, eco-labels are used to provide verification of technical criteria. For example, the Swedish National Procurement Agency's basic technical criteria can be verified by listed EU Eco-label and Nordic Swan eco-label standards that need to be met if displaying that label. The natural evolution will be for eco-labels to verify

\footnotetext{
${ }^{727}$ Gertz (n 723) 136.

${ }^{728}$ See ibid.

${ }^{729}$ United Nations Office for Project Services (UNOPS), A Guide to Environmental Labels for Procurement Practitioners of the United Nations System (2009).

730 ibid 10.

731 ibid 13.

732 ibid.
} 
measures of life-cycle costing. These eco-labels will have to (1) determine what LCC factors to incorporate, (2) develop product categories by which to compare product performance, and (3) make the label impactful.

According to ISO 14024, "[t] he objective of reducing environmental impacts and not merely transferring impacts across media or stages of the product life cycle is best served by considering the whole product life cycle when setting product environmental criteria." ${ }^{\prime 33}$ LCC methods help "expose the hidden costs of ownership that are too often neglected in favour of the investment costs." ${ }^{\prime} 34$ These hidden costs include energy and water consumption, extraction of resources, manufacturing, distribution, use and disposal. ${ }^{735}$

Of course, the elephant in the room is valuation. How does one cost out or put a value or dollar amount on these environmental externalities such as extraction of raw materials and biodiversity loss, let alone price carbon? This question has moved in the direction of natural capital accounting, which is currently too coarse to use to understand individual businesses and products, but represents the most developed thinking on economic valuation. ${ }^{736}$

Once a standardized LCC methodology exists with accompanying monetary values for environmental externalities, product categories must be developed in order to effectively compare product performance. In order to create product categories, one needs to consider the nature of the market (e.g., size of market, demand for good), nature of suppliers in the market, environmental impacts of the products, and scope of the product categories, in terms of equivalence and fitness of use comparable products. ${ }^{737}$ Then, in order to compare products within a group, products must be evaluated based on differentiation of environmental impacts along their life cycles among the products within the category. ${ }^{738}$

Once the LCC data is known (a significant challenge) and products assessed within categories, LCC information must be conveyed via an informational label in a manner that is impactful. Another challenge for eco-labels is in determining how to best convey information to consumers in a manner that will effectively shift buying preferences.

\footnotetext{
${ }^{733}$ International Organization for Standardization 14024, Environmental Labels and Declarations - Type I Environmental Labelling - Principles and Procedures.

${ }^{734}$ UNOPS, A Guide to Environmental Labels for Procurement Practitioners of the United Nations System (n 729) 19.

${ }_{735}$ ibid 19-20; International Organization for Standardization 14024, Environmental Labels and Declarations - Type I Environmental Labelling - Principles and Procedures.

736 United Nations Food and Agriculture Organization, 'Natural Capital Accounting' $<$ http://www.fao.org/nr/sustainability/natural-capital/en/> accessed 18 Apr 2018.

${ }^{737}$ International Organization for Standardization 14024, Environmental Labels and Declarations - Type I Environmental Labelling - Principles and Procedures § 6.3.1.

738 ibid § 6.4.2.2.
} 
Eco-labels require a good quality assurance scheme, which would benefit from governmental ownership of the label, and a successful marketing program. Centralized government eco-labels are more effective than numerous private ones. "Alignment with the EU Ecolabel or national eco-labels has been part of the process, contributing to the ability of suppliers to demonstrate that products or services meet the criteria developed and facilitating the verification process for authorities. ${ }^{, 739}$ Private labels can be successful if they are well known with long-standing tradition and space in the market (e.g., Blue Angel of Germany, KRAV in Sweden, the Nordic Swan eco-label), and simple, clear, obvious and transparent seal-of-approval logos and labels have generally shaped consumer behavior more than the complex information-disclosure labels. Despite the efforts of Green Seal in the U.S., it is not nearly as well known as, for example, the government issued USDA Organic label.

Eco-labels incorporating LCC will provide greater ease in the green public procurement context. ${ }^{740}$ In order for LCC to be an effective tool going forward, it must be integrated into the eco-labeling process by both industry and public law, and national governments will need to require labels or develop environmental product declaration systems. This will require a standardized process where business can supply data and a ramp up in technology where RadioFrequency Identification (RFID) systems track materials along the supply chain with data incorporated into QR codes and Smartlabels to be read by smartphones.

LCC eco-labels are the future of GPP as they reduce the information and verification burden on municipal purchasers. Explicitly allowing third-party certified eco-labels to be required as a criterion in a tender offer in the EU (and not having to consider "equivalent" criteria) may also reduce litigation that freezes the procurement process.

\subsection{Summary}

As a result of the decline of public environmental law, there is greater reliance on private environmental governance where industry changes their actions to be more environmentally friendly in response to shifting corporate norms and on softer public regulations that can influence the market like informational tools and public procurement. Green public procurement provides a compelling example of this transition, though in a middle space involving both public

\footnotetext{
${ }^{739}$ Semple, A Practical Guide (n 179) 203.

${ }^{740}$ See UNOPS, A Guide to Environmental Labels for Procurement Practitioners of the United Nations System (n 729) 22 ("Choosing to base your procurement on an ecolabel - that covers several product and service categories, offers a complete impact assessment over the life cycle and guarantees the impartiality of the scheme - is an assurance of the quality and reliability of the criteria.")
} 
and private entities, as it invokes both product eco-labeling and evaluation of product supply chains, whereby public institutions will influence changes in industry by demanding certain label criteria and better sustainability within products' life cycles.

Through these tools, GPP seeks to increase demand for environmentally friendly goods, and create innovation in the marketplace. Two key components of the 2014 Public Sector Directive that will place an outsized role in achieving these goals are the development of life-cycle costing methodologies and the role of eco-labeling and their criteria, both as requirements for products to meet these standards in order to be purchased.

The 2014 Public Sector Directive suggests that the EU hopes to come up with a common EU LCC method, though the 2019 revision to the Clean Vehicles Directive suggests that this may not be forthcoming. As a result, a diffuse network of public institutions and private firms are taking the lead in putting life-cycle costing methodologies and eco-labels into practice. Due to the increased reliance on third-party certifiers, eco-labels may incorporate LCC evaluations. 


\section{Conclusion}

The aim of this thesis is to consider the space, implementation, and value of environmental requirements in public procurement, and to what extent environmental law and green public procurement (GPP) can influence legal norms and policies promoting internal market harmonization and free market completion in the U.S. and EU. Put more succinctly, the aim is to determine the space for GPP in the U.S. and EU.

This thesis engages two specific research questions in evaluating GPP; the first related to comparative law and the second related to policy implementation. First, what can be learned about the space for GPP from comparing the U.S. and EU legal frameworks and implementation rules, specifically considering the American market participant exception to the commerce clause and the 2014 Public Sector Directive? Second, what tools are employed when engaged in GPP? In other words, what are the best tools and methods available to engage in GPP if there is the legal space?

This thesis concludes that both U.S. and EU law, through very different means, provide for sufficient space to engage in GPP, though the challenge is in figuring out how to exist in and the extent of this space, and that life-cycle costing methodologies and eco-labels will play a key role in the future of GPP.

In both the United States and European Union, can GPP be effectively used to promote environmental interests while creating new innovative markets through the use of eco-labels and life-cycle costing? Perhaps so, if the two jurisdictions can learn from each other. The U.S. legal system can be helpful to the EU in designing its GPP program in terms of suggesting opportunities for creativity and flexibility. And ultimately the EU GPP program, its perhaps forthcoming life-cycle costing methodology, and the common eco-label technical criteria it uses can be a model for U.S., and global, implementation. This thesis comes to a number of additional conclusions.

First, despite any shortcoming or limitations in GPP legislation, they are substantially offset by the value of making it clear to contracting authorities that they can pursue green public procurement. For progressive American states and EU Member States alike, legislation should be pursued that make clear that monetary costs are not the only factor to be considered when purchasing goods and services. Ironically, American states, while less sovereign than EU Member States vis-à-vis their institutions of higher law (American federal law versus EU law), may actually have more sovereignty in public 
procurement decisions given the EU's strong interest in internal market harmonization and free trade.

Second, green public procurement, especially in the EU given the 2014 Public Sector Directive, can lead to product innovation and improved measurement tools in evaluating environmental externalities within supply chains due to the broad economic power and scope of public procurement, as well as market demand for environmentally friendly products. Innovation will arise in third-party certification labeling and life-cycle costing, and new innovative/efficient industries and business practices can develop in response. While it is not clear in what market sector innovation will occur most rapidly, industry consortiums are already developing true cost accounting tools and figuring out how to value natural capital. ${ }^{741}$ One may also see significant technological innovation to help track products and their externalities along the supply chain.

Third, there is great uncertainty regarding the future of a standardized LCC methodology. As suggested by Recital 96 of the 2014 Public Sector Directive ${ }^{742}$ eventually, the EU may come up with a common EU LCC method (or perhaps a common method for each product/service category) and it will be added to the Directive Annex, but it is unclear when this might occur, whether Member States would be required to use it, and what this methodology might be. However, Recital 20 of the revised 2019 Clean Vehicles Directive suggests that a standardized methodology may not be forthcoming nor will any LCC methodology become mandatory. ${ }^{743}$

While EU environmental law is a floor and not a ceiling, and does not prevent higher standards in terms on environmental protection, Sweden and other EU Member States cannot simply declare mandatory increased environmental standards for all products as trade is a harmonized area of law. This, ultimately, is the main rationale for EU- or nation-wide LCC standards to be incorporated into the public procurement process. Despite initial progress in GPP, there remains the question of who should have the larger role in fostering GPP - the EU itself or its Member States.

\footnotetext{
${ }^{741}$ See, e.g., Libby MacCarthy, 'Unilever, Google, Nestlé Join Forces to Transform Global Food Systems' (Sustainable Brands 19 Jan 2017) <http://www.sustainablebrands.com/news_and_views/collaboration/libby_maccarthy/unile-

ver_google_nest $1 \overline{\%} \mathrm{C} 3 \% \mathrm{~T}$ A 9 join_forces_transform_global_foo>; ' 25 leading global companies join together to accelerate transformational change in global food systems' (WBCSD 19 Jan 2017) <http://www.wbcsd.org/Overview/News-Insights/General/News/25-leading-globalcompanies-join-together-to-accelerate-transformational-change-in-global-food-systems $>$.

742 Public Sector Directive (n 8) Recital 96.

${ }^{743}$ Directive 2019/1161 of the European Parliament and of the Council of 20 June 2019, amending Directive 2009/33/EC on the promotion of clean and energy-efficient road transport vehicles.
} 
Fourth, due to the data and information intensity of life-cycle costing and true cost accounting, coupled with the need to convey this information to individual and institutional consumers, a merger of LCC information into more simplified eco-labels seems likely, allowing such third-party labels to be explicitly used in the public procurement process. This may result in EU public authorities requiring specific eco-labels (rather than only their technical criteria) and easing the link to the subject matter of the contract requirement, making it more flexible to allow inclusion of company level environmental policies. In the U.S., it may mean that private eco-labels will be at the forefront of life-cycle costing methods and informational distribution. While LCC may be incorporated into eco-labels, the information generated through the LCC process can also be incorporated and dictated by public law. LCC data may help us learn what processes cause the most significant environmental distress, suggesting that public environmental law can regulate these activities directly, and public law can dictate what data industry must generate.

Fifth, while neoliberalism is only a second-best solution, in the absence of direct regulation of product production (perhaps the best option), mandatory GPP requirements in public law through national/EU law in Europe and state/federal law in the U.S. will be necessary to make significant gains in private behavior. Mandatory GPP is necessary to lower the cost of environmentally friendly goods, reduce the informational burdens of GPP, and create standardized LCC methods and data transfer processes so states and municipalities can effectively engage in GPP.

Finally, while there is often a perceived conflict between economic development and the environment in many circles, future economic growth can and must be decoupled from environmental degradation if we are to achieve global sustainability. Here GPP plays a role, but only if nations begin to require GPP and increase production standards. The question remains how rigid a Member State can be in requiring certain LCC requirements for items to be sold domestically. "There has also been a lack of clarity regarding what right a Member State has to define its own level of environmental or health protection." ${ }^{\prime 44}$ EU Member States and American States should test the boundaries, under EU trade rules and U.S. Commerce Clause jurisprudence, of requiring GPP and only allowing the sale of goods that meet certain LCC production standards. The EU might also increase general environmental standards for all durables and consumables within the EU, making them applicable to all Member States to ensure environmental sustainability in the life cycle of all products. The same could be said for the U.S., but the EU's founding documents provide a much better foundation for environmental protection compared to the U.S., which has passed very few environmental laws since the environmental legislation boom of the 1970s.

${ }^{744}$ Langlet (n 121) 81. 
This step further would require that Member States or the EU to mandate contracting authorities to purchase environmentally-friendly goods and services (or provide incentives to do so). There are implementation benefits to EU-wide standards, or, perhaps (relying on American notions of sovereignty and the "laboratory of democracy"), creating EU incentives for a race to the top for GPP. Unfortunately, the European Union seems opposed to mandatory requirements or quotas in respect to environmental procurement. But will the lack of mandatory obligations in the Public Sector Directive stifle any innovation? Mandatory GPP reform will need to come from the EU or its Member States to create market demand and define life-cycle costing methodologies for all product areas (or at least the most environmentally costly ones). Prior to that, however, the future of green public procurement lies with public and private implementing institutions and firms that will develop standards for eco-labels and life-cycle costing.

GPP provides a path to sustainability as LCC methodology will soon provide data for measuring the environmental externalities that can later be regulated by public environmental law. Following the growth of GPP, both public procurement, and later public environmental regulation, can then engage the concerns of social justice and economic inequality to achieve all three pillars of sustainability. Voluntary green public procurement is an important bridge to mandatory sustainable production and consumption. 


\section{Bibliography}

\subsection{Primary Sources}

\section{Cases}

\section{U.S. Cases (in alphabetical order)}

American Meat Institute v Leeman 102 California Reporter 3d 759 (Cal Ct App 2009) Baldwin v GAF Seelig Inc 294 US 511 (1935)

Bibb v Navajo Freight Lines 359 US 520 (1959)

C \& A Carbone Inc v Town of Clarkstown, NY 511 US 383 (1994)

Chemical Specialties Manufacturers Association Inc v Allenby 958 F 2d 941 (9th Cir 1992)

City of Philadelphia v New Jersey 437 US 617628 (1978)

Committee of Dental Amalgam Manufacturers \& Distributors v Stratton 92 F 3d 807 (9th Cir 1996)

Dean Milk Co v City of Madison Wisconsin 340 US 349 (1951)

Dowhal v Smithkline Beecham Consumer Healthcare 88 P 3d 1 (Cal 2004)

Exxon Corp v Maryland 437 US 117 (1978)

Felder v Casey 487 US 131 (1988)

Fidelity Federal Savings \& Loan Association v De la Cuesta 458 US 141 (1982)

Gade v National Solid Wastes Management Association 505 US 88 (1992)

Gibbons v Ogden 22 US 1 (1824)

Gonzales v Raich 545 US 1 (2005)

Granholm v Heald 544 US 460 (2005)

Hines v Davidowitz 312 US 52 (1941)

Hughes v Alexandria Scrap Corp 426 US 794 (1976)

Hunt v Washington State Apple Advertising Commission 432 US 333 (1977)

Kassel v Consolidated Freightways Corp 450 US 662 (1981)

Lewis v BT Investment Managers Inc 447 US 27 (1978)

Maine v Taylor 477 US 131 (1986)

Metropolitan Life Insurance Co v Ward 470 US 869 (1985)

Minnesota v Clover Leaf Creamery Co 449 US 456 (1981)

New State Ice Co v Liebmann 285 US 262 (1932)

People ex rel Lungren v Cotter \& Co. 62 Cal Rptr 2d 368 (Cal Ct App 1997)

Perez v Campbell 402 US 637 (1971)

Pierce County Washington v Guillen 537 US 129 (2003)

Pike v Bruce Church Inc 397 US 137 (1970)

Reeves Inc v Stake 447 US 429 (1980)

Rice v Santa Fe Elevator Corp 331 US 218 (1947)

Shaw v Delta Air Lines Inc 463 US 85 (1983)

Smith Setzer \& Sons Inc v South Carolina Procurement Review Panel 20 F 3d 1311 (4th Cir 1994) 
South-Central Timber Development Inc v Wunnicke 467 US 82 (1984)

United Haulers Association Inc v Oneida-Herkimer Solid Waste Management Authority 550 US 330 (2007)

US v Lopez 514 US 549 (1995)

US v Morrison 529 US 598 (2000)

White v Massachusetts Council of Construction Employers Inc 460 US 204 (1983)

Wickard v Filburn 317 US 111 (1942)

\section{EU Cases (in chronological order)}

Case 26/62 Van Gen den Loos v Nederlandse Administratie Der Belastingen [1963] ECR 1

Case 6/64 Costa v ENEL [1964] ECR 585

Case 41/74 van Duyn v Home Office [1974] ECR 1337

Case 120/78 Rewe-Zental AG (Cassis de Dijon) [1979] ECR 649

Case 148/78 Pubblico Minsistero v Tullio Ratti [1979] ECR 1629

Case C-302/86 Commission v Denmark [1988] ECR 4607

Case C-106/89 Marleasing SA v La Commercial Internacionale de Alimentacion SA [1990] ECR I-4135

Joined Cases C-6/90 and C-9/90 Francovich and Bonifaci v Italian Republic [1991] ECR I-5357

Case C-55/94 Gebhard v Consiglio dell'Ordine degli Avvocati e Procuratori di Milano [1995] ECR I-4165

Joined Cases C-46/93 and C-48/93 Brasserie du Pêcheur/Factorame [1996] ECR I5357

Case C-324/98 Telaustria and Telefonadress [2000] ECR I-10745

Case C-59/00 Vestergaard [2001] ECR I-9505

Case C-513/99 Concordia Bus Finland Oy Ab v Helsingin Kaupunki et HKL-Bussiliikenne [2002] ECR I-7213

Case C-448/01 EVN AG and Wienstrom GmbH v. Republik Österreich [2003] ECR $\mathrm{I}-14527$

Case C-111/03 Commission v Sweden [2005] ECR I-8789

Case C-264/03 Commission v France [2005] ECR I-8831

Case C-234/03, Contse et al v Ingesa [2005] ECR I-9315

Case C-6/05 Medipac-Kazantzidis [2007] ECR I-4557

Case C-489/06 Commission v Greece EU:C:2009:165

Case C-368/10 Commission v Netherlands [2012] ECR I-000

Case C-573/12 Ålands Vindkraft AB v Energimyndigheten EU:C:2014:37

Case C-296/15 Medisanus EU:C:2017:431

\section{Statutory and Administrative Law Instruments (in order by citation date)}

\section{U.S. Instruments}

US Const art I

US Const art VI

US Const amend $\mathrm{X}$

Ala Code $\S 41-16-57$ (1975)

Pennsylvania Reciprocal Limitations Act, 62 PA Const Stat Ann $§ 107$ (West 1986) 
New York State Omnibus Procurement Act (1994) (codified as amended at 1994 NY Laws 3553 and 2000 NY Laws 3032)

Exec Order No 13,101, Greening the Government Through Waste Prevention, Recycling, and Federal Acquisition, 63 Fed Reg 49,643 (Sept 9, 1998)

Exec Order No 13,148, Greening the Government through Government Leadership in Environmental Management (Apr 21, 2000)

Colo Rev Stat § 8-18-103 (2003)

La Rev Stat $\S 38: 2251(2005)$

42 USC $\S 9621(\mathrm{e})(1)(2006)$

Haw Rev Stat $\S 103$ D-1002(a) (2006)

Exec Order No 13,423, Strengthening Federal Environmental, Energy, and Transportation Management, 72 Fed Reg 3,919 (Jan 26, 2007)

New York State, Exec Order No 4 (2008), Establishing a State Green Procurement and Agency Sustainability Program, https://www.dec.ny.gov/energy/71389.html

NY Comp Codes R \& Regs title 9, § 7.4 (2008)

Exec Order No 13,514, Federal Leadership in Environmental, Energy, and Economic Performance, 74 Fed Reg 194 (Oct 8, 2009)

HB 2763, 75th Legis Assem Reg Sess (Or 2009)

Local Foods, Farms, and Jobs Act, 30 Ill Comp Stat 595/10 (2009)

Brookhaven, NY, Code ch 7B: Green Procurements (2009)

Office of the Mayor, City and County of San Francisco, Executive Directive 09-03 (Jul 9, 2009), Healthy and Sustainable Foods for San Francisco, http://civileats.com/wp-content/uploads/2009/07/Mayor-Newsom-Executive-Directiveon-Healthy-Sustainable-Food.pdf

National Environmental Policy Act, 42 USC § 1332 (2012)

Okla Admin Code § 260:85-1-4 (2014)

Green Chemistry Procurement Guidelines, Or Rev Stat § 279A.140, 279B.205, 184.423(1)(j) (Sept 10, 2014)

Exec Order No 13,693, Planning for Federal Sustainability in the Next Decade, 80 Fed Reg 15,871 (Mar 25, 2015)

FAR $\S 23.103-104$ (Nov 12, 2015)

FAR $\S 23.400$ (Nov 12, 2015)

FAR $\S 23.404$ (b) (Nov 12, 2015)

Suwanee, GA, Code of Ordinances $\S 34-512$ (2016)

Sterling, Colo Code art IV, §19-235 (2017)

Hartford, Conn, Code $\S 2-548$ (2017)

Indian Head, Md, Ordinances No. 06-01-17, art III, § 3-22 (2017)

Iowa Code $\$ 8$ A.317 (2017)

31 USC $\S 3552$ (Protests by interested parties concerning procurement actions) (2018)

Clean Air Act, 42 USC $\S 7409$ (b)(1) (National primary and secondary ambient air quality standards) (2018)

Colo Code Regs $\S 101-9$ (2018)

19-4000-4000 Del Code Regs (2018)

19-4106 Del Code Regs (2018)

Duvall, Wash, Code of Ordinances $§ 3.12 .010$ (2018)

Life-Cycle Cost Methodology, 10 CFR § 455.64(a)(c) (2019)

Cal Pub Cont Code $\S 12400-12404$ (2019)

Cal Health \& Safety Code $\S \S 25249.5-25249.13$ (2019)

NYC Admin Code $\S \S 6-306$ (2019)

Or Admin R 125-247-0170 (2019)

Or Admin R 731-147-0020 (2019) 


\section{EU and Member State Instruments}

Council Directive 2004/18/EC [2004] OJ L134/129

Förordning (2009:907) om miljöledning i statliga myndigheter, $13 \S$

Consolidated Version of the Treaty on European Union and the Treaty on the Functioning of the European Union [2010] OJ C83

Directive 2014/23/EU of the European Parliament and of the Council of 26 February 2014 on the Award of Concession Contracts [2014] OJ L94

Directive 2014/24/EU of the European Parliament and of the Council of 26 February 2014 on Public Procurement and Repealing Directive 2004/18/EC [2014] OJ L94/65

Directive 2014/25/EU of the European Parliament and of the Council of 26 February 2014 on Procurement by Entities Operating in the Water, Energy, Transport and Postal Services Sectors and Repealing Directive 2004/17/EC [2014] OJ L94/23

SOU 2014:51, Ch 9 pp 294-299

Public Contracts Regulations 2015, SI 2015/102

Environment in the new Swedish Act on Public Procurement (2016:1145), 4 kap. 3 §

Directive 2019/1161 of the European Parliament and of the Council of 20 June 2019, amending Directive 2009/33/EC on the promotion of clean and energy-efficient road transport vehicles

\section{Other Materials (in order by citation date)}

US Environmental Protection Agency, 'A Study of State and Local Government Procurement Practices that Consider Environmental Performance of Goods and Services' (1996)

Commission, 'Public Procurement in the European Union, Guide to the Community Rules on Public Procurement of Services Other Than in the Water, Energy, Transport and Telecommunications Sectors, Directive 92/50/EEC 5' (1997)

Stockholm Convention on Persistent Organic Pollutants [2001]

National Risk Management Research Laboratory, Office of Research and Development, US Environmental Protection Agency, Life Cycle Assessment: Principles and Practice, EPA/600/R-06/060 (May 2006)

Woodbury County, Iowa, Policy for Rural Economic Revitalization: Local Food Policy $(2006)<$ http://www.iatp.org/files/258_2_96615.pdf $>$

Commission, 'Buying Social: A Guide to taking account of social Considerations in Public Procurement' (2010)

Fischer E, 'Green Procurement: Overview and Issues for Congress' (Congressional Research Service, 20 Apr 2010) <https:/www.epa.gov/sites/production/files/2015-09/documents/green_procurement_-_overview_and_issues_for_congress.pdf>

Commission, 'Green Paper on the Modernisation of the EU Public Procurement Policy: Towards a More Efficient European Procurement Market' (2011)

Commission, 'Proposal for a Directive of the European Parliament and of the Council on Public Procurement' COM/2011/0896

Greenhouse Gas Protocol, 'Product Life Cycle Accounting and Reporting Standards' (2011) < http://www.ghgprotocol.org/sites/default/files/ghgp/standards/ProductLife-Cycle-Accounting-Reporting-Standard_041613.pdf $>$

Commission, 'JRC Conference Reports, The International Reference Life Cycle Date System (ILCD) Handbook’ (2012) <http://eplca.jrc.ec.europa.eu/uploads/JRC- 
Reference-Report-ILCD-Handbook-Towards-more-sustainable-production-andconsumption-for-a-resource-efficient-Europe.pdf>

Halchin E, 'Overview of the Federal Procurement Process and Resources' (Congressional Research Service 2012) <https:/fas.org/sgp/crs/misc/RS22536.pdf>

US Environmental Protection Agency, 'Draft Guidelines: Product Environmental Performance Standards and Ecolabels for Voluntary Use in Federal Procurement (Nov 2013) <https://www.regulations.gov/document?D=EPA-HQ-OPPT-20130579-0001>

Commission, 'New Rules on Public Contracts and Concessions: Simpler and More Flexible' (2014)

Commission, 'Public Procurement Reform Factsheet No. 7: Green Public Procurement' (2014) <https://ec.europa.eu/docsroom/documents/15509/attachments/1/translations/en/renditions/native $>$

Commission, 'Revision of Public Procurement Directives - Frequently Asked Questions, Memo/14/20' (15 Jan 2014)

Government UK, 'Greening Government Commitment Targets' (8 Aug 2014) $<$ https://www.gov.uk/government/publications/greening-government-commitments-targets/greening-government-commitment-targets $>$

Government UK, 'Sustainable Procurement Tools' (2 Sept 2014) $<$ https://www.gov.uk/guidance/sustainable-procurement-tools $>$

US Environmental Protection Agency, 'Draft Guidelines for Product Environmental Performance Standards and Ecolabels for Use in Federal Procurement' (Dec 2014) <http://www2.epa.gov/sites/production/files/2015-09/documents/draftguidelines_i_-_iii_-_iv_-_nov2013_and_revised_ii_-_dec2014.pdf $>$

State of New Jersey, 'Tag Policy Letter 15-1, NJARNG Energy and Water Conservation Policy' (15 May 2015)

Government Offices of Sweden, 'Public Procurement - How it Works in Sweden' (12 Feb 2015) <http://www.government.se/government-policy/central-governmentadminstration/public-procurement---how-it-works-in-sweden/>

US Environmental Protection Agency, 'State and Local Government Pioneers: How State and Local Governments are Implementing Environmentally Preferable Purchasing Practices' (2015) < https://www.epa.gov/sites/production/files/201505/documents/statenlocal.pdf>

Commission, 'Buying Green! A Handbook on Green Public Procurement' (3rd edn, 2016)

Commission, 'Networks and Initiatives'<http://ec.europa.eu/environment/gpp/initiatives_en.htm $>$ accessed 6 Aug 2016

US Environmental Protection Agency, 'EPA Environmentally Preferable Purchasing Program Pilot to Assess Standards and Ecolabels for EPA's Recommendations to Federal Agencies: Final PILOT Assessment Guidelines' (Dec 2016)

Eur Parliament, Diretorate-General for Internal Policies (provided by Policy Dept A at the request of the Committee on the Environment, Public Health and Food Safety), 'Green Public Procurement and the EU Action Plan for the Circular Economy' (May 2017)

Global Affairs Canada, 'European Union Government Procurement Guide for Canadian Businesses' (2017) <http://www.international.gc.ca/gac-amc/assets/pdfs/publications/European-Union-Government-Procurement-GuideENG.pdf $>$

Commission, Development of a weighting approach for the Environmental Footprint (JRC Technical Reports 2018)

Commission, 'EU Emissions Trading System (EU ETS)' <http://ec.europa.eu/clima/policies/ets/index_en.htm> accessed Apr 16, 2018 
Commission, 'Green Public Procurement' < http://ec.europa.eu/environment/gpp/index_en.htm> accessed 16 Apr 2018

Commission, 'Persistent Organic Pollutants (POPs)' <http:/ec.europa.eu/environment/chemicals/international_conventions/index_en.htm $>$ accessed 16 Apr 16 2018

Commission, 'Public Procurement' <https://ec.europa.eu/growth/single-market/public-procurement_en> accessed 17 Apr 2018

Commission, 'Public Procurement: Legal Rules and Implementation' $<$ https://ec.europa.eu/growth/single-market/public-procurement/rules-implementation_en $>$ accessed 17 Apr 2018

LCC Public Procurement Tool, 'Calculating Your Real Costs' < http://tool.smartspp.eu/> accessed 17 Apr 2018

Commission, EU Eco-label $<$ http://ec.europa.eu/environment/ecolabel/> accessed 18 Apr 2018

Commission, 'Legal Rules and Implementation' <https://ec.europa.eu/growth/singlemarket/public-procurement/rules-implementation_en> accessed 18 Apr 2018

Commission, 'Life-Cycle Costing' <http://ec.europa.eu/environment/gpp/lcc.htm> accessed 18 Apr 2018

Energy Star, <http://www.energystar.gov/> accessed 18 Apr 2018

Massachusetts Executive Office for Administration and Finance, 'Learn About EPPs and the EPP Purchasing Program' <http://www.mass.gov/anf/budget-taxes-andprocurement/procurement-info-and-res/procurement-prog-and-serv/epp-procurement-prog/learn-about-epps/\#EO_515> accessed 18 Apr 2018

US Environmental Protection Agency, 'Guidelines for the Assessment of Environmental Performance Standards and Ecolables for Federal Procurement' $<$ http://www2.epa.gov/greenerproducts/draft-guidelines-product-environmentalperformance-standards-and-ecolabels-voluntary> accessed 18 Apr 2018

US Environmental Protection Agency, 'Recommendations of Specifications, Standards, and Ecolabels for Federal Purchasing' <https://www.epa.gov/greenerproducts/epas-recommendations-specifications-standards-and-ecolabels-federal-purchasing > accessed 18 Apr 2018

US Environmental Protection Agency, 'WaterSense' < https://www.epa.gov/watersense> accessed 18 Apr 2018

US Dept of Justice, 'Sole Source Justification' <https://ojp.gov/training/pdfs/SoleSource-FactSheet-C.pdf> accessed 16 Jul 2018

US Army Corps of Engineers, 'Federal Facilities Environmental Stewardship and Compliance Assistance Center' <https://www.fedcenter.gov/programs/buygreen> updated 29 May 2019

Commission, 'Buy Smart+ Green Procurement in Europe (BUY SMART+)' $<$ https://ec.europa.eu/energy/intelligent/projects/en/projects/buy-smart-0> accessed 29 Jul 2019

Federal Deposit Insurance Corporation, 'DIC OMWI Education Module: Understanding the Government Solicitation Bid Package' <https://www.fdic.gov/about/diversity/sbrp/52.doc > accessed 29 Jul 2019

The National Agency for Public Procurement, 'Indoor Lighting' <http://www.upphandlingsmyndigheten.se/en/sustainable-public-procurement/sustainable-procurement-criteria/building-and-property/indoor-lighting/light-sources-and-luminaires/lcc-lifecycle-cost-calculation-for-light-sources/> accessed 29 Jul 2019

The National Agency for Public Procurement, 'Life Cycle Cost Calculation - Professional Refrigerators and Freezers' <http://www.upphandlingsmyndigheten.se/en/sustainable-public-procurement/sustainable-procurement-criteria/building-and-property/professional-kitchen/professional-refrigerators-and- 
freezers/life-cycle-cost-calculation---professional-refrigerators-and-freezers/> accessed 29 Jul 2019

The National Agency for Public Procurement, 'The Lighting System's Life Cycle Cost' <http:/www.upphandlingsmyndigheten.se/en/sustainable-public-procurement/sustainable-procurement-criteria/building-and-property/outdoor-lighting/lighting-design/the-lighting-systems-life-cycle-cost-lcc/> accessed $29 \mathrm{Jul}$ 2019

The National Agency for Public Procurement, 'LCC' $<$ http://www.upphandlingsmyndigheten.se/en/sustainable-public-procurement/sustainable-procurement-criteria/building-and-property/household-appliances/washing-machines/lcc/> accessed 29 Jul 2019

The National Agency for Public Procurement, 'Life Cycle Costing (LCC)' $<\mathrm{http}$ ://www.upphandlingsmyndigheten.se/en/sustainable-public-procure$\mathrm{ment} /$ sustainable-procurement-criteria/vehicles-and-transport/vehicles/privatecars/life-cycle-costing-lcc/> accessed 29 Jul 2019

The National Agency for Public Procurement, 'Requirements on Products' $<$ https://www.upphandlingsmyndigheten.se/en/sustainable-public-procurement/sustainable-procurement-criteria/imposing-environmental-requirementsthe-right-way/requirements-on-products/> accessed 29 Jul 2019

The National Agency for Public Procurement, 'Sustainability Criteria' $<\mathrm{http}$ //www.upphandlingsmyndigheten.se/en/sustainable-public-procurement/sustainable-procurement-criteria/> accessed 29 Jul 2019

US General Services Administration and US Dept of Energy, Verification Guide for Federal Purchasers of Sustainable Products (unknown date)

Government Offices of Sweden, Ministry of Finance, 'National Public Procurement Strategy' $<$ https://www.upphandlingsmyndigheten.se/globalassets/english/procurement/national_public_procurement_strategy_english_web.pdf $>$

\subsection{Secondary Sources (in alphabetical order)}

Ackerman A, 'Buy Healthy, Buy Local: An Analysis of Potential Legal Challenges to State and Local Government Local Purchase Preferences' (Fall 2011) 43 The Urban Lawyer 1015

Adams A, 'It's Getting Hot in Herre: California Senate Bill 1368 and the Dormant Commerce Clause' (2011) 1 San Diego J Climate and Energy L 287

Anderson T and Leal D, Free Market Environmentalsim (rev edn, Palgrave Macmillan 2001)

Andhov M, 'Contracting authorities and strategic goals of public procurement - a relationship defined by discretion?' in Sanja Bogojević, Xavier Groussot, Jörgen Hettne (eds) Discretion in EU Procurement Law (Hart 2019)

Arrowsmith S, 'Introduction to the EU' in Arrowsmith S (ed), EU Public Procurement Law: An Introduction (2010)

Arrowsmith S, The Law of Public and Utilities Procurement (3rd edn, vol 1, Street \& Maxwell 2014)

Arrowsmith S, 'The Public Sector Directive 2004/18: Scope of Coverage' in in Arrowsmith S (ed), EU Public Procurement Law: An Introduction (2010)

Arrowsmith S and Kunzlik P, Social and Environmental Policies in EC Procurement Law: New Directives and New Directions (Cambridge 2009) 
Avetisyan M, Hertel T and Sampson G, 'Is Local Food More Environmentally Friendly? The GHG Emissions Impacts of Consuming Imported versus Domestically Produced Food' (Environmental and Resources Economics Jul 2013) $<$ http://web.ics.purdue.edu/ hertel/data/uploads/publications/avetisyan-hertelsampson-food-miles.pdf>

Barnard C and Peers S, European Union Law (2nd edn, Oxford 2017)

Beery M and Vallianatos M, Center for Food Justice and Urban and Environmental Policy Institute, Farm to Hospital: Promoting Health and Supporting Local Agriculture (2004)

Bogojević S, Groussot X and Hettne J (eds), Discretion in EU Public Procurement Law (Hart 2019)

Bovis C, EU Public Procurement Law (Edward Elgar 2007)

Braaten D and Coit M, 'Legal Issues in Local Food Systems' (2010) 15 Drake J Agriculture $\mathrm{L} 9$

Bugge H and Voigt C, Sustainable Development in International and National Law (Europa Law Publishing 2008)

Burg R, 'The Role of the U.S. Court of Appeals for the Federal Circuit in Government Contract Disputes: A Historic View from the Bench' (2012) 42 Public Contract LJ 173

Caithness A, 'What is a Prior Information Notice (PIN)?' (LinkedIn 10 Mar 2015) $<$ https://www.linkedin.com/pulse/what-prior-information-notice-pin-alastaircaithness/>

Caranta R, 'The Changes to the Public Contract Directives and the Story They Tell About How EU Law Works' (2015) 52 CML Rev 391

Caranta R, 'Labels as enablers of sustainable public procurement' in Sjåfjell B and Wiesbrock A (eds), Sustainable Public Procurement Under EU Law: New Perspectives as Stakeholder (Cambridge 2016)

Caranta R and Trybus (eds), The Law of Green and Social Procurement in Europe (DJØF Publishing Copenhagen 2010)

Caranta R, On Jörgen Hettne's Legal Analysis of the Possibilities of Imposing Requirements in Public Procurement that Go beyond the Requirements of EU Law (2013)

Center for Eur Policy Studies and Council of Eur, The Uptake of Green Public Procurement in the EU27 (2012)

Chemerinsky E, Constitutional Law: Principles and Policies (Aspen 2006)

Cho R, 'How Green is Local Food?' (Earth Institute, Columbia University 4 Sept 4 2012) < http://blogs.ei.columbia.edu/2012/09/04/how-green-is-local-food/>

Clune W, 'A Comparative Law Analysis of the Use of State-Level Green Public Procurement in the European Union and the United States' (2011) 1 Nordic Environmental LJ 3

Coenen D, 'Untangling the Market-Participant Exemption to the Dormant Commerce Clause' (1989) 88 Michigan L Rev 395

Comba M, 'Green and Social Considerations in Public Procurement Contracts: A Comparative Approach' in Caranta R and Trybus M (eds), The Law of Green and Social Procurement in Europe (DJØF Publishing Copenhagen 2010)

Conway D, 'Sustainable Procurement Policies and Practices at the State and Local Government Level' in Hirokawa K and Salkin P (eds), Greening Local Government: Legal Strategies for Promoting Sustainability, Efficiency, and Fiscal Savings (ABA 2012)

Craig P and de Búrca G, EU Law: Text, Cases and Materials (6th edn, Oxford 2015)

Cryer R and others, Research Methodologies in EU and International Law (Hart 2011) 
Czarnezki J, Homan A and Jeans M, 'Creating Order Amidst Food Eco-Label Chaos' (2015) 25 Duke Environmental L and Policy Forum 281

Czarnezki J and Pollans M, Eco-labeling, in Oxford Handbook on Comparative Environmental Law (Oxford University Press 2018)

Czarnezki J, Everyday Environmentalism: Law, Nature and Individual Behavior (ELI 2013)

Czarnezki J, 'Food, Law \& the Environment: Informational and Structural Changes for a Sustainable Food System' (2011) 31 Utah Environmental L Rev 263

Czarnezki J and Fiedler K, 'The Neoliberal Turn in Environmental Regulation' (2016) Utah L Rev 1

Czarnezki J, 'New York City Rules! Regulatory Models for Environmental and Public Health' (2015) 66 Hastings LJ 1621

Czarnezki J and Ford W, 'The Phantom Philosophy? An Empirical Investigation of Legal Interpretation' (2006) 65 Maryland L Rev 841

Czarnezki J, 'States as Market Participants in the U.S. and the EU? Public Purchasing and the Environment' (2013) 2 Swedish Institute for Eur Policy Studies 1

Czarnezki J and Van Garsse S, 'What is Life Cycle Costing?' in Andhov M, Caranta R, Wiesbrock A (eds), Cost and EU Public Procurement Law: Life-Cycle Costing for Sustainability' (Routledge Publishing 2019)

Danneman G, 'Comparative Law: Study of Similarities or Differences?' in Reimann $\mathrm{M}$ and Zimmerman R (eds), The Oxford Handbook of Comparative Law (Oxford 2006)

Darpö J and Nilsson A, 'On the Comparison of Environmental Law' (2010) $3 \mathrm{~J}$ of Court Innovation 315

Darpö J, 'Article 9.2 of the Aarhus Convention and EU Law: Some Remarks on CJEUs Case-Law on Access to Justice in Environmental Decision-Making' (2014) 11 JPEL 367

Davies G, 'The Competence to Create an Internal Market: Conceptual Poverty and Unbalanced Interests' in Sacha Garben and Inge Govaere, The Division of Competences between the EU and the Member States (Hart 2017)

de Sadeleer N, EU Environmental Law and the Internal Market (Oxford 2014)

Denning B and others, 'Laws to Require Purchase of Locally Grown Food and Constitutional Limits on State and Local Government: Suggestions for Policymakers and Advocates' (2010) 1 J Agriculture, Food Systems, and Community Development 139

Dragos D and Neamtu B, 'Life-Cycle Costing for Sustainable Public Procurement in the European Union" in Sjåfjell B and Wiesbrock A (eds), Sustainable Public Procurement under EU Law: New Perspectives on the State as Stakeholder (Cambridge 2015)

Dragos D and Neamtu B, 'Sustainable Public Procurement in the EU: Experiences and Prospects' in Francois Lichère and others (eds), Modernising Public Procurement: The New Directive (DJØF Publishing 2014)

Dragos D and Neamtu B, 'Sustainable Public Procurement: Life Cycle Costing (LCC) in the New EU Directive Proposal' (2013) 1 EPPPL 19

Drelich D, 'Restoring the Cornerstone of the Clean Water Act' (2009) 34 Columbia J Environmental L 267

Driesen D, Adler R and Engel K, Environmental Law: A Conceptual and Pragmatic Approach (Aspen 2011)

Eberle E, 'The Method and Role of Comparative Law' (2009) 8 Washington U Global Studies L Rev 451

Editorial, 'Public Procurement as Economic or Policy Exercise' 3 EPPPL (2017) 
Edman $\ddot{A}$ and Nohrstedt P, 'Sweden No Socially Responsible Public Procurement without Monitoring the Contract Conditions' (2017) 3 EPPL 352

Ekroos A, EC Legislation on Public Procurement and Sustainable Development, in Bugge $\mathrm{H}$ and Voigt C (eds), Sustainable Development in International and $\mathrm{Na}$ tional Law (Europa Law Publishing 2008)

Eskridge, Jr W, Dynamic Statutory Interpretation (Harvard 1994)

Farber D, 'Legal Guidelines for Cooperation Between the EU and American State Governments' in Vogel D and Swinnen J (eds), Transatlantic Regulatory Cooperation: The Shifting Roles of the EU, the U.S. and California (2011)

Fejø J, 'Social and Environmental Policies in EU Public Procurement Law' in Arrowsmith S (ed), EU Public Procurement Law: An Introduction (2010)

Feldman S and Keyes W, Government Contracts in a Nutshell (5th edn, West Academic Publishing 2011)

Fiedler K, Lord S and Czarnezki J, 'Life Cycle Costing and Food Systems: Concepts, Trends, and Challenges of Impact Valuation’ (2018) 8 Michigan J of Administrative and Environmental L 1

Foodlinks, Revaluing Public Sector Food Procurement in Europe: An Action Plan for Sustainability (2013) <http://www.foodlinkscommunity.net/fileadmin/documents_organicresearch/foodlinks/publications/Foodlinks_report_low.pdf $>$

Food Tank, The Real Cost of Food: Examining the Social, Environmental, and Health Impacts of Producing Food (2015)

Foreword, 3 EPPPL (2017)

Gesser A, 'Canada's Environmental Choice Program: A Model for a "Trade-Friendly" Eco-Labeling Scheme' (1998) 39 Harvard Intl LJ 501

Hesterman O, Fair Food (PublicAffairs 2011)

Hettne J, 'Legal Analysis of the Possibilities of Imposing Requirements in Public Procurement that Go Beyond the Requirements of EU Law' (2013) 6 Upphandlingsutredningen

Hettne J, 'Strategic Use of Public Procurement - Limits and Opportunities' (2013) 7 SIEPS 1

Impact Valuation Roundtable, 'Operationalizing Impact Valuation: Experiences and Recommendations by Participants of the Impact Valuation Roundtable, White Paper' (2017) <https://www.basf.com/documents/corp/en/sustainability/management-and-instruments/quantifying-sustainability/we-create-value/IVR_Impact_Valuation_White_Paper_2017.pdf $>$

International Organization for Standardization 14007, Environmental Management: Determining Environmental Costs and Benefits - Guidance

International Organization for Standardization 14008, Monetary Valuation of Environmental Impacts and Related Environmental Aspects

International Organization for Standardization 14024, Environmental Labels and Declarations - Type I Environmental Labelling - Principles and Procedures

International Organization for Standardization 14044, Environmental Management Life Cycle Assessment - Requirements and Guidelines

International Union for Conservation of Nature, 'Governance and MEAs' $<$ https://www.iucn.org/theme/environmental-law/our-work/governance-andmeas $>$ accessed 29 Jul 2019

Jans J and Vedder H, European Environmental Law: After Lisbon (4th edn, 2012)

Jimmie VR and Castellano N, 'Successful Advocacy in Government Contracts Appeals Before The Federal Circuit: Context is Key' (2016) 46 Public Contract LJ 209

Johnson D and Burnette R, 'New Policies on Sustainable Acquisition: Among Last Proposed FAR Rules of Obama Administration' (The National $R 7$ Feb 2017) 
$<$ http://www.natlawreview.com/article/new-policies-sustainable-acquisitionamong-last-proposed-far-rules-obama>

Kahlenborn and others, Strategic Use of Public Procurement in Europe, Final Report to the European Commission MARKT/2010/02/C vi-vii (2011)

Kayden J, 'Market-Based Regulatory Approaches: A Comparative Discussion of Environmental and Land Use Techniques in the United States' (1992) 19 Boston College Environmental Affairs L Rev 565

Kesan J and Shah R, 'Shaping Code' (2005) 18 Harvard JL and Technology 319

King N and King B, 'Creating Incentives for Sustainable Buildings: A Comparative Law Approach Featuring the United States and the European Union' (2005) 23 Virginia Environmental LJ 397

Kunzlik P, 'Comment on Professor Jörgen Hettne's Paper, "Legal Analysis of the Possibilities of Imposing Requirements in Public Procurement that Go beyond the Requirements of EU Law, " and Professor Roberto Caranta's Commentary in Annex 12 to the Official Report of the Swedish Government 2013:12, "Goda affärer - en strategi för hållbar offentlig upphandling” (SOU 2013:12)' $<$ https://www.regeringen.se/49bb50/contentassets/94e3a7f86d2f4784b126e16c6f4ec3a4/bilagedel-3-sou-201312>

Langlet D and Mahmoudi S, Environmental Law and Policy (Oxford 2016).

Larner W, 'Neo-liberalism: Policy, Ideology, Governmentality' (2000) 63 Studies in Political Economy 5

Lazarus R, The Making of Environmental Law (Chicago 2004)

Lessig L, Code 2.0 (2d ed, CreateSpace 2009)

Lessig L, 'The New Chicago School' (1998) 27 J Legal Studies 661

Lexicon of Sustainability, 'True Cost Accounting: The Real Cost of Cheap Food' (Feb 2014) <http://www.pbs.org/food/features/lexicon-of-sustainability-true-cost-accounting-the-real-cost-of-cheap-food/> accessed 7 Mar 2019

Light S and Orts E, 'Parallels in Public and Private Environmental Governance' (2015) 5 Michigan J Environmental and Administrative L 1

Light S and Orts E, Public and Private Procurement in Environmental Governance, in Richards K and Van Zeben J (eds), Encyclopedia of Environmental Law [Policy Instruments in Environmental Law] (Edward Elgar 2017)

MacCarthy L, 'Unilever, Google, Nestlé Join Forces to Transform Global Food Systems' (Sustainable Brands 19 Jan 2017) <http://www.sustainablebrands.com/news_and_views/collaboration/libby_maccarthy/unilever_google_nestl $\% \mathrm{C} 3 \% \mathrm{~A} 9$ join_forces_transform_global_foo $>$

Manheim K, 'New-Age Federalism \& Market Participant Doctrine' (1990) 22 Arizona State LJ 559

McCrudden C, Buying Social Justice: Equality, Government Procurement, and Legal Change (Oxford 2007)

McGinnis J and Somin I, 'Federalism vs. States' Rights: A Defense of Judicial Review in a Federal System' (2004) 99 Northwestern U L Rev 89

McPartland J, 'EPA rolls out its redesigned labels under the newly minted Safer Choice Program' (Environmental Defense Fund 4 Mar 2015) $<$ http://blogs.edf.org/health/2015/03/04/epa-rolls-out-its-redesigned-labels-under-the-newly-minted-safer-choice-program/>

Merryman J, The Civil Law Tradition (3d ed, Stanford 2007)

Morris J, Green Goods?: Consumers, Product Labels and the Environment (IEA 1997)

Nash, Jr R, O'Brien-Debakey K and Schooner S, The Government Contracts Reference Book: A Comprehensive Guide to the Language of Procurement (4th edn, $\mathrm{CCH} 2013$ ) 
National Association of State Procurement Officials (NASPO), Executive Summary, NASPO 2009 Survey of State Government Purchasing Practices Survey Questions (2009)

National Association of State Procurement Officials, 'States with Green Purchasing Profiles' < http://www.naspo.org/dnn/greenmap/California.aspx $>$ accessed 29 Jul 2019

The National Association of State Procurement Officials (NASPO), '2019 Survey of State Procurement Practices' <https://www.naspo.org/Portals/16/2018\%20Survey/2018\%20FINAL\%20Survey\%20Report_6-14-18.pdf?ver=2018-06-14080105-470> accessed 29 Jul 2019

National Priorities Project, 'Federal Spending: Where Does the Money Go' $<$ https://www.nationalpriorities.org/budget-basics/federal-budget-101/spending/> accessed 17 Apr 2018

National Research Council, Sustainability Considerations for Procurement Tools and Capabilities: Summary of a Workshop (2012)

Natural Capital Coalition, 'Natural Capital Protocol' (2016) <http://naturalcapitalcoalition.org/protocol/>

Nilsson A, Enforcing Environmental Responsibilities: A Comparative Study of Environmental Administrative Law (Uppsala 2011)

Nordlund A and Garvill J, 'Effects of Values, Problem Awareness, and Personal Norm on Willingness to Reduce Personal Car Use' (2003) 23 J Environmental Psychology 339

Norris T, 'Consumer Litigation and FDA-Regulated Products: The Unique State of California' (2006) 61 Food and Drug LJ 547

Nowag J, 'Article 11 TFEU and Environmental Rights' in Bogojević S and Reyfuse R, Environmental Rights in Europe and Beyond (Hart 2018)

Oderkirk M, The Need for a Methodological Framework for Comparative Legal Research (2015) 70 Rabels Zeitschrift für ausländisches und internationales Privatrecht 589

Okubo A, 'Environmental Labeling Programs and the GATT/WTO Regime' (1999) 11 Georgetown Intl Environmental L Rev 599

Oliver P, 'Book Review: EU Environmental Law and the Internal Market, by Nicolas de Sadeleer (2014)’ (2014) 51 CML Rev 1873

Organisation for Economic Cooperation and Development, The Environmental Performance of Public Procurement: Issues of Policy Coherence (2003)

Osei K, 'The Best of Both Worlds: Reciprocal Preference and Punitive Retaliation in Public Contracts' (2011) 40 Public Contract LJ 715

Percival R, 'Environmental Federalism: Historical Roots and Contemporary Models' (1995) 54 Maryland L Rev 1141

Plastow R, Neoliberalism in environmental governance: a paradoxical double movement? (University of Exeter 2010)

Posner R, 'The Present Situation in Legal Scholarship' (1980) 90 Yale LJ 1113

Posner R, The Problems of Jurisprudence (Havard 1990)

PSRF Mathijsen (ed), A Guide to European Union Law (9th edn, Street \& Maxwell 2007)

Radich O, 'Green Procurement Hits the Internet' (Dec 2011) $<$ https://www.ncmahq.org/docs/default-source/default-document-library/articles/cm1211---52-59>

Resolve, Pilot Testing EPA Guidelines for Environmental Performance Standards and Ecolabels $<$ www.resolv.org/site-guidelines/background-information-and-resources/> accessed 29 Jul 2019 
Romera B and Caranta R, 'EU Public Procurement Law: Purchasing Beyond Price in the Age of Climate Change' (2017) 3 EPPPL 281

Roux T, 'Judging the Quality of Legal Research: A Qualified Response to the Demand for Greater Methodological Rigour' (2014) 24 Legal Education R 177

Salzman J, 'Teaching Policy Instrument Choice in Environmental Law: The Five P's' (2013) 23 Duke Environmental L and Policy Forum 363

Samuel G, An Introduction to Comparative Law Theory and Method (Hart 2014)

Scalia A, A Matter of Interpretation: Federal Courts and the Law (Princeton 1997)

Schindler S, 'Architectural Exclusion: Discrimination and Segregation through Physical Design of the Built Environment' (2015) 124 Yale LJ 1934

Schooner S, 'The Future: Scrutinizing the Empirical Case for the Court of Federal Claims' (2003) 71 George Washington L Rev 714

Seamon R, Note, 'The Market Participant Test in Dormant Commerce Clause Analysis-Protecting Protectionism?' 1985 Duke LJ 697

Semple A, A Practical Guide to Public Procurement (1st edn, Oxford 2015)

Semple A, 'The link to the subject matter: A glass ceiling for sustainable public contracts?' in Sjåfjell B and Wiesbrock A (eds), Sustainable Public Procurement Under EU Law: New Perspectives as Stakeholder (Cambridge 2016)

Smith J and others, 'Balancing Competing Policy Demands: The Case of Sustainable Public Sector Food Procurement' (2015) 112 J of Cleaner Production 249

Staffin E, 'Trade Barrier or Trade Boon?: A Critical Evaluation of Environmental Labeling and Its Role in the "Greening" of World Trade' (1996) 21 Columbia J Environmental L 205

Stewart R, 'A New Generation of Environmental Regulation?' (2001) 29 Capital U L Rev 21

Sundstrand A and Ågren R, 'The implementation of Directive 2014/24/EU in Sweden: A Sanguine Approach' in Treumer S and Comba M (eds), Modernising Public Procurement: The Approach of EU Member States (Edward Elgar 2018)

Testa F and others, 'Drawbacks and Opportunities of Green Public Procurement: An Effective Tool for Sustainable Production' (2016) 112 J Cleaner Production 1893

Trybus M and Andrecka M, 'Favouring Small and Medium Sized Enterprises with Directive 2014/24' (2017) 3 EPPPL 224

United Nations Food and Agriculture Organization, 'Natural Capital Accounting' $<$ http://www.fao.org/nr/sustainability/natural-capital/en/> accessed 18 Apr 2018

United Nations Office for Project Services, A Guide to Environmental Labels for Procurement Practitioners of the United Nations System (2009)

Vandenbergh M and Gilligan J, Beyond Politics: The Private Governance Response to Climate Change (Cambridge University Press 2017)

Vandenbergh M, 'Private Environmental Governance' (2013) 99 Cornell L Rev 129

Verdeaux J, 'Public Procurement in the European Union and In the United States: A Comparative Study' (2003) 32 Public Contract LJ 713

'25 leading global companies join together to accelerate transformational change in global food systems' (WBCSD 19 Jan 2017) <http://www.wbcsd.org/Overview/News-Insights/General/News/25-leading-global-companies-join-togetherto-accelerate-transformational-change-in-global-food-systems $>$

Weatherill S, 'EU Law on Public Procurement: Internal Market Law Made Better' in Bogojević S, Groussot X and Hettne J (eds), Discretion in EU Public Procurement Law (Hart 2019)

Weiland P, Comment, 'Federal and State Preemption of Environmental Law: A Critical Analysis' (2000) 24 Harvard Environmental L Rev 237

Yang T and Percival R, 'The Emergence of Global Environmental Law' (2009) 36 Ecology L Q 615 
Yukins C, The U.S. Federal Procurement System; An Introduction (2017)

2020VET, 'Sole Source' <https://cdn.ymaws.com/www.wipp.org/resource/resmgr/gm5_podcasts_rev/Sole_Source.pdf $>$ accessed 15 Jul 2018 
